\title{
Transferring Water Management Knowledge
}

How actors, interaction and context influence the effectiveness of Dutch-funded projects in Romania

Joanne Vinke-de Kruijf

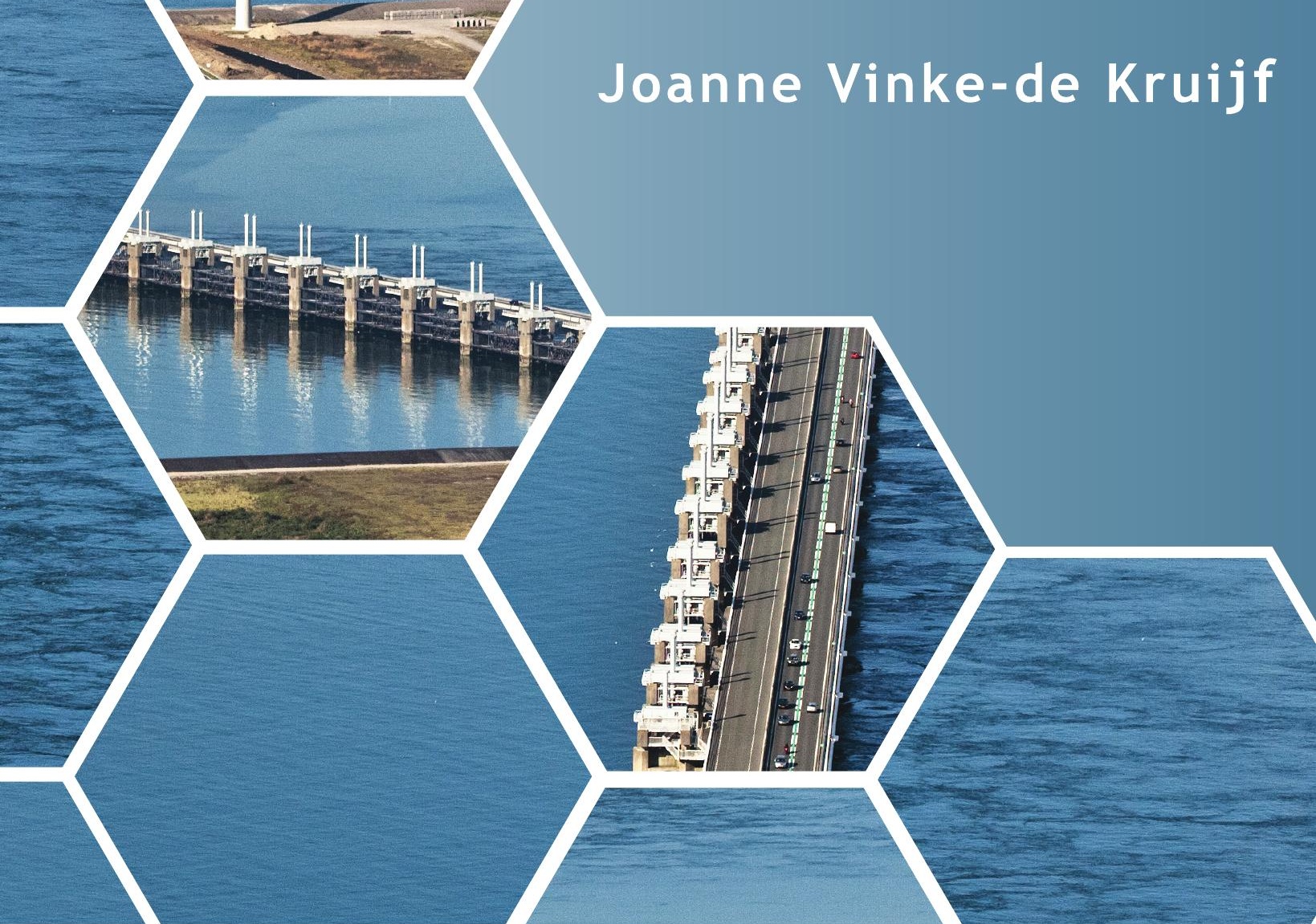




\title{
Transferring water management knowledge
}

\author{
How actors, interaction and context influence the \\ effectiveness of Dutch-funded projects in Romania
}

\author{
J oanne Vinke-de Kruijf
}

Enschede, the Netherlands, 2013

This thesis is a collaborative result of the Faculty of Engineering Technology, Department of Water Engineering and Management (www.utwente.nl/ctw/wem/) and the School of Management and Governance, CSTM: Twente Centre for Studies in Technology and Sustainable Development (www.utwente.nl $/ \mathrm{mb} / \mathrm{cstm} /$ ). The research was implemented with financial support of the Institute for Innovation and Governance Studies (www.utwente.nl/igs) and the Province of Overijssel. 
Graduation committee:

Chair, secretary: $\quad$ Prof. dr. F. Eising (University of Twente)

Promotors:

Prof. dr. S.J.M.H. Hulscher (University of Twente)

Prof. dr. J.T.A. Bressers (University of Twente)

Assistant promotor: $\quad$ Dr. ir. D.C.M. Augustijn (University of Twente)

Members:

Prof. dr. J.F.M. Koppenjan (Erasmus University)

Prof. dr. ing. S. Schaap (Delft University of Technology /

Wageningen University)

Prof. dr. ing. C. Teodosiu (“Gheorge Asachi” Technical

University of Iasi)

Prof. dr. A. van der Veen (University of Twente)

Em. Prof. dr. H.J. de Vriend (University of Twente)

Dr. V. Junjan (University of Twente)

Cover photo: (C) Frans Lemmens/Hollandse Hoogte (Oosterscheldekering / Eastern Scheldt storm surge barrier)

Cover design: Willemijn Krijnen \& Albers De Vries Communicatie

Printed by Wöhrmann Print Service, Zutphen

Copyright (C) 2013 by Joanne Vinke-de Kruijf, Enschede, the Netherlands

All rights reserved. No part of this publication may be produced, stored in a retrieval system, or transmitted, in any form or by any means, without the written permission of the author.

When referring to this dissertation, please consider using the following citation:

Vinke-de Kruijf, J. (2013), Transferring water management knowledge: How actors, interaction and context influence the effectiveness of Dutch-funded projects in Romania, PhD thesis, University of Twente, Enschede, the Netherlands. doi: $10.3990 / 1.9789036535397$

ISBN 978-90-365-3539-7

URL http://dx.doi.org/10.3990/1.9789036535397 


\title{
TRANSFERRING WATER MANAGEMENT KNOWLEDGE
}

HOW ACTORS, INTERACTION AND CONTEXT INFLUENCE THE EFFECTIVENESS OF DUTCH-FUNDED PROJECTS IN ROMANIA

\section{PROEFSCHRIFT}

ter verkrijging van

de graad van doctor aan de Universiteit Twente,

op gezag van de rector magnificus,

prof. Dr. H. Brinksma,

volgens besluit van het college voor promoties

in het openbaar te verdedigen

op woensdag 3 mei 2013 om 14:45 uur

\author{
door \\ Joanne Vinke-de Kruijf \\ geboren op 3 augustus 1983 \\ te Amersfoort
}


Dit proefschrift is goedgekeurd door:

Prof. dr. S.J.M.H. Hulscher (promotor)

Prof. dr. J.T.A. Bressers (promotor)

Dr. D.C.M. Augustijn (assistent promotor) 


\section{Preface}

The front cover of this thesis shows various parts of a photo of the Eastern Scheldt storm surge barrier. The photo was made by Frans Lemmens, a Dutch photographer who also made the book 'Icons of the Netherlands'. The Eastern Scheldt barrier is certainly one of these Dutch icons. This massive sea defense on the mouth of the Eastern Scheldt is one of the final parts of the Delta Works. This project was implemented in the Southwest of the Netherlands following the disastrous floods of 1953, when large parts of the country were inundated and more than 1,800 people lost their lives. Originally, the Eastern Scheldt barrier was planned to be a closed dam. However, protests by environmental movements resulted in a more flexible barrier. Large sections of the barrier are most of the time open and only closed off by gates when needed. Since its opening in 1987, the barrier has been a source of inspiration for other countries. The cities of London and St. Petersburg already followed this Dutch example, while Venice is also working on a similar system (Van der Tol, 2011).

Our struggle with water, how we survive in such a low-lying and densely populated country has long fascinated me. Since I started working on this research, I have developed a special fascination for the export of Dutch water management knowledge. Interesting is not only the eagerness with which we export water management knowledge, but also the high value that people in other countries attach to this knowledge. Over the past few years, and in particular during the three years that I lived in Romania, I have learnt a lot about the ins and outs of knowledge transfer projects. I have learnt about the diverse motivations of people to engage in such projects, how differently people perceive reality and how diverse their contributions can be. I have tried to understand what happens in these projects and why some are more successful than others. I hope this search has resulted in a dissertation that provides useful knowledge for scientists and practitioners involved in the analysis or implementation of knowledge transfer projects.

This dissertation marks the end of a five-year period during which I met many people who encouraged and supported me in my research. In this preface I would like to especially mention and thank some of these people. First of all, I want to thank the people who have been coaching and mentoring me. My two promotors, Suzanne Hulscher and Hans Bressers, and my daily supervisor, Denie Augustijn, have been a truly supportive team. 
Suzanne, without your enthusiasm and confidence in my skills and proposal, I would never ever have started and finished this $\mathrm{PhD}$. Hans, your great knowledge and experience in doing social sciences have been of great help. Denie, I still miss our weekly discussions too, via Skype when I was in Romania and face-to-face in the Netherlands. I also thank Valentina Dinica, who supervised me at the beginning of my research. Your scientific and Romanian backgrounds have been of great value. Furthermore, I thank Stefan Kuks for discussing the governance aspects of this thesis and for encouraging me.

Over the past few years, I have enjoyed the company of many colleagues and roommates, both at CSTM and at WEM. I thank all of you for your friendship and interest at work and at other occasions. Especially my collaboration with Cheryl de Boer and Gül Özerol (and with Hans Bressers) has been valuable and productive. I am proud that our edited book will be published soon and I am very happy that our collaboration still continues. Marlijn Baarveld, you have always been a very good friend, but our discussions on doing research have been nice too! Special thanks to Ada, Anke and Brigitte and the other secretaries of WEM and CSTM who were always there for supporting me. Furthermore, I want to thank the people of Haskoning Romania, with whom I shared an office for several years. In particular, I thank Ad Sannen for being my personal and professional coach and Mihaela Oproiu for showing me Romania. Also thanks to the students who contributed to this research: Oana Iacob, Bert Kort, Mark Cornelissen and Robin Peters.

I thank all those people who were involved in Dutch-Romanian projects and supported me in developing or implementing my research. The meetings of the user committee were always fruitful because of the positive contributions by Willem Tjebbe Oostenbrink, Dennis van Peppen, Job Udo, Leo Hendriks, Erik Ruijgh, Henk Loijenga, Ad Sannen and Bouke Ottow. Special thanks to Violeta Cozianu of the Dutch embassy for drinking coffees and to Carmen Teodosiu and many other persons of the "Gheorghe Asachi" Technical University in Iasi.

To have a big, loving and supportive family, next to so many friends, is a true blessing. There are too many of you to be mentioned separately, but I truly thank my parents, sisters and brothers (of my own and those in law) and friends for all encouragements, support and visits to Romania! My last words of thank are for my own little family. Barend, you have brought great joy to our lives and are an almost continuous source of laughter. Bernd, words fall short to thank you. I can imagine no better, more supportive or loving husband and father.

Joanne Vinke-de Kruijf

Enschede, 15 March 2013 


\section{Summary}

Many countries around the world face pressing water problems, including a high risk of flooding. The transfer of water management knowledge, from one country to another, can assist countries in solving these problems. Building on the experiences of Dutch-funded projects, this thesis questions the effectiveness of international knowledge transfer projects. It particularly builds on cases in which flood risk management knowledge is transferred from the Netherlands to Romania. Both European countries are located downstream of an international river basin. Their bilateral collaboration on environment and water dates back to 1995. Since then, the Netherlands has contributed to the implementation of hundreds of environmental projects in Romania. The two main reasons for giving supporting projects in Romania and other countries are to contribute to solving water problems and to strengthen the economic position of the Dutch water sector.

In this research, we see externally supported knowledge transfer projects as interactive processes through which actors of different countries share and acquire knowledge for the purpose of applying that knowledge. The central question reads: How do actors' motivations, cognitions, resources, their interactions and contextual factors shape the process and outcomes and influence the effectiveness of international water projects that involve a transfer of knowledge? This question is answered using the experiences of three Dutch-funded flood risk management projects that were implemented in Romania in the past few years. These cases are studied real-time using qualitative methods. As theoretical starting-point we use the Contextual Interaction Theory. This theory asserts that the course and outcomes of knowledge transfer projects are basically shaped by the key characteristics - i.e. the motivations, cognitions and resources - of actors involved. Contextual factors only influence a project in as far as they influence these actor characteristics. They are found in three layers: the project-specific context (such as, history and specific circumstances), the structural context (the so-called institutional or governance structure) and the wider context (including political, economic, socio-cultural, technological and problem contexts). In the various case studies, we complement this theory with insights from the literature on governance, evaluation, policy and knowledge transfer and social learning. The introductory chapter provides the background and focus, objective and questions, theoretical framework, research methodology and outline of the thesis. 
The structural context of the cases is the subject of Chapter 2. In this chapter, we assess Romania's flood risk governance structure. Floods represent the main natural risk in this country. They occur almost on a yearly basis, causing major economic damage and affecting many people. Our assessment of the governance structure builds on an existing model of governance, which we develop further using insights of the European Floods Directive. First, we describe the flood risk governance structure in terms of five dimensions: (1) levels and scales; (2) actors and network; (3) problem perspectives and goal ambitions; (4) strategies and instruments; and (5) responsibilities and resources. Next, we use the criteria of extent (i.e. the degree to which all uses and users are regulated) and coherence (i.e. the degree to which aspects are interconnected) to assess the supportiveness of this structure towards policy implementation. This assessment shows that new flood risk management strategies were adopted in response to an increase of flood risks and international policy developments. These new strategies acknowledge that more different aspects need to be included in flood risk management. However, the actual implementation of these 'best practices' is lagging behind. Participatory arrangements are often not functioning well, water managers are lacking resources, such as information and finances, and they continue to give preference to technical defence measures above more resilient measures. With the inclusion of more aspects into flood risk governance, the need for coherence also increased. Various measures were implemented to promote and support interactions among diverse actors. However, in practice, actors are hardly looking for synergy and integration. Thus, additional efforts are needed to increase both the extent and coherence of flood risk governance, in policies, but particularly in practice.

Chapter 3 presents a framework for the evaluation of the effectiveness of policy transfer projects. The framework is applied to the project 'Room for the River in Cat's bend, Romania'. In the framework, effectiveness is defined as the degree to which a project contributes to the intended or desired outcomes. Dutch-funded projects are effective when they contribute to solving water-related problems in the benefiting country and generate follow-up projects. These ultimate outcomes are often not yet visible at the end of a project, but can be predicted on the basis of the process and its immediate outcomes. A project is more likely to be effective when users (i.e. actors who have a crucial role in the implementation of the project or follow-up actions) are engaged in the process. User engagement can be measured through six process criteria: stakeholder involvement, institutional embedding, integration of context-specific knowledge, mutual understanding in communication, proactive diffusion strategy and adaptive management. We assess the development of a basis for further collaboration using four immediate outcome criteria: joint motivating goal, negotiated knowledge base, mobilization of resources and positive relational experiences (as a basis for trust). The case project concerns an interactive plan process that actively involved local and regional stakeholders. As a result, stakeholders developed a negotiated knowledge base about desired directions for solutions and became 
motivated to further elaborate these solutions. However, since actors with decision-making power were not involved in the project, they did not share this motivation and cognition. Hence, desired follow-up actions got stuck in a lack of resources. What explains these outcomes is the poor institutional embedding of the project alongside the lack of a proactive diffusion strategy and adaptive management. Given these immediate outcomes, the project is unlikely to result in the desired outcomes.

Chapter 4 provides an analysis on the role of actors, their knowledge and their interactions in an international knowledge transfer project. Using insights from the literature on knowledge management and technology and knowledge transfer, we investigate the project 'Pilot implementation of FLIWAS in Banat region, Romania'. FLIWAS is the acronym of an internet-based Flood Information and Warning System that assists flood risk managers by collecting, structuring and presenting relevant information. The case shows that knowledge transfer projects typically involve actors with diverse backgrounds and knowledge. Because of their diverse professional, organizational and socio-cultural backgrounds, actors sometimes experience difficulties in understanding each other, even though they speak the same language. To also communicate the 'tacit' aspects of knowledge, which are difficult to express in words or numbers, relatively more direct and intense interaction means and settings are often needed - although sometimes insufficient to bridge differences between actors. In the case, among others, active collaboration in teams and an interactive workshop enabling 'reflection-in-action' supported the transfer of knowledge. The case further demonstrates that projects tend to involve a wide variety of actors who have diverse levels of substantive knowledge. What benefits is the transfer of knowledge is the involvement of actors who have context-specific knowledge about the process and the network as well as actors who are good at developing and maintaining relations. Also, the involvement of actors with interactional knowledge (i.e. sufficient knowledge to translate between actors) about both country contexts is beneficial. Despite the involvement of actors with diverse capacities, the case was only partly successful. Actors became willing to initiate follow-up actions, but do not plan using the results of the pilot project.

In Chapter 5, we examine the nature and effects of learning in international knowledge transfer projects. We use insights from the literature on social learning - i.e. learning that occurs in interaction with others - to reflect on the project 'Integrated Water Management in the Tecucel River basin'. The case study shows that interactions contribute to relational and substantive learning. Learning changes the individual characteristics (i.e. the motivations, cognitions and resources) of actors involved. In addition, learning contributes to the development of collective outcomes (corresponding with the immediate outcomes introduced in Chapter 3) on which further collaboration can be based. In the case, both Dutch and Romanian actors learnt in the relational and the substantive domain. However, 
particularly the learning of most Dutch experts was not constructive implying that they became less motivated to continue their collaboration with their local counterparts. Local Romanian actors wanted to further collaborate. However, this is unlikely to happen since they cannot mobilize the financial resources for this. An important project result was that, on the basis of interactions in the periphery of the project, two Dutch actors decided to develop a partnership with a regional actor. The case demonstrates that a single international collaborative project can include multiple and diverse social learning processes. Whether learning forms a basis for further collaboration depends not only on 'how much' actors learn, but in particular on 'who learns what'.

Using the experiences of all three cases, we examine in Chapter 6 how contextual factors influence the characteristics of actors, and thus the effectiveness, of knowledge transfer projects. After introducing the general context of the cases, the chapter presents how the characteristics of actors involved changed as a result of the interactive processes. Subsequently, we reflect on two mechanisms through which contextual factors influence externally supported knowledge transfer projects. Firstly, we show that such projects involve actors with differing contextual backgrounds, and thus diverse motivations, cognitions and resources. These contextual differences complicate the transfer of knowledge and also form an incentive, and thus a source of motivation, for transferring knowledge. The cases demonstrate that particularly differences in cognitions and resources may seriously hamper the transfer of knowledge. Second, we reflect on the difficulty of embedding knowledge transfers in the context of the receiving country. The cases confirm that to adequately embed a project is challenging since the context is not easily influenced by a single project. However, the context is also far from stable and tends to change as a result of external developments. We conclude that the effectiveness of knowledge transfer projects particularly depends on the motivation and engagement of powerful actors in the process.

Chapter 7 compares the effectiveness of the three cases using the evaluation framework that is presented in Chapter 3. After explaining the main similarities and differences between the cases, we reflect on how they score on the various evaluation criteria. The cases have varying scores on the process and immediate outcome criteria. None of the projects scores high on the ultimate outcome criteria. Follow-up actions are needed to solve the addressed problems, but not planned for in any of the cases. Only in one case follow-up projects that potentially benefit the Dutch water sector are likely to be generated. We introduce a ratio scale to understand how the process and immediate outcomes are correlated with the ultimate outcomes. Particularly the correlation of the process with the immediate outcomes is strong for the studied cases. The process also correlates with the ultimate outcomes, but this relation is much weaker. These correlations are an interesting result since the criteria were never designed for being tested this way. Further qualitative reflections on the 
relations between the process and its outcomes show that particularly 'institutional embedding' is a strong explanatory factor. This criterion is closely connected to the adoption of a 'proactive diffusion strategy' and the 'integration of context-specific knowledge'. 'Adaptive management' is important, but difficult to achieve since projects are often too small and short to be adapted on the basis of relational and substantive learning. Furthermore, we found that in an international setting, special attention should always be given to the development of a 'mutual understanding in communication'. As regards the importance of 'stakeholder involvement', we found that this was an important component of the cases, but only becomes highly relevant when moving towards implementation. Regarding the immediate outcomes, we conclude that necessary follow-up actions got stuck in the absence of an actor who is able and willing to take the lead in the mobilization of (external) resources. When actors have positive relational experiences and develop a negotiated knowledge base, they are more likely to develop such willingness.

Theoretical and methodological reflections and discussions are the subject of Chapter 8 . First, we reflect on the applicability and use of the Contextual Interaction Theory as conceptual lens. For this research, we elaborated the theory in several ways. We conclude that this policy implementation theory offers a compact framework for the analysis of knowledge transfers. On the basis of this research, we recommend, among others, developing the predictive part of the theory further for multi-actor settings. Next, we reflect on the scope and partiality of the evaluation framework. Since this research draws on realtime cases, the ultimate outcomes of the cases were and are yet unknown. Experiences with the ex-post evaluation of a similar case, however, shows that such an evaluation has another important drawback: after a period of several years it becomes much more difficult to attribute observed changes to the case. Drawing on the experiences of practitioners and other studies, we than discuss the generalizability of the case studies. We conclude that the basic evaluation framework can be applied to projects in other sectors, such as the water services sector, and in other countries as well as to projects that are implemented under other conditions. However, in comparison with the case study results, some factors will be relatively more or less important in other projects. This applies, for example, to projects that are part of a longer term partnership or financially supported by the receiving country. We further expect that the strength of bilateral relations and the relative difference between the countries involved has an influence on the effectiveness of knowledge transfer projects.

The last chapter, Chapter 9, provides answers to our research questions and recommendations for research and practice. Our first sub-question is about what criteria help to determine the effectiveness of knowledge transfer projects and how the cases score on these criteria. This question is answered on the basis of the Chapters 3 and 7. Our second sub-question focuses on the interactive process between various actors and is answered on the basis of the Chapters 4 and 5. Our third sub-question concerns the influence of 
contextual factors and the generalizability of the case study results. This question is answered on the basis of the Chapter 2, 6 and 8. Through this research, we learnt that externally supported knowledge transfer projects are less effective than hoped for. In the cases, the transfer of knowledge remained at the level of sharing and acquiring knowledge. Follow-up actions are needed to move towards the application of knowledge. However, follow-up easily gets stuck in the absence of an actor who is able and willing to coordinate or take the lead in developing follow-up actions. We further conclude that an interactive process can change the motivations, cognitions and resources of actors and form a basis for further collaboration, but may also have the opposite effect. At the end of the last chapter, we provide concrete recommendations to research and practice. Additional research, involving more and diverse cases, is needed to confirm the generalizability of our findings and could provide additional insights into the role of contextual factors. Our main recommendation to practitioners is to adopt a longer term perspective on knowledge transfer. Only when projects are seen as building blocks rather than isolated actions, they have the potential to become an important step in achieving desired outcomes. 


\section{Samenvatting (in Dutch)}

Wereldwijd worden landen geconfronteerd met waterproblemen, waaronder een hoog risico op overstromingen. Het overdragen van kennis van het ene naar het andere land kan landen ondersteunen bij het oplossen van deze problemen. Gebruik makend van de ervaringen van door Nederland gefinancierde projecten onderzoekt dit proefschrift de effectiviteit van internationale kennisoverdrachtsprojecten. Het onderzoek baseert zich vooral op casussen waarin kennis van hoogwaterbeheer wordt overgedragen van Nederland naar Roemenië. Beide Europese landen bevinden zich benedenstrooms van een internationaal stroomgebied. Hun bilaterale samenwerking op het gebied van water en milieu gaat terug tot 1995. Sinds die tijd heeft Nederland bijgedragen aan de uitvoering van honderden milieuprojecten in Roemenië. De twee belangrijkste redenen om deze ondersteuning te geven, zowel aan Roemenië als aan andere landen, zijn het leveren van een bijdrage aan het oplossen van waterproblemen en het versterken van de economische positie van de Nederlandse watersector.

In dit onderzoek worden extern ondersteunde kennisoverdrachtsprojecten gezien als interactieve processen door welke actoren uit verschillende landen kennis delen en vergaren met als doel om kennis toe te passen. De centrale onderzoeksvraag luidt: hoe vormen motivaties, cognities, hulpbronnen en interacties van actoren en contextuele factoren het proces en de uitkomsten en beïnvloeden ze de effectiviteit van internationale waterprojecten waarin kennis wordt overgedragen? Om deze vraag te beantwoorden maken we gebruik van de ervaringen van drie, door Nederland gefinancierde hoogwaterprojecten die de afgelopen jaren zijn uitgevoerd in Roemenië. Deze casussen zijn op de voet gevolgd en geanalyseerd met behulp van kwalitatieve onderzoeksmethoden. Als theoretisch uitgangspunt maken we gebruik van de Contextuele Interactie Theorie. Deze theorie beweert dat het verloop en de uitkomsten van kennisoverdrachtsprojecten worden gevormd door de kerneigenschappen dit zijn de motivaties, cognities en hulpbronnen - van de betrokken actoren. Contextuele factoren hebben alleen invloed op een project in de mate waarin ze invloed hebben op deze actoreigenschappen. Deze factoren bevinden zich in drie verschillende lagen: de project specifieke context (zoals geschiedenis en specifieke omstandigheden), de structurele context (ook wel de institutionele of bestuurlijke context) en de brede context (inclusief de politieke, economische, sociaal-culturele, technologische en probleemcontexten). In de 
verschillende casusonderzoeken vullen we deze theorie aan met inzichten vanuit de literatuur over openbaar bestuur (governance), evalueren, overdracht van kennis en beleid en sociaal leren. Het inleidende hoofdstuk van dit proefschrift introduceert de achtergrond en focus, het doel en de vragen, het theoretisch raamwerk, de onderzoeksmethodologie en de opzet van dit proefschrift.

Het centrale onderwerp in hoofdstuk 2 is de structurele context van de casussen. In dit hoofdstuk wordt de Roemeense bestuursstructuur voor hoogwater beoordeeld. Overstromingen komen vrijwel jaarlijks voor en vormen het belangrijkste natuurlijke risico in dit land. Ze veroorzaken grote economische schade en treffen veel mensen. Voor onze beoordeling van de bestuursstructuur baseren we ons op een bestaand bestuursmodel. Dit model wordt verder ontwikkeld met inzichten van de Europese richtlijn voor hoogwater. Ten eerste beschrijven we de bestuursstructuur aan de hand van vijf dimensies: (1) niveaus en schalen, (2) actoren en netwerken, (3) probleemperspectieven en doelambities, (4) strategieën en instrumenten, (5) verantwoordelijkheden en hulpbronnen. Vervolgens beoordelen we de mate waarin deze structuur de implementatie van beleid ondersteunt. Hiervoor maken we gebruik van een tweetal criteria: volledigheid (i.e., in hoeverre worden alle gebruiksfuncties en gebruikers gereguleerd) en coherentie (i.e., in hoeverre zijn de verschillende aspecten met elkaar verbonden). De beoordeling laat zien dat er de afgelopen jaren nieuwe strategieën voor hoogwaterbeheer zijn ontwikkeld in reactie op een toename van het risico op overstromingen en internationale beleidsontwikkelingen. Deze strategieën erkennen dat er meer aspecten een rol zijn gaan spelen in hoogwaterbeheer. Echter, de daadwerkelijke uitvoering van deze 'goede praktijken' blijft uit. Participatieve arrangementen functioneren vaak niet goed, waterbeheerders hebben onvoldoende hulpbronnen, zoals informatie en geld tot hun beschikking en geven nog steeds vaak de voorkeur aan technische verdedigingsmaatregelen boven meer veerkrachtige maatregelen. Met het integreren van meer aspecten in hoogwaterbeheer is de noodzaak voor coherent bestuur eveneens toegenomen. Verschillende maatregelen zijn geïmplementeerd om het aantal interacties tussen verschillende actoren aan te moedigen en te ondersteunen. In de praktijk zoeken actoren echter nauwelijks naar synergie en integratie. Dus, meer inspanningen zijn nodig om zowel de volledigheid als de coherentie van hoogwaterbeheer te doen toenemen, in beleid, maar vooral ook in de praktijk.

Hoofdstuk 3 presenteert een raamwerk voor het evalueren van de effectiviteit van beleidsoverdrachtsprojecten. Het raamwerk wordt toegepast op het project 'Ruimte voor de Rivier in de Kattenbocht, Roemenië'. In dit raamwerk wordt effectiviteit gedefinieerd als de mate waarin een project bijdraagt aan het bereiken van de beoogde of gewenste doelen. Door Nederland gefinancierde projecten zijn effectief als ze helpen om water gerelateerde problemen in het ontvangende land op te lossen en vervolgprojecten genereren. Deze finale uitkomsten zijn vaak nog onzichtbaar aan het einde van een project, maar kunnen voorspeld worden op basis van het proces en de onmiddellijke uitkomsten. Het is waarschijnlijker dat 
een project effectief zal zijn als gebruikers (i.e., actoren met een beslissend aandeel in de uitvoering van het project of vervolgacties) zich verbinden aan het proces. Verbondenheid van gebruikers kan worden gemeten aan de hand van zes procescriteria: betrokkenheid van belanghebbenden, institutionele inbedding, integratie van contextspecifieke kennis, onderling begrip in communicatie, proactieve diffusiestrategie en adaptief management. Hiernaast gebruiken we vier onmiddellijke uitkomstencriteria om te beoordelen in hoeverre actoren een basis voor vervolgsamenwerking hebben gelegd. Deze criteria betreffen de ontwikkeling van een gezamenlijk, motiverend doel, een overeengekomen en valide kennisbasis, het mobiliseren van hulpbronnen en positieve ervaringen in de relationele sfeer (als basis voor vertrouwen). De casus betreft een interactief planproces waarin lokale en regionale belanghebbenden actief zijn betrokken. Als gevolg van dit proces hebben deze belanghebbenden een overeengekomen kennisbasis ontwikkeld over oplossingsrichtingen. Ook zijn ze gemotiveerd geraakt om deze oplossingen verder uit te werken. Echter, deze motivatie en cognitie wordt niet gedeeld door actoren met besluitvormingsmacht, omdat zij niet betrokken waren bij het project. Daarom zijn, bij een gebrek aan hulpbronnen, de gewenste vervolgacties blijven steken. Een verklaring voor deze uitkomsten ligt in de slechte institutionele inbedding van het project en het gebrek aan een proactieve diffusiestrategie en adaptief management. Gegeven deze onmiddellijke uitkomsten is het onwaarschijnlijk dat het project de gewenste uitkomsten zal hebben.

Hoofdstuk 4 geeft een analyse van de rol van actoren, hun kennis en hun interacties in een internationaal kennisoverdrachtsproject. Gebruik makend van de literatuur over kennismanagement en de overdracht van technologie en kennis, onderzoeken we het project 'Test implementatie van FLIWAS in Banat regio, Roemenië'. FLIWAS is een afkorting van een online hoogwater informatie- en waarschuwingssysteem dat hoogwaterbeheerders helpt bij het verzamelen, structureren en presenteren van relevante informatie. De casus laat zien dat actoren met verschillende achtergronden en kennis betrokken zijn bij kennisoverdrachtsprojecten. Vanwege hun verschillende professionele, organisatorische en sociaal-culturele achtergronden hebben deze actoren soms moeite om elkaar te begrijpen, ook al spreken ze dezelfde taal. Om ook de 'stilzwijgende' aspecten van kennis, welke moeilijk in woorden en nummers zijn uit te drukken, te communiceren zijn vaak relatief directere en intensievere communicatiemiddelen en omgevingen nodig om de verschillen tussen actoren te overbruggen, ook al is dit soms onvoldoende. In de casus hebben onder andere actieve samenwerking in teams en een interactieve werkgroep, waarin men kon reflecteren op acties, bijgedragen aan het overdragen van kennis. De casus laat verder zien dat in projecten vaak veel verschillende actoren met verschillende inhoudelijke kennisniveaus betrokken zijn. Wat bijdraagt aan de overdracht van kennis is betrokkenheid van actoren met contextspecifieke kennis van processen en netwerken, evenals actoren die goed zijn in het ontwikkelen en onderhouden van relaties. Het betrekken van actoren met 'interactionele' kennis (i.e., een voldoende hoog kennisniveau om als vertaler van kennis te 
kunnen fungeren) van de contexten van beide landen werkt bevorderend. Ondanks de betrokkenheid van actoren met verschillende capaciteiten was de casus slechts ten dele succesvol. Actoren zijn bereid geraakt om vervolgacties te initiëren, maar hebben niet de intentie om de resultaten van dit testproject te gaan gebruiken.

Hoofdstuk 5 onderzoekt wat de aard en de effecten van leren zijn in internationale kennisoverdrachtsprojecten. We maken gebruik van inzichten uit de literatuur over sociaal leren - i.e., leren dat plaats vindt door interacties met anderen - om te reflecteren op het project 'Integraal waterbeheer in het Tecucel stroomgebied'. De casus laat zien dat interacties bijdragen aan relationele en inhoudelijke leerprocessen. Leren verandert de individuele eigenschappen (i.e., de motivaties, cognities en hulpbronnen) van betrokken actoren. Hiernaast draagt leren bij aan de ontwikkeling van collectieve uitkomsten (deze komen overeen met de onmiddellijke uitkomsten die zijn geïntroduceerd in Hoofdstuk 3), welke een basis kunnen vormen voor een verdere samenwerking. In de casus hebben zowel Nederlandse als Roemeense actoren geleerd in de relationele en inhoudelijke sfeer. Echter, vooral het leren van Nederlandse experts was niet constructief. Dit betekent dat ze minder gemotiveerd zijn geworden om de samenwerking met hun lokale partners te continueren. Lokale Roemeense actoren wilden de samenwerking wel voortzetten. Echter, dit zal waarschijnlijk niet gebeuren aangezien ze niet in staat zijn om de financiële middelen hiervoor te mobiliseren. Een belangrijke uitkomst van het project is dat, op basis van de interacties in de marge van het project, twee Nederlandse actoren besloten hebben een partnerovereenkomst te sluiten met een regionale Roemeense actor. De casus laat zien dat een enkel internationaal samenwerkingsproject meerdere, heel diverse processen van sociaal leren kan bevatten. Of leren ook de basis vormt voor een verdere samenwerking hangt niet alleen af van hoeveel actoren leren, maar vooral van wie, wat leert.

Gebruik makend van de ervaringen van alle drie de casussen onderzoeken we in Hoofdstuk 6 in hoeverre contextuele factoren de actoreigenschappen en dus de effectiviteit van kennisoverdrachtsprojecten beïnvloeden. Na de algemene context van de casussen te hebben ingeleid, laat het hoofdstuk zien hoe de eigenschappen van actoren veranderen ten gevolge van de interactieve processen. Vervolgens reflecteren we op twee mechanismen waardoor contextuele factoren extern ondersteunde kennisoverdrachtsprojecten beïnvloeden. Allereerst laten we zien dat in zulke projecten actoren met verschillende contextuele achtergronden, en dus verschillende motivaties, cognities en hulpbronnen, betrokken zijn. Deze contextuele verschillen bemoeilijken de overdacht van kennis en zijn tevens een aanleiding, en dus een bron van motivatie, voor het overdragen van kennis. De casussen laten zien dat vooral verschillende cognities en hulpbronnen de overdracht van kennis serieus kunnen belemmeren. Ten tweede reflecteren we op de moeilijkheid om kennisoverdrachtsprojecten in te bedden in de context van het ontvangende land. De casussen bevestigen dat het adequaat inbedden van een project een uitdaging is, aangezien een enkel project weinig invloed heeft op de context. Tegelijkertijd is de context verre van 
stabiel en heeft zij de neiging om te veranderen als gevolg van externe ontwikkelingen. We concluderen dat de effectiviteit van kennisoverdrachtsprojecten vooral afhankelijk is van de motivaties en de verbondenheid van machtige actoren aan het proces.

Hoofdstuk 7 vergelijkt de effectiviteit van de drie casussen. Hierbij wordt gebruik gemaakt van het evaluatieraamwerk dat in hoofdstuk 3 is gepresenteerd. Na uitleg te hebben gegeven van de belangrijkste overeenkomsten en verschillen tussen de casussen, reflecteren we op hoe de casussen scoren op de verschillende evaluatiecriteria. De casussen scoren verschillend op de criteria voor het proces en de onmiddellijke uitkomsten. Geen van de projecten scoort hoog op de criteria voor de finale uitkomsten. Vervolgacties zijn nodig om de geadresseerde problemen op te lossen, maar zijn niet gepland in één van de casussen. Slechts één van de casussen leidt waarschijnlijk tot vervolgprojecten die in potentie iets opleveren voor de Nederlandse watersector. We introduceren een ratioschaal om te begrijpen hoe de criteria voor het proces en de onmiddellijke uitkomsten correleren met de finale uitkomsten. De bestudeerde casussen laten vooral een sterke correlatie zien van het proces en de onmiddellijke uitkomsten. Het proces laat ook een correlatie zien met de finale uitkomsten, maar deze correlatie is veel zwakker. Deze correlaties zijn een interessant resultaat, aangezien de criteria nooit waren ontworpen om op deze manier te worden getest. Aanvullende kwalitatieve reflecties op de relaties tussen het proces en zijn uitkomsten laten zien dat vooral 'institutionele inbedding' een sterk verklarende factor is. Deze criteria zijn direct gerelateerd aan het volgen van een 'proactieve diffusiestrategie' en de 'integratie van contextspecifieke kennis'. 'Adaptief management' is belangrijk, maar moeilijk te realiseren aangezien de projecten vaak een kleine omvang en een korte duur hebben om ze aan te passen op basis van relationele en inhoudelijke leerprocessen. Verder vonden we dat in een internationale omgeving extra aandacht moet worden gegeven aan de ontwikkeling van een 'onderling begrip in communicatie'. Het 'betrekken van belanghebbenden' was een belangrijk aspect in alle casussen, maar wordt pas echt relevant in de implementatiefase. Met betrekking tot de onmiddellijke uitkomsten concluderen we dat noodzakelijke vervolgacties vaak blijven steken door de afwezigheid van een actor die de leiding kan en wil nemen in het mobiliseren van (externe) hulpbronnen. Als actoren positieve relationele ervaringen hebben gehad en een overeengekomen en valide kennisbasis hebben ontwikkeld, is het waarschijnlijker dat ze een dergelijke bereidheid ontwikkelen.

Theoretische en methodologische reflecties en discussies zijn het onderwerp van Hoofdstuk 8. Allereerst reflecteren we op de toepassing en het gebruik van de Contextuele Interactie Theorie als conceptuele lens. Voor dit onderzoek hebben we deze theorie op verschillende manieren verder uitgewerkt. We concluderen dat deze beleidsimplementatietheorie een compact raamwerk biedt voor het analyseren van kennisoverdrachten. Op basis van dit onderzoek raden we onder meer aan het voorspellende deel van de theorie verder te ontwikkelen voor toepassing op omgevingen met meerdere actoren. Vervolgens reflecteren we op de strekking en inperkingen van het evaluatieraamwerk. Omdat dit onderzoek 
gebaseerd is op casussen die op de voet zijn gevolgd, waren en zijn hun finale uitkomsten onbekend. Ervaringen met de evaluatie van een vergelijkbare casus laten echter zien dat een dergelijke evaluatie een ander belangrijk nadeel heeft: na het verstrijken van een aantal jaren wordt het moeilijker om geobserveerde veranderingen toe te schrijven aan de casus. Voortbouwend op de ervaringen van praktijkmensen en andere onderzoeken reflecteren we hierna op de generaliseerbaarheid van de casussen. We concluderen dat de basis van het evaluatieraamwerk kan worden toegepast op projecten in andere sectoren, zoals de drinkwater- en afvalwatersector, en in andere landen. Hiernaast kan het ook worden toegepast op projecten die worden uitgevoerd op andere condities. Echter, in vergelijking met de resultaten van de bestuurde casussen, zal een aantal factoren relatief meer of minder belangrijk zijn. Dit is bijvoorbeeld van toepassing op projecten die onderdeel uitmaken van een langer durende samenwerking of financieel ondersteund worden door het ontvangende land. We verwachten verder dat de sterkte van bestaande bilaterale relaties en de relatieve omvang van de verschillen tussen de betrokken landen invloed heeft op de effectiviteit van kennisoverdrachtsprojecten.

Het laatste hoofdstuk, Hoofdstuk 9, geeft een antwoord op onze onderzoeksvragen en aanbevelingen voor onderzoek en de praktijk. Onze eerste onderzoeksvraag heeft betrekking op de criteria die de effectiviteit van kennisoverdrachtsprojecten helpen te bepalen en hoe de casussen scoren op deze criteria. Deze vraag wordt beantwoord op basis van de hoofdstukken 3 en 7 . Onze tweede onderzoeksvraag is gericht op het interactieve proces tussen de verschillende actoren en wordt beantwoord in de hoofdstukken 4 en 5 . Onze derde onderzoeksvraag betreft de invloed van contextuele factoren en de generaliseerbaarheid van de resultaten van de bestudeerde casussen. Deze vraag wordt beantwoordt op basis van de hoofdstukken 2, 6 en 8. Door dit onderzoek hebben we geleerd dat extern ondersteunde kennisoverdrachtsprojecten minder effectief zijn dan gehoopt. In de casussen bleef de overdracht van kennis beperkt tot het delen en opdoen van kennis. Vervolgacties zijn nodig om te komen tot de toepassing van kennis. Echter, vervolg blijft vrij eenvoudig steken bij gebrek aan een actor die vervolgacties wil en kan coördineren of hier de leiding in wil en kan nemen. We concluderen verder dat een interactief proces kan leiden tot veranderingen in de motivaties, cognities en hulpbronnen van actoren en een basis kan leggen voor verdere samenwerking, maar ook het tegenovergestelde effect kan hebben. Op het einde van dit laatste hoofdstuk geven we nog een antal concrete aanbevelingen voor onderzoek en de praktijk. Aanvullend onderzoek, waarin een groter aantal en meer diverse casussen worden meegenomen, is nodig om de generaliseerbaarheid van onze bevindingen te bevestigen en kan leiden tot aanvullende inzichten wat betreft de rol van contextuele factoren. Onze belangrijkste aanbeveling aan praktijkmensen is om een langer termijn- perspectief op kennisoverdracht te volgen. Alleen als projecten worden gezien als bouwblokken, en niet als geïsoleerde acties, hebben ze de potentie om een belangrijke stap te worden in het bereiken van de gewenste uitkomsten. 


\section{Contents}

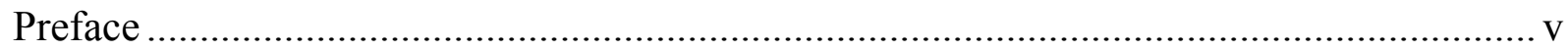

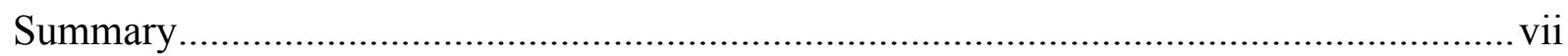

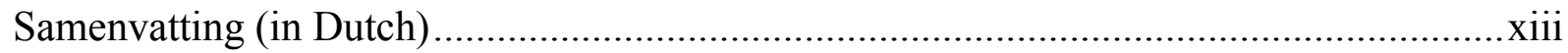

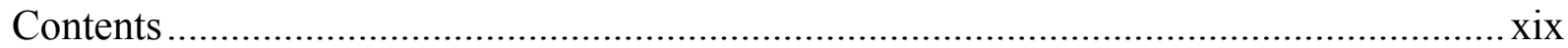

List of tables and figures...........................................................................................

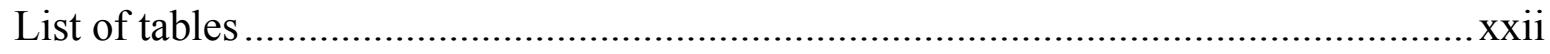

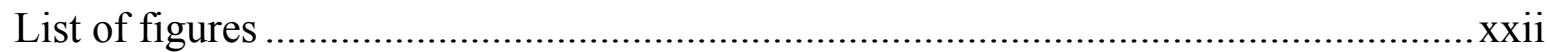

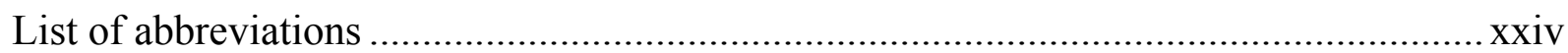

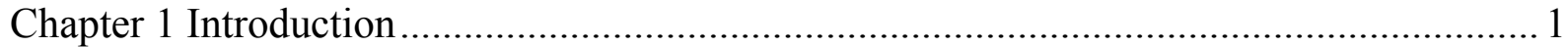

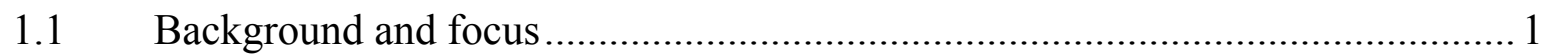

1.2 Dutch-Romanian collaboration on water management ................................. 6

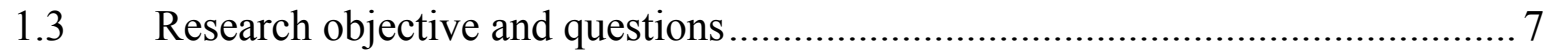

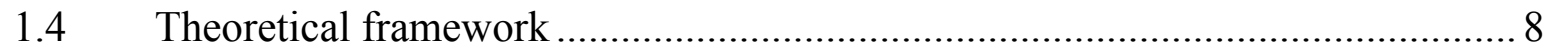

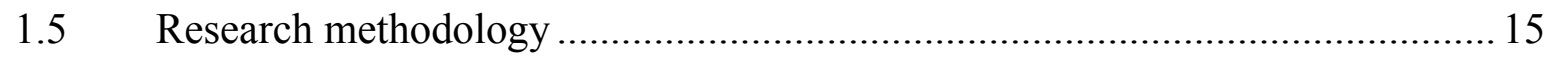

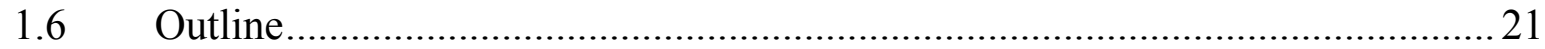

Chapter 2 The Romanian context for flood risk management …................................... 23

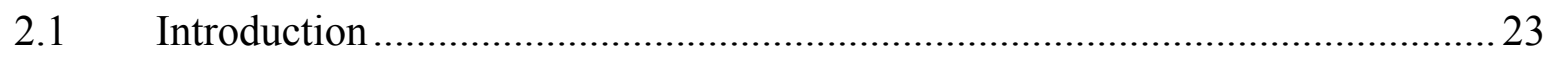

$2.2 \quad$ Assessment framework and methods .......................................................... 25

2.3 Romanian setting for flood risk management................................................. 30

2.4 Governance assessment for Romanian flood risk management ...................... 35

2.5 Extent and coherence as indicators of supportive governance ......................... 42

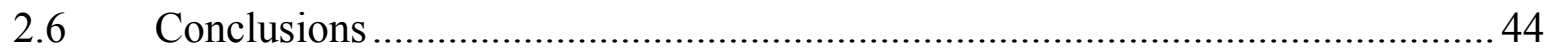

Chapter 3 Case study A: Evaluation of a 'Room for the River' project ............................ 46

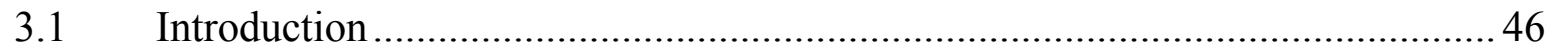


3.2 Evaluation of policy transfer interventions as processes of social interaction ... 48

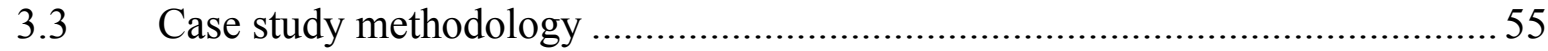

3.4 Case study description: Room for the River in Cat's bend, Romania ................57

3.5 Case study results: application of the evaluation framework ...........................62 62

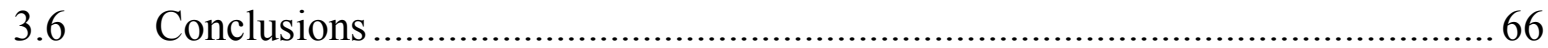

Chapter 4 Case study B: The process of knowledge transfer in a FLIWAS implementation

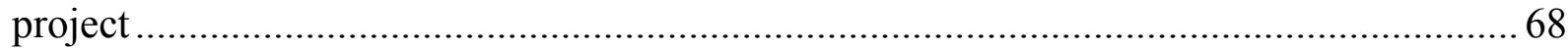

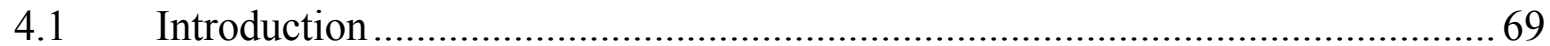

4.2 Knowledge transfer in an international project setting ................................. 70

4.3 Pilot implementation of FLIWAS in Romania................................................ 74

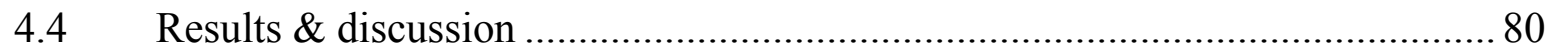

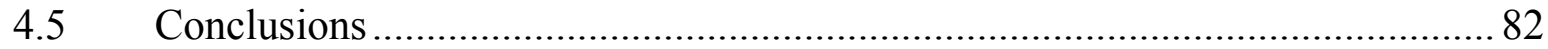

Chapter 5 Case study C: Learning in an Integrated Water Management project................ 84

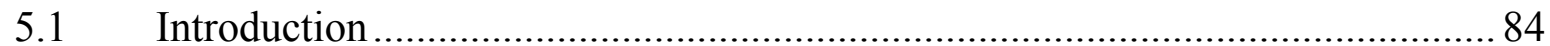

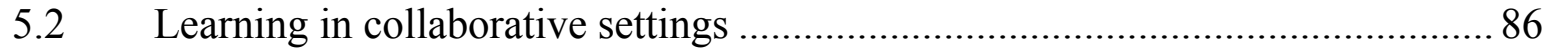

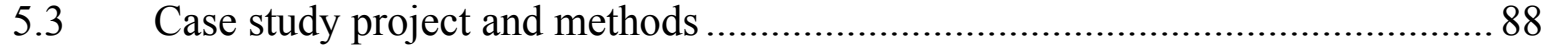

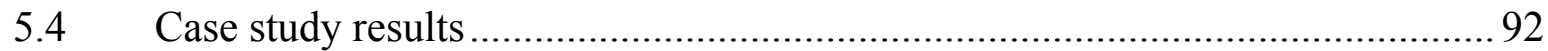

5.5 Discussion: Learning as a basis for further collaboration? ............................. 96

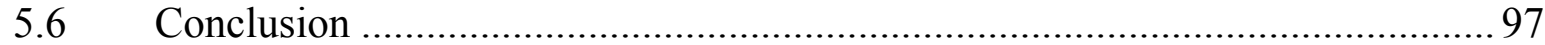

Chapter 6 The influence of contextual factors on the case studies ................................. 99

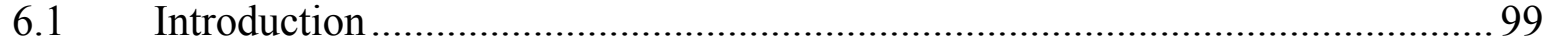

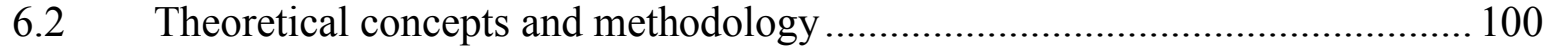

6.3 Dutch-funded flood risk management projects in Romania: context and case studies 103

6.4 Case study results: characteristics of actors involved .................................. 106

6.5 Analysis and discussion: on the role of contextual factors ............................ 110

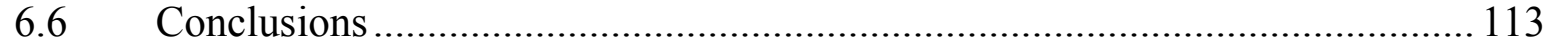

Chapter 7 Comparing the effectiveness of the case studies ......................................... 114

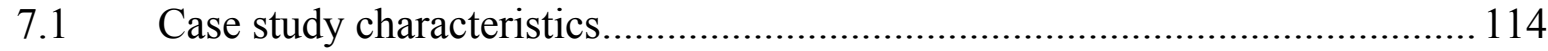

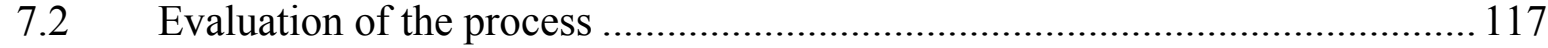

7.3 Evaluation of immediate and ultimate outcomes ........................................ 123 
7.4 Factors that influence the effectiveness of knowledge transfer projects .......... 128

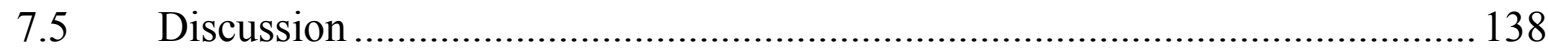

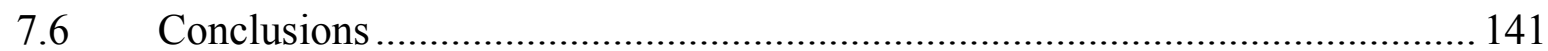

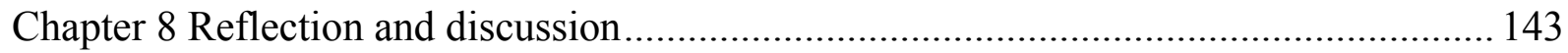

8.1 The Contextual Interaction Theory as conceptual lens.................................. 143

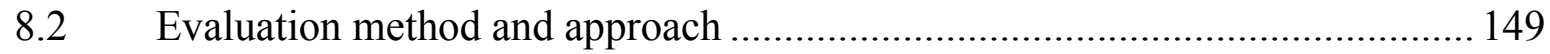

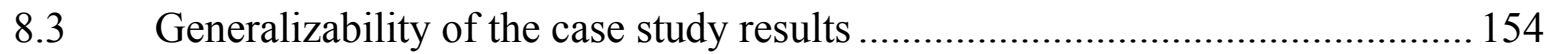

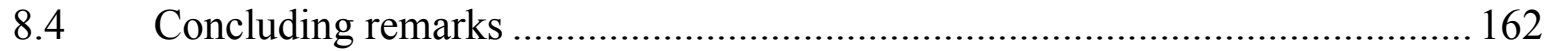

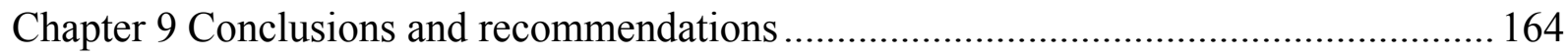

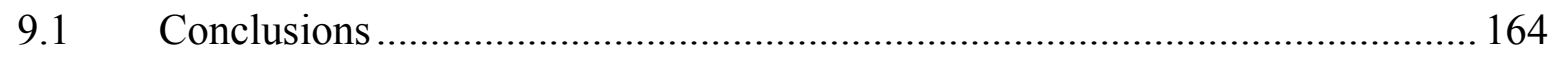

9.2 Recommendations for further research ................................................. 171

9.3 Practical implications and recommendations ........................................... 172

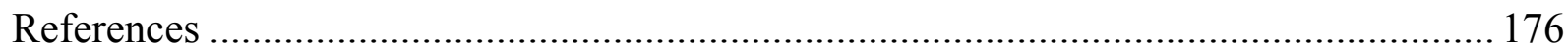

Annex I - List of interviewed and consulted persons................................................... 193

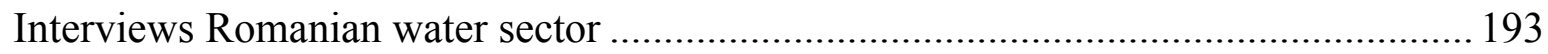

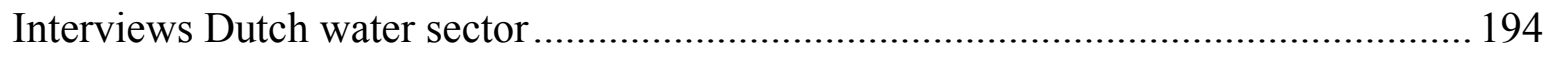

Consultation Dutch water sector (user committee) ................................................. 195

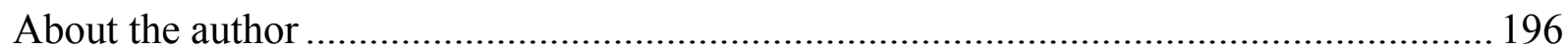

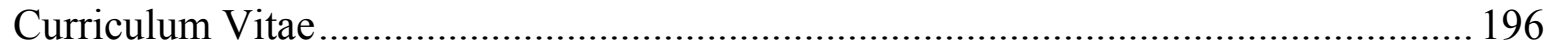

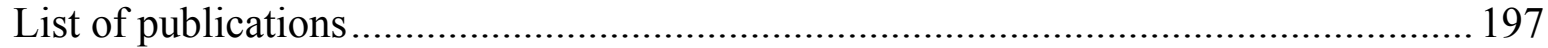




\section{List of tables and figures}

\section{List of tables}

Table 1.1 - Chronological overview of research activities and related results. .18

Table 2.1 - Key questions for the description and assessment of flood risk governance..... 29

Table 2.2 - Overview of actors contributing to flood risk management............................. 34

Table 3.1 - Criteria for the assessment of the process, immediate and ultimate outcomes .. 54

Table 3.2 - Overview of project phases and related activities in case A........................... 60

Table 4.1 - Overview of project activities in case B ....................................................... 75

Table 4.2 - Key organizations, their role and the expertise of experts involved in case B .. 77

Table 5.1 - Overview of missions and (study) visits in case C ....................................... 91

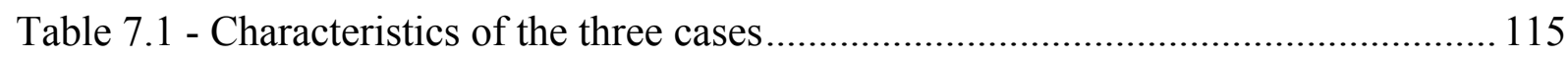

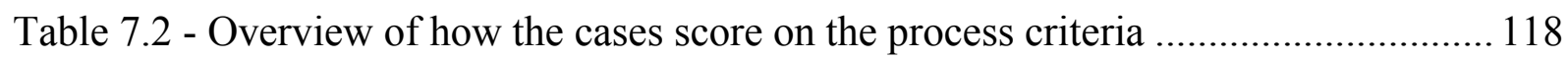

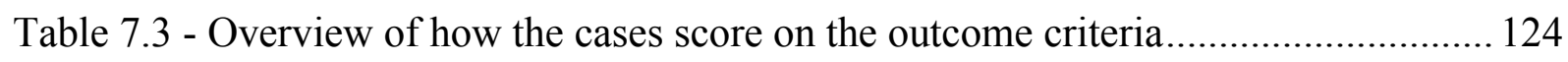

Table 8.1 - Operational definitions of motivations, cognitions and resources................... 146

\section{List of figures}

Figure 1.1 - Conceptual model of projects as processes of social interaction..................... 10

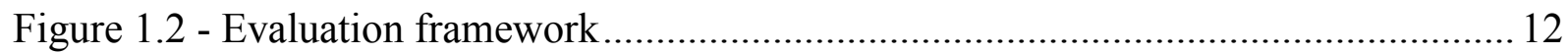

Figure 1.3 - Synthesizing conceptual model of knowledge transfer projects .................... 15

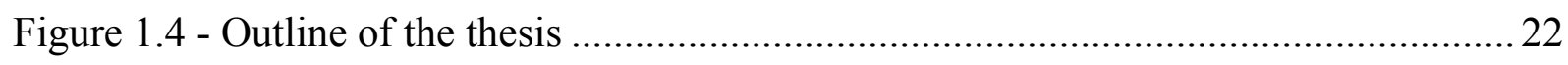

Figure 2.1 - Romania, the Prut River and the Siret River in the Danube River basin......... 32

Figure 3.1 - Policy transfer interventions as social interaction processes ........................ 49

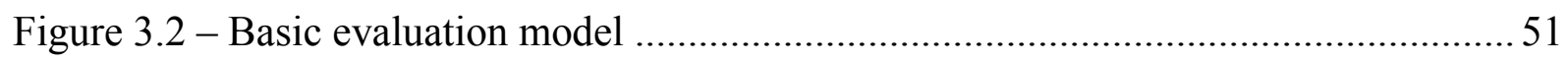

Figure 3.3 - Overview of the project area 'Cat's bend' ...................................................5

Figure 3.4 - Overview of organizations involved in case A .........................................5 59 
Figure 3.5 - The three design concepts that emerged from case A. ................................ 62

Figure 4.1 - Conceptual model for the analysis of knowledge transfer ............................. 73

Figure 5.1 - Conceptual model of the relation between learning and actor characteristics.. 88

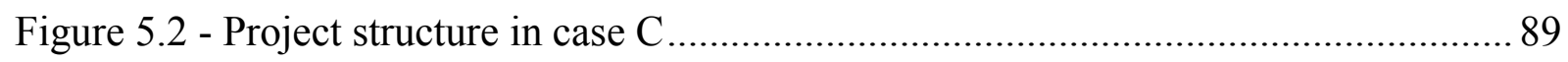

Figure 6.1 - Map of Romania with the location of the three cases ................................. 102

Figure 7.1 - Calculated relation between the process score and the outcome scores......... 129 


\section{List of abbreviations}

DLG (Dutch) Government Service for Land and Water Management

EC European Commission

EEA European Environment Agency

EU European Union

FD Floods Directive

FLIWAS Flood Information and Warning System

GoR Government of Romania

GWP Global Water Partnership

ICPDR International Commission for the Protection of the Danube River

MEF (Romanian) Ministry of Environment and Forests

Min. BuZa (Dutch) Ministry of Foreign Affairs

Min. V\&W (Dutch) Ministry of of Transport, Public Works and Water Management

NARW National Administration Romanian Waters

NIHWM National Institute for Hydrology and Water Management

NWP Netherlands Water Partnership

RWB Regional Water Branch 


\section{Chapter 1}

\section{Introduction}

Water is of vital importance to human life. Social and economic activities and environmental functions all crucially depend on its availability. Water has an impact on all sectors of society and cuts across territorial borders. In our globalized world, water has not only a local, national and transboundary dimension but also a global one. This makes water a complex natural resource to manage. The management of water resources will become even more challenging in the near future. Human pressures on the water system are increasing and climate change is expected to significantly impact our water resources. International collaboration and knowledge transfer may help governments in dealing with these problems and have become a widespread practice in water management. But, are these efforts also effective? To answer this question, we examined three projects in which knowledge about flood risk management was transferred from the Netherlands to Romania. This chapter introduces the contents and structure of this research. The first section provides a general introduction into the background and focus. Section 1.2 presents the research objective and questions. The theoretical concepts that are used in various chapters are introduced in section 1.3. The fourth section describes our methodology, research design and data collection methods. The last section presents an outline of the entire thesis.

\subsection{Background and focus}

\section{Transfer of water management knowledge}

Every year, numerous experts are somehow involved in the transfer of water management knowledge from one country to another. In interaction with other actors, they use knowledge that was developed and applied in one context for solving similar problems in another context. By doing so, actors of different countries can learn from each other and prevent reinventing the wheel. Since many countries face similar water problems, the transfer of knowledge is very relevant. For example, water quality problems are experienced by countries around the world. Floods and droughts already form a major problem in many countries and are only expected to increase as a result of climate change. In addition, some countries already solved certain water problems over the past century. For example, drinking water and sanitation are is a major issue in Africa but no longer in most 
countries in Europe and North America (WWAP, 2012). Therefore, international and supranational organizations and institutions believe that international collaboration can play an important role in solving water problems. In 2009, world leaders agreed at the $5^{\text {th }}$ World Water Forum in Istanbul to "intensify their efforts to reach internationally agreed upon goals such as the Millennium Development Goals" (article 1), "invite international organizations and institutions to support international efforts to enhance the dissemination of experiences and sharing of best practices" (article 17) and "call upon the international community, development partners and private resources of financing to invest resources to complement the efforts made by developing countries and countries with economies in transition, to develop sustainable water resources management" (article 20) (Ministry of Foreign Affairs of Turkey \& World Water Council, 2009). At the European level, international cooperation is strongly promoted in the cohesion policy of the European Commission. Through programmes for cross-border cooperation, transnational cooperation and interregional cooperation it aims to encourage European regions and cities "to work together and learn from each other through joint programmes, projects and networks". Despite the widespread efforts of international and national actors to identify and develop "best practices" and to share and transfer knowledge, the effectiveness of these efforts is questionable (De Boer et al., 2013). International collaboration can accelerate policy development or help solving problems at lower costs but such benefits are often difficult to achieve. Even when countries face similar problems, they often differ in terms of political, institutional, socio-economic or biophysical context. Hence, knowledge developed in one country does not directly fit in another country (Swainson \& de Loe, 2011). Even in a European context, there are huge contextual differences between countries limiting the transferability of knowledge (Stead, 2012). At the same time, developments such as increased access to Internet make the international sharing of knowledge easier than ever (Evans, 2004).

The international transfer of knowledge has been studied in political sciences under the heading of 'policy transfer'. Policy transfer is a generic concept that refers to the process by which policy-relevant knowledge that was developed in one setting is used in another setting (Dolowitz \& Marsh, 2000). It includes related processes such as 'lesson-drawing' (Rose, 1993) and 'institutional transplantation' (De Jong et al., 2002a) as well as processes associated with the diffusion or convergence of public policies (Apostol, 2009). Central in this thesis is the transfer of concrete knowledge in the form of methods, techniques or know-how. This type of knowledge is relatively easy to transfer. Concrete knowledge is easier to understand and specify than policy ideas, principles or philosophies. At the same time, methods or techniques are less specific than programmes, institutes or organization modes (Stead, 2012). The transfer of knowledge is studied in organization sciences under the heading of 'knowledge transfer' or 'technology transfer'. The concepts are used, among others, in studies focusing on the transfer of knowledge from developed countries to 
developing or transition countries (De Boer, et al., 2013; Siggel, 1986; Svensson, 2007; Tihanyi \& Roath, 2002), the transfer of knowledge across companies or branches (of a multinational company) located in different countries (Bresman et al., 1999; Lin \& Berg, 2001; Reddy \& Zhao, 1990) or the acquisition of external knowledge for innovation purposes (Seaton \& Cordey-Hayes, 1993; Trott et al., 1995). The term 'knowledge transfer' is also commonly used to describe the transfer of knowledge across employees in knowledge management studies (Levin \& Cross, 2004).

While the terms 'knowledge transfer', 'policy transfer' and 'technology transfer' do not have the same meaning, they are all relevant when studying transfers in the public domain of water management. In this thesis, we generally use the term 'knowledge transfer', which we define as the interactive process by which actors of different countries share and acquire knowledge about water management for the purpose of applying that knowledge. This definition includes the transfer of policies and technologies. The terms policy transfer and technology transfer are more specific and only used when appropriate.

\section{International water management from a Dutch perspective}

The Netherlands is located in the deltas of three major European rivers: the Rhine, the Meuse and the Scheldt. This position made the country an attractive region for international trade. It is therefore not surprising that the Netherlands has long been a sea-faring nation with an international outlook (Hameeteman et al., 2008). Due to its low-lying position, the country has a long history in water management. As early as the $11^{\text {th }}$ and $12^{\text {th }}$ century, inhabitants started to organize themselves to manage waters and to systemically drain wet areas and to build dykes. In the $13^{\text {th }}$ century, the first democratic district water boards were established (Kuks, 2004). Thus, both technical and institutional developments contributed to the success of the Dutch in mastering their environment. This does not mean that the country's history reads like a heroic epos. Many of the water management efforts were a response to disastrous floods (Reuss, 2002).

Dutchmen are long known for being skilled water managers. Over the past centuries, Dutch water management experts have had a considerable influence on water management in other countries, such as Japan. At the end of the nineteenth century, Dutch engineers were invited by this country to contribute to the development of plans for river improvement, harbours, irrigation systems and flood control. They introduced methods that are still used, such as a unified geodetic system and a project approach based on systemic research and measurements. However, not all projects of the Dutch in Japan were successful. Some projects failed due to miscommunication or a lack of finances or administrative support. Sometimes, the Dutch approach was also not sufficiently adjusted to specific geographic and climatic conditions (Toussaint, 2009).

In recent years, the export of water management knowledge has become an increasingly important theme in Dutch policy. One of the drivers behind this development is a shift in 
foreign policy in 1995. The government stated that while human rights and development assistance continued to be important, foreign policy should focus more on national economic interests (Min. BuZa, 1995). Inspired by this strategy, the subsequent national water policy explicitly mentioned the export of Dutch water management. The policy reads that Dutch water management experts are often invited by other countries to share their knowledge, which creates opportunities for strategic alliances. The policy further signals that fragmentation has a negative impact on the effectiveness and benefits of international projects (Min. V\&W, 1998). In response to this, an interdepartmental steering group was asked to develop an action programme for international water management. The resulting programme focuses on strengthening the economic position of the Dutch water sector, promotion of water-related sustainable development in developing countries and reflection on international water policies. The programme also stipulates geographic and thematic priorities and actions that aim for improved coherence and collaboration (Min. V\&W, 1999).

Recent policies on international collaboration continue along the policy direction that was initiated in the nineties. One of the last governments puts even more emphasis on making investments - instead of providing assistance - in fewer sectors and enlarging the role of the private sector. The government basically wants the Netherlands to engage in less bilateral relations and to focus on themes the country is good at, such as water management (Coalition Agreement, 2010). This vision is elaborated in three different programmes: (1) Global Water (Water Mondiaal); (2) Water for Development (Water OS); and (3) Top Sector Water. The basis for the inter-ministerial programme 'Global Water' is the international chapter of the Dutch National Water Plan for 2009-2015. The programme especially aims to develop intense and long-term partnerships with countries that are located in river deltas and face similar problems (Min V\&W, 2009). The programme 'Water for Development' concentrates on the development of bilateral relations with six developing countries. It is a programme of the Ministry of External Affairs and the Dutch embassies of these countries. Central themes of the programme are efficient water use, the improved management of river basins and deltas, and access to safe drinking water and sanitation. The programme also supports some of the 'Global Water' countries in the development of integrated plans for delta areas (Knapen, 2012). The programme 'Top Sector Water' primarily promotes collaboration between the private sector, knowledge institutes and the government for the development of international business opportunities. Its 'export and promotion team' recently developed an international strategy in which it specifies which countries offer most business opportunities and how the government can help them using these opportunities (Topteam Water, 2011).

International water management also has the attention of water companies and regional water boards. In 2007, the Dutch water sector (including the water boards and water companies) committed themselves to the realization of the Millennium Development Goal 
on access to safe drinking water and sanitation (Min. BuZa, 2007). This commitment was given for reasons related to corporate social responsibility (to contribute to the solving of water problems) and employability (to train and motivate employees). Since 2008, the water companies are officially allowed to spend up to $1 \%$ of their return on international water projects. They especially engage in Water Operator Partnerships with operators in developing countries (Vewin, 2009). In 2009, the Assembly of the Dutch Water Boards agreed to stimulate the involvement of water boards in international (development) projects. Around the same period, water boards and sewage companies also became officially allowed to employ their knowledge and expertise for water projects in developing countries (Unie van Waterschappen, 2011). In addition, a wide range of other public and private actors (e.g. consultancies, industries, non-governmental or semi-public organizations) are involved in the export of Dutch water management knowledge.

\section{Dutch support for international water projects and activities}

The national government has long been actively supporting the international activities of the Dutch water sector. This support is given directly in the form of project subsidies and indirectly through the organization of networking, marketing and business development activities. In strengthening the international position of the Dutch water sector, the programme 'Partners for Water' plays a key role. In 1999, the national government initiated this programme for the purpose of improving collaboration and cooperation. The programme supports a wide range of international activities of the Dutch water sector and financially supports international water projects. Currently, the programme also contributes to the implementation of 'Global Water' and 'Water for Development' policies, for example, through the establishment of country platforms and coordination and marketing activities. 'Partners for Water' continues to support innovative projects of the Dutch water sector in 26 countries, on the condition that these projects are likely to result in follow-up activities (Min. V\&W, 1999; Partners voor Water, 2012b). A wide variety of additional programmes is available for supporting projects. For example, the Facility for Infrastructure Development (ORIO) supports the development of public infrastructure and the newly established Sustainable Water Fund (a Public Private Partnership) supports projects in the area of water safety and water security. Both programmes of the Ministry of Foreign Affairs support projects in a wide variety of developing or emerging countries in Africa, Asia and the Middle East, Eastern Europe and Latin America. In addition, there are facilities that aim at specific countries or specific actors (NL Agency, 2012).

Actors who play an important role in promoting the export of Dutch water management include NL Agency (an agency of the Ministry of Economic Affairs, Agriculture and Innovation) and the Netherlands Water Partnership (NWP), who jointly implement, since 2005, 'Partners for Water'. NWP is a public-private network organization that was established in 1999. The network stimulates collaboration and cooperation between various 
actors with a role in water management, such as ministries, knowledge institutes, water boards, water companies, NGOs, industry and consultants. Among its main activities are the publication of promotion material, the coordination of Dutch involvement in conferences and exhibitions and the organization of business development trips, workshops and other networking activities (NWP, 2012). In developing countries, the DirectorateGeneral for International Cooperation (of the Ministry of Foreign Affairs) and the Dutch embassies often play a key role in the coordination and support of international water projects.

\subsection{Dutch-Romanian collaboration on water management}

This research focuses on water projects that involve the transfer of knowledge from the Netherlands to Romania. Like the Netherlands, Romania is a European country and home to the delta of an international river basin. The collaboration between both countries dates back to 1995 when their Environmental Ministries signed a Memorandum of Understanding in the domains of water and environment. Within the context of this Memorandum, the Dutch government directly funded several projects. In 1998, both countries signed another bilateral agreement, which led to a gradual increase of Dutch-funded projects. At that time, financial support was especially given through programmes like Matra (Social Transformation Programme for Central and Eastern Europe) and PSO/PSOM (an Emerging Markets Cooperation Programme, replaced by the Private Sector Investment programme). Between 1995 and 2007, about 140 projects in the field of environment and water (costing over 20 million euro) were implemented with the support of these and other financing instruments. After 2007, when Romania became a member state of the European Union (EU), the Netherlands started to phase out its bilateral assistance. Nevertheless, Dutch public and private organizations still implement projects in Romania. Also, bilateral contacts between both countries continue to exist (RNE \& EVD, 2009). Between 2005 and 2010, 'Partners for Water' supported about 60 projects of which 10 were implemented in Romania (Partners voor Water, 2012a). For the period until 2015, the programme carries on with providing support for innovative water projects in Romania.

For the private sector, Romania is an attractive market. At the moment, huge investments are needed to bring Romania's environmental infrastructure in line with EU standards. For this, Romania highly depends on foreign suppliers and expertise as it lacks domestic capacity and expertise. To strengthen the position of the Dutch water sector in Romania, a Romania platform was established by the NWP in 2008 (Van Peppen, 2008). Furthermore, governmental organizations of both countries engaged in new collaborations. In 2008, the Union of Dutch Water Boards and the National Administration for Romanian Waters signed a Memorandum of Understanding. Together with the Romania platform of NWP, the Union also established a Dutch-Romanian panel consisting of high executives and civil servants of both countries. Within this context, regular meetings are organized in which the 
challenges of living in a delta area are discussed. In addition, several individual water boards are or were involved in Dutch-Romanian projects. In recent years, the bank of the Dutch water boards financed projects of two water boards in Romania. Furthermore, various projects were implemented as part of the collaboration between the Dutch Province of Overijssel (including six water boards) and the Romanian County of Teleorman (Unie van Waterschappen, 2011, 2012; Vinke-de Kruijf, 2009b). In addition, Dutch organizations organized various activities to promote Dutch-Romanian collaboration over the past few years, such as Dutch-Romanian delta dialogues and exchanges focusing on water technology.

\subsection{Research objective and questions}

The subject of this research is externally supported projects that involve the transfer of knowledge about water management from one country to another. They are 'externally supported' in the sense that most funds (alongside expertise) are contributed by the transferring country. In other words, they involve exporting actors who are proactive in spreading their knowledge as well as importing actors who are interested in drawing lessons (Stone, 1999). We use qualitative case study research as main research strategy and examine three projects that involve the transfer of knowledge about flood risk management from the Netherlands to Romania. We focus on floods that are caused by rivers going beyond their normal confines (i.e. causing inundations) and have negative consequences for society. In this thesis, flood risk management refers to all decisions and actions that are undertaken to assess, analyse and reduce flood risks. This includes all actions that are meant to maintain or increase the ability of an area to cope with peak discharges (De Bruijn et al., 2007; Samuels et al., 2006; Schanze, 2006).

An important objective of this research is to provide new insights in the factors that influence the effectiveness of externally supported knowledge transfer projects. We aim at achieving this objective by describing, evaluating and explaining the process and outcomes of such projects. Within this context, we see projects as interventions, i.e. actions that are taken "for the purpose of producing some intended result" (Babbie, 1992, p. 347). We define the effectiveness of a project as the degree to which it contributes to the achievement of the intended or desired outcomes. In the cases, we evaluate the intended or desired outcomes in terms of the two overarching objectives of Dutch policies on international water management. These objectives are to contribute to the solving of water-related problems in the benefiting country and to generate follow-up projects for the Dutch water sector. In examining the process and outcomes of these projects, we assert that knowledge transfer projects are processes of social interaction that are shaped by the characteristics i.e. the motivations, cognitions and resources - of actors involved. Contextual factors influence these processes via the dynamic interaction between the characteristics of actors involved (Bressers, 2004, 2009). 
The central question of this thesis is: How do actors' motivations, cognitions and resources, their interactions and contextual factors shape the process and outcomes, and influence the effectiveness, of international water projects that involve the transfer of knowledge? This question is divided into three sub-questions:

1. What process and outcome criteria help to determine the effectiveness of knowledge transfer projects and how do the cases score on these criteria?

2. How do the interactions between actors with diverse motivations, cognitions and resources shape the process and outcomes of knowledge transfer projects in the cases?

3. How do contextual factors shape the process and outcomes of knowledge transfer projects and what does this imply for the generalizability of the case study results?

\subsection{Theoretical framework}

\section{Theoretical perspectives on knowledge transfer in the public domain}

As explained in the first section of this chapter, the transfer of knowledge is studied under the different headings of policy, knowledge and technology transfer. These concepts have different meanings but they all provide relevant insights into the transfer processes under study. They complement each other since the literature on 'policy transfer' draws attention to the public dimension of transfers and the literature on 'knowledge transfer' and 'technology transfer' focuses more on interpersonal and organizational dimensions. Given the public administrative background of this thesis, we could have chosen to take policy transfer literature as starting-point but we decided instead to base our research on policy implementation theory. Before explaining this choice, we first shortly introduce the literature on policy transfer.

Policy transfer studies can be divided broadly in transfer studies and diffusion studies. Both types of studies have another focus and approach. Diffusion studies concentrate on factors that explain the adoption of knowledge and are usually based on large, quantitative studies. Policy transfer studies pay more attention to process questions, such as who, what, why, where and how, and are often based on in-depth case studies (Dolowitz \& Marsh, 1996; Mossberger \& Wolman, 2003). Both studies provide different explanations for knowledge transfer. In diffusion studies, transfers are explained on the basis of the structural similarities and differences between the countries involved. Transfer studies emphasize the actors involved and their ability to adapt knowledge to context-specific factors and needs. One could expect that transfers are easier between countries that are more similar in political, legal and cultural terms. However, comparative research shows that transfers between dissimilar countries are often more successful than transfers between countries that belong to the same 'family of nations'. A probable explanation for this is that although countries seem to be similar, they still face different practical and institutional issues 
implying that national, regional and local factors and needs should be considered and adapted for (De Jong, 2004; De Jong \& Mamadouh, 2002). This implies for transfer studies, that they should - ideally - pay attention to agents (actors), structure (context) and the complex relation between them. 'Agents' refer here to the actors involved in the transfer (and their role and motives) and structure to the international, national and organizational context of a transfer (Evans, 2009b; Evans \& Davies, 1999).

Studies on policy transfer are considerable in number but have important flaws. In particular early studies conceptualize transfers as a process in which nation A adopts an idea from nation B. However, in most cases, reality is much more 'networked', implying that transfers result from the involvement of multiple, mutually dependent actors. Therefore, it may be useful to also build upon insights from public policy, politics and organization studies (De Jong \& Edelenbos, 2007). For example, a recent study shows that policy transfers can be conceptualized fruitfully as communication processes that involve producers, senders and receivers of information and facilitators (De Jong \& Edelenbos, 2007; Wolman \& Page, 2002). Another flaw of transfer studies is that they provide little insights into the effects of such processes and thus also in the factors that explain their success (James \& Lodge, 2003; Marsden \& Stead, 2011). Since there are no reasons to assume that policy transfers are fundamentally different than regular policy processes, researchers preferably focus on other, more developed, literature streams that specifically focus on the topics they are interested in (James \& Lodge, 2003). We follow this reasoning and primarily build upon policy implementation theory to explain policy transfers in a water management context. The theory offers a compact framework for the study of transfer processes by focusing on three key characteristics of actors involved, thereby reducing the number of variables. However, since the theory was not developed for the evaluation of knowledge transfers, we complemented the theory with insights from various literature streams. The next sections explain the theory and the additions that were made for the purpose of this research.

\section{Knowledge transfer projects as processes of social interaction}

The policy implementation theory that is used as starting-point for this research is the 'Contextual Interaction Theory'. This theory is rooted in various studies on policy implementation, instrumentation theory, network analysis and governance that were undertaken at the University of Twente in the past two decades. The theory offers a compact actor-centred framework for explaining policy processes. It sees policy implementation as a multi-actor process that is driven by the interaction between actors involved. Based on this theory, we assume that the course (or process) and outcomes of knowledge transfer projects basically result from the dynamic interaction between the characteristics of actors involved. These characteristics are their motivations (what drives their actions), cognitions (information held to be true) and resources (capacity to act and 
sources of power) (Bressers, 2004; De Boer \& Bressers, 2011). Central questions in the analysis of such interaction process are not only who interacted with whom, how, where and when but also: What are the substantive and procedural reasons (motivations) of actors involved for being involved or for taking certain actions? What are the perceptions (cognitions) of actors involved about the relevance of the project, the adopted approach or method, the urgency, nature and meaning of the problem at stake, potential solutions and achievements? What is the capacity of actors to act (finances, manpower and knowledge) and their power to get things done (institutional resources)? (Bressers \& Kuks, 2004; Owens, 2008; Vinke-de Kruijf, 2011b).

Project objectives are not realized in isolation; projects influence and are influenced by a dynamic project context (Vinke-de Kruijf et al., 2010). Contextual factors influence the course and outcomes of an interactive process only by the degree to which they influence the characteristics of actors involved. Firstly, actor characteristics are affected by a projectspecific context, which includes the history of a case (e.g. previous decisions and choices) and specific circumstances (e.g. geographic setting). Secondly, actor characteristics are influenced by a more encompassing structural or institutional context. Projects in the public domain, especially water projects, are often embedded in a complex multi-actor setting. While public authorities play a key role in such projects, they cannot implement flood risk management policies on their own. Due to the fragmentation of resources, they usually need to collaborate with a wide range of actors, both public and private, at different levels of society. Thirdly, the interactive process may be influenced by the wider political, economic, socio-cultural, technological and problem contexts (Bressers, 2009). The conceptual model that forms the starting-point for our understanding of knowledge transfer projects is schematized in Figure 1.1. The figure includes two actors, which are meant to represent multiple actors. The arrow from process to context is dotted since the process' influence on its context is beyond the scope of this thesis.

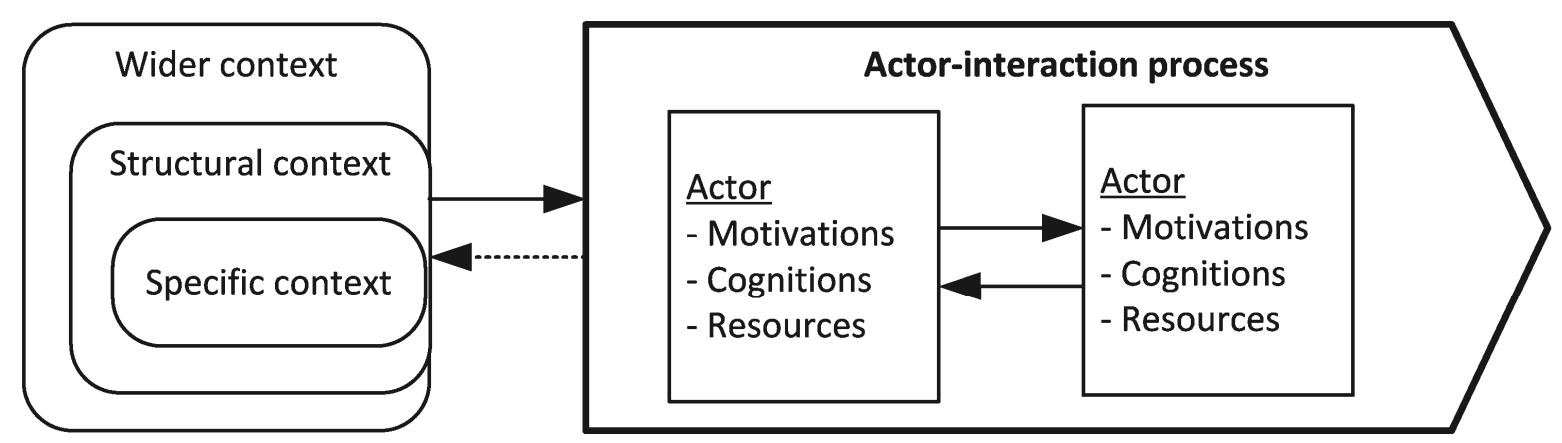

Figure 1.1 - Conceptual model of projects as processes of social interaction that are driven by the dynamic interaction between motivations, cognitions and resources of actors involved, which in turn is influenced by a wider, structural and specific context (Bressers, 2009) 


\section{Effectiveness of knowledge transfer projects}

Effectiveness is defined here as the degree to which an intervention - a project in this case - contributes to the achievement of intended or desired outcomes. To understand how actors, interaction and context influence the effectiveness of a knowledge transfer project, we complement the presented theory of policy implementation with insights from literature on evaluation, public policy, knowledge management, policy transfer and social learning. These additions are discussed in more detail in chapter 4, 5, 6 and 7 of this thesis. This subsection provides an overview of theoretical concepts that are introduced in these chapters.

Evaluation literature shows that the effectiveness of an intervention can be assessed by reflecting on its process, immediate outcomes and ultimate outcomes (Rossi et al., 2004; Scriven, 1991). The desired outcomes of knowledge transfer projects depend on their actual purpose and therefore vary from case to case. The purpose of Dutch-funded projects is basically to contribute to the solving of water-related problems in the benefiting country and to generate new projects (spin-off) for the Dutch water sector. These impacts often only become visible on the longer term. In order to predict what ultimate outcomes are reasonable to be expected, we developed an evaluation framework (see Figure 1.2) that connects the process to immediate outcomes that, in turn, are expected to lead to more distal outcomes (Rossi, et al., 2004). The framework is based on the recognition that resources tend to be spread among multiple actors with diverse motivations and cognitions (Bressers, 2004; Koppenjan \& Klijn, 2004). These characteristics change during the course of an interactive process. The likelihood that intended outcomes are realized depends on whether users - i.e. actors with a crucial role in the intervention itself (current critical actors) or in follow-up actions (future critical actors) - are successfully engaged in the process (Faludi \& Altes, 1994; Patton, 1978; Vreugdenhil, 2010; Walter et al., 2007). Successful engagement includes that relevant experts, authorities and other stakeholders understand each other and that their perspectives and knowledge are taken into account. When this is the case, their interactions are more likely to result in a basis for further collaborative actions. Such a basis involves that actors agree upon a motivating goal and the required knowledge base and have access to the necessary resources to complete a desired action (Bressers, 2004; Owens, 2008). We refer to the required knowledge base as 'negotiated knowledge', this is knowledge of which actors agree upon its scientific validity, significance and meaning (Hommes et al., 2009b; Koppenjan \& Klijn, 2004).

Although a joint motivating goal, negotiated knowledge and the mobilization of necessary resources form an important basis for joint action, voluntary collaboration is unlikely to emerge without trust. Trust refers to an actors' willingness to accept vulnerability on the basis of its expectations. Trust is especially relevant when actors face uncertainties and depend on other actors. In relatively new relations, an actors' willingness to trust is not deeply rooted as actors have limited information about each other - even though they can 
have high expectations of one another. When actors interact with each other over a longer period of time, their relational experiences provide them with additional information about each other. Positive relational experiences make actors more willing to trust other actors. Negative experiences have the opposite effect (Rousseau et al., 1998). Trust plays an important role in knowledge transfers. If actors believe that a knowledge producing network is trustworthy, they are more likely to consider produced knowledge to be true (Carolan, 2006). Generally speaking, knowledge exchange fails without trust and a lack of trust is a reason for not using knowledge (Davenport \& Prusak, 1998). Studies on the relation between knowledge transfer and perceived trustworthiness confirm that positive cognitions of another actor's intentions (motivations) and ability (resources) have a positive influence on knowledge transfer (Levin \& Cross, 2004). In this research, we see trust especially as a collective resource, but it can also be seen as a cognition or an attributed resource (Bressers, 2009). Mutual trust can be a strong motivational factor and accelerate collaboration processes (De Boer \& Bressers, 2011).

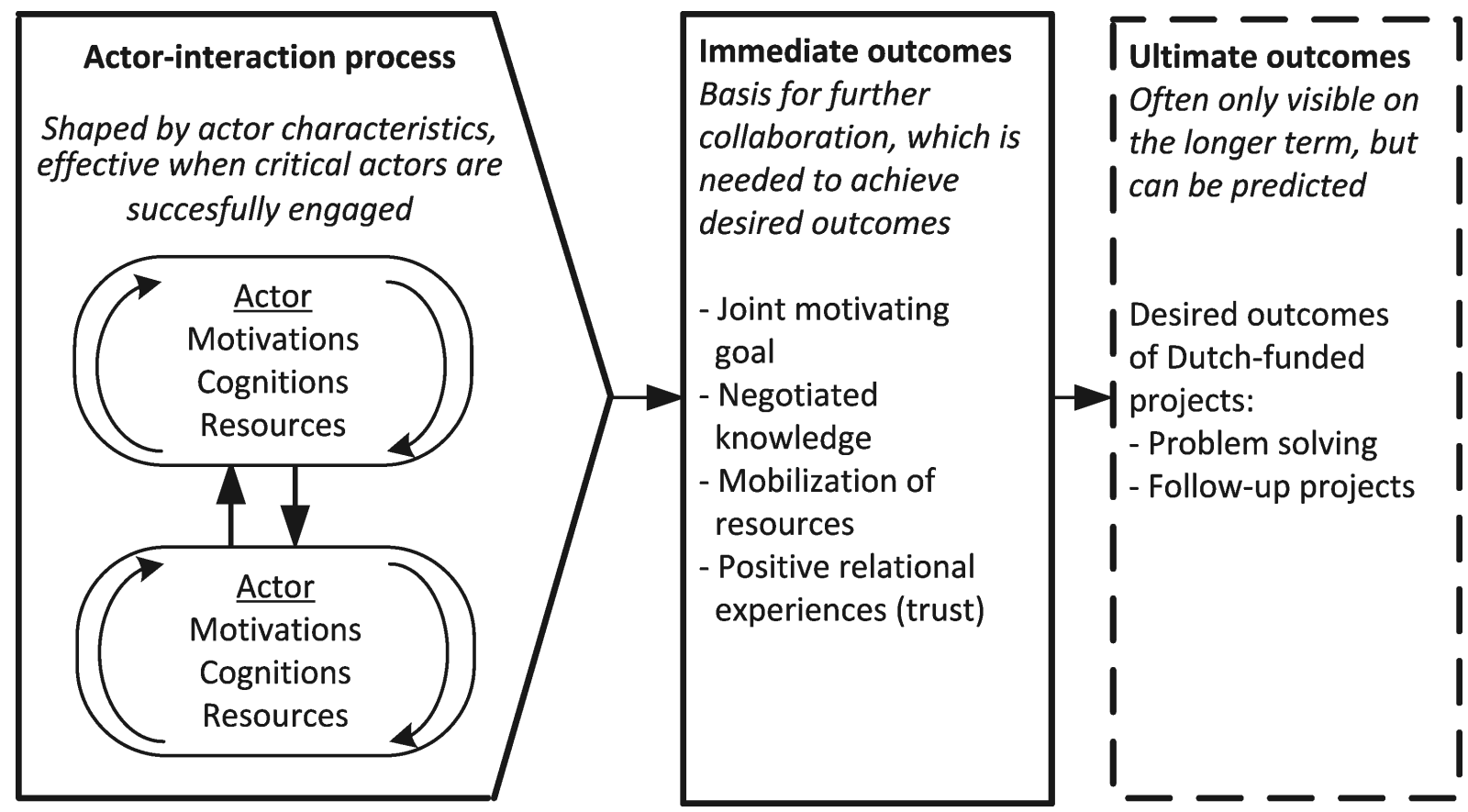

Figure 1.2 - Evaluation framework showing that an interaction process changes actor characteristics and leads to immediate outcomes on the basis of which ultimate outcomes can be predicted

The literature on knowledge management provides additional insights in how actors and their interactions influence the effectiveness of a knowledge transfer process. Knowledge transfers tend to involve a large portion of tacit knowledge or specialized know-how (Lin \& Berg, 2001; Reddy \& Zhao, 1990; Trott, et al., 1995). 'Tacit' means that knowledge is rooted in a background that is hard to formalize or communicate (Polanyi, 1966). Actors with knowledge backgrounds that diverge in socio-cultural, professional and organizational terms tend to have difficulties to understand and accept each other's knowledge (Stenmark, 2002). Knowledge management literature highlights that communication means and interaction mechanisms differ in their capacity to exchange tacit knowledge and to develop 
new knowledge (Boh, 2007; Bresman, et al., 1999; Koskinen et al., 2003; Nonaka, 1994). The diverging backgrounds of actors also imply that they have knowledge that differs in content and orientation (Hommes, et al., 2009b). This means that actors, depending on their type and level of knowledge all have their own capacity to contribute to the knowledge transfer process (Collins \& Evans, 2002; Leeuwis \& Van den Ban, 2004; Wesselink et al., 2009).

Interactive processes may result not only in tangible outcomes, such as a concrete agreement or plan, but also lead to intangible outcomes, such as shared knowledge, relations and trust (Innes \& Booher, 1999). We associate these intangible outcomes with changes in the characteristics of actors involved. The Contextual Interaction Theory acknowledges that actor characteristics change during an interactive process but does not fully elaborate the role of learning in these changes (Owens, 2008). Learning that results from interaction with others is analysed in the literature under the heading of 'social learning' (Maarleveld \& Dabgbégnon, 1999; Muro \& Jeffrey, 2008). Learning includes an increase of knowledge, insights and skills in the area of content (substantive learning) and process (relational learning) (Koppenjan \& Klijn, 2004; Pahl-Wostl et al., 2007a). Social learning can result in the development of qualities that go beyond individual knowledge and skills and therefore increase the capacity of actors to jointly perform a task (Pahl-Wostl, et al., 2007a). In addition, learning can remain at the individual level, leading to an increase of individual knowledge and skills (Gerlak \& Heikkila, 2011). Where social learning is often associated with the development of mutual trust, relations and shared understandings, it may also worsen relations or deepen differences in views (Muro \& Jeffrey, 2008). Thus, interactions may involve constructive learning processes that result in converging ways of thinking and form a pathway for future cooperation as well as unconstructive learning processes that have the opposite effect (Vreugdenhil, 2010). Individual learning becomes visible in positive or negative changes in motivations, cognitions and resources; collective learning in the construction or deconstruction of a joint motivating goal, negotiated knowledge, pooled resources and trust. These immediate outcomes contribute to the solving of water management problems, sometimes directly but usually through further collaboration.

One of the basic assumptions of the Contextual Interaction Theory is that context only shapes the course and outcomes of an interactive process via the characteristics of actors involved. Over the past few years, the relation between context and interaction process was further investigated and elaborated (De Boer, 2012). This research aims to provide additional insights in how contextual factors influence the interaction process by analysing knowledge transfer processes. In such processes, contextual differences between the transferring country and the receiving country imply that: (1) actors tend to have relatively more asymmetric and diverging motivations, cognitions and resources which is likely to complicate their interaction; and (2) contextual characteristics and circumstances of the 
receiving country may form an obstacle towards knowledge application and lead to unexpected changes in cognitions, motivations and resources. Wider and structural contexts are rather stable and unlikely to change as a result of a single project (De Boer \& Bressers, 2011). This does not mean that contexts do not change. External developments, such as changes in the economic situation, the availability of new technologies or the political composition of the government, can provide new opportunities for mutual solutions and cooperation as well as eliminate support, thereby influencing also a process (Koppenjan \& Klijn, 2004). Thus, projects are influenced by their dynamic contexts, which are unlikely to be changed by single projects.

\section{Synthesis}

To understand the interactive process by which actors transfer knowledge in an international setting, we build upon a wide range of literature. Figure 1.3 integrates our main concepts and ideas into one conceptual model of knowledge transfer projects. Central in this figure is the knowledge transfer process in which actors share and acquire knowledge for the purpose of applying this knowledge. To examine the course and outcomes of this process, we distinguish between an interactive process, immediate outcomes and ultimate outcomes. The process is shaped by the motivations, cognitions and resources of interacting actors. The rounded arrows in the actor boxes of the figure indicate the dynamic nature of actor motivations, cognitions and resources. The shaded boxes at the background of the actor boxes indicate that actors tend to have considerable different backgrounds and knowledge. These differences influence their ability to communicate and understand each other. When actors manage to communicate and interact, they are likely to learn from and about each other. These learning processes involve changes in the actor characteristics and may contribute to the development of immediate outcomes on which further actions can be based. We distinguish between four types of immediate outcomes: a joint motivating goal, a negotiated knowledge base, mobilization of resources (if necessary, by pooling them) and positive relational experiences (as a basis for trust). The box with ultimate outcomes draws attention to the overall objectives of Dutch-funded projects, which are to contribute to problem-solving and to generate follow-up projects. The conceptual model further shows that a knowledge transfer process does not occur in isolation but is implemented against the background of the case-specific, structural and wider contexts. They have no direct influence on the process but shape the characteristics of actors involved. 


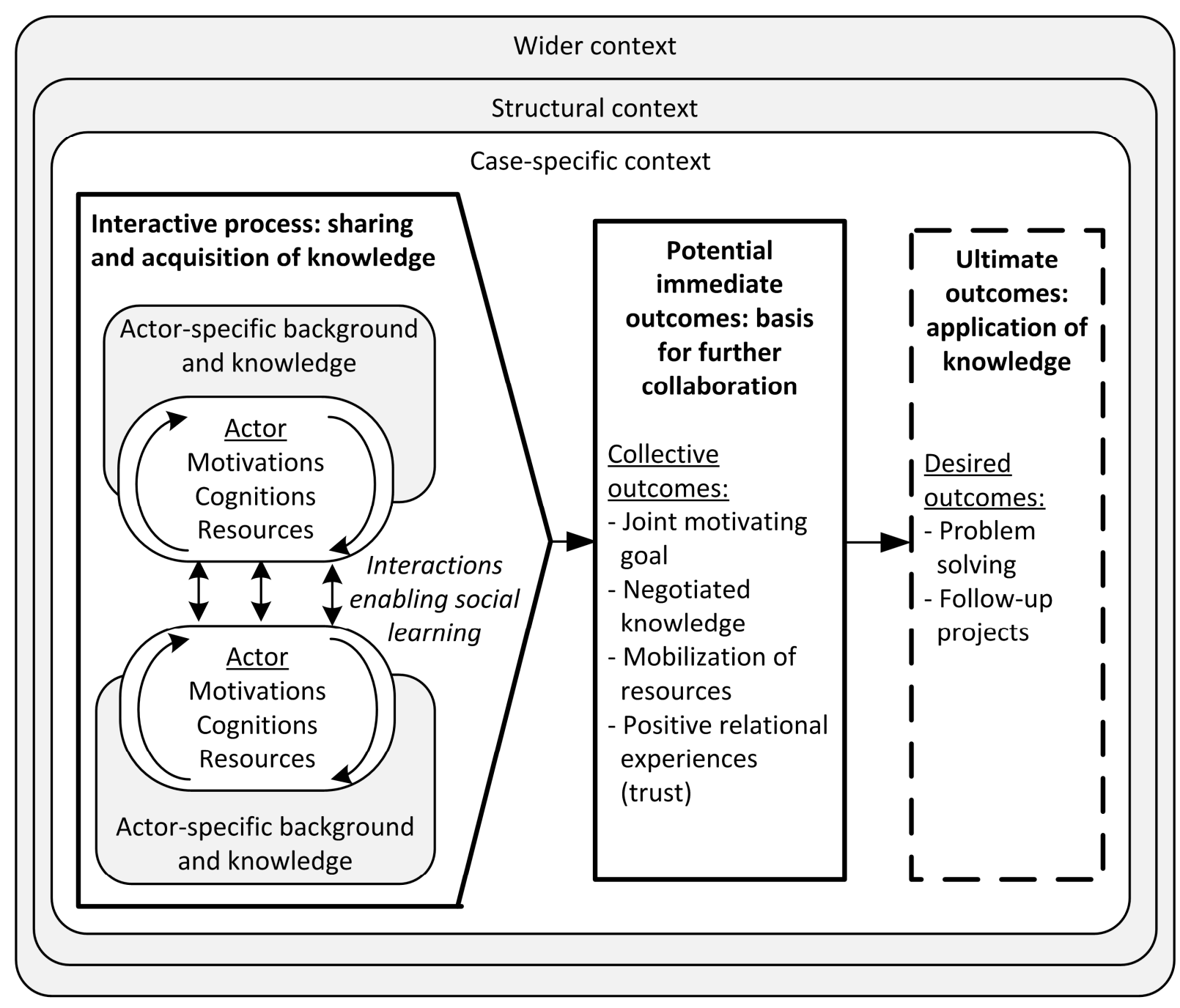

Figure 1.3 - Synthesizing conceptual model of knowledge transfer projects

\subsection{Research methodology}

This research builds upon a wide variety of theoretical insights about water management, policy sciences and related disciplines. Through this research, we aim to develop knowledge that has scientific and practical relevance for the water management sector. This section starts with a short introduction of the kind of knowledge that is central in this research. Next, it explains the research design and the collection and analysis of data.

\section{Knowledge for the water management domain}

For a long time, water was mostly seen as a resource that could be planned and controlled. Water management was largely shaped by technical experts who developed solutions to clearly defined problems. Central in this 'command and control' approach was the disciplinary knowledge of engineers. Although traditional approaches are still firmly entrenched in many water institutions, there has been and is a growing awareness of the need for change. It is widely acknowledged, especially in developed countries, that water 
problems are embedded in a complex natural and social system. Rather than being clearly defined problems, water problems are complex and unstructured. This means that they are characterized by the involvement of multiple actors with diverging interests and perceptions and incomplete knowledge. Such problems require an integrated and participatory approach that pays attention to the human, technological and environmental aspects of a problem (Hommes, 2008; Pahl-Wostl, 2002; Van der Brugge \& Rotmans, 2007; Van der Brugge et al., 2005). This imposes new challenges to knowledge production, since it requires the involvement and integration of various disciplines (Otter, 2000). Relevant disciplines for integrated water management include sciences related to the natural system, such as hydrology, morphology, ecology, meteorology and geography, as well as sciences related to the social system, such as economics, spatial planning, sociology and policy sciences (Karstens, 2009). Thus, while this research is rooted in social sciences, it aims to provide relevant insights for a professional domain that encompasses a wide variety of disciplines.

Social scientists produce a different type of knowledge than natural scientists or engineers. Traditionally, the water management domain is dominated by productive knowledge or techne. This type of knowledge concerns the application of technical knowledge and skills and involves the creation of pragmatic and context-dependent knowledge. It is oriented towards production and guided by a clear goal. The concept of techne is based on a contemporary interpretation of work by Aristotle who argued that there are three intellectual virtues: episteme (theoretical knowledge), techne (productive knowledge) and phronesis (practical knowledge). Natural sciences are the strongest in producing universal theories that can explain or predict, i.e. theoretical knowledge. Social sciences, on the other hand, are weak at producing universal theories but strongest in reflexive analysis and discussion of values and interests, i.e. practical knowledge. While natural sciences involve the study of natural objects, social sciences involve the study of self-reflecting human subjects. They are concerned with the finding of probable, context-dependent explanations rather than universal truths and with the answering of value-laden questions, such as: where are we going, is this desirable, and what should be done? (Flyvbjerg, 2001, 2004). Like several other recent theses in the water management domain (Evers, 2011; Hommes, 2008; van der Molen, 2011; Van Dijk, 2008; Vreugdenhil, 2010), this research is primarily concerned with the production of practical knowledge. How our desire to develop practical knowledge affected the design and execution of this research is explained in the next subsections.

\section{Research design: an iterative case study approach}

Qualitative case study research is used as the main strategy for this research. This very well matches with our desire to develop practical knowledge. While the development of practical knowledge is not driven by a certain method, it certainly benefits from the analysis of concrete cases and contexts (Flyvbjerg, 2001). In-depth case studies are commonly used 
in studies focusing on the human aspects of water management, since case studies are good at embracing complexity and context-specificity (Pahl-Wostl \& Kranz, 2010). Also evaluation research often relies on qualitative case studies. Besides that cases can help to describe an intervention and its context or illustrate certain aspects of an intervention, they can also help to explain 'real-life interventions' and to provide insights in produced outcomes (Yin, 2009). The cases that are central in this research are all studied real time. In comparison with retrospective studies, real time studies have the disadvantage of not knowing the process and outcomes beforehand. Therefore, we could not select cases that represent a typical success or failure. To study cases real time also has important advantages: it avoids bias that may lead to filtering out evidence that contradicts an initial assessment and helps to identify short-lived factors or changes that tend to be forgotten (Van de Ven, 2007). Furthermore, it allows a researcher to be close to the phenomena under study and therefore benefits the production of practical knowledge (Flyvbjerg, 2001).

The focus of this research is on projects that are relatively similar. All cases are flood risk management problems that are implemented with Dutch support in the Romanian context. An important reason for selecting similar projects is that this enables the gathering of knowledge about the small, local context that gives a project its immediate meaning and the larger, international context that indicates the general significance of the project. Such knowledge of concrete circumstances and conditions is an important ingredient in the development of practical knowledge (Flyvbjerg, 2004). In addition, the selection of relatively similar projects eases case comparison, and therefore promotes the development of more general insights. We selected the Romanian context for two reasons. Firstly, a considerable number of Dutch-funded projects were implemented in this country in the past few years. Secondly, there were opportunities to be closely involved in several of these projects. As there were quite a few projects focusing on flood risk management, we decided to concentrate on projects in this domain. Additionally, flood risk management projects compared to water technology projects - are embedded in a more complex structural context, since they occur at the interface of land and water management. Moreover, it is one of the sectors for which the Dutch water sector is internationally very well-known. In Chapter 8 , we discuss whether the results of the cases also apply to other Dutch-funded water projects and to knowledge transfer projects in general.

When developing practical knowledge, the testing of general theories in specific cases (deduction) and the development of general theories on the basis of specific cases (induction) are both not very suitable approaches. It rather requires an approach that focuses on the iteration between general concepts (theory) and actual phenomena (practice) (Van Dijk, 2008). Such an approach, that leaves space for discovery, is often referred to as abduction. It involves that a researcher adopts a flexible attitude towards the connection between theory and data (Van Maanen et al., 2007). In this research, such flexibility was achieved by complementing our basic theoretical framework with new theoretical concepts. 
The use of similar theoretical concepts eased comparison whereas the adding of theoretical concepts deepened our understanding of the cases. Table 1.1 provides an overview of how cases were connected to theoretical concepts and presents all research activities and related results in chronological order.

Table 1.1 - Chronological overview of research activities and related results

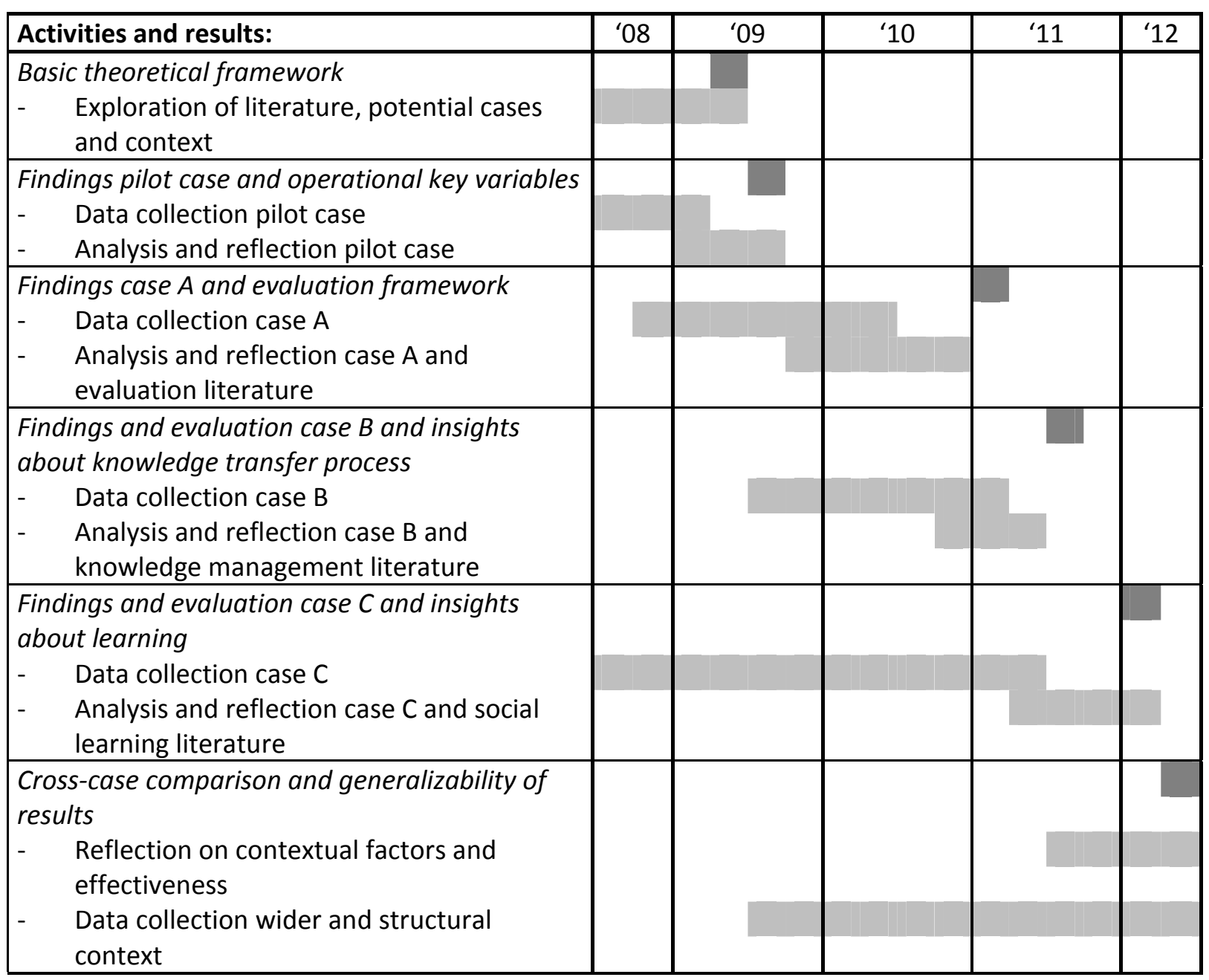

The conceptual basis of all case studies is formed by the variables of the Contextual Interaction Theory: context, interactive process and actor characteristics. This conceptual lens was first applied to a pilot case that was studied in retrospective (Vinke-de Kruijf, 2009b). The experiences of this case were used to make the core variables of the theory operational for the cases under study and used as a basis for the first real time case, the project "Room for the River in Cat's bend, Romania" (case A). In the analysis of this case, evaluation literature and case study experiences are used in the development of an evaluation framework (Chapter 3). The same evaluation framework was later applied to two subsequent cases and used to compare the cases (Chapter 7). The knowledge transfer process is central in the second real time case, the project "Pilot implementation of the Flood Information and Warning System (FLIWAS) in the Banat region, Romania" (case 
B). Knowledge management literature is used to reflect upon the case study experiences to gain more insight in the role of actors, their interaction and knowledge (Chapter 4). In the analysis of the third real time case, the project "Integrated Water Management for the Tecucel River basin" (case C), the focus is on the role of social learning to better understand how actor characteristics change over time (Chapter 5). The analyses of the Romanian context and the case studies are used to draw more general conclusions on the role of contextual factors (Chapter 6). The connections between the cases and the literature are the result of an iterative process. We had certain topics in mind that we wanted to elaborate further and used the case study experiences to actually connect certain cases to certain theories. To reflect upon the meaning of effectiveness is an obvious starting-point and therefore central in the first case. The sharing and acquisition of knowledge was an important component of the technical-oriented second case. Hence, it was logical to reflect upon the transfer of knowledge in this case. We reflected upon learning in the third case study since we had more longitudinal data of this case due to its relatively long duration. The next section explains how data were collected and analysed.

\section{Data collection and analysis}

This research is rooted in an interpretative tradition, which means that data are not perceived as objective givens but as things that $\mathrm{I}$ - the author of this thesis who collected and analysed most data - observed and made sense of the meanings and interactions of others. Reflection on the role of the researcher in doing so is an important characteristic of interpretative studies (Yanow \& Schwartz-Shea, 2006). Research as a process of sensemaking also raises important philosophical questions: is it possible to understand others who are different and what does such understanding involve? (Fay, 1996). My position is that the development of practical knowledge is not a quest for universal and unambiguous truths. It is rather about making a contribution to an on-going dialogue and about the development of credible and useful findings: educated guesses and suggestions about 'how things may be' (Flyvbjerg, 2004; Van Dijk, 2008). In the development of such knowledge, interaction with participants plays a key role (Cutcliffe \& McKenna, 2002). This subsection first provides a brief overview of how data were collected, analysed and reported. Subsequently, it explains how my involvement as a researcher and interaction with others may have influenced the results of this research.

Research data were mostly collected by the author (sometimes in collaboration with others) using qualitative methods including document analysis, semi-structured interviews and direct observation. For the document analysis, I collected government documents (such as policies and legislation), project documentation (such as work plans, presentations, letters, minutes and brochures) and online material (such as newsletter articles and websites of organizations). As I am a native Dutch speaker and acquired reasonable knowledge of the Romanian language, I had no problem in understanding Dutch and Romanian documents. 
Semi-structured interviews were conducted - if necessary with the assistance of a translator - with a wide variety of Dutch and Romanian persons who were either involved in one of the case study projects or had relevant knowledge about the Dutch and/or Romanian water sector (see Annex I for an overview). All Dutch respondents were interviewed in Dutch. The interviews were conducted mostly face-to-face and sometimes by phone. I took detailed notes of each interview on the basis of which I produced an interview report. These reports were sent to interviewees for verification and feedback. Interviews with Romanian actors were executed in English (directly or with the assistance of a translator). Also because until 1990 wiretapping practices by the secret police agency used to be widespread, I chose not to record any of the interviews but to take notes instead. If possible, interview reports were cross-checked with the interviewee or, in some cases, with the translator. Data were furthermore collected by means of direct observation. I attended as many workshops and meetings as possible and regularly discussed the project with actors involved, also to verify my findings. In the first case, I collaborated with a Romanian co-observer with whom I also discussed my observations and findings. To gain more insight in the structural context for flood risk management, I also prepared - in collaboration with a Romanian student - a questionnaire for experts of regional Romanian water authorities.

Most collected data were analysed with a programme for qualitative data analysis (Atlas.ti). This programme can be used to find patterns and relations between data (see e.g. Friese, 2011) but I mainly used the programme's database function for easy access of data and its coding function for structuring data. In the development of practical knowledge, the preparation of detailed narratives with descriptions and interpretations of a phenomenon play an important role (Flyvbjerg, 2001). In interpretative research, these narratives are commonly referred to as 'thick descriptions', which are descriptions that capture contextspecific nuances by presenting events, persons or interactions in sufficient detail (Yanow \& Schwartz-Shea, 2006, p. 101). The data presented in this thesis is based on such thick descriptions, which are laid down in various research reports: a theoretical framework (Vinke-de Kruijf, 2009a), a pilot case study (Vinke-de Kruijf, 2009b) and three in-depth case studies (Vinke-de Kruijf, 2011a, 2011b, 2012). These reports also present detailed information about the research process and how data were collected.

The presence and perceptions of a researcher and any personal changes in a researcher are likely to impact research findings (Patton, 1999). My role in all cases was an observatory one: I was not a member of the project team and therefore not in the position to manipulate events. While my presence may have affected the behaviour of the actors involved, I have no reasons to believe that my involvement led to any substantial adjustment in the course and outcomes of the case studies. Especially when I observed meetings and workshops, I had the impression that participants nearly forgot that they were observed. What could have been rather influential was that I interviewed participants once a project was finished. Following an interview, they sometimes decided to initiate an action that would enable 
follow-up. However, I have no indication that this also resulted in actual follow-up. As regards my own predispositions and biases, I had no concrete expectations about the case studies. Before I started this research, I had never been involved in international activities of the Dutch water sector. I also had no specific knowledge of or connection with Romania. Since I lived in Romania when collecting case study data, I experienced - physical, emotional and intellectual - the Romanian context in which the projects are embedded, and therefore developed new understandings of the Romanian context. During my research, I further gradually transformed from a layperson into an expert. In particular in informal meetings, I was regularly asked to share my knowledge and insights. This probably enlightened project participants but I have no indication that my knowledge was used to substantially change any of the studied projects.

In the entire research process, my interaction with others played an important role. To ensure that I interpreted data correctly, I asked interviewees for feedback on the interview reports. Further, I regularly discussed my findings with those involved in the case study projects and asked them to review case study reports. I also discussed my ideas and findings with persons involved in the export of Dutch water management or in water management in Romania (e.g. during interviews, in formal and informal meetings and at seminars and conferences). My regular interactions with practitioners appeared to be very productive, providing easy access to data. These interactions also taught me how I evaluated my findings compared to others, and therefore to improve my interpretations.

\subsection{Outline}

This thesis consists of: (1) an introductory part explaining the context of the studied projects; (2) a part with individual case studies; and (3) a reflecting part that includes crosscase comparisons. Figure 1.4 provides an overview of the chapters in this thesis. Chapter 1 of this thesis introduces the research background and objective and explains the main theoretical concepts and methods used. Chapter 2 provides a general introduction into the wider and structural context for flood risk management in Romania. For this, it reflects upon ideas about governance and recent developments on flood risk management in a European context. The three subsequent chapters elaborate elements of our theoretical framework in relation to one of the case studies. Central in Chapter 3 is the evaluation of transfer projects. It introduces an evaluation framework and applies this to the project 'Room for the River in Cat's bend, Romania'. Chapter 4 reflects on the knowledge transfer process and uses the project 'Pilot implementation of FLIWAS in Banat region, Romania' as case. The role of learning in such international knowledge transfer projects is reflected upon in Chapter 5, using the project 'Integrated Water Management in the Tecucel River basin' as case. The experiences of all three cases are used in Chapter 6 to reflect upon how contextual factors influence the effectiveness of knowledge transfer projects. Chapter 7 uses the evaluation framework that was introduced in Chapter 3 to compare the 
effectiveness of the cases. Theoretical and methodological reflections are central in Chapter 8. The chapter discusses the use and applicability of the Contextual Interaction Theory as conceptual lens, the evaluation framework and the generalizability of the results. Each of the chapters answers part of our research questions. The first question about effectiveness is answered in the Chapters 3 and 7. The second question about dynamic interaction is answered in the Chapters 4 and 5. The Chapters 2, 6 and 8 answer the third question about contextual factors and generalizability. The findings of these chapters are synthesized in a concluding chapter, chapter 9. The concluding chapter answers the research questions and provides recommendations for practitioners and further research.

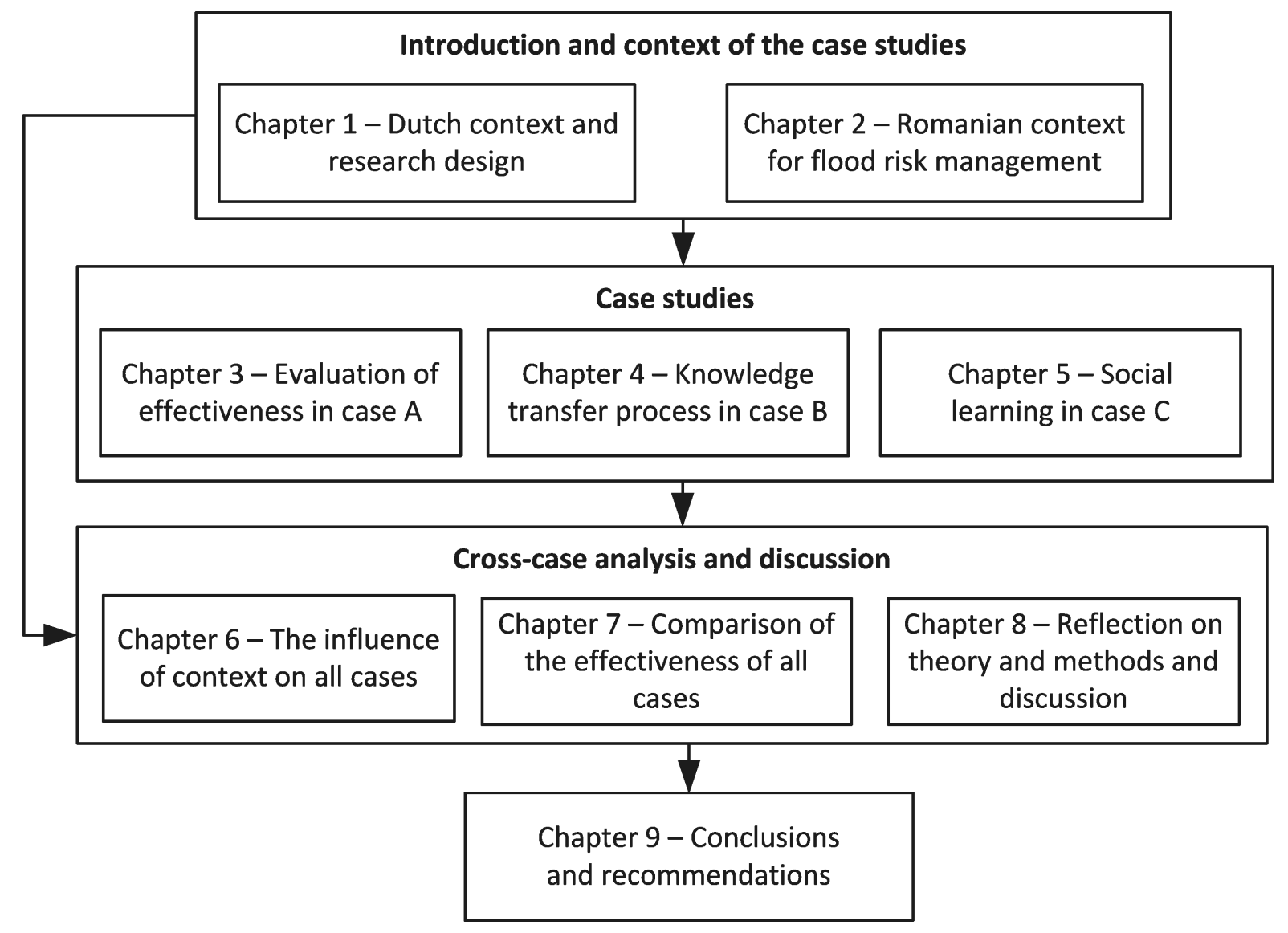

Figure 1.4 - Outline of the thesis 


\title{
Chapter 2
}

\section{The Romanian context for flood risk management}

This chapter introduces the governance context of the projects that are studied in this thesis. Another version of this chapter has been submitted for publication as "Flood problems from a governance perspective: an assessment of flood risk governance in Romania" by Vinkede Kruijf, J., Kuks, S. M. M., \& Augustijn, D. C. M.

\begin{abstract}
Building on an existing model of governance, this chapter provides an assessment of flood risk governance in Romania. A governance structure supports the solving of flood risk management problems when it regulates all relevant levels, actors, perceptions, strategies and resources (high extent) and has connections between these various dimensions (high coherence). In the case of Romania, both extent and coherence have increased since the fall of the communist regime. Policies have changed, but the actual inclusion of actors, strategies and perceptions is lagging behind. Various measures were introduced improving coherence, but there is no indication that actors also actively look for integration or synergy. Additional efforts are needed arrive at a more supportive governance structure for flood risk management.
\end{abstract}

\subsection{Introduction}

In recent decades, the capacity of countries to deal with flood risks has been growing. Despite this progress, more people and economic assets are exposed to flood risks. In particular, the populations of countries with low incomes and weak governance continue to face a high risk of being killed by floods (UNISDR, 2011). In Europe, flooding is currently the most common natural disaster. Between 1998 and 2009, 213 flood events were recorded causing 1127 deaths and affecting more than three million people (about 0.5 per cent of the total population). Romania, which is the country focused on in this chapter, is among the three most affected European countries (EEA, 2010b). Due to climate change impacts, the frequency of floods is likely to increase further in many European river basins, particularly in Central and Eastern Europe (EEA, 2010a). In response to these developments, flood risk management was given special attention in the past decade by international organizations 
and at international forums and new international organizations were established (Samuels, et al., 2006; WMO, 2009). At the European level, guidelines for sustainable flood prevention (UNECE, 2000) and a European flood action plan were developed, which resulted in a directive on flood risk management (EU FD) (EC, 2007). What these recent policy documents and literature have in common is that they recognize the need to adopt an integrated approach for flood management (cf. De Bruijn, et al., 2007; Samuels, et al., 2006; Schanze, 2006).

Governance is becoming an increasingly popular concept in a water management context. At the Second World Water Forum, the Global Water Partnership (GWP) observed that water problems are essentially governance problems (GWP, 2000). Since then, numerous reports of international organizations reiterated that the 'water crisis' - the occurrence of floods and droughts and problems of water allocation, quality and use - is a governance crisis (cf. OECD, 2011; UN-Water, 2006). This means that water problems are often caused by a lack of collaboration and capacity, weak institutional and regulatory frameworks and poor financial management. Hence, international organizations argue that improving water governance is the key to more effective water management (GWP, 2000; OECD, 2011) and that disaster risks can only be reduced once governance arrangements are improved (UNISDR, 2011). In most of these reports, governance is associated with normative ideas about 'good governance' such as transparency, inclusiveness, efficiency and accountability (Rogers \& Hall, 2003). In this chapter, governance is used in a more neutral way and seen as the institutional setting in which diverse actors at multiple levels act and interact (Bressers \& Kuks, 2013).

The central question of this chapter is: To what degree do the extent and coherence of Romania's governance structure support the management of flood risks? To answer this question, we build upon an existing model of governance, which has been used in various studies (for an overview, see De Boer \& Bressers, 2011), including a study focusing on the reorganization of the water services sector in Romania (Vinke-de Kruijf et al., 2009). Recently, a start was made to also develop the model into an assessment tool, which assists policy makers in identifying the opportunities and threads for policy implementation (Kuks et al., 2012). This chapter contributes to the further development of this assessment tool by making the model operational for flood risk management. The model is applied to the case of inland flooding in Romania. The next section of this chapter describes the governance model and elaborates the framework and methods that we used in assessing flood risk governance in Romania. Since governance is intrinsically connected to the wider political, economic, technological, cultural and problem contexts of a country (De Boer \& Bressers, 2011), section 2.3 introduces the wider Romanian setting for flood risk management. Section 2.4 presents the governance structure in place for flood risk management. Section 2.5 discusses the extent and coherence of the governance structure in Romania. The last section summarizes our main conclusions. 


\subsection{Assessment framework and methods}

\section{Dimensions of flood risk governance}

For the assessment of flood risk governance in Romania, we build upon a model of governance that was developed by Bressers and Kuks (2003) to assess the sustainability of governance structures in relation to the implementation of the EU Water Framework Directive. The model describes a governance structure in terms of five dimensions: (1) levels and scales; (2) actors in the policy network; (3) problem perceptions and goal ambitions; (4) strategies and instruments; and (5) responsibilities and resources (Bressers \& Kuks, 2003, 2013, 2004). The second column of Table 2.1 provides the descriptive questions that are associated with these dimensions. The starting-point of the model is that the concept of 'governance' is basically a modification and extension of the concept of 'public policy'. Policies aim at solving or mitigating public problems. They specify the policy goals and which actors will try to achieve them with what kind of resources and instruments (Fischer, 1995). These policies are based upon problem perceptions rather than on objective givens (Dery, 1984). Since resources are spread across the policy network, problems are solved in interaction between mutually dependent actors, both public and private, at the transnational, national, regional and local level (Bressers \& Kuks, 2003; Koppenjan \& Klijn, 2004; Peters \& Pierre, 1998, 2001). Thus, governance involves various responsible actors at multiple levels, who tend to have diverse problem perceptions and can employ various instruments. In this chapter, we make the five governance dimensions operational for the flood risk management domain. In doing so, we take the EU Floods Directive (FD), which guides the implementation of flood risk management in Europe, as a starting-point. We illustrate these guidelines with insights from the literature and publications of international organizations and institutions.

Levels and scales: As hydrological and administrative boundaries seldom coincide, flood management inevitably asks for cooperation and coordination across administrative boundaries (WMO, 2009). The EU FD advocates the management of flood risks at the level of entire river basins. In case of an international basin, countries can confine their plans to the portion of the basin inside their own country but they should ensure the exchange of relevant information, exclude measures that increase flood risks upstream or downstream (unless an agreement is reached), endeavour the production of a single management plan and, in as far as possible, coordinate plans at an international level (EC, 2007). In many countries, cooperation between authorities at the national, regional and local levels needs to be improved for the implementation of policies (Van Alphen \& Lodder, 2006).

Actors in the policy network: Flood risk management involves a wide variety of actors who represent not only various levels but also various domains (Schanze, 2006). The EU FD requires authorities to consider all relevant users and to coordinate among these actors. It especially asks for coordination with the EU Water Framework Directive (also when 
implemented by different authorities) and for taking into account the entire flood management cycle (i.e. prevention, protection and preparedness) and other domains, such as nature conservation, navigation and spatial planning. The FD further promotes the active involvement of interested parties and asks to make relevant information available to the public (EC, 2007). Public opposition currently delays flood risk policy implementation in many countries. This can be prevented by involving stakeholders in an early stage and awareness raising (Van Alphen \& Lodder, 2006).

Problem perceptions and goal ambitions: Given their local and regional circumstances, the EU FD asks countries to determine what objectives are appropriate while considering environmental objectives, socio-economic aspects and the likely impacts of climate change. They need to review and, if necessary, update these objectives every six years (EC, 2007). This approach differs from traditional flood management, which was largely focused on defence, protection and control measures. Countries are now urged to adopt an approach that is based on an on-going and comprehensive assessment of flood risks. What challenges the formulation of objectives is that they are not only context-specific but also actorspecific. Actors have different, and sometimes conflicting, priorities (Samuels, et al., 2006), different expectations about natural and social developments (Hooijer et al., 2004) and different risk perceptions (Baan \& Klijn, 2004).

Strategies and instruments: Strategies for flood risk management can be classified into two broad categories: (1) flood prevention through better land use management or control measures; and (2) mitigation (i.e. the reduction of potential damage) through adaptive land use, forecasting and warning systems, education, emergency planning and the like (Hooijer, et al., 2004). The EU FD asks countries to consider multiple strategies and to include prevention, protection and preparedness measures. It specifically asks countries to also consider measures that provide more space to the river (e.g. restoration of floodplains) as well as measures that prevent and reduce damage to human activities (EC, 2007). One of the challenges in the preparation of strategies is that they are drafted for systems that are dynamic and inherently uncertain. Hence, strategies are preferably robust, i.e. remain effective in a large range of circumstances, and resilient, i.e. take into account a wide range of discharges (De Bruijn, et al., 2007). Although the EU FD does not explicitly mention the need for such strategies, it urges countries to take into account long-term developments and the potential impacts of climate change, which are both uncertain. The directive is not explicit about what instruments should be employed by countries (EC, 2007). Research shows that it is more effective to combine various instruments (i.e. technical measures, regulation, financial instruments and communicative instruments) than to focus on one (Hooijer, et al., 2004).

Responsibilities and resources: The EU FD asks for coordination to overcome fragmentation and asks countries to gather information about floods that occurred in the past, identify areas with a high risk of flooding and also to prepare flood hazard maps and 
flood risk maps (EC, 2007). Until recently, most of the European countries already had some maps, but most of them did not yet have risk maps (De Moel et al., 2009). In most countries, diverse institutions are responsible for policy development and for operational management. They face problems related to the inadequate legislation on floodplain management, unclear distinction between state and local waters, lack of finances for maintenance and insufficient skilled staff (Van Alphen \& Lodder, 2006).

\section{Towards an assessment tool for flood risk governance}

Previous research shows that governance is supportive of sustainable water management when it combines a high extent with a high coherence (Bressers \& Kuks, 2004). Extent refers here to the completeness of a structure: does it take all relevant uses and users into account? Coherence points towards the connections within and between various dimensions: do various dimensions strengthen rather than weaken each other? Structures that are incomplete (i.e. leave some domains unregulated) and incoherent (fail to recognize mutual dependencies between various domains and actors) are likely to result in deterioration of the water resources or provided services (De Boer \& Bressers, 2011). Generally speaking, water governance structures have the tendency to include more uses and users. When they become more complete, they also tend to become more complex due to the inclusion of more levels, actors, perceptions and instruments. Once structures become more complex, the need for coherence - i.e. connections between and within various dimensions - also increases. Coherent governance involves, among others, that actors involved are aware of their mutual dependencies and interact with each other, that the existence of multiple problem definitions is taken into account in strategies and objectives, and that responsibilities are accompanied by resources for implementation. While the extension of governance dimensions is a rather straightforward development, increased coherence is not, but requires deliberate efforts. As a result, many contemporary water governance structures combine a high extent with a low coherence and are therefore examples of fragmented rather than integrated structures (Bressers \& Kuks, 2004). The last three columns of Table 2.1 provide definitions of high extent and high coherence and specific points of attention for the assessment of flood risk governance.

\section{Data and methods}

Data about flood risk governance were collected through document analysis, interviews, a questionnaire and observations. We analysed a wide variety of written material including policies, plans, legislation, newspaper articles and literature. We undertook semi-structured interviews with various persons with a role in flood risk management, including a national policy maker, ten experts at three different water management authorities and two representatives of non-governmental organizations. On the basis of the document analysis and the interviews, we designed a questionnaire for operational managers. The 
questionnaire included questions about the causes behind flood risk problems (relative importance of 23 causes), strategies and instruments (used, applied and planned), communication with other actors (how often and what means), participation (degree and information sharing), international collaboration (communication and collaboration) and resources for implementation (availability of information, finances, legal framework, expertise and authority). The questionnaire included both open-ended questions (e.g. the year and scale of maps in use or available funds) and different types of closed-ended questions. The questionnaire was prepared and distributed in collaboration with an MSc student of the 'Gheorghe Asachi' Technical University of Iaşi, Romania among the managers of the departments responsible for flood risk information and management (operational managers) at eleven regional water authorities (all questionnaires were filled out). We analysed the results using excel. This assessment is further based on observations of the first author, who was involved as a researcher in local projects, meetings and workshops focusing on flood risk management between 2008 and 2011 (Vinke-de Kruijf, 2009b, 2011a, 2011b, 2012). 
Table 2.1 - Key questions for the description and assessment of a flood risk governance structure (adapted after Kuks, et al., 2012)

\begin{tabular}{|c|c|c|c|c|}
\hline Dimension & Descriptive question & High extent & High coherence & $\begin{array}{l}\text { Specific attention points and questions for the } \\
\text { assessment of flood risk governance }\end{array}$ \\
\hline Levels and scales & $\begin{array}{l}\text { Which levels dominate } \\
\text { and are involved? }\end{array}$ & $\begin{array}{l}\text { All relevant levels are } \\
\text { included }\end{array}$ & $\begin{array}{l}\text { Levels collaborate and } \\
\text { trust each other }\end{array}$ & $\begin{array}{l}\text { Do plans consider the entire river basin, including } \\
\text { upstream and downstream relations? Do local, regional, } \\
\text { basin and national actors communicate and cooperate } \\
\text { with each other? If applicable, are there structures for } \\
\text { international cooperation? }\end{array}$ \\
\hline $\begin{array}{l}\text { Actors in the policy } \\
\text { network }\end{array}$ & $\begin{array}{l}\text { Which actors are } \\
\text { included and excluded? }\end{array}$ & $\begin{array}{l}\text { All relevant actors of } \\
\text { various domains are } \\
\text { included }\end{array}$ & $\begin{array}{l}\text { Interactions between } \\
\text { actors in the policy } \\
\text { network are supported } \\
\text { and existing }\end{array}$ & $\begin{array}{l}\text { Do flood managers coordinate their actions with other } \\
\text { domains? Do actors responsible for prevention, } \\
\text { protection and preparedness interact with each other? } \\
\text { Are interested parties given the possibility to } \\
\text { participate in policy making or, at least, informed? }\end{array}$ \\
\hline $\begin{array}{l}\text { Problem } \\
\text { perceptions and } \\
\text { goal ambitions }\end{array}$ & $\begin{array}{l}\text { Which problem } \\
\text { perspectives are taken } \\
\text { into account? }\end{array}$ & $\begin{array}{l}\text { Various problem } \\
\text { perspectives are } \\
\text { included }\end{array}$ & $\begin{array}{l}\text { Various goals support } \\
\text { and do not contradict } \\
\text { each other }\end{array}$ & $\begin{array}{l}\text { Are objectives based on comprehensive risk } \\
\text { assessments, maps and plans? Do objectives fit the } \\
\text { specific context for flood risk management? Are } \\
\text { environmental and socio-economic aspects and impacts } \\
\text { of climate change considered? }\end{array}$ \\
\hline $\begin{array}{l}\text { Strategies and } \\
\text { instruments }\end{array}$ & $\begin{array}{l}\text { What types of } \\
\text { instruments are } \\
\text { included in the } \\
\text { strategy? }\end{array}$ & $\begin{array}{l}\text { Various types of } \\
\text { relevant instruments } \\
\text { are included }\end{array}$ & $\begin{array}{l}\text { Strategies are } \\
\text { encompassing and } \\
\text { include a synergy-based } \\
\text { incentive system }\end{array}$ & $\begin{array}{l}\text { Do plans pay attention to prevention, protection and } \\
\text { preparedness? Are measures that provide more space } \\
\text { to the river and other prevention measures considered? } \\
\text { Are non-structural measures taken into account? Are } \\
\text { plans based on a variety of instruments? }\end{array}$ \\
\hline $\begin{array}{l}\text { Responsibilities } \\
\text { and resources }\end{array}$ & $\begin{array}{l}\text { How are } \\
\text { responsibilities } \\
\text { assigned and what } \\
\text { resources are } \\
\text { available? }\end{array}$ & $\begin{array}{l}\text { Resources are } \\
\text { included in the } \\
\text { assignment of } \\
\text { responsibilities }\end{array}$ & $\begin{array}{l}\text { Assigned responsibilities } \\
\text { enhance collaboration }\end{array}$ & $\begin{array}{l}\text { Do responsible actors coordinate their actions? Do } \\
\text { flood managers have access to resources including } \\
\text { adequate information, financial resources and } \\
\text { personnel? Is floodplain management well arranged by } \\
\text { law? }\end{array}$ \\
\hline
\end{tabular}




\subsection{Romanian setting for flood risk management}

\section{Introduction of the Romanian context}

Between the Second World War and 1989, Romania was - like many countries in Central and Southeast Europe - ruled by a communist regime. In this period, institutions were nationalized, agriculture was collectivized, private landownership abolished and the market economy was replaced by central planning. Also education was reorganized, history rewritten and a powerful internal security service was established to maintain order (Light, 2006). Following a revolution, which led to the collapse of this regime, a gradual transition towards a pluralistic political and economic system began. This process was and is strongly influenced by external forces that seek to integrate the country into a mainstream, international system. Romania's adherence to the European Union (EU) has played a key role in this process (Gallagher, 2005). Soon after the revolution, a trade and cooperation agreement with the EU was signed and asssistance programmes were started. In 1995 - the year that the EU launched its pre-accession strategy for Central and Eastern European countries - the country applied for EU membership. This formally also involved that Romania had to feature stable political and legal institutions, a functioning market economy and to adopt the acquis communautaire (i.e. rules and legislations that were adopted by the EU member states in various policy fields). Even though observers noticed that the country was reforming at a slow pace and not meeting all necessary conditions and requirements, accession negotiations started in 2000 and were closed in 2004. When Romania accessed the EU on the $1^{\text {st }}$ of January 2007, there were still a range of areas where further efforts in implementing and enforcing the acquis was needed (Phinnemore, 2010).

For most new EU members, compliance with the environmental acquis is rather challenging. As the environment had never been high on the agenda before, major investments are needed to bring environmental infrastructure in line with EU standards. This challenges the financial and administrative capacity of these countries. In addition, there is often limited experience with the implementation of more participatory and integrated approaches that are promoted in various EU guidelines. Although the imposition of EU environmental legislation provides a chance for inclusion of environmental issues on the political agenda of these countries, it can also be problematic. Besides the problem of overload (i.e. countries simply lack the capacity to manage and coordinate the implementation process), countries are also not stimulated to learn about their own domestic needs, restricted in the choice for solutions and to work towards policy integration (Kremlis \& Dusik, 2005; Tews, 2009). In the case of Romania, the attention for environmental issues soon increased after the collapse of the communist regime. Enforcement of environmental legislation and the disappearance of polluters led to reduction of water quality problems. Also the number of non-governmental organizations of which the majority is working on environmental sustainability at the local and regional 
level - increased but is relatively low compared to other Central European countries. Their establishment is driven by compliance with EU standards rather than by bottom-up initiatives and they have limited support, visibility and national impact (Stringer et al., 2009; Teodosiu et al., 2003).

When Romania accessed the EU, huge investments were still needed to bring its environmental infrastructure in line with EU standards. The most important problems include the lack of monitoring systems, poor water quality, insufficient treatment of wastewater, the low connection rate for drinking water and wastewater, the increase of floods and coastal erosion. Especially the improvement of water services currently has priority. The reduction of natural disasters - of which floods are the most important one also has priority but to a lesser extent. Out of the structural funds available for environment, about $60 \%$ is allocated to water services and only $6 \%$ to the reduction of natural risks (of which half for flood risks) (GoR, 2007b). The absorption of these funds has become even more crucial in recent years. While the country was one of Europe's fastest growing economies since 2000, its gross domestic product fell more than $7 \%$ in 2009 as a result of the global economic crisis. This also prompted the government to seek emergency assistance from international lenders (CIA, 2012; Index Mundi, 2011). The actual use of funds is lagging behind and also relatively low in comparison with other countries (Zaman \& Cristea, 2011).

\section{Water management and flood problems}

The majority of Romania (about 97\%) is located in the Danube River basin. About 1075 $\mathrm{km}$ of the Danube River - the lower Danube and the Danube Delta - is flowing through or borders Romania. Two major tributaries, the Siret and the Prut, join the Danube in the country (see Figure 2.1). The first national attempts to manage water resources date back to the end of the nineteenth century. They initially focused on the construction of hydrotechnical works for agricultural purposes (e.g. irrigation, drainage and flood protection) and later also on works for hydropower and navigation. The construction of dikes and dams became even more important during the communist regime. In this period - and especially following the heavy floods in 1970 - most of the flood protection dikes along the Danube River were constructed. In total, about three-quarter of the Danube floodplains in Romania disappeared in the past century. In the fifties, the basis was also laid for the current water governance structure: a state committee was established to coordinate water issues at the national level, river basins were introduced as the main unit for water management and the first river basin management plans were prepared. (BDG, 2008; Vadineanu \& Preda, 2008; WWF Germany, 2009). 


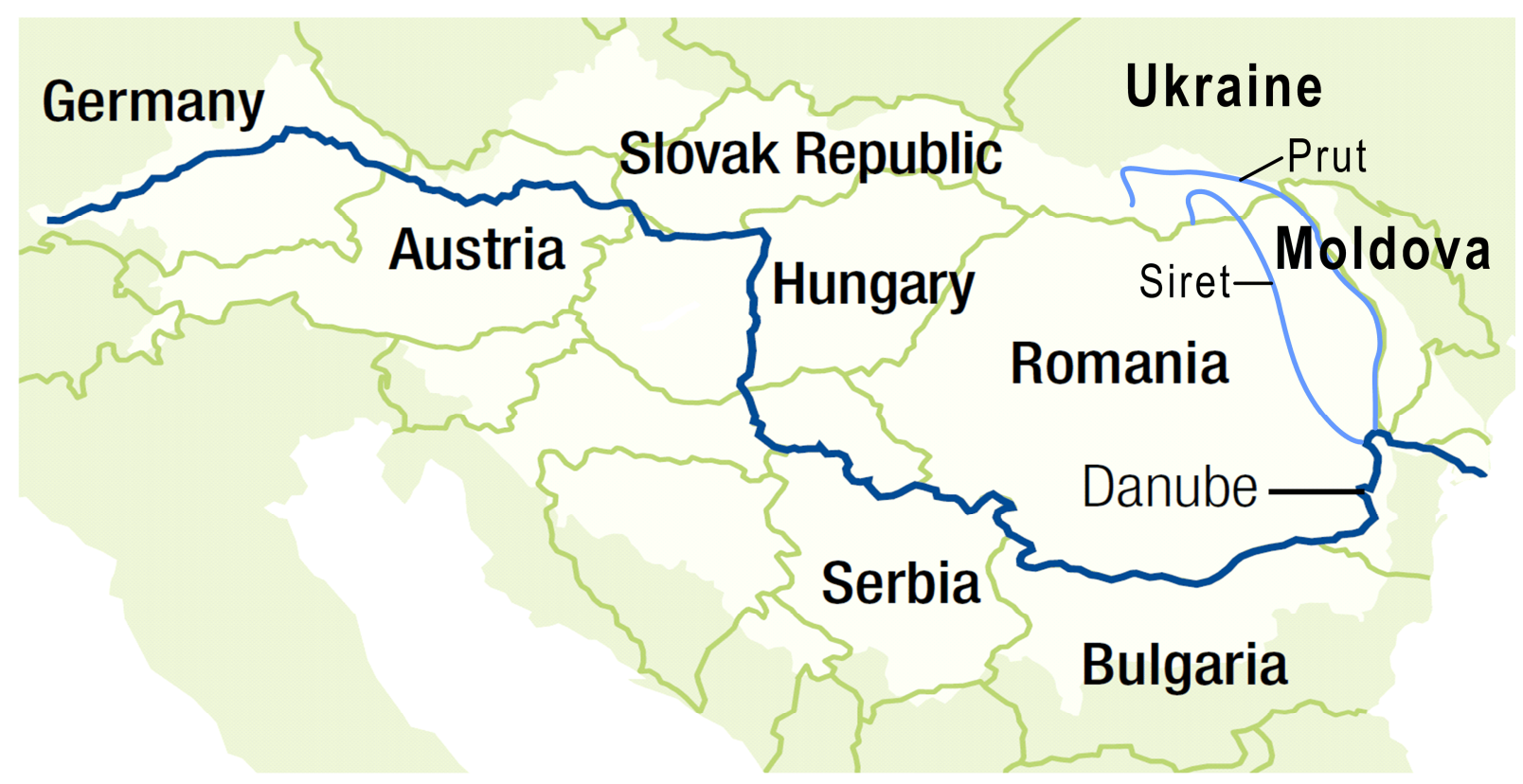

Figure 2.1 - Romania, the Prut River and the Siret River in the Danube River basin (adapted after Wong et al., 2007)

Floods have long been a problem in Romania. They especially happen in mountainous areas during spring and summer, when snow starts to melt and heavy rainfalls regularly occur. The number of floods has been increasing gradually over the past centuries with a sharp increase in the frequency and intensity over the past decades (Serban \& Galie, 2006). In the last decade, floods have become an almost yearly recurring issue. They result from high waters on one of the large rivers or from a sudden rise of the water level in small rivers or streams (flash floods). These floods cause major damage to all kind of economic objects (e.g. roads, dikes, houses, bridges or dams) and affected many people (13 yearly deaths on average between 1969 and 2006) (GoR, 2010). One of the worst recent floods took place in 2005, when high water levels throughout the country affected 1734 communities and caused 76 deaths and about 1.5 billion euro of damage (GoR, 2007b) $)^{1}$. According to the Romanian government, the following factors contributed to the increase of flood risks: intensification of land use, large-scale (illegal) deforestation after 1990, (unauthorized) construction in flood-prone areas, the increase of extreme meteorological events (climate variability that might be the result of climate change) and the poor status of flood protection infrastructure (GoR, 2005b, 2007b). The next section of this chapter discusses the underlying governance problems.

${ }^{1}$ Figures of the EEA (2010b) are slightly different (85 fatalities and $€ 1.2$ billion of economic losses) 


\section{Administrative structure for emergency management}

In Romania, public administration is structured along three levels: national, county (regional) and local (cf. Dragos \& Neamtu, 2007). A wide range of authorities at these various levels plays a role in flood risk management. In 2005, a national system was established that specifies the role of various actors at different levels in the management of emergencies (see Table 2.2). At the national level, general strategies are developed by an inter-ministerial committee. Strategies for specific risks are developed by ministerial committees. At the county level and the local level, policy and decision making is the responsibility of committees with representatives of public authorities, other government agencies and consultants. Operational tasks (e.g. information provision, monitoring and warning) are executed by the General Inspectorate for Emergency Situations (subordinated by the Ministry of Administration and Interior), which has operational units in every county (adapted after Dinica, 2007; Lucaciu, 2005).

The management of environmental emergencies (including floods) is coordinated by the Ministry of Environment and Forests (following the first introduction of a ministry, we use a shorter version of the name). The Ministry of Environment has an Authority for Floods and Water Management (established in 2009) and a Directorate for Flood Risk Management. These actors are involved in the development of a national strategy, coordination, monitoring and international cooperation. The Ministry has under its authority the National Administration for 'Romanian Waters', which is responsible for managing the quality and quantity of water resources. Romanian Waters operates through eleven regional water branches, one for every main sub-basin of the country. These branches are, among others, responsible for (regional) transboundary cooperation and flood protection infrastructure and play a key role in the management of water-related emergencies (e.g. provision and analysis of data and technical support). Operational tasks of Romanian Waters are executed by units at the county level. One of the tasks of these units is to assist local and regional public administrations in the development of emergency plans. Two other actors with a role in flood risk management are the Meteorological Institute and the Institute for Hydrology and Water Management (under the authority of Romanian Waters). These institutes are, among others, responsible for measurements, forecasts and warning (adapted after Dinica, 2007; Lucaciu, 2005). A wide variety of additional national actors is somehow involved in flood risk management. For example, the Ministry of Transport and Infrastructure is responsible for navigation and therefore involved in the maintenance of inland rivers and hydro-technical constructions. The Ministry of Agriculture and Rural Development plays an important role in flood mitigation through its influence on land use and erosion control and also through the ownership of water courses and dikes by its Authority for Irrigation and Drainage. Table 2.2 provides an overview of the main actors involved in flood risk management. 
Table 2.2 - Overview of actors contributing to flood risk management (based on GoR, 2005b, 2010).

\begin{tabular}{|c|c|}
\hline \multicolumn{2}{|c|}{ Emergency management (Ministry of Administration and Interior) } \\
\hline $\begin{array}{l}\text { Inter-ministerial committee (general strategy) and } \\
\text { ministerial committees (specific strategies) }\end{array}$ & Policy making (national) \\
\hline $\begin{array}{l}\text { County committee, including representatives of the } \\
\text { prefect, county council and government agencies }\end{array}$ & Policy making and planning (county) \\
\hline $\begin{array}{l}\text { Local committee, including the mayor, vice-mayor } \\
\text { and other experts }\end{array}$ & $\begin{array}{l}\text { Planning and coordination of volunteers } \\
\text { (local) }\end{array}$ \\
\hline $\begin{array}{l}\text { General inspectorate, operating through county } \\
\text { inspectorates }\end{array}$ & $\begin{array}{l}\text { Monitoring, warning, informing, } \\
\text { coordinating and controlling (national and } \\
\text { county) }\end{array}$ \\
\hline \multicolumn{2}{|c|}{ Flood risk management (Ministry of Environment and Forests) } \\
\hline $\begin{array}{l}\text { Ministry, including the Authority for Floods and } \\
\text { Water Management and the Directorate for Flood } \\
\text { Risk Management }\end{array}$ & $\begin{array}{l}\text { Policy making and coordination, } \\
\text { monitoring and international cooperation } \\
\text { (national) }\end{array}$ \\
\hline $\begin{array}{l}\text { National Administration for 'Romanian Waters', } \\
\text { operating through eleven regional branches, } \\
\text { including operational units at the county level. }\end{array}$ & $\begin{array}{l}\text { Policy implementation, providing data and } \\
\text { technical support, transboundary } \\
\text { cooperation (national, basin and county) }\end{array}$ \\
\hline $\begin{array}{l}\text { Meteorological Institute and the Institute for } \\
\text { Hydrology and Water Management }\end{array}$ & $\begin{array}{l}\text { Measurements, information, forecasts and } \\
\text { warning (national) }\end{array}$ \\
\hline \multicolumn{2}{|c|}{ Other actors who contribute to flood risk and emergency management } \\
\hline \multicolumn{2}{|c|}{$\begin{array}{ll}\text { - } & \text { Ministry of Agriculture, including agencies responsible for forests } \\
\text { - } & \text { Mrainage (sustainable land use and maintenance of infrastructure } \\
\text { Ministry of Transport, including an administration responsible for } \\
\text { - } \quad \text { Ministry of Economy, including a company for hydropower (main } \\
\text { - } \\
\text { hydraulic infrastructure) } \\
\text { - } \quad \text { Ministry of Health, including agencies (water quality monitoring) } \\
\text { - } \quad \text { Ministry of Education (research and education) }\end{array}$} \\
\hline
\end{tabular}

\section{Flood risk management policies and plans}

Until recently, the Romanian government had no specific strategies or plans for flood risk management. This changed shortly after the devastating floods in 2005. It was concluded that one of the problems was the lack of a coherent strategy. In response to the flood events and to comply with the EU FD, the government approved a National Programme that forms the basis for the realization and financing of a plan for flood risk management (GoR, 2005a). The programme consists of a development phase (December 2005 - December 
2009) and an implementation phase (2006-2021). The development phase involves the elaboration of flood risk management plans for each river basin. The main outcomes of this phase are hazard maps and a list of potential measures. For the implementation phase, a distinction is made between urgently needed infrastructural investments in two basins on the short-term (2006-2009) and measures that will be implemented on the medium-term (2009-2015) and the long-term (2015-2021) (GoR, 2005a). To guide the development and implementation of this National Programme, the government elaborated two National Strategies for Flood Risk Management: one for the short-term (GoR, 2005b) and one for the medium and long-term (GoR, 2010).

\subsection{Governance assessment for Romanian flood risk management}

\section{Levels and scales}

Romanian policies for flood risk management are basically developed at the national level, under influence of EU and Danube basin policies, and further elaborated and implemented at the sub-basin level. Within the context of the national programme for flood risk management, all branches of Romanian Waters recently developed basin plans, on the basis of which the Ministry decided what measures are eligible for funding. This approach differs from what was done before: decisions are no longer based on local measures but on a river basin plan. According to national actors, planning at the basin level will improve safety. From a local perspective, river basin planning is not necessarily attractive. For example, local actors in the Prut basin were disappointed that a measure with high priority at the local level was not approved by national authorities since other measures in the basin had priority (Vinke-de Kruijf, 2012).

Operational managers of Romanian Waters are generally satisfied about their collaboration with actors responsible for emergency management and local authorities. However, the pilot implementation of a flood information and warning system in one of the branches showed that local authorities have less interest to actively contribute to the implementation of such a system (Vinke-de Kruijf, 2011a). In other projects, local authorities were sometimes also unwilling to participate since they had no trust in the process, i.e. that their contribution would be taken into account. This relates to a more general problem, which is that lower levels of government often have little trust in higher levels or management authorities (Van Assche et al., 2011; Vinke-de Kruijf, 2011b). To enhance the involvement of local actors in flood risk management, the new National Strategy proposes to form local flood agencies consisting of volunteers and technical experts. These agencies are expected to play a role in preparing the population for floods as well as the integration of local knowledge into maps and plans and the preparation of damage inventories (GoR, 2010).

International collaboration is relevant for all eleven branches since they all border a neighbouring country. The collaboration with neighbouring countries is based on various 
bilateral agreements. Romania has agreements on transboundary cooperation with: Ukraine (1997 focus on water quality, pollution and water use), Hungary (updated in 2003 to include information exchange and the implementation of the EU Water Framework Directive), Bulgaria (agreement about the management of the Danube River and Black Sea between Ministries in 2004 and a Memorandum of Understanding on accidental pollution), Serbia (collaboration based on an agreement of 1955 with the former Republic of Yugoslavia) and Moldova (agreement of 1986 with the former Soviet Union and specific agreements in 2003 and 2006) (Drapa, 2009; Serban \& Galie, 2006; UNECE, 2009). Of critical importance are the relations with Ukraine and Moldova, which are located upstream of the Rivers Siret and Prut. While operational managers are generally satisfied about their collaboration with these and other neighbouring countries, they also explained that the monitoring system of the Danube River is much better developed than the systems of these rivers. Since both upstream countries do not yet have automated monitoring systems and have relatively few gauging stations, the provision of adequate hydrological data tends to be problematic. Experts of the Prut branch explained that they technically cooperate with Ukraine and Moldova and try to develop joint projects. However, also due to political problems Romania has only a very basic bilateral agreement with Moldova. From Ukraine, water managers do not always receive correct and timely information.

Collaboration in the entire Danube basin is based on the Danube River Protection Convention, which was signed by all fourteen countries with a substantial territory in the basin - of which eight EU countries and six non-EU countries. This Convention aims to ensure the sustainable management of surface and ground waters in the Danube River basin (ICPDR, 1994). In 1998, the convention came into force and the International Commission for the Protection of the Danube River (ICDPR) was established to coordinate the convention's implementation. The ICPDR also functions as coordinating body for the implementation of European directives. Countries in the Danube basin were closely involved in the development of the EU best practice document on flood risk management (predecessor of the EU FD) and the EU FD. The best practice document also formed the basis for the joint Action Programme on Flood Protection in the Danube River basin, which was adopted in 2004. The programme was developed by the ICPDR's expert group on flood protection which consists of national experts of various countries. The programme resulted, among others, in seventeen joint flood action plans for all sub-basins of the Danube in 2009.

Romania currently collaborates internationally through various programmes and projects. The Romanian Ministry of Environment leads 'Danube Floodrisk' that aims at the joint assessment of flood risks (ICPDR, 2012). In 2011, the EU Council adopted an EU Strategy for the Danube Region, which aims at the coordinated development of the basin. The strategy's part on the management of environmental risks is coordinated by Romania and Hungary (INTERACT, 2012). The 'Lower Danube Green Corridor' programme is another example of a programme in which Romania collaborates with neighbouring countries 
(Bulgaria, Moldova and Ukraine) on flood risk management. This programme was initiated in 2000 by the Worldwide Fund for Nature (WWF) and aims to protect and restore former floodplains in order to increase the natural storage capacity of the river. The programme represents one of the first and few attempts to integrate ecological aspects into flood risk management and has been quite successful. After ten years, wetland restoration is lagging behind its initial targets but the programme already resulted in a larger amount of protected areas than foreseen (WWF, 2010).

\section{Actors in the policy network}

The management of flood risks requires not only the collaboration across multiple levels, but also across multiple sectors and domains. Alongside county councils, local councils and citizens, the national strategy lists nine ministries and eight other institutions and administrations with a role in flood risk management (GoR, 2005b, 2010). For the development of the strategy itself, the Ministry of Environment collaborated in particular with the Ministries of Transport and Interior. The inter-ministerial committee for water supports the collaboration between ministries but does not yet include flood risk management. The national strategy therefore proposes to expand the scope of this committee to also include flood risk management (GoR, 2010).

Operational managers generally perceive that other actors, in particular local actors, are not taking sufficient action to prevent flooding. Among the most important factors behind floods are, in their opinion, obstruction of the water course (e.g. by waste or remnants of trees), deforestation, timely receipt of information, cooperation from other authorities and unclear division of tasks and responsibilities. One respondent explained that flood problems are mostly caused by the failing capacity of local actors to maintain water courses and drainage facilities and to prevent obstruction of rivers and illegal construction. Along similar lines, another manager argues that too little is done to prevent soil erosion and that rivers are often blocked with remnants of forestry. Thus, operational managers consider that actors of other domains (e.g. forestry, agriculture and local authorities) impede rather than support their flood risk management efforts.

Water managers are much more positive about the collaboration between actors who are responsible for emergency management. What contributes to this collaboration is that these actors (including water managers, emergency situations managers and public authorities) jointly prepare emergency plans, which are updated every four years. Furthermore, the Ministry of Environment organizes exercises in basins on a yearly basis. Depending on the occurrence of floods and specific needs, the ministry organizes additional exercises with responsible actors and citizens (some branches have more than one exercise per year). The initiative for these exercises is usually with the ministry but sometimes also with specific branches of Romanian Waters. 
The questionnaire results show that the following actors are actively involved in flood risk planning: the inspectorate for emergency situations, local and county councils, owners of hydropower dams and the administration of land reclamation. Less involved are river basin committees. These committees were established to support stakeholder involvement in water management (Law No. 30/2004). They consist of representatives (fifteen in total) of public authorities, water users and non-governmental organizations (NGOs). They have an advisory role in the adoption of river basin plans (required by the EU Water Framework Directive). The national strategy proposes to give them also a role in flood risk management (within the context of the EU FD) (GoR, 2010). However, this would not improve the functioning of these committees, which is a problem according to Romanian Waters and an NGO in the Prut basin. Among the problems are that many members have a political status and therefore are regularly replaced. Also, if there are meetings, there is very limited interaction. Meetings are rather about providing information than real consultation. In recent years, only the technical secretariat of the committee met on a regular basis; advice of other actors was obtained in writing. The questionnaire results show that in many basins important actors, such as navigation authorities, the local population and landowners, are not involved in flood risk planning. Collaboration with NGOs, forest administrations and environmental agencies is limited to information exchange. Information is also provided to the general public via the internet and through other information materials. Every branch of Romanian Waters has a website on which river basin plans are published. Further, in 2008 and 2009, Romanian Waters started to really consult - for the first time - water users, NGOs and other interested parties in public meetings. These meetings were organized for the implementation of the EU Water Framework Directive. These meetings were not very successful. An operational manager of Romanian Waters explained that the number of attendants was low and few questions were posed. An NGO representative explained that there is little interaction during these public meetings. Generally, real involvement and participation in environmental decision-making is still very rare according to environmental NGOs. In the experience of local authorities, their perceptions are not taken into account making them less interested to participate (Vinke-de Kruijf, 2011b).

\section{Problem perceptions and goal ambitions}

Like in many other countries, ideas about flood risk management have been changing in Romania. National strategies stress that there is a need to move away from a defensive and passive 'fighting floods' approach and to focus instead on the proactive management of floods. Central is no longer the construction of dikes and dams but the identification, monitoring and assessment of risks. Moreover, the new strategies are based on the principles of sustainable development (implying that social, economic and ecologic objectives are included) and 'best practices' such as, creating more space for the river and living with floods. Another important ambition in the new strategies is to better protect the 
population from floods (GoR, 2005b, 2010). Currently, inhabitants are in some areas only protected against floods with a return period of twenty years. The medium/long term strategy aims to raise this protection to a return period varying between one hundred and ten thousand years, depending on the number of inhabitants and technical, socio-economic and environmental factors. The potential impacts of climate change are recognized in the national strategy and plans but not fully elaborated yet (GoR, 2010).

Practical experiences show that the new perspective on floods is not yet widely accepted. For example, following the flood events along the Danube in 2006, the Ministry of Environment initiated a study concerning the 'Ecological and Economic Restoration of the Danube floodplains in the Romanian sector', the so-called REELD study (GoR, 2006). In the study, three potential scenarios for the future use of floodplains were explored: (1) agriculture; (2) combination of agriculture and water storage; and (3) ecological restoration of wetlands. The study results were contested and led to strong discussions between actors who participated in public meetings. Particularly actors with a background in engineering and agriculture wanted to maintain the existing flood defence system whereas other actors were in favour of the overall ecological restoration of floodplains (MEF, 2008). The results of the study were never implemented but taken into account in a pilot project focusing on the creation of more space for the river. Also in this project, actors initially persisted in the assumed contradiction between ecology and economy. In an interactive process that was led by external experts, various actors nevertheless reach an agreement about directions for solutions that integrated their diverse problem perspectives. However, the results of this project were also not further developed by national authorities (Vinke-de Kruijf, 2011b). Another project in which various water management issues were integrated shows that synergy is difficult to achieve at a larger scale since funds are not allocated to integrated but to specific objectives (Vinke-de Kruijf, 2012). At the local level, there are better opportunities to implement measures that support the achievement of multiple goals. Local authorities can apply, for example, for environmental funds to create bird reserves or parks and thereby achieve recreation, nature and water storage goals.

\section{Strategies and instruments}

Until recently, the construction of dikes and dams was the most important strategy for flood protection in Romania. The new national plan and strategies provide a framework for a more comprehensive approach that includes prevention, protection and preparedness measures. The questionnaire results show that, until now, basins have been relatively successful in technical flood protection, prevention and preparedness activities. Currently, priority is given to the development of risk maps and hazard maps, which are required by the EU FD and prepared in collaboration between county councils and Romanian Waters. Prevention measures, which are meant to increase the retention capacity of the river or the river basin (e.g. through regulation of land use or the creation of more space for the river), are seen as useful but difficult to implement. As explained above, one of the underlying 
problems is that these measures are still highly controversial. According to a national policy maker, the Ministry really encourages (at some locations successfully) spatial measures that help to realize a 'Green Corridor'. However, such measures are only achievable when land is uninhabited and not fit for agricultural purposes. In recent years, the government made a few attempts to relocate inhabitants from flood-prone areas to higher grounds. However, these attempts were very unsuccessful. In one case, only $10 \%$ of the newly constructed houses are in use. The actual practice is that the highest priority is still given to the implementation of technical flood defence measures. The international flood action plan for the Prut and Siret, two important tributaries of the Danube, shows that the government plans to invest mostly in structural measures, such as to strengthen or heighten river banks or dams and to regulate river beds. The plan also mentions the ecological restoration of former channels or floodplains, which was successfully done in one area with external support. However, no other concrete projects are foreseen (Flood Protection Expert Group, 2009).

While spatial flood prevention measures are hardly implemented yet, other non-structural measures are increasingly used. In the last years, considerable efforts were made to modernize information systems with financial support of the EU and the United States. In 2003, a meteorological monitoring and forecasting system (SIMIN) was implemented. Furthermore, an automated hydrological monitoring and decision support system (DESWAT) and an integrated monitoring system (WATMAN) were implemented (Adler et al., 2006). Whether these systems are also functioning well is yet unclear. At the end of 2009, experts did not make use of such models but made prognoses by hand using mostly regional weather forecasts. Until recently, some of the automated monitoring systems were also not functioning well due to poor installation or vandalism. For example, experiences with the pilot implementation of an innovative flood information and warning system show that Romania does not yet have the right basis to really benefit from such a system (Vinkede Kruijf, 2011a). Another instrument that was introduced in 2008 was mandatory insurance of houses against floods and other national disasters. Until 2009, the number of insured households was much lower than in other European countries but this has improved since then (Apostol, 2009).

\section{Responsibilities and resources}

The majority of the flood protection dikes along the main rivers $(7100 \mathrm{~km})$ are owned by Romanian Waters. This administration is responsible for the overall management of all water systems, including flood protection. Another important owner of flood protection infrastructure is the Authority for Irrigation and Drainage (under the Ministry of Agriculture), which owns dikes along the Danube $(1200 \mathrm{~km})$ and interior rivers $(1100 \mathrm{~km})$. The national government started a process to transfer the ownership of these dikes to Romanian Waters (Vinke-de Kruijf et al., 2013). Furthermore, there are about 2000 dams with a role in flood protection. Nearly all large dams with a highly important role in flood 
protection (about 200) are owned by Romanian Waters or by the hydropower company (under the Ministry of Economy). The smaller dams are owned by other parties: the land improvement authority, local authorities, fishery associations and private agents or individuals (Abdulamit \& Tanasescu, 2009). Since 2005, owners are obliged to maintain the safety level of dikes and dams with a role in flood protection. However, particularly the small owners lack the financial resources for this. The capacity of the Irrigation and Drainage Authority was also questioned by an independent expert, who argued that they lack equipment and personnel for dike inspections and that works are executed by inexperienced external companies.

The management of floods is further affected by the ownership and management of land. Following the fall of the communist regime, large areas of agricultural land and forests (often including small water courses and drainage systems with a role in flood protection) were transferred from the state to its former owners. This led to highly fragmented ownership of land by actors with limited knowledge looking for quick economic wins. The resulting deforestation and wrong ploughing practices cause major erosion problems. Through the rural development programme land owners can access EU funds to implement measures to prevent further deforestation and degradation and erosion of soils and also to develop or improve infrastructure (GoR, 2009; Vinke-de Kruijf, et al., 2013).

The management of floodplains or flood-prone areas is another problem. Local authorities are obliged to seek advice from Romanian Waters when arranging an environmental permit for a new building. However, in the last two decades many new buildings were constructed without approval of Romanian Waters. Another important cause behind the construction of buildings in unsafe areas is the lack of adequate information about risks. The questionnaire results show that, until recently, adequate risk maps were lacking in all river basins. Most branches use geographic maps that were made thirty or even forty years ago. No branch has information about the extent or impact of past floods or about the potential consequences of floods with a low, medium or high probability. Many basins further lack sufficient measurement stations and hydrological and hydraulic information. Water authorities, in collaboration with other actors, are currently making huge efforts to transform existing maps into digital format, and to collect additional data for the development of (digital) risk maps.

According to operational managers, most of the legal and technical conditions for flood risk management are in order. The legal framework provides clear guidance on the management of flood risks and the division of roles and responsibilities. They further argue that Romanian Waters has sufficient technical expertise to manage flood risks and to implement the new strategies. The quality of the risk maps, which are under development, is doubted by an independent expert who argues that the surveys that were conducted to collect data are of poor quality. According to operational managers, one of their problems is that they have insufficient financial resources to implement their plans and to maintain infrastructure. 
The financial resources available and required vary across branches. All branches have to apply the same tariff for the water they are selling to users. However, the amount of water that can be sold as well as the amount of infrastructure varies across basins. Hence, some basins are more dependent on national resources than others. The development phase of the national plan was paid for by national authorities. The costs of the implementation phase are covered by responsible actors, which are Romanian Waters, local authorities and water users, as well as the Ministry of Environment and external financing sources (GoR, 2005a). Among these external resources are European funds that are allocated to natural risk prevention in the Sectoral Operational Programme for Environment.

\subsection{Extent and coherence as indicators of supportive governance}

Flood risk governance is, like many other domains in Romania, in transition. Over the past decades, a growing number of levels, actors, perspectives, instruments and resources have become relevant for flood risk management. One of the reasons behind this increase is the fragmentation of property rights since the fall of the communist regime. Many of the water courses, land and infrastructure, which used to be state-owned, are now owned by various public or private owners. This fragmentation implies that water managers increasingly need to collaborate with other actors for the realization of their objectives. Another reason behind this increase is the growing role and influence of international and supranational organizations. Countries in the Danube basin started to coordinate their actions and to develop and implement joint policies and projects. Moreover, the requirements of the EU directives on water and floods on public participation and risk assessment force responsible authorities to enlarge the scope of their flood risk management practices. Although river basins have long been the main unit for water management in Romania, water authorities only recently started to develop management plans at the sub-basin level and to coordinate these plans at the Danube basin level.

The extent of the governance structure has increased in response to the mentioned developments and the occurrence of floods. The government developed new strategies, which recognize that flood risk management involves many different aspects. In line with international best practices, they promote the proactive management of risks and the involvement of actors at various levels. The strategies also state that flood risk management should consider economic, ecologic and social objectives and rely on comprehensive risk assessments. However, further implementation of these strategies and related plans are needed to actually enlarge the extent of the governance structure. For example, adequate information needs to become available so that water authorities can really start to manage flood risks. Furthermore, legislative changes are needed to also implement proposed measures, such as the creation of local flood agencies and the extension of the role of river basin committees. While such legislative changes support the development of a more complete governance structure, change is also needed in practice. The examples of dam ownership and public participation show that regulation is necessary but insufficient when 
actors lack the motivation or resources to act accordingly. In fact, there are still huge discrepancies between policy and practice. For example, while the new strategies promote non-structural measures, most of the planned investments are technical defence measures. Important to notice here is that the proposed changes are largely externally invented or induced. However, real change requires not only the adjustment of formal structures of rules, rights procedures and principles (institutional hardware) but also changes in prevailing discourses (institutional software). Such discourses are difficult to replace or exchange and explain why many of the institutional changes in Eastern Europe did not have the intended effects (Dryzek, 1996). The controversy surrounding the pilot and study on spatial flood protection measures support this argument. What plays a role as well is that Romania is simply urgently looking for ways to improve the safety of the population. Therefore, authorities focus on technical defence measures, which provide quick fixes, but ignore the potential impacts of climate change. A more sustainable approach would be actively involve stakeholders, to adopt adaptive management practices and floodplain restoration measures that are capable of dealing with socio-economic and climatic uncertainties (Pahl-Wostl, 2006). Generally speaking, the growing extent of the governance structure is recognized in policies but not in practice.

The inclusion of relevant aspects into flood risk governance (high extent) only improves the supportiveness of the overall governance structure when there are synergies and interactions between these aspects (high coherence). With the growing fragmentation of resources, the need to collaborate has increased. While actors are not used to collaborate and often have little trust in each other, progress was made over the past few years. For example, various ministries were involved in the drafting of the new strategies, projects were implemented in collaboration with other actors in the Danube basin and actors with a role in emergency situations management are interacting on a regular basis. Furthermore, authorities started to provide and exchange information and to organize public participation. The increase of participatory and collaborative arrangements potentially contributes to the creation of a more coherent governance structure. When actors are not used to interact with each other, their willingness to engage in collaborative activities involving risks will be rather low. Repeated interactions provide actors with additional information about each other. When these interactions are positive, they become more willing to trust each other. Negative relational experiences have the opposite effect (Rousseau, et al., 1998). For example, the participatory development of river basin plans can strengthen or reduce coherence. They can support collaboration and the development of trust, but when resources are insufficient and some areas are given priority above other areas, such processes may decrease the willingness of local actors to trust and collaborate with water authorities. Although collaboration without trust is not unthinkable since financial incentives or institutional mechanisms can replace trust (Raymond, 2006), cooperative agreements are unlikely to emerge when conflict and distrust prevail (Pretty, 2003). Trust is an important ingredient of coherent governance since a certain degree of 
flexibility is always needed. Governance structures should neither be too weak nor too prescriptive, but allow for adaptive behaviour by empowering actors, accepting uncertainty and leaving options open for pooling resources (De Boer \& Bressers, 2011). In the case of Romania, this balance has not yet been achieved and many actors are not yet ready to take collaborative initiatives. Further development of the legal framework can support this, for example, in the case of bilateral agreements or the role of river basin committees. However, what is more important is that actors also start to look for more integration and synergy across policy domains. Currently, responsible actors are particularly looking for ways to bring their own sector in line with EU standards. As a result, for example, actors in the water services sector are preparing their own master plan and so do actors in the water management sector. In this sense, EU environmental policies indeed seem to enhance policy fragmentation rather than integration (Tews, 2009). This again leads us to the external nature of recent policy changes. A transition country like Romania is not necessarily ready for innovations that are internationally seen as the way forward. Policies that work in one place do not necessarily have the same impact in another place. Moreover, a change of policies does not solve problems of implementation (Ingram, 2008). The presented governance assessment can help to solve or prevent such problems by shedding light on the structures in place and their deficiencies. In the case of Romania, the assessment shows that additional efforts are needed to actually include various aspects and to create coherence across various aspects of flood risk governance.

\subsection{Conclusions}

The central question of this chapter is: To what degree do the extent and coherence of Romania's governance structure support the management of flood risks? Using an existing model of governance, we understand supportive governance as a structure that includes and connects all relevant aspects of the five governance dimensions (levels, actors, perceptions, strategies and resources). Taking the EU FD as a starting-point, we made this model operational for flood risk governance. We used the model to assess flood risk governance in the transition country Romania and identified a number of threats that inhibit adequate policy implementation. Many policy changes are currently underway that aim to increase the extent of the governance structure. Such an increase is indispensable given the growing fragmentation of property rights and international policy developments. The need to include more aspects is clearly recognized in the new strategies for flood risk management, but often not yet applied or failing in practice. Among the underlying problems are the poor functioning of participatory arrangements, the lack of resources (particularly information and financial resources) and the controversy surrounding spatial measures. Authorities continue to focus on technical flood defence measures to quickly improve safety instead of implementing measures that take other problems and climate change into account. With the growing number of aspects to be included, the need for coherence has increased as well. In recent years, various measures were implemented that promote and support interactions 
across actors, yet additional efforts are needed to create connections among various aspects. Instead of looking for synergy, actors are particularly busy meeting their own objectives. Changing policies according to international best practices does not solve such problems when discourses and relations do not change as well. An assessment of extent and coherence is beneficial since this helps to identify concrete deficiencies in the governance structure. Such an assessment is no pathway for easy solutions but helps to understand what solutions are likely to work in a country. 


\title{
Chapter 3
}

\section{Case study A: Evaluation of a 'Room for the River' project}

This chapter introduces the framework that was developed for assessing the effectiveness of the case studies. In this chapter, we apply the framework to one of the case studies. The same framework is also used in Chapter 7 to compare the results of all three case studies. The contents of this chapter are based on: Vinke-de Kruijf, J., Augustijn, D. C. M., \& Bressers, J. T. A. (2012). Evaluation of policy transfer interventions: lessons from a DutchRomanian planning project. Journal of Environmental Policy and Planning, 14(2), 139160.

\begin{abstract}
The transfer of environmental knowledge from one country to another is a widespread practice. This chapter presents an evaluation framework to assess the effectiveness of projects that involve such a transfer. It focuses on project-based interventions that are supported by actors of the transferring country. The developed framework is based on the recognition that policy transfer interventions are multi-actor processes and are therefore best understood as processes of social interaction. Whether such processes contribute to goal achievement depends on the engagement of users in the process. We further argue that the realization of ultimate outcomes can be estimated or explained on the basis of changes in the characteristics of actors involved. The framework is applied to a Dutch-funded project on flood risk planning in Romania. The ultimate goal of this intervention was to contribute to the solving of water-related problems in Romania and to generate follow-up projects for the Dutch water sector. Central in the project was the active involvement of regional stakeholders in the development of regional spatial plans. Application of the framework shows that the case study is unlikely to contribute to the realization of the desired ultimate outcomes. Process explanations include poor institutional embedding, limited diffusion of project results and a lack of adaptive management. The active involvement of local and regional stakeholders created a shared motivation and knowledge base. However, the project got stuck in a lack of resources as actors with decision-making power were not involved and ignored the project results.
\end{abstract}

\subsection{Introduction}

It is widely acknowledged that the number of policy transfer activities are on the increase. Reasons for this increase include globalization, the rapid growth of communication means 
and the rise of international organizations (Dolowitz \& Marsh, 2000). Other possible causes include the growing importance of transnational (non-state) organizations and policy transfer networks, Europeanization and the changing role of governments (Evans, 2009b). Policy transfers are not only widespread, they can also take many different forms and may include voluntary as well as coercive elements. Voluntary transfers or lesson-drawing are the result of a deliberate search for fresh knowledge in other countries (Rose, 1993). Coercive transfers involve situations in which one government or supranational institution pushes or forces another government to adopt a policy. In addition, circumstances often push a country to adopt policies from another country, for example, if political actors perceive that their country is lagging behind (Dolowitz \& Marsh, 1996). This applied to many Eastern European countries, who tried to catch up - politically and economically with democratic nations with free market economies (Rose, 1993). Some governments are also proactive in spreading or exporting their policies. Such transfers are not coercive but often involve elements of persuasion of learning. They may also occur through nongovernmental actors, such as consultancy companies (Stone, 1999). The last form of policy transfer, or rather interventions that involve such transfers, are central in this chapter. More specifically, it focuses on interventions that are financially and substantively supported by actors of the transferring country for the purpose of exporting policy-relevant knowledge.

A policy transfer can be defined as a process in which knowledge about policies or institutions in one setting is used for the development of policies or institutions in another setting (De Jong \& Mamadouh, 2002; Dolowitz \& Marsh, 1996). Policy transfers may concern knowledge about a wide variety of objects, including policies, institutions, ideas or attitudes. Lessons can further be drawn both from another time (i.e. the past) or another place (i.e. the same or another county or the sub-national level) (Dolowitz \& Marsh, 2000). In this chapter, we concentrate on processes that concern the transfer of knowledge about concepts and methods from one country to another. Most early studies about such transfers focused on the transfer between two nations. However, reality appears to be much more 'networked' which implies that transfers tend to involve a wide variety of actors (De Jong \& Edelenbos, 2007) from within the government (e.g. elected officials, civil servants or politicians) and outside the government (e.g. interest groups or experts outside the government) (Dolowitz \& Marsh, 1996). In other words, policy transfers are, like public governance, shaped through the interaction between a wide range of public and private actors (Bressers \& Kuks, 2003). Therefore policy transfers are conceptualized in this chapter as processes that are shaped by the dynamic interaction between mutually dependent actors (Bressers, 2009; Koppenjan \& Klijn, 2004).

Central question in this chapter is how to evaluate the effectiveness of interventions that involve the transfer of environmental policy concepts, methods or technologies from one country to another. The reason for referring to these processes as interventions is to emphasize that they concern "an action taken within a social context for the purpose of producing some intended result" (Babbie, 1992 p. 347). Effectiveness is defined as the 
extent to which an intervention contributed to the achievement of intended or desired outcomes. To assess this effectiveness, we developed an evaluation framework which is inspired by literature on policy implementation, evaluation and adjacent fields. The reason for not focusing on policy transfer literature is that we share the opinion that policy transfers are often difficult to disentangle from and very similar to other policy processes. We further found that the selected sources focus more directly on our topics of interest (James \& Lodge, 2003). The developed framework is also applied to assess the effectiveness of a case study, which is a Dutch-funded flood risk planning project in Romania.

The outline of this contribution is as follows. Section 2 introduces how we conceptualize policy transfer interventions and presents our evaluation framework. Section 3 presents the case study methodology. Section 4 describes the process and outcomes of the case study project. In section 5, the evaluation framework is applied to the case study. The last section presents our main conclusions about the framework including its application to the case study and its general applicability.

\subsection{Evaluation of policy transfer interventions as processes of social interaction}

\section{Characteristics of project-based policy transfer interventions}

Policy transfer interventions can be understood as "communicative interventions that are meant, among others, to develop and/or induce innovations which supposedly help to resolve (usually multi-actor) problematic situations" (Leeuwis \& Van den Ban, 2004 p. 27). This definition highlights that transfers often involve an innovation, i.e. the creation of "novel patterns of coordination and adjustment between people, technical devices and natural phenomena" (ibid p. 28). In this sense, they are often pilot projects, i.e. projects that involve the application of new approaches to learn about the interaction between the innovation and its context. These lessons learnt may be used to improve the innovation or to adjust policies or management practices (Vreugdenhil et al., 2010).

Another characteristic of policy transfer interventions is that they are usually legitimized by a problematic situation, i.e. a gap between a desired situation and an observed situation. In an environmental planning context, problems often represent so-called wicked or unstructured problems. This means that there is uncertainty or disagreement about the existing knowledge base and about the yardsticks used to define the problem (Hisschemöller \& Hoppe, 1995; Rittel \& Webber, 1973). The unstructured nature of many environmental problems relates, at least partly, to their multi-actor or networked context. Such network of mutually dependent actors emerges if authority, knowledge and means are distributed across various actors (Koppenjan \& Klijn, 2004). This is often the case in environmental problems and adds to their complexity. In a single-actor setting (i.e. there is 
one actor or one group of actors that can make an authoritative decision on a problem) complexity mostly arises from system complexity and uncertainties about the effects of potential solutions. Problems that arise in a multi-actor setting are characterized by additional complexity that results from the involvement of multiple actors with diverging interests and perceptions of reality (Van de Riet, 2003).

A distinctive feature of policy transfer interventions is their actor constellation. Regular policy processes are usually initiated by a leading governmental agency (who decides also upon allocation of resources) who delegates actual management to a process manager (Beierle \& Konisky, 2000; Bots et al., 2011). Supported policy transfers tend to be sponsored and managed by an agency and experts of a transferring country who cooperate with a lead government agency in the receiving or benefiting country. Instead of providing resources, the lead agency now becomes the main beneficiary. The reason for collaboration is that the receiving country is interested in solving a problematic situation but lacks the capacity and/or financial resources for this and is interested to learn about innovative solutions. Transferring actors want to export their expertise but tend to lack the authority and context-specific knowledge needed for the intervention. This implies that transferring and benefiting actors are mutually dependent on each other's resources.

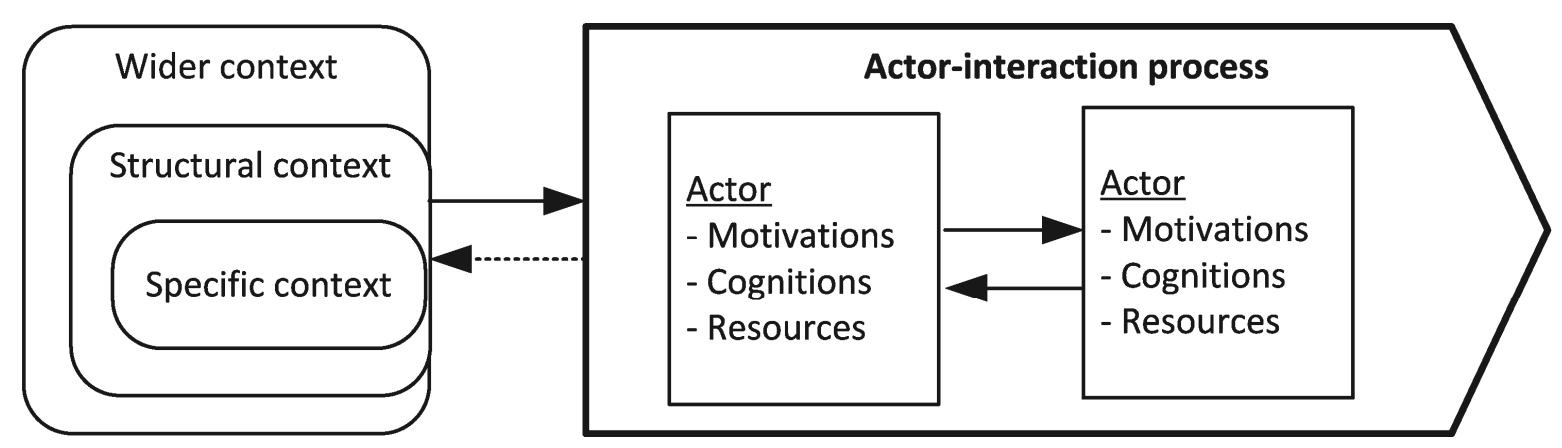

Figure 3.1 - Policy transfer interventions as social interaction processes (adapted after Bressers, 2004, 2009)

The above shows that policy transfer interventions usually have a different objective and actor constellation than regular policy processes. But they are also similar to regular policy processes as they involve a multi-actor problematic situation. They can therefore be understood and explained using the Contextual Interaction Theory (Bressers, 2004, 2009). This theory is rooted in policy implementation and instrumentation theories. It was complemented later with insights into actor networks, learning and governance. The basic assumption behind this actor-centred theory is that policy processes are basically driven by the characteristics of actors involved. These characteristics are their motivations (what drives their actions), cognitions (information held to be true) and resources (power and capacity to act). Other factors may have an influence on the course and outcomes of the process but only via changes in the characteristics of the actors involved (Figure 3.1) (Bressers, 2004, 2009; De Boer \& Bressers, 2011). The theory has been used for various purposes, such as to understand institutional changes or boundary judgements. In this 
chapter, the theory is used to link the interactive process to the likelihood of realizing desired outcomes, by focusing on changes in actor characteristics (Owens, 2008).

\section{Evaluation of policy transfer interventions}

Evaluations can focus on many criteria and pay attention to various aspects of an intervention. Central in this evaluation is effectiveness, i.e. the realization of desired or intended outcomes. Since any outcome evaluation is incomplete without an assessment of the process (and vice versa) (Scriven, 1991), we pay attention to both outcomes and process. Process refers here to the actor interaction through which inputs are converted into outputs (De Boer \& Bressers, 2011). Outcomes are the outputs or effects of the process and encompass immediate outcomes (proximal or end-of-treatment outcomes) and long-term outcomes (distal or ultimate outcomes) (Rossi, et al., 2004; Scriven, 1991). Our focus on process and outcomes implies that other aspects, such as the intervention need, the design or efficiency, are not explicitly taken into account (Rossi, et al., 2004).

One of the main challenges in evaluation research is to define what distinguishes an effective intervention from a less effective one. In mainstream project evaluations, effectiveness is often measured as the conformance between project plan and final outcomes. This, however, ignores the quality of the process (Faludi \& Altes, 1994). Moreover, it neglects that problems are solved in multi-actor settings, which often lack a central objective or a clear substantive yardstick that can be used for evaluation. Actors involved have their own objectives, which tend to change during the process (Koppenjan \& Klijn, 2004). It is therefore argued that multi-actor processes should rather be evaluated in actor-specific or process-oriented terms, such as, the degree of learning, solving of actorspecific problems, the development of sustainable relations, fairness, actor satisfaction or enrichment of ideas (de Bruijn \& Ten Heuvelhof, 2008; Edelenbos \& Klijn, 2005; Koppenjan \& Klijn, 2004). Besides that such criteria completely ignore the relevance of environmental outcomes, actor-specific criteria are also very difficult to measure. The objectives of an actor do not only change over time, actors are often also not able or willing to make their goals explicit. For example, because their goals are difficult to explain, are considered to be generic (and not worth mentioning), represent meta-level goals or are hidden intentions (Vreugdenhil, et al., 2010).

Given the difficulties associated with the evaluation of project-specific and actor-specific goals, we adopt an idea from strategic planning literature, which is that plans should be evaluated in terms of their actual purpose. In case of planning, the actual purpose is to improve the quality of decision-making. Hence, evaluations should question whether a plan contributes to that purpose (Faludi \& Altes, 1994). The actual purpose of policy transfer interventions (and of multi-actor processes in general) varies from case to case. However, their actual purpose will be closely related to the achievement of certain social and/or environmental outcomes (Koontz \& Thomas, 2006; Mandarano, 2008). The focus of this 
chapter is on interventions that involve the proactive export of Dutch water management knowledge to developing or transition countries. The Dutch government financially supports such transfers in order to contribute to the solving of complex global issues (e.g. climate change adaptation and environmental sustainability), to share knowledge (i.e. support countries with Dutch expertise and learn from other countries' experiences) and to strengthen the international position of the Dutch water sector (Min. V\&W, 2009). The two main purposes of such interventions are thus: (1) solving water-related problems in the benefiting country (or at least contribute to this); and (2) generation of new projects for the Dutch water sector. In other words, interventions that are supported by the Dutch water sector are effective when they contribute to the realization of these ultimate outcomes at the programme level.

The desired intervention outcomes often only become visible on the longer term. However, what ultimate outcomes can be reasonably expected is predictable by assessing immediate outcomes (Rossi, et al., 2004). Inspired by literature on utilization-focused evaluation (Patton, 1978) and on the evaluation of communicative planning (Faludi \& Altes, 1994) and transdisciplinary research projects (Walter, et al., 2007), we assume that the realization of desired outcomes mainly depends on user engagement. Users refer here to actors who are needed for the realization of outcomes because they have a crucial role in the intervention itself (current critical actors) or in follow-up actions (future critical actors) (Vreugdenhil, 2010). Inspired by the Contextual Interaction Theory, we further assume that the interactive process shapes actor characteristics, which form a basis for the realization of ultimate outcomes (Bressers, 2004, 2009). This results in an evaluation model consisting of three components: process, immediate outcomes and ultimate outcomes (Figure 3.2). The conceptual model shows that an intervention process has a direct influence on immediate outcomes which have a direct influence on ultimate outcomes (Rossi, et al., 2004; Walter, et al., 2007). Process and outcomes may develop simultaneously and interact with each other, which is indicated by the feedback loops.

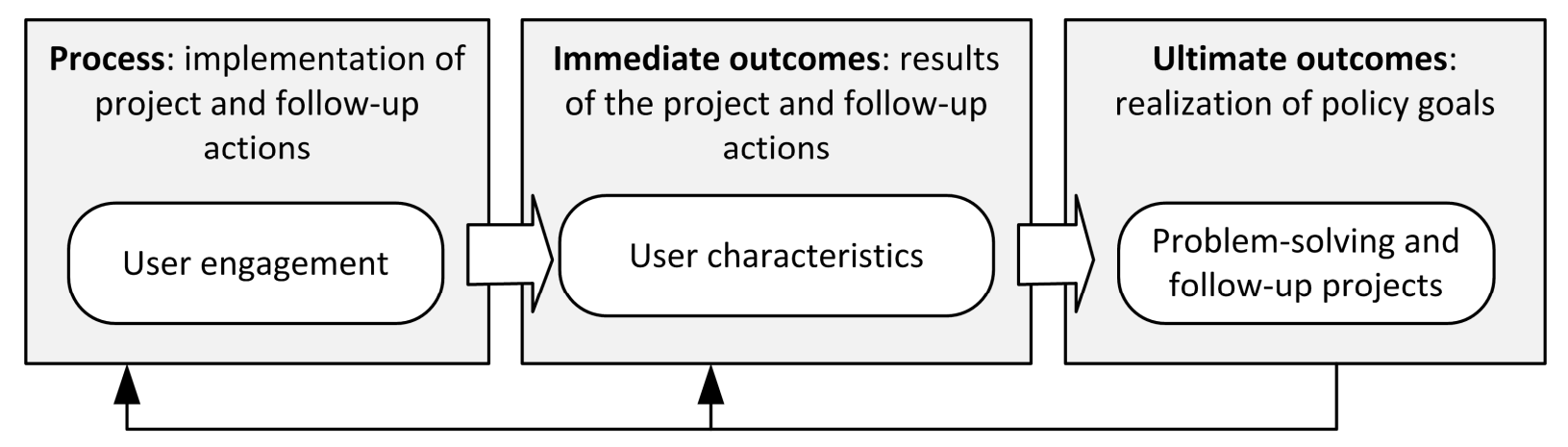

Figure 3.2 - Basic evaluation model: the process results in immediate outcomes and ultimate outcomes.

\section{Criteria for the assessment of the process}

For the assessment of 'user engagement', we developed six process-related criteria (Table 3.1). It is argued that, in order to be effective, water projects should take into account the 
interests of those living or working in the area (local stakeholders) and of local, regional and national institutions (Wesselink, 2007b). Hence, the first criterion is stakeholder involvement. It pays attention to the level of involvement (information, consultation or active involvement) and power sharing (i.e. the influence of stakeholders on decisionmaking) (Krywkow, 2009). The second criterion is institutional embedding. It is based on the recognition that externally sponsored policy transfers easily run the risk of being implemented at a distance from regular policy and decision-making processes. To have a policy impact (i.e. results are incorporated in decision-making or policy making) it is crucial that the institutional embedding of an intervention is well-organized. This means that civil servants are actively involved during the process, that executives play an active role or are committed to the process, and that politicians also identify a role for themselves in the process (Edelenbos et al., 2008).

The third criterion is integration of context-specific knowledge. This criterion acknowledges that the active involvement of relevant actors in the benefiting countries is not only needed to create involvement and ownership but also to gain access to relevant knowledge and networks (Leeuwis \& Van den Ban, 2004). External experts usually have limited access to specific knowledge of local conditions and social patterns. The rather general knowledge of these experts (e.g. theories, models, concepts or techniques, methods and tools) may be very useful and enriching, however, as interventions concern specific situations the creation of a relevant knowledge base usually largely depends on specific knowledge of societal stakeholders (Gummesson, 2000; Leeuwis \& Van den Ban, 2004). To create contextspecific and negotiated knowledge there is usually a need to integrate general knowledge of experts with context-specific knowledge of stakeholders (Eshuis \& Stuiver, 2005; Hommes, et al., 2009b). This has the additional advantage that actors who are involved in shaping a knowledge base are also more likely to accept it (Hommes, et al., 2009b). The fourth criterion is mutual understanding in communication. International projects tend to involve actors with different socio-cultural, organizational and professional backgrounds who tend to have difficulties in understanding each other (Stenmark, 2002). There may be a need to overcome different 'worldviews' or native language barriers through the use of figurative language. Face-to-face interaction is important for the sharing of tacit knowledge (Koskinen, et al., 2003).

The fifth criterion is a proactive diffusion strategy. This criterion recognizes that policy transfers often concern pilots or test cases. This means that they are developed with the intention of using their results to adjust management or policies and to initiate new projects at a comparable or larger scale. Literature shows that the actual impact of pilot projects is often limited due to poor diffusion management. Strategies that can enhance the diffusion of a pilot include the inclusion of diffusion activities in the project plan and their implementation in an early stage of the pilot (Vreugdenhil, et al., 2010). The sixth criterion is a sufficient degree of adaptive management. This criterion acknowledges that interventions are implemented in a changing context that is characterized by uncertainty 
and ambiguity. An adaptive approach recognizes the importance of learning and the need to adapt strategies and goals during the process in response to new information (Pahl-Wostl et al., 2007c). Adaptive management means that interventions are approached as flexible processes in which goals and means are adapted to changing circumstances, new insights and other emergent dynamics (Leeuwis \& Van den Ban, 2004).

\section{Criteria for the assessment of immediate outcomes}

Central in the assessment of immediate outcomes are four criteria that indicate convergence of actor characteristics (Table 3.1). The reason for focusing on these characteristics is that the likelihood of implementation (i.e. realization of ultimate outcomes) can be predicted on the basis of the motivations, cognitions and resources of actors involved (Owens, 2008). Our first criterion is the development of a joint motivating goal and is based on the recognition that realization depends on whether dominant actors (i.e. actors with obstruction or realization power) are motivated. If they are, they may even enforce implementation. If they are not, they may obstruct realization. The second criterion is negotiated knowledge and relates to the information or knowledge base that is required for realization. The term 'negotiated knowledge' is used to indicate that the solving of multiactor problems requires a knowledge base that is relevant, agreed upon and scientifically valid (De Bruijn et al., 2010; Koppenjan \& Klijn, 2004; Van de Riet, 2003). Realization further requires mobilization of necessary resources. This means all resources necessary for follow-up are available and accessible (Bressers, 2004). Relevant resources include human resources (people), information resources (knowledge), financial resources (funds) and institutional resources (power to get things done). The fourth criterion is positive relational experiences and is based on the recognition that future cooperation also depends on the development of trust. Trust is a collective resource that actors can develop when they cooperate with each other over a longer period of time (Bressers, 2009). In relatively new relationships, the willingness to trust is usually limited to specific exchanges and based on reputation or certification. If actors interact with each other over a longer period of time they gain additional information from within their relationship. Positive collaboration experiences make actors more willing to trust, and thus willing to continue their cooperation (Rousseau, et al., 1998). 
Table 3.1 - Criteria for the assessment of the process, immediate outcomes and ultimate outcomes

\begin{tabular}{|c|c|}
\hline \multicolumn{2}{|l|}{ Process criteria } \\
\hline $\begin{array}{l}\text { Stakeholder } \\
\text { involvement }\end{array}$ & $\begin{array}{l}\text { Were actors (depending on their interest in the issue) informed, consulted } \\
\text { or actively involved and able to influence the decision-making process? }\end{array}$ \\
\hline $\begin{array}{l}\text { Institutional } \\
\text { embedding }\end{array}$ & $\begin{array}{l}\text { Were those representing the government (i.e. civil servants, executives or } \\
\text { politicians) actively involved or having a role in the process? }\end{array}$ \\
\hline $\begin{array}{l}\text { Integration of context- } \\
\text { specific knowledge }\end{array}$ & $\begin{array}{l}\text { Was the knowledge of (external) experts combined with context-specific } \\
\text { knowledge of experts and stakeholders of the benefiting country? }\end{array}$ \\
\hline $\begin{array}{l}\text { Mutual understanding } \\
\text { in communication }\end{array}$ & $\begin{array}{l}\text { Did actors develop similar understandings of project scope and content } \\
\text { and make use of communication means that enhance mutual } \\
\text { understanding? }\end{array}$ \\
\hline $\begin{array}{l}\text { Proactive diffusion } \\
\text { strategy }\end{array}$ & $\begin{array}{l}\text { Did the project include an adequate diffusion strategy and was this } \\
\text { strategy put in place in an early stage of the project? }\end{array}$ \\
\hline $\begin{array}{l}\text { Adaptive } \\
\text { management }\end{array}$ & $\begin{array}{l}\text { Was the project adapted, if necessary, to new insights and changing } \\
\text { circumstances and conditions? }\end{array}$ \\
\hline \multicolumn{2}{|c|}{ Immediate outcome criteria } \\
\hline Motivating goal & Did critical actors develop a joint goal that motivates? \\
\hline $\begin{array}{l}\text { Negotiated } \\
\text { knowledge }\end{array}$ & $\begin{array}{l}\text { Did actors develop a knowledge base that was relevant and agreed upon } \\
\text { by the actors involved and by external experts? }\end{array}$ \\
\hline $\begin{array}{l}\text { Mobilization of } \\
\text { necessary resources }\end{array}$ & $\begin{array}{l}\text { Did actors mobilize the (financial and human) capacity to act and the } \\
\text { power to get things done? }\end{array}$ \\
\hline $\begin{array}{l}\text { Positive relational } \\
\text { experiences }\end{array}$ & $\begin{array}{l}\text { Did actors have a positive collaboration experience and are they willing to } \\
\text { continue their collaboration? }\end{array}$ \\
\hline \multicolumn{2}{|c|}{ Ultimate outcome criteria } \\
\hline Problem-solving & $\begin{array}{l}\text { Did the project result in the solving of a water-related problem or are the } \\
\text { project results used as a basis for (future) problem-solving? }\end{array}$ \\
\hline Follow-up & $\begin{array}{l}\text { Did the project result in any follow-up action or a similar project that } \\
\text { creates economic opportunities for the Dutch water sector? }\end{array}$ \\
\hline
\end{tabular}

\section{Criteria for the assessment of ultimate outcomes}

The ultimate test of effectiveness of an intervention is the extent to which it contributes to the realization of desired environmental and/or social outcomes. The desired ultimate outcomes of Dutch-funded projects are basically to contribute to the solving of waterrelated problems and to generate new projects for the Dutch water sector. The criterion of problem-solving is closely related to the realization of environmental outcomes by means of changed environmental conditions. Projects do not necessarily aim at changing the environment but can also be the first step in a longer problem-solving process. Such a process typically starts with the development of a plan following which a decision is taken 
about whether to continue implementation or not. After actors agree on action, changes can be made to the physical environment so that desired changes in environmental conditions are realized (Owens, 2008). The criterion follow-up projects refers to the idea that interventions are sponsored in order to strengthen the economic position of the Dutch water sector. This means that projects are effective when Dutch actors are, on the basis of the supported intervention, invited to contribute to follow-up actions or to a similar project.

\subsection{Case study methodology}

\section{Research strategy and data collection}

The aim of this study is to evaluate the effectiveness of an externally supported policy transfer intervention and also to explain this by analysing the process and its immediate outcomes. Qualitative case study research was chosen as main research strategy. A single case study was purposefully chosen as this allows for an in-depth, holistic and detailed study of the case and its context. As our emphasis was on in-depth understanding, we selected an information-rich case from which we could learn a lot (Patton, 2002). The selected case, the 'Room for the River in Cat's bend, Romania', is a typical example of a project through which a western country exports policies or ideas to a developing or transition country. At the same time, the project is rather unique and innovative because of its extremely integrated and participatory approach. In most externally supported policy transfers, the transfer of a solution or direction for solutions is central rather than the transfer of an innovative governance style. The Dutch experts had considerable experience with the adopted approach but it was certainly very new in the Romanian context. The case therefore provides new insights in the potentials and limitations of externally supported transfers.

Case study data were collected by means of observations and small interviews during the project and by means of semi-structured interviews and document analysis shortly after project completion. The real time collection of data was preferred above the collection of longitudinal data in retrospective as it allowed the researcher to also collect data about short-lived factors and changes. A disadvantage was that the entire picture was not yet known, which made data collection quite intensive as it was difficult to assess what information is important and what not (Van de Ven, 2007, p. 208). Another disadvantage of the selected case was that its social and environmental outcomes only become visible on the longer term. The likelihood of such outcomes can be predicted but the causal relations between ultimate outcomes and the immediate outcomes and the process were not testable in the case. The collection of real time data about policy transfers is normally also rather complicated and costly due to geographic distance and differences in culture and language. We had these problems to a lesser extent as the first author was living in Romania (period 2008-2011) and had reasonable Romanian language skills. Most of the communication was anyway in Dutch or English or translated from or into English as the project involved both 
Dutch and Romanian actors. The principal researcher participated as observant in most project activities (including a field visit, workshops and stakeholder meetings) in the period between February and December 2009. To reduce our Dutch bias in observations, we involved a Romanian student as second observer. We further asked Romanian project team members to undertake short interviews with eight out of twenty of the design workshop participants. The purpose of these interviews was to assess how participants experienced the workshops. In the period between January and October 2010, the principal researcher undertook semi-structured interviews with nine members of the Dutch-Romanian project team. Furthermore, we analysed written material about the project (e.g. work plan, proposal, reports, maps, minutes and project evaluation forms) and its context (e.g. policies, laws, regulations, studies and newspaper articles).

\section{Data analysis and measurement of core variables}

Case study data were structured and analysed using qualitative data analysis software (ATLAS.ti) and complemented with data about flood risk governance in Romania (collected by means of observations, document analysis, interviews and a questionnaire). On the basis of a preliminary literature analysis, we choose to describe the case study from a chronological and an actor-centred perspective. The first perspective was adopted to understand how the project evolved and focused on the project context, course and outcomes (Koppenjan \& Klijn, 2004). The actor-centred perspective was adopted to understand how dynamic interaction between actor characteristics shaped the process and its outcomes and focused on the motivations, cognitions and resources of key actors and developments in the relational domain (Bressers, 2004). The evaluation framework was developed using abductive reasoning in which the interplay between empirical data and theoretical concepts is central (Van Maanen, et al., 2007). The first step in developing the framework was a further examination of the process (i.e. the implementation of various project phases, the involvement of experts and stakeholders and the integration of expertise), the results (i.e. collective results and results in the motivational, cognitive, resources and relational domains), follow-up (i.e. expectations and activities) and achievement of goals (i.e. actor-specific, project-specific and programme). The second step was to develop a framework that could also be used for cross-case comparison. This step was based on the results of this case study, our own experiences with three similar projects, the experiences of practitioners and insights from literature. The research process is, together with a detailed narrative of the case study, presented in a case study report (Vinkede Kruijf, 2011c). Draft versions of the case description were reviewed by several Romanian project team members, which enhanced its validity.

The evaluation framework consists of three components, which are each divided into several measurable criteria (Table 3.1). The assessment of process criteria mainly builds upon the chronological case description. Immediate outcomes were assessed using the 
actor-centred case description. The assessment of ultimate outcomes was based on data about potential and expected follow-up actions.

\subsection{Case study description: Room for the River in Cat's bend, Romania}

\section{Background}

The Netherlands is well-known for its expertise in water management and Dutch experts are involved in numerous water projects around the world. The international transfer of Dutch water management is also actively supported by the Dutch government through bilateral relations and funding programmes. Between the Netherlands and Romania, bilateral cooperation agreements exist since 1995. Within the context of these agreements, more than 150 environmental projects were implemented with Dutch support between 1995 and 2007. Most of these projects were funded with pre-accession funds. After Romania joined the European Union in the beginning of 2007, the Netherlands decided to gradually phase out its bilateral assistance (RNE \& EVD, 2009). Possibilities for external funding still continue to exist, for example, through the Dutch governmental programme 'Partners for Water'. This programme supports innovative projects of the Dutch water sector in a selection of countries. Our case study - the project 'Room for the River in Cat's bend, Romania' - was also supported through this programme.

The basis of the case study was laid by experts of the Dutch Government Service for Land and Water Management (DLG) and the Romanian Ministry of Environment and Forests (MEF) in 2006 and 2007. On request of the Deputy Minister of MEF, the project would focus on the Cat's bend area, which is located along the Danube River (upstream the Danube Delta and downstream the City of Galaţi). The project area includes territories of three counties (administrative divisions) and seven local communities and borders the cities of Galaţi and Braila (Figure 3.3). In the past decades, most of the lakes and wetlands in this area were drained in favour of agriculture. Like in many parts of Romania, floods occur regularly. Especially in the industrial and residential zones in Galaţi City, there is an urgent need to reduce flood risks.

The objective of the project was to develop an integrated regional plan for the Cat's Bend area using the Dutch 'Room for the River' approach and building upon the results of the Romanian 'REELD' study. The 'Room for the River' concept was developed in the Netherlands to anticipate on the potential increase of flood risk as a result of climate change (see the website www.roomfortheriver.nl). It is based on the recognition that only heightening dikes does not provide a sustainable solution for flood risk management on the long term. Measures should also be taken that create more space for the river, for example, through the displacement of dikes, the construction of flood channels and the adjustment of floodplains. These measures should not just focus on safety but also take into account nature, water quality, spatial quality and regional spatial developments (Min. V\&W, 2009). 
In the Netherlands, 'Room for the River' processes are often designed as 'integrated area development processes'. These are regional planning processes that involve various relevant authorities and stakeholders. To support such processes, DLG developed a method called the 'Sketch Match'. This method was also applied in the case study. It includes workshops and plenary sessions in which various actors (e.g. policymakers, managers or local stakeholders) collectively analyse, define and solve a spatial problem. A Sketch Match usually lasts two to three days and consists of several interactive design workshops. During these workshops, landscape architects 'sketch' (i.e. quickly draw) the ideas of participants on maps. The idea is that resulting plans 'match' (i.e. integrate or combine) various user functions, interests and objectives. On the request of MEF, the project also built upon the 'REELD' study. This study on the 'Ecological and Economic Restoration of the Danube floodplains in the Romanian sector' (Governmental Ordinance No. 1208/2006) was finalized mid-2008. It involved a reassessment of existing flood defences, economic activities in the floodplains and the wetland restoration potential. For the Cat's Bend area, it suggested to combine agriculture and water storage in the future.

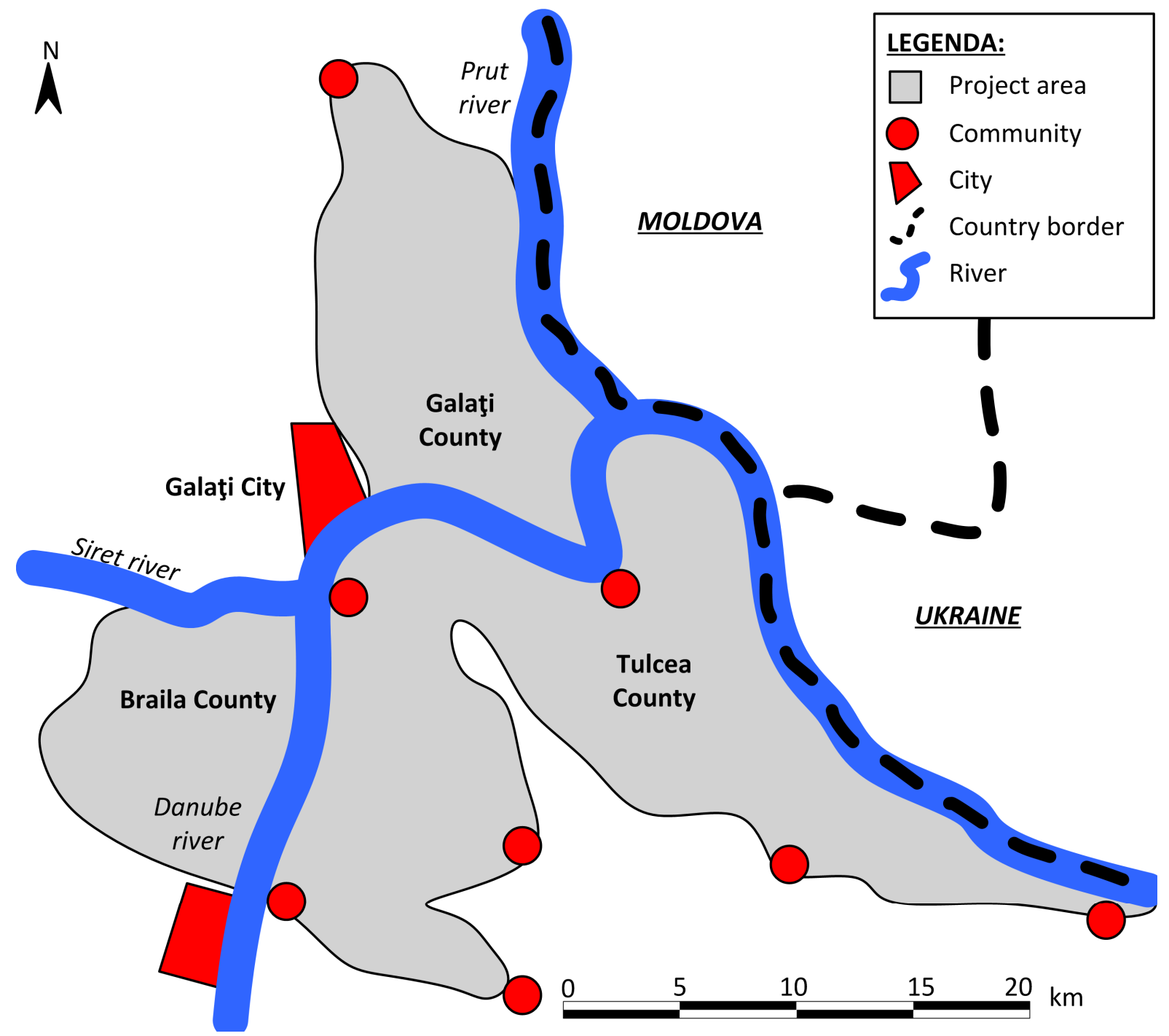

Figure 3.3 - Overview of the project area 'Cat's bend' 


\section{The interactive process}

The project was initiated by a Dutch consortium consisting of a governmental agency (DLG) and a consultancy company (HKV). During the project, experts of these organizations had the lead in managing the project and the participatory process, collecting and analysing geographic and hydraulic data, hydraulic modelling and preparing project reports. They were supported by a Romanian team consisting of a research institute and three environmental non-governmental organizations (NGOs). The research institute was also project manager of the REELD study. Its experts contributed context-specific knowledge and assisted in project management and data collection and analysis. One of the NGOs also contributed context-specific knowledge whereas another NGO facilitated workshops and meetings. The NGOs further contributed knowledge on the participatory process and relevant policy developments (Figure 3.4).
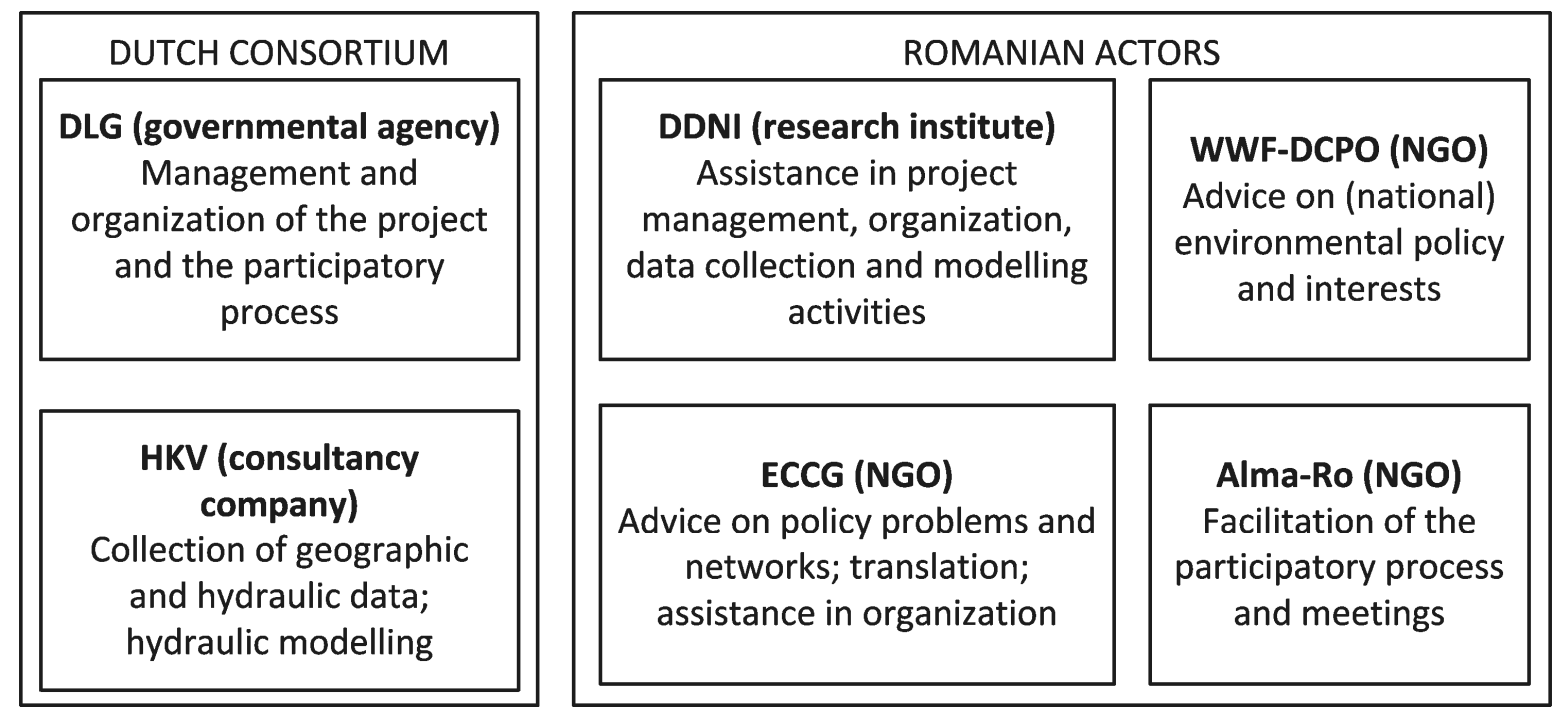

Figure 3.4 - Overview of organizations involved in project implementation and their role

Following visits to Romania in 2006 and 2007, DLG took the lead in forming a project team and developing a project proposal. In September 2008, the project leader visited Romania for the first time, also to become acquainted with three of the Romanian partner organizations. After this visit, preparations for the first mission started and a preliminary stakeholder analysis was carried out. The actual start of the project was in February 2009 when start-up meetings with the project team and with relevant stakeholders were organized in Galaţi City. The stakeholder meeting was attended by a wide variety of organizations, including representatives of MEF, the Prefectures (governor at the county level) and County Councils of Galaţi and Tulcea, six Local Councils, and several other governmental agencies and institutes in the field of water and environment. All invited organizations were represented but high-level representatives were often replaced by one of their subordinates. After these meetings, inhabitants of the area were interviewed about the problems in the area and preparations were made for hydraulic modelling and the Sketch Match. 
In June 2009, the Sketch Match was organized in a small village in the project area. This three-day event consisted of a field visit, three design workshops (three or four groups working parallel) and plenary presentations and feedback sessions. The entire event was attended by fourteen participants and eight participants attended parts of it. The following actors were represented: the County Councils of Galaţi and Tulcea; six Local Councils; agribusiness; local business; a local environmental NGO; regional and national agencies or authorities in the field of water, agriculture, environment and irrigation. In the workshops, the knowledge and ideas of participants were visualized on maps by landscape architects. The result of the parallel groups were discussed in plenary sessions. HKV was also present to calculate the effects of suggested measures on the water level of the Danube (in case of high water). At the last day, the architects integrated ideas into scenarios and presented them to the participants. All participants agreed upon and supported the resulting scenarios.

After the workshop, DLG made a brochure in which the process, its outcomes and recommendations for the future were presented (DLG, 2009). HKV supported the findings with additional calculations and prepared a separate report of the hydraulic study (Groot \& Termes, 2009). In December 2009, evaluation meetings were organized with the project team (in Galaţi), with local and regional stakeholders (also in Galaţi) and with national stakeholders (in the capital city of Bucharest). The purpose of the meetings was to present and evaluate the project and to formulate follow-up actions. The stakeholder meeting was attended by actors similar to the ones that attended the start-up meeting. However, representatives of MEF, the water authorities and the County of Tulcea did not show up. The national meeting was organized by the advisor of MEF but was not attended by any actor with decision-making capacity. Table 3.2 presents an overview of the project phases and related activities.

Table 3.2 - Overview of project phases and related activities (phases are taken from Krywkow, 2009)

\begin{tabular}{ll}
\hline Phase (period) & Activities \\
\hline $\begin{array}{l}\text { Preparation } \\
\text { (2006-Feb. 2009) }\end{array}$ & $\begin{array}{l}\text { Various meetings between DLG and other partners; project team formation; } \\
\text { formulation and acceptance of project proposal; stakeholder analysis. }\end{array}$ \\
$\begin{array}{ll}\text { Inception } \\
\text { (Feb. -May 2009) }\end{array}$ & $\begin{array}{l}\text { Start-up meetings (with the project team and with relevant stakeholders); } \\
\text { interviewing of inhabitants; preparation of hydraulic modelling activities and } \\
\text { design workshops. }\end{array}$ \\
$\begin{array}{l}\text { Core process } \\
\text { (May-July 2009) }\end{array}$ & $\begin{array}{l}\text { Development of spatial plans (including three-day series of design } \\
\text { workshops); calculation of potential effects on the water level using the }\end{array}$ \\
$\begin{array}{l}\text { hydraulic model. } \\
\text { (July-Dec. 2009) }\end{array}$ & $\begin{array}{l}\text { Preparation of a hydraulic report and project brochure; closing meetings } \\
\text { (with the project team, with local/regional stakeholders and with national } \\
\text { stakeholders). }\end{array}$ \\
\hline
\end{tabular}




\section{Development of substantive outcomes}

The projects' substantive objective was to develop three to four regional spatial plans each of them based on a flood protection scenario - in which various user functions were harmonized with each other. In the project proposal - written by DLG with some input of the other partners - flood problems along the Danube River were central. It was argued that canalization and the construction of dikes reduced the space for the river (and thus discharge capacity) and that deforestation and climate change would further increase flood risks. The creation of more space for the river was seen as the 'best' solution. In the inception phase, it appeared that the Romanian project team and stakeholders had another problem perception. In their opinion, socio-economic issues were much more pressing than flood risks. Especially the unjust distribution of land (local inhabitants lack access to resources resulting in poverty) was seen as a major problem. Interviews with inhabitants confirmed the existence of conflicts, for example, between ecology-oriented and economyoriented actors, state landowners and private landowners and local inhabitants and landowners from outside the area. It further appeared that stakeholders were critical about the participatory process. On the basis of previous negative experiences, they doubted whether they could influence the project outcomes and the decision-making process. The interviews further highlighted that there were many conflicts of interests in the area.

Based on the insights of the inception phase, the Dutch team decided to broaden the problem formulation. The central problem was reformulated as a combination of water quantity issues (floods and droughts) and socio-economic issues (land use and poverty). How and whether such issues should be dealt with was contested. Participants also disagreed, for example, upon the profitability of agriculture versus fishery, the necessity and effectiveness of creating more space for the river in the area and the usefulness and applicability of Dutch expertise in general. Instead of focusing on these arguments, the workshops concentrated on: the problems, qualities and potentials of the area in various sectors (workshop 1); the development of existing qualities, irrigation for agriculture and the construction of a by-pass channel (workshop 2); and plans for neighbouring areas and elaboration of the idea for a by-pass channel (workshop 3). In the workshops, participants identified a wide variety of problems, such as the occurrence of landslides, lack of fish, the poor use and performance of the irrigation system. The landscape architects stimulated participants to find solutions for these problems that would also create more space for the river.

After the workshop, the landscape architects came up with three directions for solutions (or design concepts): (1) restoration of an old meander of the Danube (the by-pass channel); (2) improvement of agriculture through creation of irrigation channels; and (3) creating more space for the river by relocating a dike on the North bank of the river (see Figure 3.5). When the extreme water levels of 2006 are used as reference point, these concepts could potentially reduce the water level of the Danube with 6 to $13 \mathrm{~cm}$ or with $24 \mathrm{~cm}$ if all three 
concepts are combined (DLG 2009; Groot \& Termes, 2009). In the evaluation meetings, it appeared that local and regional stakeholders believed that the design concepts could benefit the area. The evaluation meetings were therefore focusing on who was willing and able to take up follow-up activities. According to Romanian experts and regional and local stakeholders, the local and regional level could only realize follow-up if they were supported by national authorities, especially MEF in this case. However, among the highlevel representatives of MEF there was no one who wanted to give this support. Also no organization in the project team was willing or able to mobilize support for further implementation of the project. As a result, no decision was taken about whether or not to further elaborate or implement the design concepts.

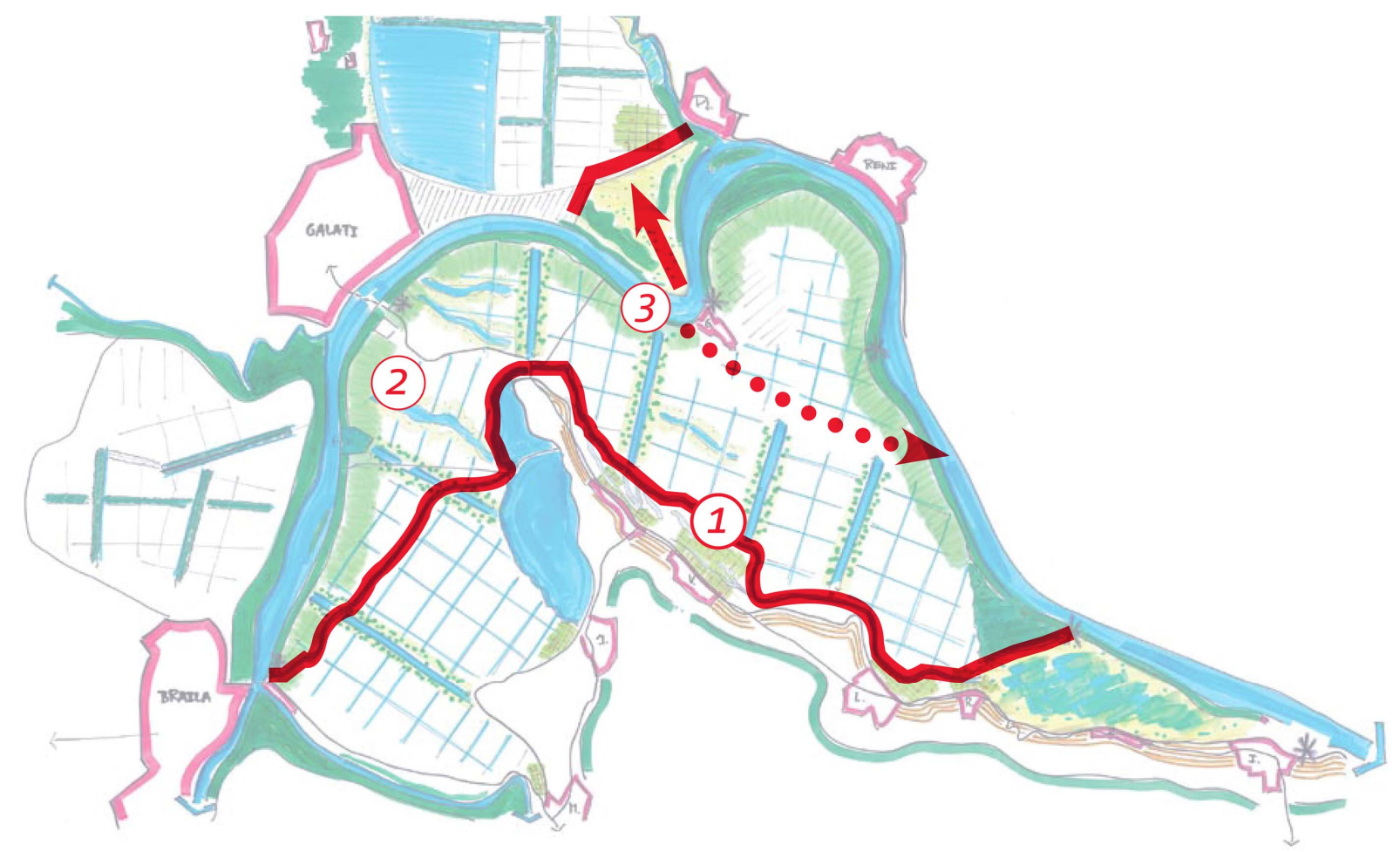

Figure 3.5 - The three design concepts that emerged from the design workshops. The numbers refer to the number of the design concepts in the main text (DLG 2009).

\subsection{Case study results: application of the evaluation framework}

\section{Evaluation of the process}

At first sight, the project scores high on stakeholder involvement. A wide variety of actors was invited to the interactive process including representatives of the government at the county level and the local level, governmental agencies (in various domains) and persons representing the interests of farmers, nature or agribusiness. As the majority of the participants also lived and worked in the area, stakeholder interests were well-represented. Participants were not only informed, but also consulted and actively involved in the development of spatial plans for the area. Although the project scores high on level of 
involvement, stakeholder involvement was medium as it scores low on power sharing. The latter also appears from the fact that decision-makers could easily ignore the project results (Krywkow, 2009). The latter closely relates to the poor institutional embedding of the project. The project was started in close cooperation with a civil servant and the State Secretary of MEF. The first meeting was also attended by a director of MEF and other meetings by a civil servant. With a few exceptions, invited national and regional actors at decision-making positions did not show up. As a result, the project was only wellembedded at the local level as a result of the active participation of various mayors.

As a result of the active involvement of Romanian experts and regional stakeholders, the project successfully integrated context-specific knowledge with the general knowledge of the Dutch experts. The design workshops played an important role in this as it allowed for communication by means of visualizations. According to landscape architects, participants were very open but differences in native language made the process challenging. Not all participants' remarks were translated and informal conversations with participants were not possible. Participants were nevertheless highly satisfied about the manner in which the landscape architects visualized their ideas. Although the mutual understanding in communication with participants was rather good, the communication within the project team was not always effective. Communication lines and responsibilities were sometimes unclear to Romanian experts. Romanian experts were giving delayed or incomplete answers or appeared to have less expertise than expected according to Dutch experts. What played a role in this is that experts had a very diverse background and did not cooperate with each other before. During the project they also had limited opportunities to interact face-to-face with each other. Informal face-to-face interaction is vital for the development and sharing of tacit project knowledge (Koskinen, et al., 2003).

The planned diffusion strategy was to disseminate the project results during presentations (e.g. for national and international decision-makers) and through a project brochure. The proposed diffusion strategy was concentrated at the end of the project and therefore not very proactive. Furthermore, it was poorly implemented: some presentations were aborted and others were not attended by the target audience. As a result, the enthusiasm and perceived success of the pilot was never communicated directly to decision-makers. There were various external and internal developments that asked for adaptive management. The project was quite successful in adapting to new insights. When participants contested the idea to focus on the reduction of flood risks by creating more space for the river, the project team responded by expanding the project scope so that socio-economic issues were also included. The project was less effective in adapting to changing circumstances, such as the replacement of the State Secretary for Water, the dissolution of the Romanian government and the global economic crisis.

The process evaluation shows that the case study was a rather good consensus-building process: it included and really engaged participants of various interests, allowed for 
discussions and incorporated high-quality and agreed upon information. The fact that its results could be ignored by decision-makers, however, shows that the project was not driven by a real task that was shared by all relevant authorities (Innes \& Booher, 1999). The evaluation shows that the case study especially failed to engage users with decision-making power at the regional and the national level. This probably also relates to the projects' participatory approach. Experiences from the Netherlands also show that civil servants, executives and politicians often prefer to watch a participatory processes from a distance, which means that it is rather difficult to engage them (Edelenbos, et al., 2008; Vinke-de Kruijf, et al., 2010). The poor institutional embedding at the national level also relates to the projects' poor adaptation to external developments. These developments also had a negative impact on the implementation of the planned diffusion strategy. The evaluation further highlights that especially the project team had some problems in arriving at a mutual understanding in communication and that stakeholders had no influence as the results of the process were ignored.

\section{Characteristics of end users as immediate outcome criteria}

During the project, actors involved developed a joint motivating goal. This outcome is remarkable given the critical and suspicious attitude of some participants at the beginning. They, for example, had the impression that it was a window dressing process and that the project team used the participants to enforce their 'room for the river' solution. This attitude is understandable given the limited possibilities of local stakeholders to influence decisionmaking and their distrust in local and regional politics (Van Assche, et al., 2011). At the end, participants were very positive about the process. Some were rather surprised that their ideas were taken into account and clearly reflected in the design concepts. Several participants mentioned that stakeholder involvement was clearly the key to the solving of local problems. All participants of the regional meeting valued the design concepts and stated that the government should take on implementation. Romanian experts and stakeholders were also interested to cooperate with Dutch experts again. Especially DLG was interested to participate in similar projects in the future as the adopted approach was clearly of added value in Romania. Although actors involved supported the implementation of a joint motivating goal, none of them was capable and willing to take initiative. Dutch experts stated that the initiative should come from the Romanian side now. Romanian actors argued that they depend on support of the national government. In conclusion, actors involved developed a joint motivating goal but were lacking support of crucial actors at the national level.

The process also resulted in a negotiated knowledge base that was agreed upon by actors involved. At the beginning of the project, perceptions of Dutch and Romanian actors were clearly diverging. Actors had different ideas about the actual problems and desirable solutions. Some participants also doubted whether Dutch knowledge was of value in the Romanian context. During the process, actor perceptions gradually converged. Various 
strategies were adopted that enhance the creation of a common knowledge base including: (a) developing and selecting solutions that can satisfy various interests (i.e. furthering goal intertwinement); (b) moving from substantive variety towards selection; and (c) organizing a process that prevents cognitive fixations, overcomes differences in languages and advances cognitive reflection (Koppenjan \& Klijn, 2004). What also played a role was that participants were closely involved in the development of the knowledge base. This makes them more likely to accept the created knowledge and also creates context-specific knowledge (Hommes, et al., 2009b). Many participants also noted that the involvement of Dutch experts had been of crucial importance and that their approach was of added value in the Romanian context. An aspect that was questioned by some Romanian experts and stakeholders was the validity of the hydraulic calculations. This means that further research is needed to validate the technical knowledge base.

What appeared to be problematic was the mobilization of resources. For the project itself, financial resources and key knowledge was provided by Dutch actors, complemented with context-specific knowledge of Romanian actors. For the realization of follow-up actions, additional resources were needed. DLG did not want to actively mobilize resources as international projects are not part of its core business. Several Romanian organizations expressed their interest to involve Dutch experts in future projects but have limited possibilities to initiate similar projects. Local and regional stakeholders were willing to mobilize resources for the implementation of the design concepts. They, for example, proposed to organize themselves in an inter-community association in order to strengthen their position. However, as most financial resources are distributed via the national government it is widely believed that any form of follow-up crucially depends on support of MEF. There is no indication that MEF will mobilize resources to further elaborate the design concepts or to implement similar projects. The case study is not unique in this. Also in other environmental planning processes, it often happens that actors involved create a relevant knowledge base and are motivated but are not able to realize their objectives as they depend on external resources (Owens, 2008).

Most of the actors involved had positive relational experiences. Romanian experts and stakeholders were all positive about their cooperation with Dutch experts and stated that they would like to cooperate again. Vice versa, this was not always the case. Dutch experts hesitate to cooperate again with one of the Romanian partners. The underlying reason was that their performance did not meet their expectations. New relations and a willingness to continue collaboration was also created among Romanian experts involved. Although Romanian experts had limited contact outside the project activities, several experts stated that, as a result of the project, they would now consider to collaborate with one of the other Romanian organizations in another project. 


\section{Realization of ultimate outcomes}

The case study was not designed to contribute directly to problem-solving but to prepare a plan that could be used as a basis for the reduction of flood risks in the area. Dutch experts hoped that successful application of the innovative approach would also provide a basis for the realization of similar projects along the Danube river. Implementation of this plan would contribute to flood risk reduction in the region. However, for a considerable reduction many more similar projects upstream the Danube river are needed (DLG, 2009). Actors involved did, however, not agree upon any follow-up actions at the end of the project. Actors involved did also not take any initiative to involve Dutch experts in other follow-up projects. Romanian experts mentioned that if the decision to elaborate the plan would be taken, the involvement of Dutch experts was likely given the lack of expertise in this domain in Romania. Also, if they would be involved in a project in which the interactive design method could be applied, they would approach DLG experts. So, in case of any similar project, Dutch experts are likely to be involved. In conclusion, up to our knowledge, the project did not contribute to the realization of ultimate outcomes until now. Even though actors involved developed a motivating goal, negotiated knowledge base and had positive relational experiences, realization is - at least on the short term unlikely - as capable actors were unwilling and willing actors unable to mobilize the resources that are needed for realization.

Even though no concrete outcomes were realized, there have been some follow-up actions. Once the project was finalized, various Romanian experts and DLG continued to promote it among influential actors (e.g. via the Dutch embassy and a Member of Parliament). The critical water levels along the Danube in July 2010 eventually renewed the attention for the project results. It was expected that controlled flooding would be necessary to protect the City of Galaţi from flooding but natural dike breaches at upstream locations prevented this. The Dutch embassy and Dutch experts were asked for more information about the design concepts. The events further resulted in a two-day seminar in which Dutch experts and Romanian authorities (including MEF) discussed possibilities to cooperate on flood risk management issues in Galaţi area. This meeting confirmed that creating more space for the river is still a highly controversial issue in Romania. Given the strong opposition of the powerful agricultural lobby a 'Room for the River' programme is not to be expected on the short-term.

\subsection{Conclusions}

The aim of this chapter was to present and to apply an evaluation framework to assess the effectiveness of projects that involve the transfer of knowledge. We chose to conceptualize policy transfer interventions as multi-actor processes of which the course and outcomes are shaped by actor-interaction processes. The holistic evaluation of such processes requires a framework that pays attention to the process, immediate outcomes and ultimate outcomes. 
By including the process and immediate outcomes, the framework does not only assess effectiveness, it also helps to predict what ultimate outcomes are reasonably to be expected if they are yet unknown (Rossi, et al., 2004) and to explain why an intervention was effective or not. Each component of the framework was conceptualized by several measurable criteria. The developed process and immediate outcomes criteria may not only be useful for evaluation purposes but also assist practitioners in designing and monitoring interventions.

The framework was applied to a case study that involved the transfer of an innovative concept and method, that were developed in the Netherlands, to Romania. The active involvement of stakeholders, the use of visualization (enhancing mutual understanding in communication) and the integration of stakeholder knowledge contributed to the development of a motivating goal, negotiated knowledge base and positive relational experiences. Despite these immediate outcomes, the intervention did not contribute to the realization of desired ultimate outcomes, i.e. problem-solving and follow-up projects. This lack of ultimate outcomes closely relates to the fact that the project failed to engage actors with access to necessary resources for follow-up actions. This especially relates to the projects' institutional embedding and diffusion strategy: both were initially well-organized but poorly implemented. This was also due to external developments to which the project was not well-adapted.

There are several limitations to the general applicability of the framework. Firstly, the framework was designed for evaluating the effectiveness of projects that involve knowledge transfer. This implies that it does not assess the extent to which knowledge was actually transferred or assess the intervention efficiency and need. Secondly, the framework focuses on transfers that involve concrete concepts or methods for the solving of an environmental problem. It is probably less applicable to interventions that involve the transfer of ideas or ideologies or the transfer of methods for the solving of institutional problems. Thirdly, the framework was designed to evaluate interventions that are stimulated by a transferring country. As the introduction showed, policy transfers can take many different forms to which not all criteria will be of relevance. For example, a proactive diffusion strategy is of less relevance if the transfer does not involve a pilot. Also, the desired ultimate outcomes will vary from case to case. However, we expect that the basic framework - i.e. the notion that ultimate policy outcomes depend on user engagement and that this effect is mediated through actor characteristics - applies to any form of policy transfer. Application of the framework is not limited to transfers, it can probably also be used for the evaluation of regular environmental policy processes. Further research is needed to confirm this. 


\section{Chapter 4}

\section{Case study B: The process of knowledge transfer in a FLIWAS implementation project}

This chapter explains how actors and interactions shape the effectiveness of the projects under study. Insights about the transfer and management of knowledge are reflected upon using the experiences of the second case study. This chapter is based on Vinke-de Kruijf, J., Hulscher, S. J. M. H., \& Bressers, J. T. A. (2013). Knowledge transfer in international cooperation projects: experiences from a Dutch-Romanian project. In A, Chavoshian, \& K. Takeuchi (Eds.), Floods from Risk to opportunity (pp. 423-434). IAHS Publication 357. Oxfordshire: IAHS Press. An earlier version of this chapter was presented at the $5^{\text {th }}$ International Conference on Flood Management (ICFM5) in Tokyo, Japan (27-29 September 2011).

\section{ABSTRACT}

The transfer of knowledge to reduce flood risk problems can be beneficial, but is often difficult. This paper shows how knowledge and interaction contribute to the transfer of knowledge in international cooperation projects. It presents a conceptual model of knowledge transfer and applies this to a case study project in which knowledge about the flood information and warning system FLIWAS was transferred from the Netherlands to Romania. The knowledge transfer was only partly effective: Romanian experts intend to further implement FLIWAS, but have not yet started using the project results. The case study confirms that transfer processes involve experts with diverging backgrounds who tend to experience difficulties in understanding each other. Intense forms of interaction enhance the transfer of knowledge, but do not necessarily help to overcome these differences. Previous collaboration experiences and interpersonal aspects are also likely to have a positive impact on the transfer of knowledge. 


\subsection{Introduction}

In Europe, floods are the most common natural disaster. In past decades, the number of reported flood events has been increasing, among others, due to better reporting and land use changes (EEA, 2008). As a growing number of economic and social activities have been moved to flood-prone areas, more land has become exposed and vulnerable to floods (Barredo, 2007). To reduce the adverse consequences of floods, flood forecasting, warning and response systems are currently developed throughout Europe. Contextual differences between these various countries contributed to the development of systems that vary in purpose and sophistication. These variations, and the fact that most countries face similar challenges, suggest that the exchange of information and experiences in this field is beneficial (Parker \& Fordham, 1996). The international transfer of technologies, concepts and methods in the domain of flood risk management is central in this chapter. As such transfers are about the transfer of specialized knowledge or know-how, we refer to them as knowledge transfer (Reddy \& Zhao, 1990). Knowledge transfers are complex processes that are influenced by a wide range of individual and contextual factors (for a literature review, see e.g. Wang \& Noe, 2010). A knowledge transfer can be defined as an interactive process in which various actors share and acquire knowledge for the purpose of applying it. In this chapter, we focus on the question how interaction and knowledge contribute to the effective transfer of knowledge in an international project setting. In this case, effective means that knowledge is not only shared and acquired but also applied in line with intended (casespecific) purposes.

This chapter builds upon a variety of literature on technology/knowledge transfer and knowledge management. These theoretical insights are integrated in a conceptual model and reflected upon in a case study. Case study research was chosen as main research strategy as it allows to investigate a contemporary phenomenon in-depth and within its reallife context (Yin, 2009). As a case study, we selected a Dutch-Romanian project on the pilot implementation of a Flood Information and Warning System (FLIWAS, see the textbox). FLIWAS was developed in a European project with partners from the Netherlands, Germany and Ireland. In 2006, it was implemented by German and Dutch partners in the Rhine River basin. These experiences formed the basis for the pilot implementation of FLIWAS in Romania (De Gooijer, 2010; Langkamp et al., 2006). Case study data were collected by means of direct observation, interviews and document analysis. In the period between July 2009 and April 2010, the first author was involved in the project as an observer. During the whole period, the researcher stayed in close contact with the project team, participated in the main project activities (i.e. meetings, workshops and a final conference) and regularly conducted informal interviews. The researcher tried to avoid any interference with the project that would affect its course and outcomes. The main advantage of observing processes real-time is that change processes can be observed in the field, which maximizes the chance of discovering short-lived factors or changes. However, 
as outcomes are unknown, a researcher may also miss some critical events (Van de Ven, 2007). Therefore, observations were complemented and triangulated with ex post interviews and document analysis. When the project was completed, semi-structured interviews were conducted with the main project partners (four Dutch partners and eight Romanian partners) in the period between June 2010 and March 2011. Analysed documents include project reports and documentation, relevant policies and legislation, newspaper articles and other web-based information. The case study analysis was also inspired by recent analyses of flood risk governance in Romania and several other Dutch-Romanian flood risk management projects. For a detailed narrative of the case study and its context, we refer to the produced case study report (Vinke-de Kruijf, 2011a). The next section introduces our main theoretical concepts and conceptual model. The third section introduces the case study - the pilot implementation of FLIWAS in Romania - and its context. Following this, we briefly discuss the case study findings by reflecting on our main theoretical concepts. Our main conclusions are presented in the last section.

\begin{abstract}
FLIWAS - acronym of Flood Information and Warning System - refers to an internet-based flood information and warning system that collects, structures and presents information needed for the management of emergency situations. The system was developed to provide actors with a role in flood risk management (e.g. professionals or decision-makers) with adequate information. After it has been installed on a server, it can be accessed by any user via a computer that is connected to the internet. The tool does not produce new information but builds upon existing measurement and forecast systems, emergency plans, flood maps and scenarios, and other geographic information (if available). Central are data about the water system (e.g. measured or expected water levels), reference levels and emergency management plans. This data is used to warn responsible actors to take appropriate action when water levels are about to exceed a reference level. Users can also give feedback on whether they executed this action. In this way, FLIWAS can provide all users with up-to-date information about the state of alert and actions that have been taken. The tool can be used to monitor emergency situations and also for exercising and evaluation purposes (see e.g. De Gooijer, 2010).
\end{abstract}

\title{
4.2 Knowledge transfer in an international project setting
}

\section{Towards an interpretation of knowledge and knowledge transfer}

Knowledge transfer can be understood as a process that involves: (1) a source that shares its knowledge (i.e. provides information to others); and (2) a receiver that acquires and applies this knowledge (Wang \& Noe, 2010). In an international setting, the transfer of concepts, methods and technologies seems promising but is hardly ever straightforward. One of the reasons is that the transfer of embedded knowledge is not synonymous to the adoption of a blueprint. Knowledge usually needs to be modified, adapted and developed further so that it fits with the specific circumstances and context in which it is applied. Transfers are 
therefore especially about the integration of new with existing knowledge and also include the creation, assimilation and combination of knowledge (Bresman, et al., 1999; Trott, et al., 1995). What makes transfers also challenging is that they involve a large portion of tacit knowledge or specialized know-how (Lin \& Berg, 2001; Reddy \& Zhao, 1990; Trott, et al., 1995). Tacit knowledge refers to the idea that persons can only express a limited amount of what they know in words or numbers. Knowledge is rooted in a tacit background that is hard to formulize and communicate (Polanyi, 1966). This background is part of the 'lifeworld' in which people live and that they take for granted (Leeuwis \& Van den Ban, 2004). Tacit knowledge is often contrasted with explicit knowledge, this is knowledge that can be articulated in a formal, systemic language and is therefore more easily transferable between individuals (Nonaka, 1994). However, when a source and receiver have diverging backgrounds, they may still be unable to understand shared knowledge. They may, for example, not speak the same language or have other technical capabilities. As explicit knowledge is rooted in a tacit background, they are not two different types of knowledge but rather two intertwined aspects of knowledge (Stenmark, 2002).

Knowledge can be defined as information that is processed and created by individuals (see e.g. Alavi \& Leidner, 2001; Nonaka, 1994; Wang \& Noe, 2010). It is data (i.e. a set of discrete, objective facts) that has been given a meaning (Davenport \& Prusak, 1998). This shows that data and information are closely related to and interwoven with knowledge. They form the basis for the construction of new knowledge and also require knowledge to be understood. The latter implies that what may be data to one person, may be information to another person. In other words, whether knowledge transfers concern the transfer of data, information or knowledge depends on the extent to which the source and receiver share a similar knowledge base (Stenmark, 2002). This also implies that there is not much practical utility in distinguishing between these concepts in analysing knowledge transfers. Transfers are about the provision of information and know-how (Wang \& Noe, 2010). In other words, knowledge in a transfer setting is best understood as a combination of information (knowwhat) and expertise (know-how) (Bresman, et al., 1999; Kogut \& Zander, 1992). Information refers here to the explicit aspects of knowledge, i.e. knowledge that persons are aware of and can capture in language (Leeuwis \& Van den Ban, 2004). Expertise refers to knowledge on a particular subject, including the experiences and the skills to use this knowledge (Wesselink, et al., 2009). Expertise is knowledge that persons develop and accumulate over a period of time, especially by applying knowledge. Expertise is also referred to as procedural knowledge, practical knowledge or the technical elements of knowledge (Davenport \& Prusak, 1998; Kogut \& Zander, 1992; Nonaka, 1994). As expertise is mostly tacit, its transfer requires considerable efforts such as prolonged observation or in-depth discussions. Some knowledge will always remain hidden, for example, because persons are not aware of it (Leeuwis \& Van den Ban, 2004). We are aware that knowledge also has a cognitive component, that it also functions as a frame consisting of beliefs, views and paradigms through which people interpret information 
(Alavi \& Leidner, 2001; Nonaka, 1994). As various persons have diverging interests and interpretations of reality, they will also interpret and judge information differently. This means that knowledge transfers are also about the development of a context-specific and 'negotiated' (i.e. agreed upon and valid) knowledge base (Hommes, et al., 2009b). The cognitive dimension of knowledge has been central in much recent literature on actorinteraction processes (see e.g. Bressers \& Lulofs, 2010). However, the focus of this chapter is on the interaction between and the knowledge of actors involved.

\section{Actors, interaction and knowledge in the knowledge transfer process}

Knowledge transfers in a water management context usually involve a wide variety of actors, which are either involved as a source and/or a receiver of knowledge. How the knowledge transfer process develops depends on the interaction between these actors who have different knowledge backgrounds, types and levels. In an international project, the ultimate purpose of sharing and acquiring knowledge is the application of knowledge for case-specific purposes. The factors that shape the interactive process of knowledge sharing and acquisition and the desired outcomes of such process is schematized in Figure 4.1 and elaborated below.

Actors involved in a knowledge transfer process often represent one of the following social entities: (1) public and stakeholders with general or specific interests; (2) responsible authorities who are in charge of decision-making; and (3) experts that conduct or support the process. Actors can represent one or more entities and this can also change during a project (Krywkow, 2009). Substantive knowledge in such projects may be provided by experts (i.e. specialists with a broader perspective and understanding of the problem situation who are employed to contribute their expertise) and by stakeholders (i.e. persons with context-specific knowledge who are invited also because of their interest) (Collins \& Evans, 2002; Vinke-de Kruijf et al., forthcoming). The importance of stakeholder knowledge depends on the design of a project. A project can be expert-driven and focus on knowledge creation and learning among experts. Expert knowledge can also be supportive if a project concentrates on stakeholder knowledge and learning (Vreugdenhil, et al., 2010). The transfer of knowledge between various actors can be realized using various means of communication. These means include: face-to-face interaction, telephone, written personal, written formal and numerical formal. Direct interaction is the richest medium as it allows for feedback and includes body language. The other means have a decreasing capacity to transfer knowledge in a project context (Koskinen, et al., 2003). The potential to transfer knowledge also depends on whether an interaction setting allows for one-way communication (information provision), exchange of information (consultation) or active cooperation (exchange of perspectives) (Krywkow, 2009). Especially important for the transfer and development of new knowledge is that actors collaborate with each other over a prolonged period of time, for example, in self-organizing teams. This contributes not only to the development of shared meanings and understandings but also to the development of 
mutual trust (Bresman, et al., 1999; Nonaka, 1994). Personal mechanisms are effective means for transferring tacit knowledge. Besides this, it may also be useful to codify knowledge, i.e. to store knowledge in databases and documents so that it becomes accessible for others. Personalization and codification mechanisms can be used in rather informal and decentralized manners and also be organized via collective routines and structures (Boh, 2007). The successful application of such mechanisms tends to be challenging in an international project setting. Projects are usually too short to develop routines and structures that enhance knowledge transfer. Furthermore, they involve actors of different organizations and professional disciplines (Bresnen et al., 2003) that are distant from each other in geographical and cultural terms (Bresnen, et al., 2003). This implies that actors have knowledge backgrounds that differ in terms of knowledge tradition (sociocultural inheritance), profession and organizational belonging. Actors with diverging backgrounds behold diverging tacit assumptions and understandings. Because of these differences, actors can have difficulties to understand and accept each other's knowledge (Stenmark, 2002).

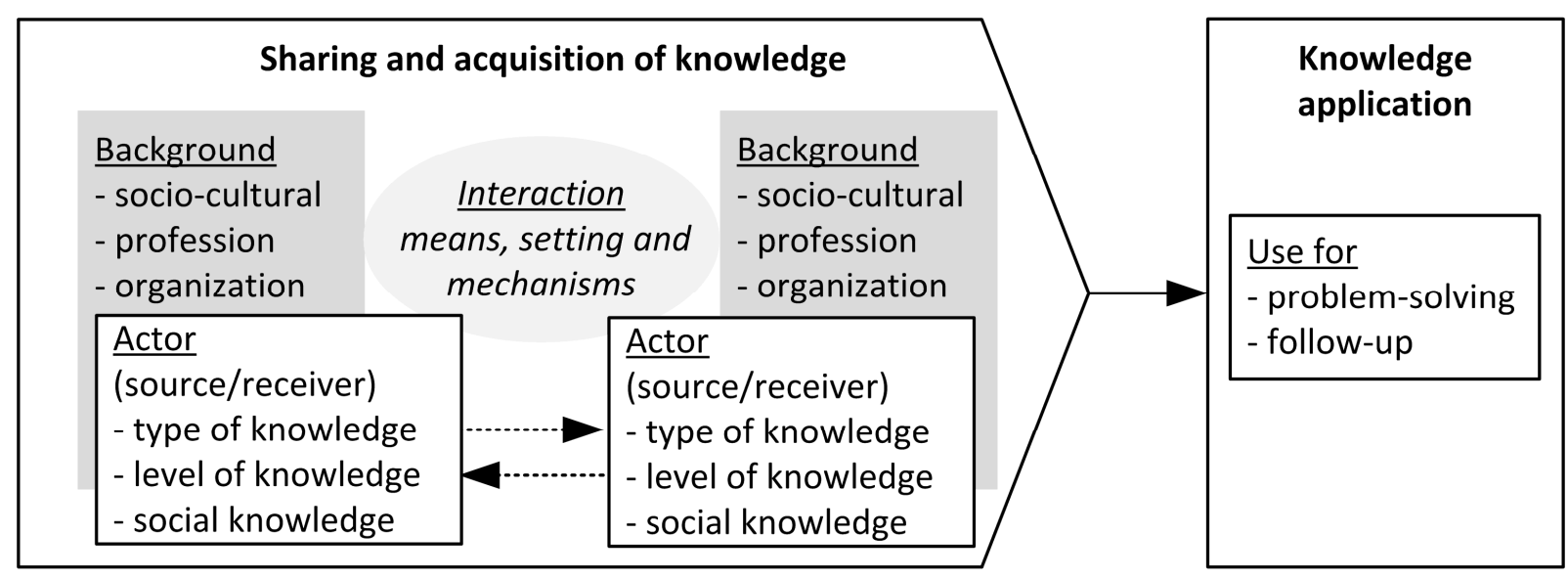

Figure 4.1 - Conceptual model for the analysis of knowledge transfer in an international project setting

Because of their diverging backgrounds, various actors tend to have knowledge that differs both in content and orientation (Hommes, et al., 2009b). External experts are usually important for the provision of general knowledge of theories (including concepts, models and approaches). This knowledge has to be complemented with knowledge about specific conditions and practices, which can be provided by experts and stakeholders that originate from the country or the specific area (Gummesson, 2000; Vinke-de Kruijf, 2009b). Various actors can provide relevant knowledge of different aspects, including: (1) substantive knowledge concerning problems and potential solutions; (2) procedural knowledge related to the organization and management of the process (e.g. the facilitation of meetings); and (3) political knowledge that concerns the policy network (e.g. relevant social groups and power relations) (Leeuwis \& Van den Ban, 2004; Wesselink, et al., 2009). It is likely that various actors have diverging levels of knowledge in these various domains. They may have no knowledge, sufficient knowledge to interact interestingly with experts in that domain (interactional knowledge) or enough knowledge to contribute to that domain 
(contributory knowledge). Interactional knowledge is especially valuable if a project involves actors that are expert in different domains. In such situations, actors with interactional knowledge in multiple domains can translate between them. Actors with no knowledge may also have a role in this as they may still be able to judge expert knowledge on the basis of what they know about the level of social consensus that has been reached on that topic (Collins \& Evans, 2002). Although these knowledge levels are associated with substantive knowledge, they equally apply to an actors' level of knowledge about the specific context, the policy network or process management. In fact, persons do not need to have any substantive expertise in order to contribute to the knowledge transfer process. An actor may also have social knowledge that is embedded in social networks or relationships. Social networks are the means by which individual knowledge is connected to a larger body of knowledge and through which individual knowledge can be accessed by others (Trott, et al., 1995). Actors can, for example, act as 'knowledge brokers' by using their knowledge about the expertise, capabilities and availabilities of actors in their network to create linkages between knowledge seekers and experts (Boh, 2007).

\subsection{Pilot implementation of FLIWAS in Romania}

\section{Background, objectives and the interactive process}

Romania is a country in Central-Southeastern Europe and located in the Danube River basin. During the last decade, floods have become a yearly recurring issue in this country. Because of their frequency and intensity, floods currently represent the most important natural risk. The modernization of information systems is an important means to reduce flood risks (GoR, 2007a). Within this context, Romania participated in a project on the development of a computer-based flood information system for countries located in the Danube River basin. During this project, contacts were established between a Romanian expert and the Dutch project leader of the FLIWAS project. These contacts formed the basis of the Dutch-Romanian pilot project. Especially compared to Romania, floods occur with a very low frequency in the Netherlands. However, the development of flood forecasting and warning systems is still of crucial importance as more than half of the Netherlands is located in flood prone areas (Parker \& Fordham, 1996). The international transfer of water-related knowledge is important for the Dutch water sector and actively supported by the Dutch government. The pilot implementation of FLIWAS was supported by 'Partners for Water', which is a program that supports innovative projects of the Dutch water sector abroad. The main reasons for giving this support are: (1) to contribute to the solving of water-related problems in the benefiting country; and (2) to generate follow-up projects for the Dutch water sector (Min. V\&W, 2009). The general purposes of Dutchfunded projects are therefore problem-solving and the generation of follow-up projects (Chapter 3). 
The specific objective of the pilot was to support Romanian water authorities with the implementation of FLIWAS in Romania, so that they would be able to use, operate and maintain it independently. The project included three components: (1) development of a Romanian FLIWAS environment; (2) implementation of FLIWAS in a pilot area; and (3) dissemination of the project results among regional, national and international organizations with a role in flood risk management. These components were implemented in the period between September 2009 and April 2010. The project included five missions by Dutch experts to Romania with a length varying from four to twelve days. An overview of the period, goals and activities of these missions is presented in Table 4.1. Each mission included a visit to the pilot region and three of them also included a visit to Bucharest (home base of the national water authorities). As all key experts were speaking English, most of the small-scale meetings were in English. If necessary, English-Romanian translation was provided by Romanian actors involved. The remainder of this section introduces the actors involved and their knowledge background. Subsequently, the implementation of various project components is elaborated.

Table 4.1 - Overview of project activities

\begin{tabular}{|c|c|c|}
\hline Activity & Period & Main activities \\
\hline Mission 1 & Sept. '09 & $\begin{array}{l}\text { Regional and national kick-off meeting (to reach an agreement about } \\
\text { the implementation process); visit to the pilot area. }\end{array}$ \\
\hline Mission 2 & $\begin{array}{l}\text { Oct-Nov. } \\
\text { ‘09 }\end{array}$ & $\begin{array}{l}\text { Training for potential administrators; meeting with regional } \\
\text { stakeholders (to inform and consult). }\end{array}$ \\
\hline Mission 3 & Dec. ‘09 & $\begin{array}{l}\text { Support the regional implementation process; regional and national } \\
\text { progress meetings. }\end{array}$ \\
\hline Mission 4 & March '10 & Training of potential users; regional progress meetings. \\
\hline Mission 5 & April '10 & $\begin{array}{l}\text { Regional exercise; national conference; national meetings about } \\
\text { potential follow-up activities. }\end{array}$ \\
\hline
\end{tabular}

\section{Knowledge and backgrounds of key actors}

The project was implemented in collaboration between: (1) a consortium of three organizations (i.e. Dutch Foundation for Applied Water Research (STOWA) and the consultancy companies $\mathrm{HKV}_{\text {CONSULTANTS }}(\mathrm{HKV})$ and Royal Haskoning) that was supported by a Dutch funding agency; and (2) a team of Romanian experts and managers/decisionmakers that represented four Romanian authorities with a role in flood risk management. STOWA had been involved in the development of FLIWAS and hosted, until the end of 2010, the Dutch FLIWAS server. It was formally responsible for project management but did not directly contribute to the pilot implementation in Romania. HKV was involved with three experts who took care of operational project management and technical implementation. The initial project leader (who led the project in 2009) had limited international experience but was an expert in FLIWAS. The project leader was assisted and 
later replaced by an expert in river management. Until the project, this deputy and interim project leader was not familiar with FLIWAS but he had been involved in various international projects, including a Dutch-Romanian project on flood risk management in the pilot area (period 2006-2008). The third HKV expert had some expertise in FLIWAS but no international project experience. Royal Haskoning was involved with two Dutch experts one based in the Netherlands and one based in Romania - and one Romanian expert and responsible for project communication and dissemination. The Haskoning Netherlands expert had an education in water management, some knowledge of tools like FLIWAS and was experienced in international projects and in communicating the results of technicaloriented projects. The other Dutch expert of Haskoning Romania had extensive experience in international water projects and several years of Romanian project experience. The Romanian expert of Haskoning Romania (the project secretary) was educated in the communication domain and used to work in Dutch-Romanian projects. Both experts of Haskoning Romania were based in Bucharest and did not work in the pilot area or on Romanian flood risk management projects before.

The Romanian team consisted of: (1) the Department for Emergency Situations Management (DESM) of the Ministry of Environment (MEF), which coordinates and develops flood risk management policies; (2) the National Administration for Romanian Waters (NARW), which implements flood risk management policies; (3) Regional Water Branch (RWB) Banat, which is one of the eleven branches of NARW; and (4) the National Institute for Hydrology and Water Management (NIHWM), which studies and monitors water resources. The first two organizations were involved as responsible authorities and had a supportive role. RWB-Banat participated with various experts who contributed context-specific knowledge, for example, on the water system, the emergency plans or communication. Two experts of the International Department had international project experience and coordinated, respectively, technical implementation and communication activities. An expert of Dispatch (department in which hydrological and meteorological data is collected and emergency plans are coordinated) and an expert of International helped to integrate data into FLIWAS and were expert in flood risk management. NIHWM was involved with four experts, who raised the attention for the project and contributed knowledge on flood risk management (providing information and participating in trainings), communication (contributing to dissemination) and information technology (IT) (taking care of the installation of the server. Directors of RWB-Banat and NIHWM both actively supported the project. The contributions of various organizations are also summarized in Table 4.2. 
Table 4.2 - Key organizations, their role and the expertise of experts involved

\begin{tabular}{|c|c|c|}
\hline Organization & Role & Expertise/background of experts involved \\
\hline STOWA & Indirectly (project management) & $\begin{array}{l}\text { Development of FLIWAS and hosting the } \\
\text { Dutch server. }\end{array}$ \\
\hline HKV & $\begin{array}{l}\text { Operational project management } \\
\text { and technical implementation }\end{array}$ & $\begin{array}{l}\text { FLIWAS (limited to extensive) and flood risk } \\
\text { management in the pilot region (one expert). }\end{array}$ \\
\hline $\begin{array}{l}\text { Royal } \\
\text { Haskoning }\end{array}$ & $\begin{array}{l}\text { Communication and } \\
\text { dissemination }\end{array}$ & $\begin{array}{l}\text { Romanian context (and language), } \\
\text { communication and international projects. }\end{array}$ \\
\hline DESM & Dissemination and support & Policy development (national and European). \\
\hline NARW & Dissemination and support & Policy implementation (national). \\
\hline RWB-Banat & $\begin{array}{l}\text { Provision, collection and } \\
\text { integration of data and } \\
\text { communication }\end{array}$ & $\begin{array}{l}\text { Hydrology, flood risk data management, } \\
\text { cadastre, communication and international } \\
\text { cooperation. }\end{array}$ \\
\hline NIHWM & $\begin{array}{l}\text { Implementation of a Romanian } \\
\text { server, data provision and } \\
\text { communication }\end{array}$ & $\begin{array}{l}\text { Information technology, flood risk } \\
\text { management and communication. }\end{array}$ \\
\hline
\end{tabular}

\section{Development of the Romanian FLIWAS environment}

The objective of the pilot was to develop FLIWAS to such an extent that Romanian experts would be able to use, operate and maintain it independently. The following activities were undertaken in order to realize this objective: (1) the existing interface, training guide and user manual were translated into Romanian (done by RWB-Banat experts); (2) a Romanian server and an internet domain were realized by NIHWM; (3) potential users and administrators (experts of RWB-Banat and NIHWM) were trained by a HKV expert; (4) a workshop was organized in which about twenty potential users (of RWB-Banat, NIHWM, MEF, local authorities and regional emergency managers) could exercise the actual use of FLIWAS; and (5) Romanian authorities were offered to participate in the international structure for functional support and maintenance. Most of these activities were executed without problems. However, the realization of the server was troublesome. In the first mission, NIHWM and NARW both expressed that they could host the server but did not have a server that was meeting the requirements. It was agreed that NIHWM would arrange an adequate server and have it operational by the beginning of November 2009. Following the first mission, the IT expert of NIHWM arranged a server on the basis of specifications provided by HKV. As HKV experts did not have specific IT expertise, they could not answer specific questions about the required configuration and the operation system. This is also why HKV contracted a German consultancy company, which also had been involved in the development of FLIWAS, to install the software on distance. Mid-November, the project leader brought the IT expert of NIHWM and the German experts in contact with each other by email. The German experts answered several questions by email and 
subsequently tried to install FLIWAS on the server. When this attempt was not successful, experts involved had additional contact by email and by phone. However, the Romanian and German experts appeared to have difficulties in understanding each other. In December 2009, the project leader had a face-to-face meeting with the IT expert of NIHWM. In this meeting, he tried to understand and clarify the problems, among others, by visualizing the FLIWAS environment. Other Romanian experts involved also tried to translate between the IT expert, the project leader and the German experts. The IT expert of NIHWM also asked for assistance from other IT experts (also of NARW). Despite these efforts, the problems with the installation of FLIWAS persisted until the end of the project. Around March 2010, the interim project leader proposed to hire an external IT company. At this point, the NIHWM expert decided to redo the configuration all over again. This was successful and German experts were eventually able to install FLIWAS at the Romanian server in the beginning of April 2010. Although the FLIWAS environment was successfully installed on the server, it was never used no one has the intention to use it. National authorities expressed that, in case of any follow-up, they would purchase a new server with more capacity that would be hosted at MEF. The server was therefore also switched off some time after project completion.

\section{Pilot implementation of FLIWAS in the Banat region}

The pilot implementation concentrated on the lower Timiş River, which is located in Banat region in the Southwest of Romania. Failure of the dikes along this lowland river caused four major flood events in the period 1999-2006. An important reason for choosing this location was that this river was also studied in a previous Dutch-Romanian project. Hence, an expert of HKV and several RWB-Banat experts had specific knowledge on that part of the river basin and some maps and models were already available. In the pilot, additional information still had to be collected. Furthermore, all relevant information (e.g. flood maps, flood scenarios and emergency response plans) had to be codified in the right format in order to be integrated into FLIWAS. These activities were mostly done in collaboration between experts of HKV and various RWB-Banat departments. Communication between these experts was mostly face-to-face during missions. In between missions, they communicated by email (especially to exchange documents) and occasionally by phone or videophone. In the collection of geographic data, a Cadastre expert of RWB-Banat and a HKV expert had some problems to arrive at a shared understanding of what kind of information was needed. The problem was only solved in the fourth mission, when the interim project leader of HKV (who established a good relation with the cadastre expert during the previous project) asked for the data. Experts further experienced that there was sometimes a need to modify or to create information. For example, the coordinate system of maps had to be transformed, additional flood scenarios had to be developed (for the exercise) and the different reference levels that were used in Romanian emergency plans (of which summaries were translated into English) had to be dealt with. Further, it appeared to 
be unfeasible to automatically import data from RWB-Banat's automated measurement system into FLIWAS. Both systems used different formats and could only be connected if FLIWAS would be installed on the Romanian server. Since the installation of this server took much longer than expected, the pilot implementation was done at the Dutch server and data were never transferred from the Dutch to the Romanian server. Dutch experts expected that Romanian experts would transfer the data. However, Romanian experts did not know how to transfer data and expected others to do this. In November 2010, the Dutch server was upgraded and data of the pilot were removed. Later, the server was also moved from STOWA to another organization. However, also when the pilot data were still accessible, Romanian authorities never started using FLIWAS. What played a role in this was that one (out of two) of the key experts of RWB-Banat went on leave and that the automated import of measurements was never arranged. Dutch experts further mentioned that actors still had to implement the communication module (to support communication in case of emergencies), to organize a larger exercise and to train additional actors. Romanian experts also foresaw many practical bottlenecks towards the operational use of FLIWAS in the field (e.g. collapse of internet, a lack of trained personnel and a lack of communication tools). The extension of the pilot was also seen as potentially difficult, for example, because of the limited availability of hazard maps (no prerequisite but needed for visualization purposes) and the quality and number of automated measurement stations. Although the pilot proved, especially to Dutch experts, that FLIWAS was applicable in Romania, the region experts never started to actually use it.

\section{Dissemination of the project results}

To enhance the dissemination of the project results, experts of Royal Haskoning developed a communication plan that specified why, how and when project results would be disseminated among participating Romanian organizations, stakeholders in the pilot region (local and regional authorities with a role in the management of emergency situations) and others (water authorities in the Danube River basin, other specialists and the general public). Experts of Royal Haskoning, NIHWM and RWB-Banat discussed the communication activities regularly in face-to-face meetings and via email. In this process, the project secretary (a Romanian expert of Haskoning) fulfilled a key role. The overall progress and results of the pilot were communicated in various progress meetings at RWBBanat and NIHWM, which were well-attended by managers and employees. The actual involvement of NARW and MEF was limited and concentrated at the beginning and at the end of the project. Stakeholders were invited for a meeting and the exercise but had limited interest to participate. To inform others, the communication experts prepared promotion materials, such as posters and a booklet, press releases and website announcements. Various experts also prepared articles about the project and presented the project at various occasions for a regional, national and international public. Local, regional and national media also paid considerable attention to the project. At the end of the project, a final 
conference was organized and attended by all participating organizations, most branches of NARW and several other organizations. Furthermore, a face-to-face meeting was organized with the State Secretary for Water and several managing directors of participating organizations. The final conference and the last meeting resulted in several ideas for follow-up projects of which two were elaborated in concrete proposals.

\subsection{Results \& discussion}

Central in the presented project was the transfer of the FLIWAS concept, as it had been developed for the Rhine River basin, to Romania. The case study involved a wide variety of experts, managers, decision-makers and stakeholders but its knowledge orientation was expert-driven in the sense that the focus was on knowledge creation and learning among experts (Vreugdenhil, et al., 2010). All communication with other actors was focusing more on information provision and consultation than on active collaboration. Experts tried to actively involve stakeholders (e.g. by inviting a selection of local and regional stakeholders for a stakeholder meeting and the exercise) but their interest and/or capacity to contribute with their knowledge appeared to be limited. This did not impose a problem as relevant context-specific substantive knowledge could also be provided by the experts involved. However, before the regional water authority could start using FLIWAS it probably needs to involve other actors with a role in emergency situations more closely. Actors with management and decision-making capacities were regularly informed and consulted about the design, the progress and the dissemination of the pilot. In terms of knowledge, these actors contributed 'inside' political and procedural knowledge, while Romanian experts contributed context-specific substantive knowledge. This knowledge was integrated with substantive, political and procedural knowledge of Dutch experts, which was mostly of generic nature. The case study confirms that besides substantive knowledge, also procedural and political knowledge are relevant in (international) flood risk management projects (Wesselink, et al., 2009).

The case study illustrates that international projects tend to involve actors with diverse socio-cultural, organizational and professional backgrounds (Stenmark, 2002). There were two occasions in which this caused that experts had difficulties to understand each other, even though they were speaking the same language. One instance was the installation of the server for which key experts were supposed to collaborate on distance. Due to their diverging backgrounds, experts had no common knowledge base and should preferably have spend time with each other to allow for the provision of background information (Stenmark, 2002). This was not done and experts involved appeared to have different assumptions and understandings of the specific expertise that was required and available. This confirms that in a project environment, it is highly important that actors have a shared vision on what needs to be done, by whom and how (Bresnen, et al., 2003). For the implementation of other project components, face-to-face communication was mostly used to develop common understandings. This is also the most effective means to share 
knowledge in a project context (Koskinen, et al., 2003). The second occasion on which experts had difficulties to understand each other was the collection of geographic information. Despite their face-to-face interaction, the Dutch and the Romanian expert involved failed to arrive at a shared understanding. The interim project leader - who developed a good relationship with the Romanian expert in a previous project - eventually intervened and was able to solve the problem. According to actors involved, the good relations between this Dutch expert and various Romanian experts also eased the overall knowledge transfer process. This confirms that interpersonal and social aspects are of crucial importance in knowledge management (Bresman, et al., 1999). What made the transfer of knowledge in the pilot area also relatively easy was that there was close cooperation in teams. Literature shows that 'happy teams' and good working relationships foster knowledge transfer (Trott, et al., 1995) and that team work also contributes to the development of a shared understanding and mutual trust (Nonaka, 1994). What probably also enhanced the transfer of knowledge was the exercise as it allowed for 'reflection-inaction'. It gave actors the opportunity to gain hands-on-experience and also to reflect on this experience in interaction with others (Nonaka, 1994; Schon, 1983). Experts involved further mentioned that the codification of information also contributed to their understanding of the situation. This shows that codification is not only useful to make knowledge available to others (Boh, 2007) but can also help to arrive at deeper and/or shared understandings.

On the basis of literature, we further expect that knowledge transfer benefits from the involvement of actors with social or interactional knowledge. Actors involved in the case study confirmed that implementation was enhanced by the involvement of several experts who had 'inside' knowledge on one socio-cultural setting and - due to previous experiences - interactional knowledge on the other setting. What eased the collection of data in the pilot area was that one expert could fulfil the role of 'knowledge broker' as he knew which experts at RWB-Banat were having what knowledge. Such brokers are especially relevant in fragmented environments (Boh, 2007; Bresnen, et al., 2003). In terms of knowledge levels, the case study involved experts with high, intermediate and no contributory knowledge in various domains. One of the experts suggested, and literature confirms, that the advanced knowledge level of an expert on FLIWAS facilitated the knowledge transfer. However, experts with advanced knowledge also tend to provide instruction at a level of abstraction that is difficult to absorb for beginners (Hinds et al., 2001). In such situations, experts with interactional knowledge may be able to translate between experts (Collins \& Evans, 2002). In the case study, it happened at several occasions that experts with interactional knowledge about a certain topic or context started to translate between experts who had difficulties to understand each other. Interactional knowledge was probably one of the factors that helped to solve the problems in the collection of geographic data. Experts with interactional knowledge also tried to mediate between experts involved in the installation of the server. Although the attempts were appreciated, it is questionable if this 
also contributed to the knowledge transfer. Further research is needed to confirm whether and how various forms of interactional knowledge have a positive effect on international knowledge transfers. The case study further highlights that an actors' ability to effectively transfer knowledge is not only rooted in education and experience but also in personal characteristics or attributes, such as intuition, human understanding, stress toleration and creativity (Gummesson, 2000; Koskinen, et al., 2003). For example, the interim project leader appeared to have a great capability to solve problems between experts and to develop and maintain relationships. This eased the cooperation and thus the knowledge transfer.

Overall, the knowledge transfer in the case study has not been very effective. Romanian actors were generally positive about the pilot and interested in follow-up but did not yet start using or further implementing FLIWAS. This implies that the project did not contribute to the reduction of flood risks but that follow-up projects may come in time. These outcomes confirm that successful knowledge sharing and acquisition do not necessarily lead to application. Factors that may play a role in this are: a lack of trust or respect in the knowledge source, resistance to change, risk aversion, lack of time and lack of opportunity (Davenport \& Prusak, 1998). It is argued that 'champions' are of particular importance for the successful adoption of knowledge. Champions are key players that are able to promote and push the adoption of new ideas (Trott, et al., 1995). In the case study, the managers and decision-makers actively supported the pilot, which probably enhanced its implementation. However, they also perceived the pilot rather as a basis for follow-up than a basis for the actual use of FLIWAS. For them, the pilot was thus rather a means to explore and to influence decision-processes than to mitigate problems (Vreugdenhil, et al., 2010). This highlights that the presented analysis of actors, their interaction and knowledge can only partly explain the knowledge transfer process and its outcomes. To gain a more complete understanding of such processes, a more detailed analysis of the project context and the resources, cognitions and motivations of actors involved is needed (Bressers, 2007; Chapter 3).

\subsection{Conclusions}

The aim of this chapter is to provide new insights in how interaction and knowledge influence the effectiveness of an international knowledge transfer process. For this, we integrated theoretical insights into a conceptual model, which we applied to a case study. Central in the case study was the transfer of FLIWAS from the Netherlands to Romania. It illustrated that international flood management projects tend to involve a wide variety of actors with different levels and types of knowledge. This creates a great potential for knowledge transfer but may also be a complicating factor. Also due to their diverging socio-cultural, professional and organizational backgrounds, actors may have serious difficulties to understand each other. In such situations, face-to-face interaction is crucial to also communicate the tacit aspects of knowledge. However, the case study also shows that personal communication means may not be sufficient to overcome differences in 
knowledge backgrounds. Factors that eased the knowledge transfer included the active collaboration in teams, the possibility for 'reflection-in-action' in interaction with others and the process of codifying knowledge. Other factors that eased the process were interpersonal aspects and the capacity to develop relations. Further research is needed to better understand whether and how social knowledge and interactional knowledge enhance knowledge transfer. In the case study, the sharing and acquisition of knowledge was only partly successful. Actors became willing to initiate follow-up projects but are not using the pilot results. These outcomes cannot be explained fully by the presented analysis and would require a further analysis of the actors and context of a knowledge transfer process. 


\section{Chapter 5}

\section{Case study C: Learning in an Integrated Water Management project}

This chapter reflects on the role of learning in the projects under study. Insights about social learning in natural resources management are reflected upon using the experiences of the third case study. A revised version of this chapter is planned to be published as: Vinkede Kruijf, J., Bressers, H. T. A., \& Augustijn, D. C. M. (accepted). How Social Learning Influences Further Collaboration: Experiences from an International Collaborative Water Project, Ecology and Society.

\section{ABSTRACT}

Social learning plays an important role in the solving of water management problems. This chapter analyses the nature and effects of learning in an international collaborative setting. We assert that interactive processes are shaped by the characteristics, which are the motivations, cognitions and resources, of actors involved. Interactions contribute to two types of social learning: relational and substantive learning. Learning processes change actor characteristics and contribute to the development of collective outcomes on which further collaboration can be based. We apply these insights to a case study, which is a water project that was implemented by Dutch and Romanian actors in Romania. The actors involved learnt different things but the project did not provide a basis for further collaboration. The case study demonstrates that interactions between actors may contribute to constructive learning but can also have the opposite effect. We conclude that a single international collaborative project includes multiple and diverse social learning processes. Whose learning has most impact closely relates to how resources are distributed across actors. Thus, whether learning forms a basis for further collaboration depends not only on 'how much' actors learn but in particular on 'who learns what'.

\subsection{Introduction}

Water management problems are embedded in a complex social and natural environment. The management of water resources affects a wide variety of uses and users with diverse perspectives and involves high levels of uncertainty. As a result, water problems are often complex and unstructured (Hommes, et al., 2009b; Huitema et al., 2010). The literature on social learning in water resources management shows that learning by interacting with 
others can play an important role in solving such problems (Gerlak \& Heikkila, 2011; Huitema, et al., 2010; Muro \& Jeffrey, 2008; Pahl-Wostl, et al., 2007a; Schusler et al., 2003; Steyaert \& Jiggins, 2007). Although actors cannot be forced to engage in learning processes, it is possible to create interactive settings that facilitate learning (Rist et al., 2006; Schusler, et al., 2003). In such settings, actors can learn from each other by sharing and reflecting upon different perspectives and types of knowledge. This contributes, for example, to the development of 'negotiated knowledge' - i.e. knowledge for which actors agree about its significance, meaning and (scientific) validity - about the problem and its solutions (Hommes, et al., 2009b; Koppenjan \& Klijn, 2004). Social learning may result in a common understanding and mutual agreement and also lead to the acquisition of skills, changes in attitudes and cognitions, relations and trust (Muro \& Jeffrey, 2008).

This chapter focuses on learning in an international water project, which is seen as an interactive process in which actors of different countries collaborate to solve a water problem. International water projects may be implemented by actors of different countries who share the same river basin. In a river basin management context, the recognition of the mutual dependencies between actors is an important aspect of social learning (Tàbara \& Pahl-Wostl, 2007). In addition, international water projects can take the form of a policy or knowledge transfer process, as is the case for the project that is presented in this chapter. In these projects, actors are not dependent on the same resource but have other reasons to collaborate. Reasons for engaging in such processes are the desire to solve a problem, to become more effective or efficient, to legitimize actions, to attract additional financial resources or to sell success stories (Marsden \& Stead, 2011). Also in projects that involve the transfer of knowledge, actors can depend on each other's resources. This can be the case when actors of two different countries come together to solve a water management problem: one country can contribute with finances and knowledge but lacks authority and context-specific knowledge whereas the other country lacks the capacity to solve the problem (see Chapter 3). International projects differ from other collaborative settings. They offer additional opportunities for learning but also involve actors with diverse organizational, professional and socioeconomic backgrounds who therefore often have difficulties to understand each other (Stenmark, 2002). Despite such difficulties, also in an international setting, interactions may contribute to the development of more overlapping views, mutual trust and a willingness to collaborate more closely (Rist, et al., 2006). While 'bringing actors closer together' is an important outcome of collaborative environmental projects, they are not designed for this purpose. Their actual purpose is usually to realize environmental outcomes, such as flood risk reduction or improved water quality (Koontz \& Thomas, 2006; Mandarano, 2008). Thus, the results of a social learning process are typically a basis on which actors can decide to continue their collaborative actions for problem solving.

The concept of social learning has become very popular in recent years and is seen as an important means of dealing with complex and uncertain environmental problems (see e.g. 
Ison et al., 2007; Maarleveld \& Dabgbégnon, 1999; Muro \& Jeffrey, 2008; Pahl-Wostl, et al., 2007a). Despite the growing body of literature, there still remains much to learn about the relation between interactive processes and the development of a shared understanding on which agreement and action can be based (Muro \& Jeffrey, 2008). Therefore, the central questions of this chapter are: What are the nature and effects of social learning? To what extent does social learning contribute to further collaboration in international collaborative settings? To answer these research questions, we build upon the scholarly literature about social learning and policy implementation and the experiences of an international water project. Social learning refers here to the learning that occurs when actors engage in an interactive process (i.e. a process in which multiple actors undertake a series of activities to realize certain objectives). We assert that the course and outcomes of such a process are shaped by the characteristics of actors involved (De Boer \& Bressers, 2011). In an interactive process, these characteristics change as a result of learning. This may contribute to the development of collective outcomes on which future collaborative actions can be based. We apply these insights to a case study, which is a project that was implemented in collaboration between a team of Dutch (external) actors and Romanian (local and regional) actors. The next section explains our understanding of learning in collaborative settings. We then introduce the case study and research methods. The subsequent section explains how, in the case, actor characteristics changed as a result of learning. On the basis of the case study, we further discuss the relation between social learning and further collaboration. The last section presents our main conclusions on the nature and effects of social learning.

\subsection{Learning in collaborative settings}

To understand the nature and effects of learning, we depart from a theory on policy implementation: the Contextual Interaction Theory. The main starting-point of this theory is that interactive processes are shaped by the characteristics of the actors involved, which are their motivations, cognitions and resources (Bressers, 2009; De Boer \& Bressers, 2011). Actors are defined here as individual persons that mainly act as representative of an organization or collective entity (Newig et al., 2010). Actors' motivations drive their actions and are reflected in their willingness to participate in a collaborative process. They are rooted in personal and organizational goals and values and influenced by external pressures (e.g. social, political or economic) and self-effectiveness assessment (i.e. whether an actor perceives that it is within its capacity to perform as desired). The concept of selfeffectiveness assessment is based on the recognition that competent functioning requires skills as well as the belief that one is capable of using these skills to accomplish a certain performance (Bandura, 1986). Cognitions refer to the information an actor holds to be true. They are rooted in an actors' interpretation of reality, which is influenced by frames of reference and observations of reality. Cognitions are reflected in an actor's formulation of the problem (e.g. the nature, meaning and urgency of the problem at stake and its potential solutions) and the process (e.g. the relevance and potential of the adopted or proposed 
approach). Resources refer to the capacity of an actor to act and are - in a relational setting - also sources of power. It includes human resources (skilled people), knowledge resources (information, data and knowledge), financial resources and institutional resources (power to get things done) (Owens, 2008; Vinke-de Kruijf, 2011b). There are mutual relations between the process and actor characteristics. This means that characteristics shape the process and are also shaped by the process. In addition, every change in one of the characteristics influences the other two (De Boer \& Bressers, 2011; Owens, 2008).

Learning involves an increase of knowledge and insights as well as the growing capacity of an actor to make use of its knowledge, experience and understanding (Bierly et al., 2000; Leeuwis \& Van den Ban, 2004). This growing capacity is also referred to as an increase in skills or qualities (Muro \& Jeffrey, 2008; Pahl-Wostl, et al., 2007a). Social learning can be divided into substantive learning and relational learning (including institutional learning) (Huitema, et al., 2010; Koppenjan \& Klijn, 2004; Pahl-Wostl, et al., 2007a; Schusler, et al., 2003). Substantive learning involves the acquisition of factual knowledge that leads to an increase of knowledge and insights about the problem and its solutions (Huitema, et al., 2010; Koppenjan \& Klijn, 2004) as well as the acquisition of technical skills or qualities (Muro \& Jeffrey, 2008; Pahl-Wostl, et al., 2007a). Relational learning involves an increase of knowledge and insight in the role of other actors and mutual dependencies as well as the ability of actors to develop relations, mutual trust and shared meanings that potentially support their interaction (Koppenjan \& Klijn, 2004). This form of learning is closely related to the development of relational qualities (Pahl-Wostl, et al., 2007a), enhanced trust and improved understanding of other actors' perspectives (Huitema, et al., 2010). Central in social learning theories is further the notion that - in interaction with others - actors learn not only at the individual level but also at the collective level (De Laat \& Simons, 2002; Gerlak \& Heikkila, 2011; Newig, et al., 2010). The transmission of knowledge across individuals may involve changes at the collective level and lead to collective outcomes, such as shared ideas, rules or policies (Gerlak \& Heikkila, 2011; Newig, et al., 2010).

In this chapter, we associate learning at the individual and at the collective level with changes in actor characteristics. While learning is often seen as a cognitive change, the mutual relations between the three variables imply that a change in cognitions also changes motivations and resources (De Boer \& Bressers, 2011). Constructive interaction leads to the development of a consistent set of values, common reference frames and pooling of resources. In addition, it contributes to the development of a collective resource: trust (Bressers, 2009). Trust refers to someone's “intention to accept vulnerability based upon positive expectations of the intentions or behaviour of another" (Rousseau et al. 1998: 395). Trust becomes relevant when an actor needs to take risks and depends on other actors. In relatively new relations, the willingness of actors to trust is generally limited, since trust is based only on information that is, for example, provided by others or by certification. When actors interact with each other over a longer period of time, they gain additional information about other actors that is rooted in relational experiences. Positive relational 
experiences increase an actors' willingness to trust another actor. Negative experiences have the opposite effect (Rousseau, et al., 1998). Mutual trust can be a strong motivational factor and accelerate collaboration processes (De Boer \& Bressers, 2011).

As explained in the Introduction, environmental projects are typically designed to solve a concrete problem. The achievement of environmental outcomes is closely related to the development of collective outcomes: environmental objectives are more likely to be achieved when actors arrive at common basis for further collaborative actions. Such a basis is created when actors develop a joint motivating goal, create a negotiated knowledge base, mobilize required resources (by pooling them, if necessary) and have positive relational experiences (as a basis for trust) (see Chapter 3). Figure 5.1 integrates these ideas about learning into a conceptual model. It shows that social learning changes individual actor characteristics and may contribute to the development of collective outcomes. Collective outcomes form a basis for collaborative follow-up actions that are needed to achieve environmental objectives.

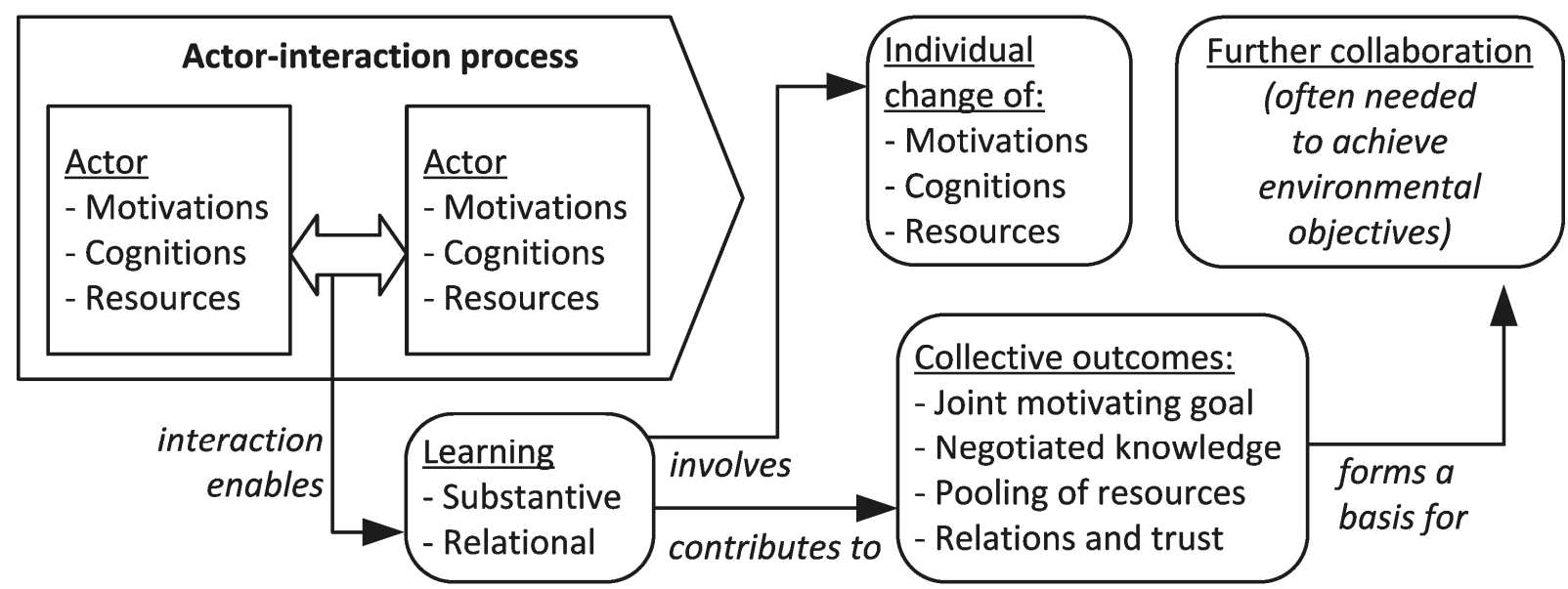

Figure 5.1 - Conceptual model of the relation between learning and actor characteristics in actor-interaction processes

\subsection{Case study project and methods}

\section{Case study: an international water project}

To better understand the nature and effects of learning in international collaborative settings, we examined the project "Integrated Water Management for the Tecucel River basin". The Tecucel is a small river (length of circa $25 \mathrm{~km}$ ) in the Danube River basin in Romania. In September 2007, a flash flood on this river caused three deaths and an economic damage of circa 6 million Euros in the city of Tecuci and several neighbouring communities (Zaharia et al., 2008). The flood also had a major impact on the delivery of water services. Recognizing that floods and water services problems are often - at least partly - interconnected, the project aimed to develop a master plan that would integrate both. The initiative for the project came from the Dutch regional water board Hunze \& 
Aa's, which was informed about the flood by a Romanian intern. Following an exploratory visit to the area, the water board started to develop a project with five other organizations in the North of the Netherlands: the municipality of Groningen, water company Groningen, the Dutch Governmental Service for Land and Water Management (DLG), a consultancy company and a production company (which produces, among others, units for wastewater treatment). DLG was asked to take care of all project management tasks. In May 2008, the Dutch project team paid a preparatory visit to the project area and met with various regional and local actors. This formed the basis for the further development of the project proposal and the mobilization of finances. The project costs were partly covered by the bank of the Dutch water boards and partly by the Dutch organizations involved. To create the necessary financial and organizational commitment, a steering group was formed with high-level representatives of the participating organizations. At the Romanian side, a local project team was formed with representatives of the City of Tecuci, two neighbouring communities, the water company of Tecuci and a local office of the regional water authority. The team was chaired by a civil servant of Tecuci and supported by a project secretary (former intern of the Dutch water board, employed at another municipality) and a technical assistant (employee of a Romanian consultancy, which was a sister company of the Dutch consultancy). Furthermore, a consultative committee was formed with high-level representatives of national, regional and local authorities. The project structure is schematized in Figure 5.2.

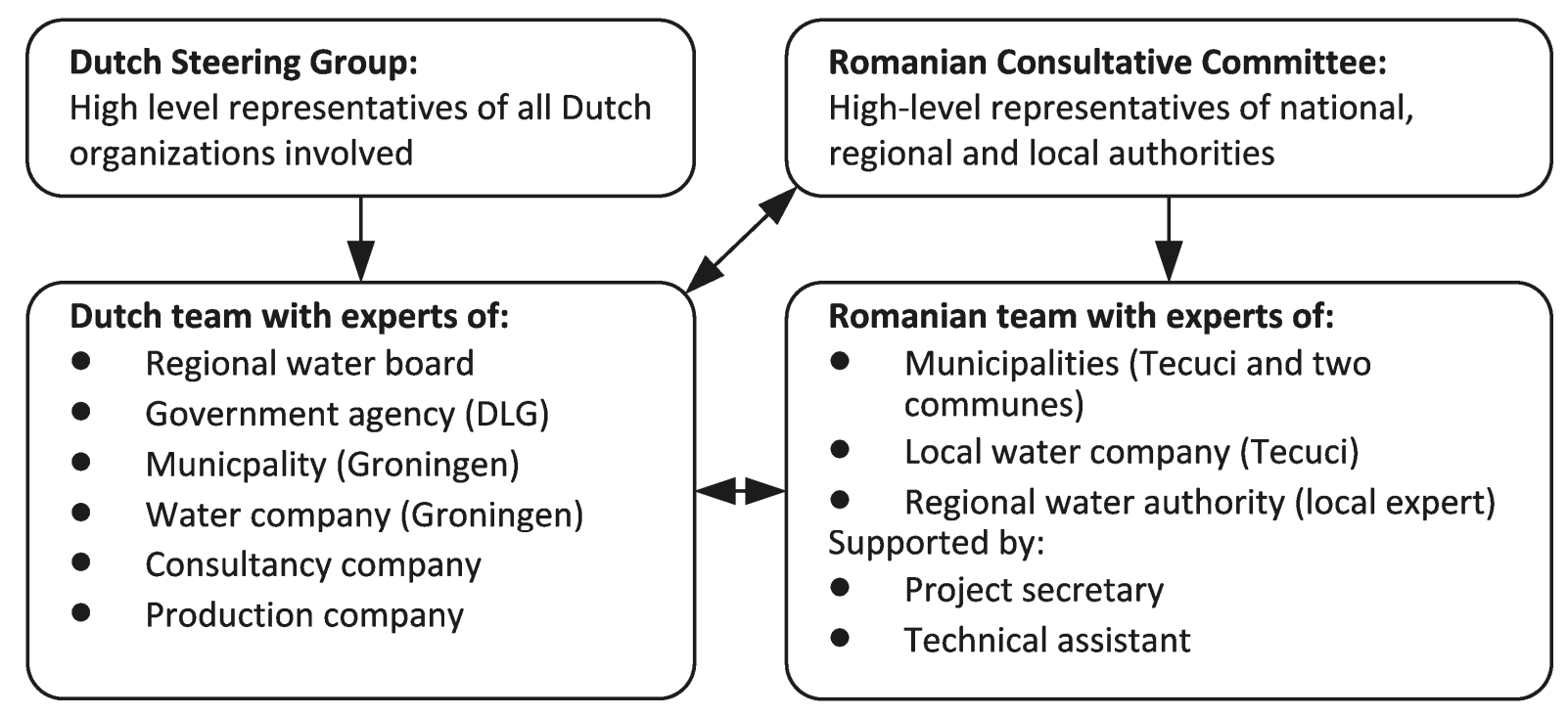

Figure 5.2 - Project structure: a Dutch steering group and team and a Romanian consultative committee and team

The ultimate project goals were to improve the water system and the living conditions of the population in the Tecucel River basin and also to develop a long-term cooperation and to exchange knowledge between Dutch and Romanian actors involved. The project was divided into four phases: (1) analysing the existing situation and developing an action plan for the project; (2) identifying "no regret" measures (i.e. measures that would contribute to the realization of a more sustainable water system and could be implemented relatively 
easy); (3) creating institutional and financial support and commitment for a program of measures; and (4) preparing a master plan including no-regret measures. The project was not implemented as planned since the project teams concluded halfway through the project that the completion of two regional master plans - developed to bring water management in line with European standards - made the development of another master plan redundant. The project area was part of the region that was addressed in both plans of which one focused on flood risk management and one on water services. One plan was drafted by the regional water authority within the context of the European Floods Directive (2007/60/EC). The other plan was drafted by the regional water company (Apa-Canal Galaţi) within the context of the European Directives on drinking water (98/83/EC) and wastewater (91/271/EEC). To improve the management of water services, the water company of Tecuci was integrated into this regional company in October 2010. Several members of both project teams were aware that master plans were being developed. However, they only realized halfway through the project how the plans impacted the project goals. Towards the end of the project, the Dutch team decided to focus more on the identification and development of no-regret measures and on the possibilities for further collaboration with the regional water company and water authority. In the end, none of the identified no-regret measures appeared to be feasible but the Dutch water company and water board decided to engage in a 'water partnership' with the regional water company for a period of three years.

The project was implemented between September 2009 and June 2011. In this period, Dutch actors went for six 'missions' to Romania and Romanian actors went for two 'visits' to the Netherlands (see Table 5.1 for an overview). The length of these visits and missions (i.e. actual time spent with the other actors) varied between one and five days. The Dutch missions to Romania included three visits to the project area (missions 1, 2 and 6), two visits to Galaţi (missions 3 and 4) and one visit to Iaşi (mission 5). The Romanian visits to the Netherlands include a study visit by the project team and a representative of the Municipality of Galaţi (visit 1) and a visit by two representatives of the regional water company to discuss further collaboration (visit 2). In addition, the Dutch team met on a regular basis (about once a month) to discuss progress and so did the Romanian team. Contact between both teams went mostly via the Dutch project leader and the Romanian project secretary who had regular contact via email and phone. The interaction with highlevel representatives was limited: the steering group met once in the preparation period and the consultative committee once with the Romanian team and once with both teams in the implementation period. In addition, there was some contact with other actors, such as nongovernmental organizations and consultancy companies. 
Table 5.1 - Overview of missions by Dutch actors to Romania and (study) visits by Romanian actors to the Netherlands

\begin{tabular}{lll}
\hline Activity & Period & Scope, participants and activities of various missions and visits \\
\hline Mission 1 & Oct. '09 & $\begin{array}{l}\text { Dutch team visits Tecuci to discuss the project content and organization } \\
\text { in plenary and small-scale meetings and to visit the project area; two } \\
\text { Dutch actors visit the water company and county council of Galaţi }\end{array}$ \\
Visit 1 & Dec. '09 & $\begin{array}{l}\text { Romanian team visits Groningen area to further define the process in } \\
\text { plenary meetings and interactive workshops and to visit the region }\end{array}$ \\
Mission 2 & June '10 & $\begin{array}{l}\text { Dutch team visits Tecuci to discuss the project progress and goals with } \\
\text { the Romanian team in plenary meetings and workshops }\end{array}$ \\
Mission 3 & Sept. '10 & $\begin{array}{l}\text { Three Dutch actors visit a Dutch-Romanian workshop on flood risk } \\
\text { management in Galaţi }\end{array}$ \\
Mission 4 & Oct. '10 & $\begin{array}{l}\text { Two Dutch actors visit the water company in Galaţi to discuss future } \\
\text { collaboration } \\
\text { Water company Galaţi visits three Dutch actors to discuss future }\end{array}$ \\
Visit 2 & Nov. '10 & $\begin{array}{l}\text { Wallaboration } \\
\text { cols }\end{array}$ \\
Mission 5 & Feb '11 & $\begin{array}{l}\text { Dutch consultant visits regional water authority to discuss future } \\
\text { collaboration } \\
\text { Dutch team visits water company in Galaţi to discuss future } \\
\text { collaboration and Tecuci to evaluate the project with the Romanian } \\
\text { team }\end{array}$ \\
\hline
\end{tabular}

\section{Methods}

Qualitative data about the case were collected by the first author, who was the principal researcher, between March 2008 and July 2011. She used multiple methods to collect data about the project (i.e. its context, objectives, collaboration structure and activities) and about the actors involved (i.e. their motivations, cognitions, resources and relations). During the entire project, the researcher participated as observer. She collected observational data about four missions (1, 2, 3 and 6) and about the first visit. During and between these activities, the researcher had regular contact with key informants. In June and July 2011 (shortly after the project was finalized), she conducted semi-structured interviews with six members of the Dutch team (in Dutch) and nine Romanian actors (in English or in Romanian with translation into English). In addition, the researcher analysed a wide variety of project documents (plans, minutes, reports, letters and emails), policy documents (legislation, policies, plans and strategies) and other relevant material (such as websites). Collected data were structured using software for qualitative analysis (ATLAS.ti). Based on these data, a detailed narrative of the case was prepared in the form of a case report (Vinke-de Kruijf, 2012). Draft versions of the interview reports and the case report were reviewed and, if applicable, corrected by respondents and key informants. 
To develop an understanding of the learning processes, we analysed the overall process and actors' motivations, cognitions, resources and relations at various points in time. The observed changes in actor characteristics were examined from a social learning perspective. This means that we analysed not only the individual changes in motivations, cognitions and resources, but also the emergence of outcomes on which further collaborative actions can be based. Collective outcomes are associated with changes in actor characteristics and with the development of relations and trust (an additional collective outcome). Accordingly, the results section is organized along four lines of understanding: (1) motivations and the construction of a joint motivating goal; (2) cognitions and the creation of negotiated knowledge; (3) resources and pooling of resources; and (4) mutual relations and an increased willingness to trust.

\subsection{Case study results}

\section{Motivations and a joint motivating goal}

The Dutch organizations had various reasons to participate in the project. Among the most important reasons were commitments to the realization of the Millennium Development Goal on water and sanitation, the creation of business opportunities and improved collaboration with other actors in the North of the Netherlands. Personal reasons included being involved in an interesting project and also to really contribute with one's knowledge or network to the solving of problems in the area. The latter shows that some actors had a very positive self-effectiveness assessment. This did not apply to all of them; some also doubted whether their organization should be involved in international water projects. The interaction with Romanian actors had a demotivating effect - especially on Dutch experts who really wanted to do something concrete. Unmet expectations and learning explain this effect. What played a role was that Romanian actors were more passive and awaiting (which made Dutch experts doubt their motivations) and had less insights in and influence on policy processes than expected (which made Dutch experts feel misinformed). Further, the project gave the Dutch team new insights into the regional master plans and the policy network. As a result, they became increasingly aware (collectively) that they could not achieve concrete outcomes. Individual learning processes also impacted the motivations, both in positive and negative ways. For example, the consultancy gained additional insights in the potential contribution of their Romanian sister company and business opportunities in Romania (both were less than expected). The water company was positive about its collaboration with the regional water company and therefore became willing to develop a long-term partnership.

At the Romanian side, all actors had a clear interest to learn from the Dutch team. Especially participants from the municipality and the water company of Tecuci hoped that the project would form a basis for concrete improvements in their water system. As a result the interactive process, these organizations became both motivated to intensify their 
collaboration with each other. Unlike the other Romanian organizations, they also expected to benefit from the water partnership. The interactive process was motivating for all Romanian actors, even though the project had no tangible benefits and took longer than expected. Since the project provided them with new solutions, insights and perspectives, they were very interested to further collaborate with the Dutch team. Thus, learning - at the individual and collective level - changed the motivations of actors involved but did not result in a goal that was supported by all participating actors.

\section{Cognitions and negotiated knowledge}

The Dutch water board initiated the project for the purpose of reducing flood problems but soon decided to also integrate the solving of water services problems. Although actors had diverse opinions of what was most important (solving of flood risk problems, improvement of water services or improved collaboration), they all agreed upon the integrated and participatory approach. For the Dutch team, the integration of various water domains was an obvious choice given the interrelations between both sectors. Moreover, it was seen as a means to bring various actors together and to increase fundraising opportunities. Romanian actors initially perceived the integrated approach as an important, innovative and interesting aspect of the project. The project experiences changed and diversified their opinions. Some argued that the approach was of added value, since the formation of integrated teams brought various actors together. Others argued that the approach was never implemented or that it had been an obstacle in the development of plans and solutions. Despite these diverse cognitions, both teams agreed to abandon the development of an integrated master plan. Furthermore, both teams developed an agreed upon list of measures. Both outcomes resulted from learning about the Romanian policy network, the potential of the adopted approach, the problems in the area (mostly Dutch experts) and potential solutions (mostly Romanian experts). Although actors created an agreed upon list of measures, they had diverse opinion about what should be done next. While the Romanian team suggested developing an integrated action plan for seven measures, the Dutch team decided, in consultation with two regional Romanian actors (not part of the project team), to focus on the further development of two.

The project was implemented using a participatory approach. Local authorities and stakeholders would be actively involved, among others, through the application of an interactive design method. After discussing the projects' approach with local and regional actors, the Dutch team suggested to form a local team and a consultative committee. In the opinion of most actors, the consultative committee did not function well. However, actors had different opinions about whether the project was too much local-oriented and about whether earlier and closer involvement of national actors would have made a difference. As regards the interactive design method, most actors had no experience with the method until its small-scale test application in visit 1. The experience made Dutch actors aware that the method helps to energize participants but also made some actors doubt the added value of 
the method in solving problems without a clear spatial component like water services problems. The Romanian team valued the method and some of them also used it later in dealing with a multi-actor problem. New insights in the method and the Romanian policy network made the Dutch team decide to cancel the methods' application in Romania (this decision followed the postponement of the application due to air traffic problems), which was regretted by the Romanian team. Thus, actors learnt at the collective level but did not arrive at shared understandings how to deal with or prioritize problems.

\section{Resources and pooling of resources}

Financial resources for the project itself were provided by Dutch actors. In order to mobilize the necessary institutional and financial support for follow-up actions, a consultative committee was established. Committee meetings were attended by regional and local authorities but - despite the efforts of the Romanian team - not by national authorities. Towards the end of the project, the Dutch team also directly contacted regional and national authorities to mobilize support, which was without success. The teams eventually concluded that it was nearly impossible to mobilize regional or national support for local measures that were not prioritized in existing master plans.

Human resources and knowledge were contributed by the members of both project teams. Each of the Dutch organizations was represented by one or several experts who had complementary expertise and participated to various extents in missions. The relatively large number of organizations enabled the pooling of resources but probably also made it more difficult to keep each other informed and to reach an agreement. What complicated the collaboration was that the project leader was the only Dutch actor with relevant experience in Romania (not in water projects) but could not attend a crucial mission (mission 1). Furthermore, the division of tasks among Dutch experts raised discussion. Only DLG was paid for its involvement and therefore expected to execute most of the actual work (e.g. writing of the project proposal, leading and managing the project, chairing minutes and preparing meetings and minutes). However, DLG experts lacked organizational and financial support to execute all these tasks in a satisfactory manner. Most Dutch actors concluded that their actual contribution was more related to the process (e.g. energizing and connecting people) than to the content. They were disappointed about the actual use and impact of their resources but highlighted that the project had been a great learning experience that increased their capacity to implement national and international projects. Furthermore, two Dutch organizations decided to pool their resources with the regional water company in a water partnership. This outcome was a direct result of their interactions in the periphery of the project.

The Romanian team was expected to contribute knowledge about existing problems and the policy network. All members were actively involved and contributed information about the problems and plans that were relevant to their own organization. The technical assistant and 
project secretary collected, translated and communicated this information to the Dutch team. This was not very effective, since the Dutch team had difficulties to understand and value the provided information. Working groups with members of both teams were further established to enhance the creation of a knowledge base but people in these groups never started to really interact with each other. One of the bottlenecks was that the local team appeared to have little insight in the meaning of on-going policy developments for the project and project area. Relevant information on this aspect became available rather late and was mostly provided by external Romanian consultants. From that moment on, the project focus shifted to the creation of support for measures that had local priority but were not included in existing master plans. The above shows that the pooling of resources was not without problems and that actors were unable to mobilize the resources that were needed to solve any of the local problems in the project area. However, the project did result in an increase of knowledge, insights and skills and led to the pooling of resources for a partnership that involved some of the participating organizations.

\section{Relations and trust}

Before the project started, most Dutch actors involved were familiar with the other organizations but had no direct relational experiences with the other actors. One of the reasons to start a joint project was to develop mutual relations between organizations with diverse interests and between interdependent public organizations. While some members of the team did not get along very well, most of the actors developed good personal relations that potentially enhance and ease future collaboration. Also Romanian actors were familiar with each other but did not collaborate before. Although it was not natural for the members of the Romanian team to collaborate, they all had very positive relational experiences and emphasized the involvement, commitment and enthusiasm of other actors. Many of the non-local actors were not yet familiar with each other and with the local actors. The development of relations between and across various governance levels was mentioned as an added value of the project that would ease future problem-solving. Interaction thus contributed to the development of relational qualities that support future collaboration in the Netherlands and in Romania.

Most actors involved had very little experience with international water projects. During the project, most members of the project teams also had little direct and personal interaction. Language barriers played a role in this: the members of the Romanian team had limited knowledge of English, which meant that there was usually a need for translation, limiting the direct interaction between actors of both teams. Outside international visits, informal and formal communication mostly went via the project leader and the project secretary who had very positive relational experiences. As regards the overall collaboration, the Romanian team valued their collaboration with and the commitment and expertise of the Dutch team and was interested in future collaboration. As explained before, the Dutch team expected their counterparts to be more proactive and had the impression that information was 
withheld. As a result of these negative experiences, they became less willing to collaborate. What also played a role in this was that the Dutch team learnt about the policy network and realized that it would be more productive to collaborate with regional actors who speak English and have more power to get things done.

\subsection{Discussion: Learning as a basis for further collaboration?}

To understand the nature of effects of learning, we examined a collaborative process through which various Dutch and Romanian organizations aimed to solve water problems. The actors who represented these organizations had diverse motivations, cognitions and resources and were not used to collaborate with each other. The interactive process promoted diverse learning processes. In the substantive domain, Dutch actors gained new knowledge and insights in existing problems and learnt how to approach and implement projects in an international setting. In the relational domain, they learnt about the perspectives and capacity of other actors. Some of them also developed relations that could support future collaboration. Romanian actors learnt in the substantive domain about potential solutions and how to deal with multi-actor problems. In the relational domain, they learnt about their own position in the policy network, perspectives of other Romanian actors, developed relations that could support future collaboration among local actors and with Dutch actors. Thus, the case confirms that interactive settings enable learning in the substantive and relational domain. Social learning sometimes remains at the individual level, changing only change the characteristics of individual actors, whereas other learning processes contribute to collective outcomes. In addition, the case confirms the finding from previous research that external and local actors who participate in the same process tend to learn about different aspects and topics (Rist, et al., 2006).

In the case, the learning by external actors had very different outcomes than the learning by local actors. The Dutch actors had different opinions about the process course and outcomes but all became aware that the adopted approach had not been successful and that their collaboration with the local team - and sometimes also with each other - had been difficult. They had the intention to develop a long-term collaboration but decided not to continue their collaboration with local actors. A probable explanation is the relatively short duration of the relation with their counterparts. In such relations, actors have little faith in each other implying that unmet expectations tend to lead to termination (Rousseau, et al., 1998). However, this does not explain why the Romanian team - for whom the project was also less effective than hoped for - was still interested in any form of future collaboration. A factor that explains this difference is self-effectiveness assessment, one of the sources of motivation. When an actor perceives that preferred performance is beyond its capacity, a demotivating effect can occur (De Boer \& Bressers, 2011). The latter applies to most members of the Dutch team. They became involved believing that they could contribute something to the process but learnt that their preferred performance was beyond the resources of themselves and their counterparts. As the Romanian team was more awaiting 
and looking for ways to increase their skills, the process did not have a demotivating effect on them.

In the case project, actors learnt in interaction with each other, but it was not the type of learning that creates a common basis on which collaborative follow-up actions can be based. The case actually demonstrates that social learning may positively and also negatively influence further collaboration. This confirms previous research findings about the nature of social learning, which are seldom emphasized in the scholarly literature, namely that interactions may promote constructive and destructive social learning. Constructive learning is reflected in converging actor networks and ways of thinking. In addition, learning can also have the opposite effect, drifting actors further apart and complicating future collaboration (Vreugdenhil, 2010). In other words, interactions may produce or confirm negative perceptions of other actors, deepen differences in views or worsen relationships (Muro \& Jeffrey, 2008; Schusler, et al., 2003). The case further demonstrates that a single project consists of multiple collaborative settings in which actors learn. Firstly, the case project resulted from a constructive learning process: both teams developed a joint basis and started pooling resources to implement the project. Secondly, both Dutch and Romanian actors had constructive interaction with members of their own team. Thirdly, the interactions between Dutch and Romanian actors were constructive from a Romanian perspective and predominantly destructive from a Dutch perspective, with the exception that interactions in the periphery of the project formed the basis for a partnership between two Dutch actors and one regional Romanian actor. Regarding the overall process, the learning of Dutch experts was decisive, since they possessed - in contrast to their local Romanian counterparts - the resources to continue the collaboration and could therefore also decide to discontinue their collaboration. Thus, learning influences further collaboration not only through what actors learn but also who learns. Whose learning has most impact depends on how resources are distributed among actors. Learning does not change the power balance between actors but may influence the mobilization of resources by increasing the capacity of actors. Further collaboration between the actors involved is not to be expected but also not completely ruled out. For example, local Romanian actors may be successful in mobilizing resources for another project and decide to approach Dutch experts again. When such a new project would be organized differently, Dutch actors may decide to participate despite their relational experiences in this project (Rousseau, et al., 1998).

\subsection{Conclusion}

In this chapter, we analysed the nature and effects of social learning and how this may contribute to further collaboration. Insights from social learning and policy implementation literature were integrated into a conceptual model, which describes how social learning impacts the motivations, cognitions and resources of actors in collaborative settings. In this conceptual model, we made a distinction between two types of social learning - substantive 
and relational learning - that occur at the individual and the collective level. We asserted that learning contributes to the development of collective outcomes on which actors can base further collaboration for the solving of an environmental problem. These collective outcomes include a motivating goal, negotiated knowledge, pooling of resources and trust (associated with positive relational experiences). We used these insights in a case study, which concerned an international water project that was implemented in collaboration between Dutch and Romanian actors. While most literature focuses on the constructive aspects of learning (i.e. social learning enables collaborative actions), the case study demonstrates that learning can also be - partly - destructive. In the case, external and local actors learnt about different things in multiple settings. The interactions within both teams and between some of the actors in the periphery of the project were both examples of constructive learning. However, the learning that had most impact on further collaboration was the destructive learning of the external - and more resourceful - actors. The external actors had negative relational experiences and learnt that the intended actions were beyond the capacity of the actors involved. Hence, they decided not to continue the collaboration implying that no collaborative actions are planned to solve water problems in the project region. The case study thus confirms the importance of substantive and relational learning in collaborative settings, and draws attention to the destructive nature learning can have. We conclude that social learning may contribute to collective outcomes and therefore form a pathway for further collaboration but can also have the opposite effect. These findings are based on the experiences of an international water project but equally relevant to collaborations that are organized around the solving of an environmental problem. Thus, to understand the effects of learning in collaborative settings, it is crucial to understand not only how much actors learn through their multiple and diverse interactions, but also what is learnt and whose learning has most impact. 


\section{Chapter 6}

\section{The influence of contextual factors on the case studies}

This chapter is based on: Vinke-de Kruijf, J., Teodosiu, C., Bressers, H. T. A., \& Augustijn, D. C. M. (2013). How contextual factors influence the effectiveness of international projects: the case of Dutch-funded flood risk management projects in Romania (pp. 57-75). In C. De Boer, J. Vinke-de Kruijf, G. Ozerol \& H. Bressers (Eds.), Water Governance, Policy and Knowledge Transfer: International Studies on Contextual Water Management Oxford: Earthscan, Routledge Books, Taylor \& Francis Group. An earlier version of this chapter was presented at the IGS-SENSE conference on 'Resilient Societies: Governing Risk and Vulnerability for Water, Energy and Climate Change' that was organized at the University of Twente between 19 and 21 October 2011.

\subsection{Introduction}

River floods are one of the most threatening natural risks and have many negative consequences for humans and human society (Samuels, et al., 2006). Also in Europe, floods have been increasing and are currently the most common natural disaster (EEA, 2008). International organizations expect that the frequency and intensity of floods will only grow further due to climate change and the increase of population and economic activities in flood prone areas (WMO, 2009). Within this context, international efforts aiming at flood risk reduction are growing. An example of such effort is the Associated Programme on Flood Management that promotes the concept of Integrated Flood Management and supports the implementation of actions that follow this principle (APFM, 2012). In a European context, best practices on flood management were recently translated into a framework directive for the assessment and management of floods (European Directive 2007/60/EC). While floods are common problems, floods have diverse causes and countries also have different capacities to deal with them (Van Alphen \& Lodder, 2006). Moreover, universal remedies or blueprints for effective water management do not exist. This means that any international transfer of knowledge should be done with care and only after careful consideration of the context-specific conditions and circumstances in which knowledge was developed. While many scholars acknowledge the importance of context in water management, little is known about how contextual factors inhibit or promote knowledge transfer. This chapter aims to address this research gap by asking: How do contextual 
factors influence the effectiveness of water projects that involve international knowledge transfer?

In this chapter, knowledge transfer projects are defined as interactive processes in which actors of two or more different countries share and acquire knowledge for the purpose of using it for case-specific objectives (Vinke-de Kruijf et al., 2011). This definition emphasizes that an effective knowledge transfer includes the application of knowledge. In this sense, knowledge transfers are very similar to policy implementation processes. We therefore assume that the course and outcomes of knowledge transfer projects can be understood using the Contextual Interaction Theory (see Chapter 1). Empirically, this chapter builds upon the experiences of three projects that involved the transfer of knowledge about flood risk management from the Netherlands to Romania and were implemented with financial support of the Dutch government. This implies that the projects under study are examples of transfers that are driven by the proactive attitude of a transferring country to export its knowledge (Stone, 1999). We therefore choose to assess the effectiveness of these projects from a Dutch policy perspective and define effectiveness as the extent to which a project contributes to the solving of flood-related problems in Romania and generates follow-up projects for the Dutch water sector (see Chapter 3).

The structure of the chapter is as follows. First, we introduce our main theoretical concepts and case study methodology. We than introduce the projects (including the context) of the case studies. Subsequently, we describe the motivations, cognitions and resources in relation to these projects. Following this analysis of actor characteristics, we analyse and discuss the influence of contextual factors on the cases. The last section presents our conclusion about how contextual factors influence the effectiveness of international knowledge transfer projects.

\subsection{Theoretical concepts and methodology}

\section{Contextual Interaction Theory as conceptual framework}

As explained in the introduction, knowledge transfer projects are in this chapter conceptualized as policy implementation processes. Inspired by the Contextual Interaction Theory, we assert that such processes are shaped by the characteristics, i.e. the motivations, cognitions and resources, of the actors involved. Therefore, the following questions are central in our analysis: What are the substantive or procedural reasons (motivations) of actors for being involved and taking certain actions? What are the perceptions (cognitions) of actors about the relevance of the project, the urgency, nature and meaning of the problem at stake and potential solutions? What is the capacity of actors to act (financial resources, human resources and knowledge) and power to get things done (institutional resources)? (Bressers \& Kuks, 2004; Owens, 2008; Vinke-de Kruijf, 2011b). In an interactive process, actor characteristics are in dynamic interaction with each other and tend to change. These 
changes can form a basis to attain ultimate outcomes (problem-solving and follow-up projects in this case). According to Chapter 3, the likelihood of realizing ultimate outcomes especially depends on the development of a joint motivating goal, the creation of a negotiated knowledge base (i.e. knowledge that is agreed upon and valid) and the mobilization of necessary resources (by pooling them if necessary). In addition, positive relational experiences increase mutual trust and therefore improve the chances on future cooperation, but are not analysed in this chapter.

While the course and outcomes of an actor-interaction process result from the dynamic interaction between actor characteristics, they are also embedded in wider, structural and project-specific contexts (see Chapter 1). Although we acknowledge that contextual factors only influence a knowledge transfer process insofar as they change characteristics of actors involved, we consider an analysis of contextual conditions, circumstances and differences to be beneficial, since such an analysis helps to understand why actors possess or develop certain characteristics. Literature shows, for example, that transfers tend to be easier between countries that are similar in terms of resources (Rose, 1993). A comparative analysis highlights that participatory approaches in water management are more effective in some countries than in others due to institutional factors (Mostert et al., 2007). Another study shows that actors tend to implement proposed reforms that are socially acceptable or economically attractive while neglecting reforms that are incompatible (Sehring, 2009). These examples show that transfers are influenced by cultural, institutional and historical configurations (Rose, 1993). While research shows that context influences policy transfers, contextual factors do not necessarily determine the success of a transfer. Comparative research shows, among others, that contextual similarity is not correlated with the effectiveness of a transfer, but rather depends on whether transfers are supported by actors who are pulling in, i.e. whether powerful actors are convinced that the transfer is useful and have a strong desire to change things (Kroesen et al., 2007). This chapter discusses two ways in which contextual factors are likely to influence the effectiveness of a knowledge transfer process. Firstly, actors of the transferring country have another contextual background and thus different characteristics than actors of the receiving country. Secondly, the interactive process and the knowledge being transferred need to be embedded in the wider and structural context of the receiving country.

\section{Case study methodology}

This chapter builds upon qualitative case study research as its research methodology. By doing so, we aimed to describe and to understand the projects under study within their relevant contexts. This improved understanding is provided by analysing and comparing multiple projects that are embedded in a similar context (Yin, 2009). In this chapter, we compare three Romanian projects: the development of an Integrated Area Plan to create 'Room for the River' (case A); the implementation of a Flood Information and Warning System (case B); and the development of a Master Plan for Integrated Water Management 
(case C). All projects were implemented in collaboration between Dutch and Romanian actors in the period between 2008 and 2011 (see Figure 6.1 for the location of the cases). In this period, the first author was based in Romania and collected data by means of direct observation, interviews and document analysis. She observed all major project activities (i.e. plenary meetings, workshops and field visits) and some of the project team meetings yet had no formal role in the design or implementation of the projects. To increase the reliability of her observations, she often cooperated with a Romanian co-observer and discussed the observations with project team members. She also regularly conducted informal interviews with project participants. After each project was completed, she conducted semi-structured interviews with the main project team members. The observational and interview data were complemented with written data that were retrieved, for example, from project reports, policy documents, websites and newspapers. For each project, a 'thick' description was prepared and published in the form of a case study report. These reports present detailed narratives of the project context, the interactive process and the characteristics of actors involved (Vinke-de Kruijf, 2011a, 2011b, 2012). The case studies were complemented with an analysis of Romania's wider and structural context. For this, the first author analysed relevant documents (including literature, newspaper articles, legislation and policies), participated in meetings, interviewed policy makers and experts and distributed a questionnaire among operational flood risk managers.

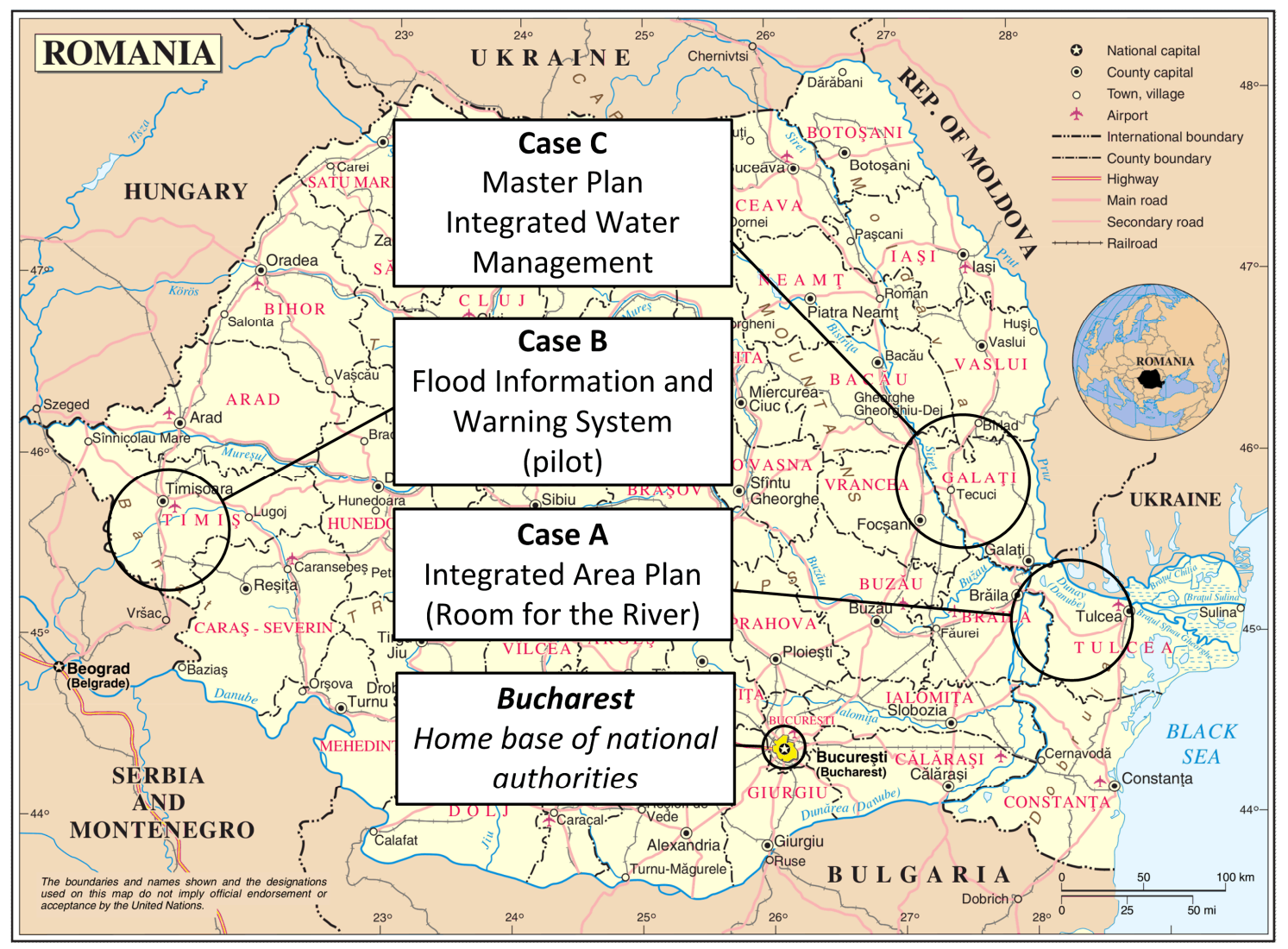

Figure 6.1 - Map of Romania with the location of the three cases (background map from United Nations, 2008) 


\subsection{Dutch-funded flood risk management projects in Romania: context and case studies}

\section{Dutch-Romanian cooperation setting}

The Netherlands has a long history in water management. Within this context, it has long been active in supporting the solving of water management problems around the world. In its National Water Plan of 2009-2015, the Dutch government mentions two major reasons for supporting water projects around the world. Firstly, it supports contributions to solving water-related problems (especially mitigation of climate change and realization of the Millennium Development Goal on water and environment). Secondly, it aims to strengthen the international position of the Dutch water sector by supporting collaborative projects with potential spin-offs in the form of follow-up projects. These objectives are especially realized through the exchange of knowledge and experiences (Min. V\&W, 2009). It is within this context that the presented cases received the financial support of the Dutch government. Cases A and B were financially supported by Partners for Water, a programme that aims to stimulate the implementation of innovative projects of the Dutch water sector abroad. Case $\mathrm{C}$ received financial support from a foundation that supports international projects of Dutch water boards.

The collaboration between the Netherlands and Romania on water and environment dates back to 1995 when the Environmental Ministries of both countries signed a Memorandum of Understanding. The number of Dutch-funded projects increased substantially after 1998 when both countries signed a bilateral agreement. This agreement formed the basis for the implementation of various Dutch-funded projects in Romania. Between 1995 and 2007, about 140 projects in the field of environment and water (costing over 20 million Euros) were implemented with financial support from programmes like the Social Transformation Programme Matra and the Emerging Markets Cooperation Programme PSO/PSOM.

In 2007, Romania became a member state of the European Union (EU). At this time, the Netherlands began to phase out its bilateral assistance. Although the number of Dutch programmes that support projects in Romania decreased, various funding agencies continue to provide financial support. Furthermore, bilateral contacts between both countries continue to exist. In 2009, the Dutch Union of water boards and the National Administration for Romanian Waters signed a Memorandum of Understanding (RNE \& EVD, 2009). Through this collaboration, the Dutch water boards intend to exchange knowledge with Romanian water authorities (Unie van Waterschappen, 2005). In 2008, the Netherlands Water Partnership established a Romania platform that aims to strengthen the position of the Dutch water sector in this country. This platform was established since Romania is expected to become an attractive market: huge investments are needed to bring environmental infrastructure in line with EU standards but domestic capacity and expertise is limited (Van Peppen, 2008). In the past years, the platform organized a wide range of 
activities to promote Dutch-Romanian cooperation in the water management domain. The platform also initiated in collaboration with the Union of water boards a Dutch-Romanian panel with high executives and civil servants in 2009. This panel meets regularly to discuss various water management challenges that relate to living in a delta area (e.g. flood risk management, water quality and international river basin management). Completed and potential collaborative projects in the flood risk management domain, such as the presented cases, are also discussed in this panel.

\section{Case A: 'Room for the River' and People in Cat's bend region}

The objective of case A was to develop, in close cooperation with relevant stakeholders, an integrated plan that would contribute to flood risk reduction for the Cat's Bend region. This region is located just upstream of the Danube Delta where two major rivers (the Prut and the Siret) join the Danube river. The project was initiated in 2006 and implemented between September 2008 and December 2009. The project design was inspired by the Dutch 'Room for the River' concept, which involves the integration of safety with other functions (e.g. nature and socio-economic development) and a preference for measures that create more space for the river rather than traditional measures, such as the further heightening of dikes. The project was also based on a Romanian study on the re-assessment of the Danube floodplains. For the Cats' Bend region, this study recommended combining water storage with agriculture. The project involved a wide range of stakeholders including representatives of local and regional authorities, governmental and non-governmental organizations, and the private sector. This participatory process was supported by a team of two Dutch and four Romanian organizations. The team interviewed and invited stakeholders, prepared maps, visualized and conceptualized ideas, developed project materials, modelled the water system and calculated the impact of measures on the water level. The project resulted in three design concepts that could contribute to flood risk reduction along the Danube. The knowledge that was transferred and generated in the project was not used in any follow-up actions. The formal commissioner of the project, the Ministry of Environment, did not pay attention to the project results. Local and regional stakeholders wanted to implement some of the outcomes but were lacking necessary resources. As the project did not contribute to problem-solving or follow-up projects, it has not been effective from the perspective of the Dutch financers (Vinke-de Kruijf, 2011b).

\section{Case B: Implementation of FLIWAS in Banat region}

Case B aimed to support Romanian water authorities through the pilot implementation of a Flood Information and Warning System (FLIWAS). FLIWAS is an internet-based application that helps to manage flood-related information before, during and after high water events. The application was recently developed in a European project and is currently being used by Dutch and German partners for the Rhine River basin. The pilot project in Romania was initiated in April 2009 and implemented between September 2009 and April 
2010. The project was executed in cooperation between two Dutch consultants and four Romanian organizations. The pilot included the development of a Romanian FLIWAS environment (including the installation of an internet server and the training of potential users and administrators), the pilot implementation of FLIWAS at a regional water authority and various communication and dissemination activities. During the project, there were regular meetings with a wide range of actors and various work sessions at the regional water authority. Installing the FLIWAS on a national server constituted a major issue during the implementation process. Various experts had difficulties arriving at a mutual understanding. As a result, the server was installed much later than expected. To prevent further delay of the project, collected data were initially inserted on a Dutch server. The plan was to transfer these data to the Romanian server but it was unclear who was able and willing to do this transfer. In the end, data were never transferred and the regional authority did not begin using FLIWAS. The project therefore did not directly contribute to the reduction of flood risks. The project may still become effective as the Ministry of Environment was very interested in applying FLIWAS at a larger scale and also included the further development and implementation of a system like FLIWAS into a project proposal for the implementation of the European Strategy for the Danube River basin (Vinke-de Kruijf, 2011a).

\section{Case C: Integrated Water Management in Tecucel River basin}

The third case study concerns a project that was initiated by a Dutch regional water board following floods along the Tecucel River in 2007. The project aimed to develop an integrated framework (master plan) for the management of flood risks, drinking water and wastewater that would include several "no-regret measures" (i.e. easily implemented measures that improve the water system). The project was implemented in cooperation between six Dutch organizations (including a water board, water company, municipality, governmental agency and two private companies) and five Romanian organizations (including three municipalities, a local water company and a local person of a regional water authority). Dutch ideas on interactive planning, which meant to enhance collaboration between various actors, provided the inspiration for the project. The project included visits by the Dutch team to Romania and also a visit each by the Romanian team and a regional water company to the Netherlands. While analysing the problems, potential solutions and on-going policy developments, the project team realized that regional authorities already drafted master plans, one for drinking water and wastewater and one for flood risk management. This led the teams to the conclusion that another master plan would be redundant. The Dutch team therefore decided to focus on the formulation and further development of two no-regret measures (i.e. a separate system for sanitary sewage and storm water runoff for the City of Tecuci and a flood retention reservoir along the Tecucel River). As these measures did not have any regional or national priority, the teams were not able to mobilize the necessary support and funds to further develop these measures. 
However, the project did form a basis for a formal agreement, a Water Partnership, between the Dutch water board and water company and the Romanian regional water company, which acquired the local water company during the project course. This partnership will form the basis for further exchange of knowledge and experiences with drinking water and wastewater management for the next three years. The project itself was not effective: it did not contribute to problem-solving; neither did it generate any follow-up projects that would benefit the Dutch water sector (Vinke-de Kruijf, 2012).

\subsection{Case study results: characteristics of actors involved}

\section{Motivations and the development of a joint motivating goal}

In all cases, most actors were motivated by the international dimension of the project; they simply enjoyed participating in an international project. The opportunity to transfer knowledge was another common source of motivation. Dutch experts are formally interested both in sharing and acquiring knowledge, that is, learning from the experiences of other countries (Min. V\&W, 2009). However, the cases show that Dutch experts were especially interested in sharing their knowledge: they believed that their knowledge could contribute to the solving of water-related problems. For some actors, knowledge sharing was important not only from a personal but also from their organizational perspective. This especially applies to the water board and the water company that participated in case C. Together with other water boards and water companies, they committed themselves to the realization of the Millennium Development Goals. Another motivation for sharing knowledge was that it provided experts with the opportunity to further develop and test their existing knowledge. An expert in case A mentioned that international projects are very useful training for landscape architects as they have to apply their skills in an unknown setting. Experts in case B were eager to test whether the FLIWAS technology was applicable in another setting. For the private organizations involved, the increased chance of being involved in other international projects played an important role. Experts mentioned that their company participated in the project to strengthen their international network, position and portfolio.

A major motivation of the Romanian actors was to reduce water-related problems in the region under concern. Most of them highly valued Dutch knowledge and believed that the project could contribute to solving certain issues. They were therefore interested in acquiring Dutch knowledge concerning the application of a certain method, concept or technology or about potential solutions to concrete problems. They further expected that the international dimension of the project would help to raise national attention for local issues (local actors in case $\mathrm{C}$ ) or would make them known as being forerunners (regional authority in case B). At the same time, actors in case A initially doubted whether their ideas would form the basis for the project outcomes and whether these outcomes would influence the decision-making process. Some of them were also sceptical about the role of Dutch experts 
and the added value of their expertise. When they witnessed that their ideas were taken into account, they also started to support the implementation of the project objectives. Like the regional and/or local actors in the other case studies, they eventually also saw the project as an opportunity to influence decision-making. However, despite the objectives of all cases being (eventually) strongly supported by local and/or regional actors, they were often not implemented. One of the main issues was that the project goals were lacking support at the national level. Cases A and B were both initiated, and thus initially supported, by actors at the national level. In case A, this support diminished especially after the State Secretary was replaced. The Ministry of Environment eventually ignored the results and the request of local authorities to support them with the implementation of results. In case $\mathrm{B}$, the Ministry stayed involved and was also motivated to include an application like FLIWAS in a new project proposal. Case $\mathrm{C}$ was designed in a bottom-up fashion where the Ministry was asked to have a consultative role. Although local and regional actors were keen to involve the Ministry, they were never able to raise sufficient support to further elaborate the project results.

In all cases, the motivations of some of the actors involved also changed during the course of the interactive process. Although Dutch experts in all cases remained committed to finalizing the project, several experts became less motivated to continue the collaboration. Experts of a Dutch governmental agency (involved in cases A and C) explained that their organization was formally committed to international water management but that they discovered that the actual organizational support for such projects was limited. This lacking support is among the reasons why they became less motivated to continue working on such projects. The collaboration with Romanian partners was also often not as expected. In case A, several experts were disappointed about the expertise that was contributed by one of the Romanian partners and therefore reluctant to collaborate with them in future projects. In cases $\mathrm{A}$ and $\mathrm{C}$, experts had doubts whether some of their Romanian partners were actually willing to make an effort to solve their water problems. This is why experts in case A left the initiative for follow-up with the Romanian actors.

\section{Cognitions and the creation of 'negotiated knowledge'}

All cases were based on the recognition that the frequency and intensity of floods are increasing and that the reduction of flood risks and related issues forms a pressing issue. This cognition formed the main input for the project proposals that were prepared by Dutch experts following discussions with Romanian actors but this cognition often changed during the interactive process. Especially in case A, the initial framing of the project by Dutch experts did not correspond with the actual problems in the area. Dutch experts expected that floods were a major problem in the region. However, when the project started, it soon appeared that Romanian partners and stakeholders did not share this cognition. In the opinion of the Romanians, the main problems in the area were of a different nature and included unequal access to resources, drought, declining biodiversity 
and a lack of public participation. Dutch experts therefore decided to broaden the project scope. The developed plans were still largely as initially expected by the Dutch experts involved. They created more 'Room for the River' and therefore contributed to flood risk reduction but also to regional economic development and a better micro-climate. In case $\mathrm{B}$, floods were also perceived as being an important issue by the Romanian partners. In this case, some of the Dutch experts also discovered - although to a lesser extent - that the actual problems were different than expected. A Dutch expert explained, for example, that he only realized during the project that FLIWAS could really reduce the vulnerability of the emergency management system that resulted from an overdependence on individuals and individual knowledge. Case $\mathrm{C}$ was also initiated in order to reduce flood risks but the scope of the project was broadened already from the beginning to also include problems in the water services sector. Only after the project started, the Dutch experts discovered that relevant actors did not know each other yet. In the opinion of Dutch experts, one of the main project results was therefore that the project created a connection between these actors.

All three cases concerned the transfer of 'Dutch ideas' to Romania. As these ideas had not been implemented in Romania before, both Dutch and Romanian actors were uncertain whether these ideas could be successfully applied in the Romanian context. While case A was not very effective, most of the actors involved were very positive about the applicability of the concept and method used. Case B proved to Dutch experts that FLIWAS could be implemented in Romania. Romanian experts only partly shared this cognition. They doubted whether it could be implemented in other parts of Romania and as they never began to use FLIWAS - also doubted its actual usability. The integrated and bottom-up approach in case $\mathrm{C}$ appeared to be rather ineffective. Dutch experts concluded that the integrated approach was of added value but it should be reconsidered and that a better balance was needed between bottom-up and top-down. However, several Romanian experts had doubts about whether such an approach could ever be effective in Romania.

\section{Resources and the mobilization of necessary resources}

In all cases, Dutch actors provided most of the financial resources for project implementation. The costs of the projects were partly covered by a Dutch funding agency (about $80 \%$ in the cases $\mathrm{A}$ and $\mathrm{B}$ and about $50 \%$ in case $\mathrm{C}$ ) while the remaining costs were paid for by the Dutch organizations. Human resources were contributed both by Dutch and Romanian organizations involved. In case A, Dutch organizations paid for the involvement of Romanian partners and covered other costs (such as, meals and meeting locations). In the cases B and C, Dutch experts collaborated more closely with Romanian authorities who could often arrange such resources for free. One of the critical issues in all cases was the financing of follow-up steps. All cases predominantly involved local and regional actors (e.g. representatives of governmental authorities, non-governmental organizations or other stakeholders). However, follow-up actions for the cases usually required considerable 
investments that were beyond the capacity of these actors. In cases $\mathrm{A}$ and $\mathrm{C}$, actors from the area were motivated to continue with the project results but lacked the capacity to mobilize the resources for this. In case B, the Ministry was more closely involved and was in the position to integrate a tool such as FLIWAS into a proposal for external funds.

Since all cases concerned the transfer of a 'Dutch idea' (e.g. 'Room for the River', 'Sketch Match', FLIWAS or integrated water management) from the Netherlands to Romania, Dutch actors were important sources of knowledge. Projects were usually driven by general knowledge and initiatives of the Dutch experts involved as Romanian actors lacked the expertise to apply these ideas. In this sense, the knowledge transfers took place in a typical development setting in which local knowledge meets general knowledge of external experts (Rist, et al., 2006). In all cases, a Dutch expert was responsible for the overall project management. In addition, Dutch experts often made an analysis of which actors or stakeholders should be involved as Romanian actors were not familiar with the key concept, method or technology being transferred. Especially in case B, Dutch experts could also contribute some context-specific knowledge as they had been involved in DutchRomanian projects before. Romanian actors were important sources of context-specific knowledge and often responsible for the organizational aspects, such as, inviting stakeholders and arranging meeting locations. To manage the involvement of Romanian actors, each project had a Romanian project coordinator (and a Romanian project secretary in the cases B and C). In case A, experts had a facilitative role and the results were mostly based on context-specific knowledge that was provided by stakeholders. Also in the other cases, there was attention for the inclusion of stakeholder knowledge but, in practice, professional experts provided the most knowledge.

Romanian experts were generally valued for their high level of technical knowledge but their knowledge contribution was on several occasions less than expected by Dutch experts. In case A, Dutch experts expected that the participating institute would really contribute to the project content (e.g. hydraulic modelling, processing of geographic information and preparing area maps). Only during the project, it appeared that the institute could not provide such expertise. This was one of the reasons why the project outcomes were slightly different than expected. It also caused some experts to have reservations about working with the same institute in any future project. Experts in case B had similar experiences. In this case, the installation of the server was expected to be rather straightforward. Only during the project did it appear that the appointed expert did not have specific experiences in this domain. In case $\mathrm{C}$, one of the main misunderstandings between Dutch and Romanian experts was the need and availability of a master plan. Dutch experts only realized halfway through the project that a master plan was redundant as two regional master plans had just been approved. This shows that in all cases, Dutch experts attributed more knowledge to Romanian experts than they could contribute. 


\subsection{Analysis and discussion: on the role of contextual factors}

\section{The influence of differing wider contexts}

The previous section shows that in all cases there were major differences between Dutch versus Romanian actors in terms of motivations, cognitions and resources. In general, Dutch experts wanted to share knowledge and provided most knowledge and financial resources. Romanian actors participated in order to learn and acquire knowledge and to gain (financial and organizational) assistance with problem-solving. The country-specific background of both actor groups explains these differences. In terms of problem context, the Netherlands is a densely populated country with low-lying polders in which floods are extremely dangerous. In practice, floods rarely occur as the country adopted very high safety standards (Van Alphen \& Lodder, 2006). In Romania, floods have become a yearly recurring issue during the last decades. They are not only causing major economic damages but also caused an average of 13 casualties per year between 1969 and 2006 (GoR, 2010). As the intensity and frequency of floods are on the increase, Romanian actors are eager to acquire fresh knowledge about how to solve these problems. Moreover, Romanian actors perceive the Netherlands as one of the most - if not the most - advanced countries in flood risk management.

In the last decades, both countries also went through very different political and economic developments. Shortly after the Second World War, the Netherlands became closely involved in the establishment of the EU whereas Romania was ruled by a communist regime. Since the 1990s, Romania engaged in a transition process that aims to bring the country's political and economic system in line with mainstream European systems (Gallagher, 2005). In economic terms, the gross domestic product of the Netherlands was among the five highest and Romania among the two lowest of all EU member states in the past years (Eurostat, 2012). Being a relatively rich and export-oriented country, international assistance has always had a rather high priority in the Netherlands. This has created the opportunity to pay for the transfer of knowledge to less developed countries. This financial support is attractive for Romania, which depends heavily on external funds for the implementation of any project. To gain access to funds is especially challenging for local and regional actors who are therefore eager to participate in any project. What also plays a role in this is Romania's wish to 'catch up' with other EU member states (Rose, 1993). In case C, for example, actors also perceived the project as a means to learn from another EU member how to apply for EU funds.

As both countries need to comply with the same EU rules and legislation, their structural context for water management is partly similar. However, there are also differences that form an incentive for knowledge transfer. Especially in case A, actors were very eager to learn about the application of the 'Room for the River' concept or the interactive design method as tools for integrated and participatory water management. The Netherlands is 
known for developing these ideas and has experimented with them for years (Mostert, 2006; van Ast, 1999), while such approaches are still very new in Romania. Especially nongovernmental organizations were very interested in such approaches, which are required by various European Directives (including the Flood Directive) but often poorly implemented (Teodosiu, 2007; Teodosiu, et al., 2003). Dutch actors perceive the sharing of their knowledge in these domains also as one of their tasks as a more experienced country.

Literature often emphasizes that contextual differences complicate policy transfers (Mossberger \& Wolman, 2003; Swainson \& de Loe, 2011). However, the case of the Netherlands and Romania shows that such differences are also an incentive for knowledge transfer and therefore an important source of motivation. However, the cases also show that contextual differences can challenge the effectiveness of such transfers as it implies that actors have different cognitions and resources. In case A, Dutch actors framed flood risks as an urgent problem that was rooted in a lack of space for the river. This cognition was not shared by many of the Romanian actors involved. Only after adjusting the project scope, they could arrive at a common goal. The differing problem contexts of both countries provide an explanation for these differing cognitions. While this difference did not affect the effectiveness of this project, differences in terms of structural context were influential. In the Netherlands, 'Room for the River' projects are part of a national programme (Min. V\&W, 2006). In Romania, such a programme did not exist and the measures were not sufficiently supported by national actors. As a result, it was not possible to mobilize financial resources for implementation. The effectiveness of case B was especially affected by differences in terms of knowledge resources, which led to problems with the installation of the server and had a negative impact on the effectiveness of the case. The underlying problem was that Dutch experts expected Romanian experts to contribute a slightly different type of technological knowledge than Romanian experts expected to be necessary. In case C, Dutch actors expected - on the basis of their own structural context - that Romanian actors were used to collaborating with each other. Later it appeared that in the Romanian structural context, there was very little interaction between actors with a role in water management. These differences explain why actors understood the meaning of existing master plans only when the project was already halfway complete.

\section{Embedding in the dynamic Romanian context}

Analysis of the cases shows that projects that involve the international transfer of knowledge are often less effective than planned. None of the projects contributed directly to the reduction of flood risks and only case B is most likely to create follow-up projects for the Dutch water sector. One of the main explanations for these differences is that in the cases $\mathrm{A}$ and $\mathrm{C}$, there were no powerful players 'pulling-in'. In other words, resourceful actors were not convinced about the need to implement or to elaborate the project results. In case A, a powerful actor (the State Secretary for Water) was involved in project preparations and supported the project idea. However, this national support faded when - 
following elections - this person was replaced. Also at the regional level, several key actors were replaced following elections. These political changes would not have had such a negative impact on the project if the 'Room for the River' concept would have been widely supported. This was not the case since the concept was rather controversial, which made it difficult to raise support for the project among executives and politicians. This was even more so as the project was finalized in the middle of another election period. A mismatch between the project results and the political context thus explains why resourceful actors would not support the project. What is remarkable is that the process was initially also not supported by regional/local actors. This related to a combination of contextual factors, such as, distrust in the government, negative experiences with participation and high dependence on the national government for resources. This negative motivation eventually altered and therefore had no negative impact on the projects' effectiveness.

Case B was implemented in a relatively short period, which is one of the reasons that it was not affected by any changes in the political context. What contributed to the effectiveness of this case was that powerful actors (at the national level) supported the project from the beginning until the end. Improvement of information and warning systems was one of their key priorities and they therefore deliberately looked for ways to integrate a tool like FLIWAS in one of their project proposals. This confirms that transfers are likely to be supported by policy makers - and thus more likely to be implemented - when they are consistent with political consensus (Rose, 1993). In this case, it was also less difficult than in the other cases to embed the project as the project involved several Dutch experts who were familiar with the Romanian context and policy network due to their extensive project experience in the country. However, whether the tool will eventually be used is still to be seen. Experts explained that its actual use may become problematic, among others, because automated measurement stations are not functioning well and end users lack access to modern information and communication means. In other words, they doubt whether the tool fits Romania's technological context.

In case $\mathrm{C}$, the entire project developed very differently than planned. One of the issues during the process was that none of the actors had an adequate insight in relevant policy processes. One of the underlying problems was that there is very little interaction between various Romanian actors with a role in water management. This confirms that incoherent governance may indeed affect project implementation as it leads, among others, to more uncertainty and a failing capacity to recognize win-win situations (De Boer \& Bressers, 2011). When information became available, the initial project objective - a master plan became redundant. However, there were also no project resources to develop a completely different project. Besides this, the project teams also failed to mobilize financial resources for the implementation of their common goal. This failure closely relates to the misfit between the Romanian situation and the integrated and bottom-up project approach. An integrated approach was difficult to realize since European and national funds are not organized in this way. The adoption of a bottom-up approach was also not effective. After 
the communist period, a decentralization process begun but developed in a rather inconsistent manner. While competences were transferred to a lower level, associated power and finances were not. The decentralization process also did not account for the lack of expertise and training of local officials (Bădescu et al., 2004). The funding programmes that were of interest in case $\mathrm{C}$ were only accessible for regional and national authorities. These actors had not been involved in the project and did not give priority to the problems in the area. What also did not help the mobilization of resources in the cases $\mathrm{A}$ and $\mathrm{C}$ was that national funds just decreased considerably as a result of the global economic crisis.

\subsection{Conclusions}

The aim of this chapter is to provide insight into how contextual factors influence the effectiveness of projects that involve an international knowledge transfer. We conceptualize these projects as actor-interaction processes that are embedded in wider, structural and specific contexts. The Contextual Interaction Theory shows that these contexts only exert an influence on such processes - and their effectiveness - via their influence on the motivations, cognitions and resources of actors involved. To better understand the influence of specific conditions and circumstances, we analysed three Dutch-funded projects that involved the transfer of knowledge about flood risk management from the Netherlands to Romania. Due to contextual differences, there were major differences between Dutch and Romanian actors in terms of motivations, cognitions and resources. These differences provide an incentive to collaborate and therefore an important source of motivation. They also imply that actors have different cognitions and resources, which can result in disagreement and misunderstanding. A further analysis of the projects' embedding into the Romanian context highlights that the effectiveness of the projects was correlated with the involvement and support of national actors. In other words, the cases confirm the importance of powerful players 'pulling in' (Kroesen, et al., 2007). Especially case C further reveals the fragmented governance setting of Romania as another factor that inhibited a successful knowledge transfer. This finding confirms the notion that fragmented governance may seriously hamper policy implementation and thus effective knowledge transfers (De Boer \& Bressers, 2011). 


\section{Chapter 7}

\section{Comparing the effectiveness of the case studies}

This chapter compares and reflects on the effectiveness of the case studies. For this, we build upon the evaluation model that was developed and applied to Case A in Chapter 3 and the evaluations of Case B and Case C, as presented in the case reports (Vinke-de Kruijf, 2011a, 2012). Before reflecting on the case study results, section 7.1 first provides a more general comparison of the case studies. Next, the chapter compares the case study processes (section 7.2) and their immediate and ultimate outcomes (section 7.3). Based on this crosscase analysis and the findings of previous chapters, section 7.4 identifies the factors that actually influence the effectiveness of knowledge transfer projects. Section 7.5 discusses how the cases score on alternative criteria. The last section summarizes our conclusions concerning the effectiveness of the case studies.

\subsection{Case study characteristics}

As discussed in Chapter 1, among the reasons for selecting the presented cases were that they were implemented with Dutch financial support, focused on flood risk reduction and involved Dutch organizations who wanted to transfer a Dutch concept, method or technology to Romania. Besides these common characteristics, the cases also have distinctive features. This section presents the main similarities and differences of the cases on the basis of the following questions: who? (actors involved), what and why? (project scope and objectives) and when, where and how? (implementation). Table 7.1 provides an overview of the cases using these questions. 
Table 7.1 - Characteristics of the three cases

Case A: 'Room for the River'
Case B: FLIWAS

Two Dutch consultants, a Romanian institute and a regional water authority (implementing team), Dutch foundation, Romanian

Who? Commissioner), Partners for Water (financial support) and other national, regional and local stakeholders (participants)

Develop integrated regional plans based on the flood strategy defined in a

What? Romanian study and using the Dutch 'Room for the River' approach

Improve safety and other functions in the area and Why? beyond and transfer of 'Room for the River' concept and an interactive design method

Aug. '06: explorations

Sept. '07: proposal

When? Nov. '08: proposal approved Feb. - Dec. '09:

implementation

Area along the Danube River in East Romania (between $167 \mathrm{~km}$ and $101 \mathrm{~km}$

Where? upstream of the Black Sea) including territory of the counties of Tulcea, Galaţi and Braila

Organize project team and

How? stakeholder meetings, interviews and an interactive design workshop
Ministry and national water authority (project support), Partners for Water (financial support) and regional and local stakeholders (participants)

Support the national and a regional Romanian water authority with the (pilot) implementation of a Flood Information and Warning System

Improve safety by means of better information in the transfer of FLIWAS method and technology

July '08: request April '09: explorations July '09: proposal Sept. '09 - April '10: implementation

Bucharest (collaboration with national authorities) and pilot area in West Romania (lower Timiş River, length of $120 \mathrm{~km}$ ) located in Timiş County (Banat regional water authority)

Provide support with the technical implementation of FLIWAS and organize trainings, communication and dissemination activities pilot area and beyond and
Case C: Integrated Water Management

Dutch water board, agency, water company, consultant, municipality and industry, and three Romanian municipalities, regional water authority, water company (implementing team), Netherlands Water Board Bank (financial support), authorities of various governance levels (consulting committee) and a few other local and regional stakeholders (participants)

Develop an integrated master plan for improved water management including measures for flood risk reduction and improvement of water services

Improve the water system and living conditions and develop collaboration and transfer of integrated water management concept and associated methods

Nov. '08: explorations June '08: proposal June '09: proposal approved Sept. '09 - June '11: implementation

Basin of the Tecucel River (length of $25 \mathrm{~km}$ ) in East Romania located in Galaţi County including one city and two small municipalities.

Organize meetings and workshops and a study visit and establish a project team and a consultative committee 


\section{Actors involved}

All three cases were implemented in collaboration between various Dutch and Romanian organizations. In two cases, the same Dutch organizations participated (with other persons and in different capacities): one consultancy company was involved in case A and B and one governmental agency in case B and C. In all cases, the Ministry of Environment was involved but represented by other persons and different departments. In case A, Romanian actors had a slightly different role than in the other cases. In this case, the Romanian actors who participated in the project team were paid for their contributions from the project budget. In the other cases, all Romanian actors represented governmental organizations and contributed human resources in kind. Case B was again organized slightly different as one Dutch actor and two Romanian actors were formally part of the project team but contributed less directly to the implementation of the project. Case A and B were financially supported by Partners for Water (covering up to $80 \%$ of the project costs) whereas case $\mathrm{C}$ was supported by the Dutch Water Board Bank (covering up to $50 \%$ of the project costs).

In addition to the project team members, all cases involved other actors in one or more project activities. The substantive reasons for involving these additional actors varied from case to case. Case A is a typical example of a participatory process that integrates the local knowledge of a wide variety of actors. Case B was a rather expert-oriented process in which most of the knowledge was provided by the project team members. Other persons with a role in flood risk management were invited for workshops in which they were informed and consulted. However, the participants did not really contribute knowledge. Also in case $\mathrm{C}$ most knowledge was provided by the members of the project teams. Other actors, including a local and regional non-governmental organization (NGO) were involved in the beginning but had a limited role in the actual process.

\section{Project scope and objectives}

All cases aimed at reducing flood risks and transferring Dutch knowledge. However, the exact project goals and the reasons behind the projects varied from case to case as well as from actor to actor. In discussing the project scope and objectives, we focus on the formal objectives that were defined by the Dutch teams. The designs of all cases were inspired by the idea that Dutch 'best practices' - which were not applied in Romania before - could support the realization of Romanian policy objectives. The objectives of case A and case $\mathrm{C}$ were to transfer an integrated planning approach. In case A, the plan was to integrate safety and other spatial functions into one regional plan. The realization of this plan was supported by the transfer of a concrete method (interactive design) and concept ('Room for the River'). Case $\mathrm{C}$ concerned the integration of safety and water services into one river basin plan. In this case, integration was promoted through improved collaboration between actors of various domains. What characterizes both case A and Case $\mathrm{C}$ is that they had the 
ambition to develop a plan that would be used for decision-making. Case B had another focus: it concerned the implementation of a new technology including a method of working. What all the cases had in common is that they were seen as stepping-stones for future Dutch-Romanian collaboration. Furthermore, they were designed not only for problem-solving purposes but also for creating economic opportunities for the Dutch water sector. Being a 'Partners for Water' project, case A and B were designed as pilot projects and therefore aimed at diffusion. Diffusion can be achieved by enlarging the scale of a pilot or by repeating a pilot at a comparable scale (Vreugdenhil, et al., 2010). Repetition of the pilot was an objective of case A, while scaling up was an important objective of case B. Diffusion played a less important role in case $\mathrm{C}$. This project primarily aimed at forming a basis for long-term collaboration.

\section{Implementation}

The cases are similar in the sense that they were all implemented in Romania between 2009 and 2011. One of the differences between the cases is the time between exploration and project finalization; this was only one year in case B and more than three years in case A and $\mathrm{C}$. The areas in which the cases were implemented differed both in size and location. In the cases, the size of the project area appeared to be an important characteristic since it has a direct influence on how many authorities need to be involved. What distinguishes case B from the other cases is that it was implemented in collaboration with regional actors as well as with actors at the head offices of the national authorities in Bucharest. As regards the organization of activities, all cases included various missions by Dutch experts to Romania. All missions included meetings (with project team members or invited participants) and sometimes workshops or a field visit. Most of the activities of case A were organized around a series of interactive design workshops. In case B, particular attention was paid to dissemination activities, such as the organization of a large national seminar and smallscale meetings with high-level representatives. In both cases, various Dutch and Romanian experts further worked side by side on technical matters for several days. These joint working days were not very successful in case A: Dutch experts worked at one of their Romanian partner organizations but worked little with Romanian experts. Of particular importance in case $\mathrm{C}$ was the establishment of a Romanian project team and consultative committee. Like the other cases, case $\mathrm{C}$ included meetings and workshops. In addition, small-scale meetings with high-level representatives and two study visits by Romanian experts to the Netherlands were organized.

\subsection{Evaluation of the process}

To distinguish an effective process from a less effective one, we developed a set of six process criteria: stakeholder involvement, institutional embedding, integration of contextspecific knowledge, mutual understanding in communication, proactive diffusion strategy and adaptive management (see also chapter 3 and table 3.1). These criteria are based on the 
notion that desired outcomes are more likely to be achieved if users - actors who can contribute to the realization of the desired outcomes - are engaged in the process. Engagement refers here not only to the actual involvement of various actors but also to the conditions in place that enable or promote interactions that support the realization of desired outcomes. Table 7.2 presents an overview of how the cases score on various process criteria. The subsections below discuss the evaluation results for each of the process criteria in more detail.

Table 7.2 - Overview of how the cases score on the process criteria with scores varying from high (good) to low (poor)

\begin{tabular}{|c|c|c|c|}
\hline Process criteria & Case A & Case B & Case C \\
\hline $\begin{array}{l}\text { Stakeholder } \\
\text { involvement }\end{array}$ & $\begin{array}{l}\text { Medium: high } \\
\text { involvement but no } \\
\text { power sharing and } \\
\text { limited information } \\
\text { provided }\end{array}$ & $\begin{array}{l}\text { Medium: information } \\
\text { and consultation well } \\
\text { organized but actual } \\
\text { involvement was } \\
\text { limited }\end{array}$ & $\begin{array}{l}\text { Low: actual } \\
\text { involvement much } \\
\text { lower than planned } \\
\text { and very limited } \\
\text { information provided }\end{array}$ \\
\hline $\begin{array}{l}\text { Institutional } \\
\text { embedding }\end{array}$ & $\begin{array}{l}\text { Low: only embedded } \\
\text { at the local level, } \\
\text { national embedding } \\
\text { failed }\end{array}$ & $\begin{array}{l}\text { High: high-level civil } \\
\text { servants at various } \\
\text { level were committed }\end{array}$ & $\begin{array}{l}\text { Low: only embedded } \\
\text { at the local level, } \\
\text { further embedding } \\
\text { failed }\end{array}$ \\
\hline $\begin{array}{l}\text { Integration of } \\
\text { context-specific } \\
\text { knowledge }\end{array}$ & $\begin{array}{l}\text { High: local knowledge } \\
\text { provided by various } \\
\text { actors was integrated } \\
\text { into designs }\end{array}$ & $\begin{array}{l}\text { Medium high: local } \\
\text { knowledge of the } \\
\text { water authority was } \\
\text { well integrated but not } \\
\text { of other stakeholders }\end{array}$ & $\begin{array}{l}\text { Medium: local } \\
\text { knowledge provided by } \\
\text { Romanian actors but } \\
\text { limited substantive } \\
\text { discussion }\end{array}$ \\
\hline $\begin{array}{l}\text { Mutual } \\
\text { understanding in } \\
\text { communication }\end{array}$ & $\begin{array}{l}\text { Medium: good } \\
\text { communication with } \\
\text { participants but some } \\
\text { misunderstandings in } \\
\text { the project team }\end{array}$ & $\begin{array}{l}\text { Medium: good } \\
\text { understanding } \\
\text { between most actors } \\
\text { but some } \\
\text { misunderstandings } \\
\text { between experts }\end{array}$ & $\begin{array}{l}\text { Low: difficult between } \\
\text { teams and } \\
\text { misunderstandings } \\
\text { between actors of the } \\
\text { same country }\end{array}$ \\
\hline $\begin{array}{l}\text { Proactive diffusion } \\
\text { strategy }\end{array}$ & $\begin{array}{l}\text { Low: concentrated at } \\
\text { the end and poorly } \\
\text { implemented }\end{array}$ & $\begin{array}{l}\text { High: only partly } \\
\text { planned but well } \\
\text { implemented at } \\
\text { various points in time }\end{array}$ & $\begin{array}{l}\text { Low: vaguely } \\
\text { formulated strategy } \\
\text { and poorly } \\
\text { implemented }\end{array}$ \\
\hline $\begin{array}{l}\text { Adaptive } \\
\text { management }\end{array}$ & $\begin{array}{l}\text { Medium: well adapted } \\
\text { to new insights but not } \\
\text { to changing political } \\
\text { situation }\end{array}$ & $\begin{array}{l}\text { Medium: well adapted } \\
\text { to process dynamics } \\
\text { but not to technical } \\
\text { problems }\end{array}$ & $\begin{array}{l}\text { Medium: adaptations } \\
\text { were only made } \\
\text { halfway and } \\
\text { unproductive }\end{array}$ \\
\hline
\end{tabular}

\section{Stakeholder involvement}

Stakeholder involvement focuses on the involvement of persons who have no formal position in the decision process but are potentially affected by a project or can provide relevant knowledge. This criterion is based on the notion that, in order to be effective, water 
projects should take into account the interests of those who work and live in the project area (Wesselink, 2007a). In all cases, the involvement of such persons was part of the project proposal. However, the actual level of stakeholder involvement varied among the different cases. In case A, local stakeholders were well represented in various meetings and workshops and expressed their support for the outcomes. However, they were not in the position to implement the outcomes. For this, they depended on the support of national authorities who ignored the project results. Thus, the participating stakeholders had no influence on the decision-making process. In case B, the plan was to involve not only water managers but also other persons with a formal role in emergency situations. The actual participation of the second group was rather low. Those who were present at meetings and workshops were consulted but could contribute little knowledge. A strong aspect of case B was that many actions were undertaken to ensure the dissemination of information about the project. Regional and national media were represented at meetings, presentations were given about the project at various occasions and a final seminar was organized for which, among others, other regional water authorities were invited. In case $\mathrm{C}$, the involvement of stakeholders was arranged through the active involvement of local public authorities. The plan was to also actively involve persons from the area in a series of interactive design workshops (as was done in case A). However, due to air traffic problems this activity was initially postponed. Because of new insights the activity was eventually taken out. In this project, there was also little attention for disseminating information about the project to inhabitants. Two NGOs were invited to participate in meetings but only in the beginning of the process. Therefore, the overall stakeholder involvement in this case was low.

\section{Institutional embedding}

Institutional embedding measures the degree to which civil servants, executives and politicians are involved in the process. This is particularly relevant for projects that are implemented at a distance of formal policy processes, since such projects easily run the risk of having no policy impact (Edelenbos, et al., 2008). In case A and C, the institutional embedding was rather poor. Case A was developed in close collaboration with the Ministry of Environment. A high-level civil servant of this Ministry attended the first meeting and a civil servant participated in most project activities. Local, regional and national actors at decision-making positions were invited for meetings. However, their actual participation was limited: only local representatives were actively involved in most of the meetings and workshops. Case $\mathrm{C}$ had a very local-oriented approach, implying that its focus was on close collaboration with and between local actors. To gain the necessary institutional and financial support, a consultative committee was established with high-level executives of the Ministry of Environment and of regional and local authorities. This committee did not function very well and was far less effective than hoped for. The institutional embedding of case B was much better organized. This case was designed and implemented in collaboration with actors at the national level and at the regional level. Actors at decision- 
making positions were consulted at the beginning and at the end of the project and informed throughout the project. Local authorities were also invited for meetings but had little interest to participate.

\section{Integration of context-specific knowledge}

External experts have limited access to knowledge of local conditions and social patterns. Therefore, the creation of context-specific and negotiated knowledge requires the integration of external experts' knowledge with the context-specific knowledge of experts and stakeholders of the benefiting country (Gummesson, 2000; Hommes et al., 2009a; Leeuwis \& Van den Ban, 2004). In all cases, an important means of integrating general and context-specific knowledge was the formation of a project team with Dutch and Romanian experts. The integration of knowledge was often problematic, since on several occasions various experts had difficulties to understand each other. Case A was most successful in the actual integration of general and context-specific knowledge. The regional plans clearly include both the general knowledge of Dutch experts associated with the development of 'Room for the River' measures and the local knowledge of experts and stakeholders about the existing situation. In case B, knowledge of the regional water authority was successfully integrated. However, Romanian actors doubted the actual usability of FLIWAS, since knowledge of other regional and local actors was not integrated. What distinguishes this case from the other cases is that various Dutch experts could also contribute contextspecific knowledge since they worked in Romania before. In case C, problems arose with the integration of knowledge about the existing situation. Most context-specific knowledge was provided by members of the Romanian team and by external consultants but it took much longer than expected. Like in case B, stakeholders hardly played a role in the creation of a knowledge base.

\section{Mutual understanding in communication}

Actors involved in international projects tend to have difficulties in understanding each other due to their diverse socio-cultural, organizational and professional backgrounds (Stenmark, 2002). The criterion of 'mutual understanding in communication' measures the degree to which actors involved are able to overcome language barriers and other differences, for example, by using figurative language (Koskinen, et al., 2003). In all cases, translators were involved to overcome language barriers. In case A and B, key experts spoke English but most of the Romanian experts in case C could only speak Romanian. As a result, experts of the Dutch team and the Romanian team had limited direct communication; most communication went via the Dutch project leader and the Romanian project secretary. In case A and B, experts spoke the same language but still had difficulties to understand each other at various occasions. In case A, communication lines and responsibilities were unclear to the Romanian experts. Dutch experts were disappointed about the level of expertise and the adequacy of responses of some of their Romanian 
counterparts. In case B, most of the experts had no problems in understanding each other but there were at least two occasions on which experts experienced serious communication problems. In all cases, the organization of field visits to the project area helped to develop a common understanding. In addition to a field visit in Romania, case $\mathrm{C}$ also included a study visit to the Netherlands in which Romanian experts visited various sites. In all cases, the development of a mutual understanding was further enhanced by means of visualization techniques. In case A, landscape architects visualized the ideas of stakeholders in various workshops. This technique was also applied at a small-scale (for testing purposes) in case C. An example of visualization in case $B$ is the schematization of the FLIWAS environment.

\section{Proactive diffusion strategy}

Dutch-funded knowledge transfer projects are generally planned to become a basis for follow-up actions and can therefore be seen as pilots or test cases. Poor diffusion management is one of the reasons that such projects are - even when they have been successful - not repeated at a larger or similar scale. The criterion of 'proactive diffusion strategy' focuses on measures that enhance the impact of pilot projects, such as the inclusion of a diffusion strategy in the project plan and the implementation of such plan in an early stage of the pilot (Vreugdenhil, et al., 2010). Case A and B were both pilot projects with explicit diffusion objectives. However, the projects' diffusion was only well taken care of in case B. The diffusion strategy that was proposed in case A consisted of presentations for decision-makers and the development of a project brochure. The strategy was not proactive as most actions were planned at the end of the project. Furthermore, it was poorly implemented: most of the presentations were aborted or not attended by the intended audience. Compared to case A, the project plan of case B included very few diffusion activities. The only activity that was planned in advance was the organization of a final seminar. However, unlike the other cases, this project included a communication component that was implemented by a separate group of experts. At the beginning of the project, these experts formulated a communication plan in which they elaborated additional diffusion activities. In addition to the final seminar, the project included many diffusion activities: progress meetings were organized, media were regularly invited, promotion materials were produced, press releases were written and the project was presented at various occasions. As regards case $\mathrm{C}$, its project plan included various activities that aimed to promote the project's diffusion. However, the defined diffusion strategy was rather vague: it did not specify target groups or concrete diffusion objectives. Furthermore, many of the planned diffusion activities (i.e. the organization of a final seminar, the production of reports and the organization of interactive design workshops) were never implemented. 


\section{Adaptive management}

Adaptive management is measured by the degree to which a project is a flexible process in which goals and means are adapted to changing conditions or circumstances, new insights and other emergent dynamics (Leeuwis \& Van den Ban, 2004). This criterion is based on the recognition that water projects are implemented in a dynamic context that is characterized by uncertainty and ambiguity and therefore requires a learning-oriented approach (Pahl-Wostl et al., 2007b). In case B and C, adaptations had to be made already in the preparation phase. Case B was initially planned to be implemented in Slovakia. When this did not work out, an adjusted plan was prepared for the remaining budget to implement FLIWAS in the Romanian context. In case $\mathrm{C}$, the project proposal was first submitted to Partners for Water, which could not finance any project in that tender round. The Dutch team adapted to this by submitting a similar proposal to another funding agency and by financing a larger share of the project costs themselves. More importantly, there was a need in all cases to adapt the initial plan - for various reasons - during the project. However, none of the cases was very successful in this respect. In case A, socio-economic issues appeared to be more important than flood-related problems. The project scope was expanded in order to adjust the project for these new insights in the local reality. In addition, the institutional and political contexts of the project changed. Just before the project started, the State Secretary for Water, who supported the project, was replaced. Moreover, the Romanian government was dissolved just before the project ended. The project was not adapted in response to these changes. Case B was not affected by changes in the wider context, probably because the period between the project preparations and its finalization was relatively short. However, adjustments had to be made in response to internal developments, including illness of the project leader and delays in the installation of the Romanian server. Changes that were made included the replacement of the project leader and the implementation of the data at a Dutch instead of a Romanian computer server. The latter adjustment was not effective since data were never transferred from the Dutch to the Romanian server. In case B there was also a need to partly adapt the technical implementation plan to local reality resulting in the less complete implementation of the pilot. Thus, the adaptations often did not improve the effectiveness of the project. The institutional and wider contexts of case $\mathrm{C}$ changed considerably during its implementation. Of particular influence on the project was the approval of two master plans. This development made the Dutch team decide to abstain from drafting another master plan. Furthermore, the Dutch team decided not to organize a series of interactive design workshops. These workshops were first postponed in response to air traffic disruption and later omitted in response to new insights. In case $C$, adaptations caused that the project had no concrete outcome. They were not effective since they were made only halfway the project and primarily involved elimination of project activities. 


\subsection{Evaluation of immediate and ultimate outcomes}

Recent policy documents show that the actual purpose of Dutch-funded water projects is twofold: (1) to contribute to the solving of water-related problems in the benefiting country; and (2) to generate new projects for the Dutch water sector. To understand to what degree the cases contribute to these 'ultimate outcomes', we question: Does the project contribute to problem solving or are the project results a basis for (future) problem-solving? Does the project result in follow-up or similar projects for the Dutch water sector or do the project results form a basis for follow-up actions? We predict the realization of ultimate outcomes on the basis of 'immediate outcomes'. These immediate outcomes are associated with changes in actor characteristics and relational experiences. They measure the degree to which relevant actors: (1) develop a joint motivating goal; (2) create a negotiated knowledge base: (3) mobilize necessary resources; and (4) have positive relational experiences (see also chapter 3 and table 3.1). Table 7.3 presents an overview of how the cases score on these immediate and ultimate outcome criteria. The evaluation results are for every criteria explained in more detail in the subsections below.

\section{Joint motivating goal}

Realization of the ultimate outcomes depends, among others, on whether actors actively or passively (depending on their obstruction or realization power) support these outcomes (Owens, 2008). In case A, most of the Romanian participants were positively surprised to see that the regional plans reflected their ideas and valued the results. They supported the further development of the plans but emphasized that the national government should take the lead in this. However, the government did not want to make any commitment to the results. The actors involved did not develop a joint motivation for the implementation of any specific follow-up actions. In case B, Dutch and Romanian actors (including actors at decision-making positions) became very motivated to jointly work on follow-up projects that would contribute to the further implementation of FLIWAS. However, the prospect of follow-up also made project participants less motivated to start using FLIWAS next to their existing warning and information systems. Two factors that played a role in this were that the implementation process was not fully completed and that it was unclear who should take the necessary additional steps. Case $\mathrm{C}$ was disappointing for actors of both countries since the adopted approach was less effective than hoped for. During the project, the motivation of the Dutch team gradually diminished, not only because the project approach was not effective but also because they had the impression that their Romanian counterparts were not committed. The motivation of Romanian actors increased, despite the project results, since they learnt a great deal. However, some of the Dutch-Romanian interactions in the periphery of the project motivated a Dutch water company to further collaborate with a Romanian regional water company. 
Table 7.3 - Overview of how the cases score on the immediate and ultimate outcome criteria with scores varying from high (strong or very likely) to low (weak or very unlikely)

\begin{tabular}{llll}
\hline Outcome criteria & \multicolumn{1}{c}{ Case A } & \multicolumn{1}{c}{ Case B } & \multicolumn{1}{c}{ Case C } \\
\hline Joint motivating goal & $\begin{array}{l}\text { Medium: participants } \\
\text { became motivated } \\
\text { but powerful actors } \\
\text { not }\end{array}$ & $\begin{array}{l}\text { Medium: strong } \\
\text { support for follow-up } \\
\text { but no joint motivation } \\
\text { to start using FlWAS } \\
\text { already }\end{array}$ & $\begin{array}{l}\text { Medium low: Dutch } \\
\text { became less and }\end{array}$ \\
$\begin{array}{lll}\text { Romanians more } \\
\text { motivated to } \\
\text { collaborate }\end{array}$ \\
Negotiated knowledge & $\begin{array}{l}\text { Medium high: validity } \\
\text { was questioned but }\end{array}$ & $\begin{array}{l}\text { Medium: common } \\
\text { view on the process }\end{array}$ & $\begin{array}{l}\text { Medium: common } \\
\text { view on the existing }\end{array}$ \\
& $\begin{array}{l}\text { the content of the } \\
\text { plans were not } \\
\text { contested }\end{array}$ & $\begin{array}{l}\text { but not on the } \\
\text { usefulness and use of }\end{array}$ & $\begin{array}{l}\text { situation but not on } \\
\text { how to deal with }\end{array}$ \\
issues
\end{tabular}

\section{Negotiated knowledge}

Whether ultimate outcomes are achievable depends not only on the availability of required information but also on the degree to which relevant actors create a knowledge base that is relevant, agreed upon and scientifically valid (De Bruijn, et al., 2010; Koppenjan \& Klijn, 2004; Van de Riet, 2003). The cases show that the creation of such a negotiated knowledge base is anything but straightforward. In all cases, actors developed a shared understanding of some but not of all aspects of the project and potential follow-up actions. In case A, actors were closely involved in the development of the regional plans and arrived at agreed upon directions for solutions for the area. They also agreed that the involvement of Dutch experts was of added value. However, several Romanian actors questioned the validity of 
the effects of the regional plans on the water level, which were calculated by Dutch experts. Actors concluded that additional research was needed to validate these calculations. In case $\mathrm{B}$, relevant actors had to agree upon the implementation, use and usefulness of FLIWAS in the Romanian context. Actors involved in the implementation process reached an agreement on how to implement and use FLIWAS. However, Romanian actors never really started using FLIWAS. Romanian participants continued to have doubts about whether the Romanian context was yet ready for a tool like FLIWAS. Dutch actors had another opinion on this. To them, the pilot proved that FLIWAS was potentially useful in the Romanian context. Their view was shared by Romanian actors at decision-making positions. For the further implementation of FLIWAS, Romanian actors perceived that Dutch expertise would be indispensable. In case $\mathrm{C}$, actors involved only developed halfway through the project a common understanding of the problems in the area and relevant policy developments. This understanding led actors involved to the conclusion that the development of an integrated master plan was no longer needed. The added value of Dutch expertise was explicitly discussed and more or less agreed upon. However, the teams never reached an explicit agreement about other project aspects, such as, whether to implement an interactive design workshop, how to elaborate what measures and who should be involved in any follow-up projects.

\section{Mobilization of resources}

For the realization of ultimate outcomes, it is crucial that all necessary resources are available and accessible (Bressers, 2004). This includes human resources (people), information resources (knowledge), financial resources (funds) and institutional resources (power to get things done). The cases demonstrate that follow-up actions easily get stuck in a lack of financial resources. In case A, several actors were interested to involve Dutch experts in a similar project or to implement the resulting plans. Since none of these actors was in the position to finance such activities, follow-up actions depended on the mobilization of external financial support. Several actors tried to enhance the mobilization of resources, for example, by organizing themselves (local actors) or by raising attention for the project at the national level (one Dutch actor and two Romanian actors). However, actors were also pointing towards each other and did not agree on who should take the lead in pushing for follow-up actions. In case B, the Dutch actor who led the project also took the lead in the mobilization of resources for follow-up projects. They also trained Romanian experts in the administration and use of FLIWAS. One of the problems in this case was that no actor was made responsible for the finalization of the implementation process, which included the transfer of data from the Dutch to the Romanian server. Like in Case A, actors were pointing towards each other. In case C, actors initially focused on the mobilization of institutional support for the project by establishing a consultative committee. Later on, Dutch experts identified two follow-up projects for which they separately tried to mobilize support and financial resources. None of the attempts to raise 
institutional support was successful. As in case A, none of the Romanian actors who participated in the project was in the position to finance concrete follow-up projects. However, two Dutch actors and one Romanian actor (a regional water company who was not directly involved in the project) were able to mobilize support for a partnership within their own organizations.

\section{Positive relational experiences}

The resources needed for the realization of ultimate outcomes are usually spread among various actors. Hence, there is a need to collaborate. Such collaboration is more likely when actors have developed a collective resource: trust (Bressers, 2009). When actors interact with each other over a longer period of time and these interactions are positive, they become more willing to trust, and thus to continue their cooperation. Negative relational experiences have the opposite effect (Rousseau, et al., 1998). In the cases, the Romanian actors generally had very positive relational experiences. Dutch actors were predominantly positive about their collaboration with each other, but often critical about their collaboration with their Romanian counterparts. In all cases, Dutch experts mentioned that their Romanian counterparts were more awaiting and less proactive than expected. Moreover, (some of the) Romanian counterparts in case A and C did not contribute to the project as expected. As a result, Dutch experts started to doubt their motivations and capacities. This was different in case B in which Dutch actors emphasized the commitment of their counterparts: they were available and providing input when needed. Romanian actors were predominantly positive about their collaboration with each other and with their Dutch counterparts. One of the exceptions is an expert in case B who had a very difficult collaboration with a German company that was hired to support the implementation of the computer server. In all cases, various Romanian actors mentioned that, as a result of the project, they became more willing to collaborate with one of the other Romanian organizations involved. The same applied to Dutch actors: they were generally positive about future collaboration with one of the other Dutch organizations.

\section{Problem-solving}

This criterion measures the degree to which a project contributes - directly or more indirectly - to the realization of environmental outcomes, which usually involves a change in environmental conditions (Mandarano, 2008). Case A and C focused on the development of a plan, which is the first step in problem-solving. Such planning projects only contribute to problem-solving if they are followed by a decision whether or not to continue the implementation of the plan. Only after actors agree on action, changes can be made to the physical environment, which hopefully result in the desired changes in environmental conditions (Owens, 2008). In Case A, local actors strongly supported some of the plans that were developed in the project. However, without the support of national actors they are not able to implement such plans. National actors were invited to react upon the plans but 
decided to ignore them instead. One of the problems is that the implementation of 'Room for the River' measures is rather controversial in Romania. Hence, until recently a national programme, as adopted in the Netherlands, was unlikely to be developed in the short or the medium term (Vinke-de Kruijf et al., 2012). However, in the past few years the attention of national water managers for the project and 'Room for the River' measures has been growing. A combination of factors probably contributed to this development. First of all, the project is a very successful example of how participation can contribute to the development of widely supported, concrete outcomes. Secondly, the project got attention in various Dutch-Romanian meetings on water management and in another Dutch-Romanian project. Thirdly, there is a strong pressure from the European Commission to invest in measures that create more space for the river. In addition, the visual way in which the project outcomes were presented makes them attractive and something to remember (personal communication). Thus, even though the project was - and probably is - rather controversial in Romania, external developments are currently opening new 'windows of opportunity'. The objective of case $\mathrm{C}$ became to realize two concrete measures that were not included in existing master plans (instead of developing an integrated master plan). Both measures were not viable since they only had priority at the local and not at the regional or the national level. This project therefore had no concrete outcome but there are concrete indications that the project contributed to the solving of water-related problems in the area. According to Romanian actors, the project helped to identify a solution for the separation of sewage and pluvial water and increased their capacity to deal with multi-actor problems. Furthermore, two of the Dutch organizations decided to engage in a water partnership with a regional water company for the next three years. This partnership was not an outcome of the project since the company was not one of the formal project partners. Nevertheless, it was a direct result since the partnership emerged from contacts that were established during the project course. The partnership is expected to contribute to the reduction of water services problem in the region, which includes the project area. Compared to Case A and C, case B had another focus: this project was expected to contribute to the reduction of flood-related problems by providing the right persons with the right information at the right time. The realization of this objective crucially depends on whether FLIWAS is adequately implemented and used. Water managers could start using FLIWAS next to their existing systems but decided not to do so. What plays a role in this is that actors cannot really benefit yet from the application since the pilot implementation was never finalized. The pilot could still contribute to problem-solving: actors were trained in the use of FLIWAS and developed a better understanding of the emergency management system and the pilot proved - especially to national authorities - that FLIWAS is, in principle, a useful tool in flood risk management. 


\section{Follow-up projects}

This criterion is based on the recognition that 'strengthening the position of the Dutch water sector' is one of the main reasons of the Dutch government to finance international water projects (Min V\&W, 2007, 2009). The generation of follow-up projects for the Dutch water sector was an objective of all cases. However, none of the studied cases was very successful in this respect. In case A, Dutch organizations promoted follow-up actions. Furthermore, various Romanian counterparts mentioned that the involvement of Dutch experts was likely in case of any similar future project. Such project could be a direct follow-up of the implemented project or a similar project that would benefit, for example, from an interactive design workshop. Up to our knowledge, the project did not yet lead to any concrete follow-up project for one of the Dutch organizations involved. However, as explained in the previous section, this may change in the near future. In addition, some of the project results served as input for Case C and for another 'Partners for Water' project (personal communication). In case B, Dutch organizations had concrete discussions with the Romanian Ministry of Environment about follow-up projects. These discussions led to the inclusion of a 'tool like FLIWAS' in a project proposal on transboundary flood risk management. Furthermore, the implementation of FLIWAS at another regional water authority was seriously considered within the context of the collaboration between Romanian County of Teleorman and the Dutch Province of Overijssel. However, this did not lead to a concrete project. In addition, one of the Dutch organizations mentioned that it included the further implementation of FLIWAS at the Romanian regional water authority in a project proposal. Another indirect, but important, follow-up is that the Dutch consultancy company, which was involved in case A and B, recently won a tender for a project on flood risk management in Romania (Website $\mathrm{HKV}, 2011$ ). In case $\mathrm{C}$, the partnership was the most concrete follow-up of the project. This may eventually create economic opportunities for the Dutch water sector but this is not part of the partnerships' objectives or being expected. Local Romanian counterparts were interested to continue the Dutch-Romanian collaboration but did not have any concrete idea for projects that would also have economic benefits for the Dutch water sector. Moreover, the confidence of Dutch commercial organizations in Romania as an attractive market diminished during the project course.

\subsection{Factors that influence the effectiveness of knowledge transfer projects}

The previous section showed that, up to now, the studied cases did not contribute directly to the solving of water-related problems and had no follow-up projects that economically benefit the Dutch water sector. In this section, we try to explain these outcomes based on the process criteria and the immediate outcome criteria. The first subsection reflects upon the causal relations between the process and its immediate and ultimate outcomes. Then, we 
reflect on the relation between the immediate and ultimate outcomes. The remaining subsections discuss to what degree various process criteria explain the effectiveness of the case study projects.

\section{Correlation between the process and its outcomes}

In analysing the effectiveness of the case studies, we assumed a direct relation between the interactive process and its outcomes. More specific, we expected that the engagement of actors with a crucial role in the implementation of the project or follow-up actions lead to immediate outcomes, which form a basis for further collaboration and the realization of ultimate outcomes. The easiest method to verify the validity of these relations is to quantify how the cases score on various process criteria (Table 7.1) and outcome criteria (Table 7.2). Figure 7.1 shows the calculated relations between the process and its immediate and ultimate outcomes. Both figures are based on averages of the calculated scores (all criteria are given the same weight) using a ratio scale $(+2$ for high/good/strong score, 0 for a medium score and -2 for a low/poor/weak score).
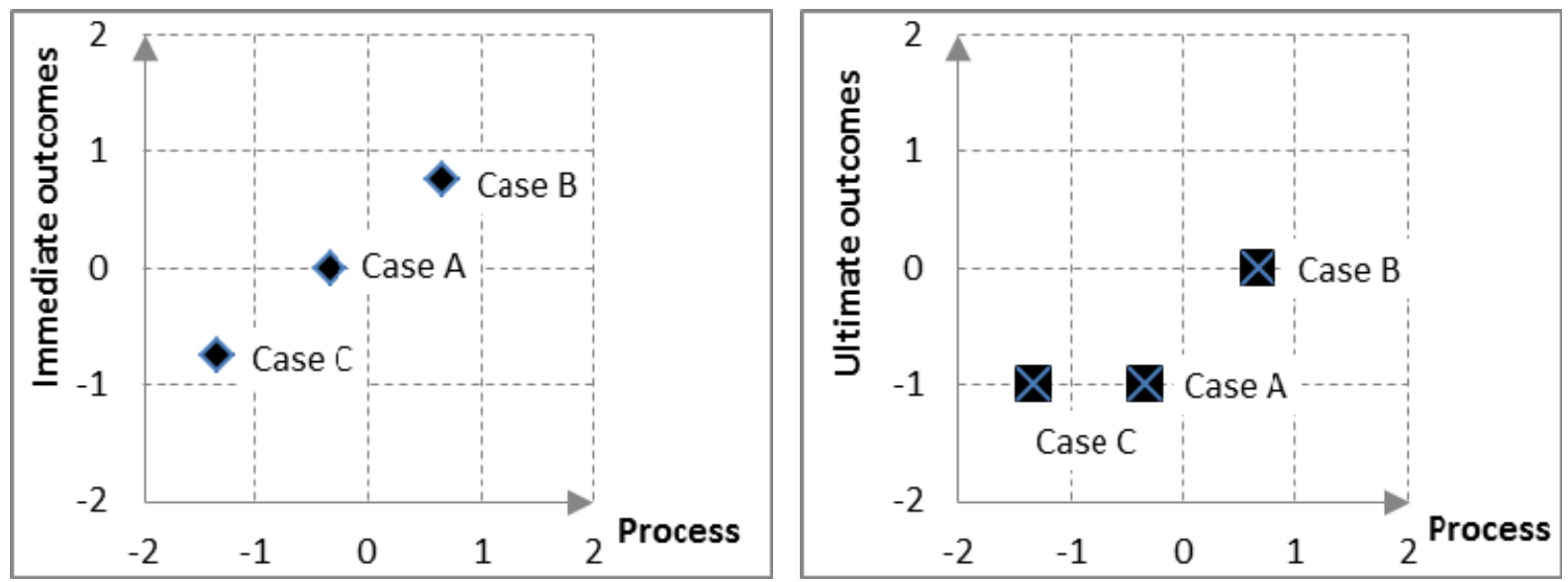

Figure 7.1 - Calculated relation between the average process score and the average immediate outcome score (left side) and the average ultimate outcome score (right side)

Figure 7.1 shows that, for the studied cases, there is a strong correlation between the process criteria and the immediate outcome criteria. The ultimate outcomes are also correlated with the process, but this relation is weaker. These correlations are an interesting result since the framework was never developed for the purpose of being tested using quantitative methods. In fact, they are criteria associated with user engagement and based on diverse literature streams. The criteria were developed in a qualitative manner and meant to explain the effectiveness of projects and also to guide practitioners in designing and implementing a project. As a result, the criteria are partly overlapping and interacting with each other. For example, when stakeholders are involved and a process is adapted to new insights, it is likely that a project also scores high on the integration of context-specific knowledge. Moreover, there is a strong correlation between institutional embedding and the presence of a proactive diffusion strategy (see Table 7.2). This is understandable since both 
criteria reflect the proactive involvement of institutional actors. An in-depth quantitative analysis of the relations between various criteria could provide additional insights in the correlations between criteria and the relative importance of certain criteria. However, the number of studied cases is very limited implying that such an analysis cannot lead to any scientific proofs. Therefore, instead of analysing these various relations using quantitative methods, we use qualitative reasoning to draw more general conclusions on the factors that contribute to the effectiveness of knowledge transfer projects.

\section{Immediate outcomes as a basis for the realization of ultimate outcomes}

The immediate outcome criteria were derived from the predictive part of the Contextual Interaction Theory as developed by (Bressers, 2004) and tested by (Owens, 2008) in a large-N study. We used the assertions of their two-actor model of implementation as a basis in the development of a multi-actor model in which the realization of ultimate outcomes can be predicted on the basis of collective immediate outcomes (see Chapter 8 for a more thorough discussion). In Chapter 3, we argued that case A confirms an important finding of previous research, which is that the realization of ultimate outcomes often 'gets stuck in a lack of financial resources'. While actors involved become motivated and agree upon a relevant knowledge base, they fail to mobilize the external resources that are needed for the implementation of follow-up actions (Owens, 2008). Also in the other cases, we found that the actors involved did not have access to sufficient financial resources and therefore had to mobilize external resources for the realization of desired follow-up actions. Thus, projects were often developed by one group of actors but another group of actors was needed to move towards implementation. In Chapter 3, we recognized the need to switch actor arenas and introduced the term 'user', which we defined as an actor who needs to be involved in the project or in follow-up actions in order to realize ultimate outcomes. However, when 'users' are not necessarily the same persons as the actors involved, there is also no causal relation between the immediate outcomes of a project (generated by actors involved) and its ultimate outcomes (realized by 'users'). Thus, we assumed, and the cases confirm, that the defined (collective) immediate outcomes are necessary but insufficient for the realization of desired ultimate outcomes. In other words, when actors develop a motivating goal, create a negotiated knowledge base, mobilize resources (by pooling them) and have positive relational experiences, they have a strong and necessary basis for the realization of ultimate outcomes. However, such a basis is often insufficient since resources for the implementation of the desired outcomes need to be provided by external actors (who need to become motivated for the same goal, agree upon the same knowledge base and also trust the other actors). Thus, immediate outcomes only partly predict the realization of ultimate outcomes.

Regarding the influence of immediate outcomes on the ultimate outcomes, our initial finding that follow-up 'gets stuck in a lack of financial resources' requires some nuance. At first sight, this conclusion seems to apply to all cases. However, in case B follow-up is 
likely even though actors depend on the mobilization of external resources. The difference between this case and the other cases is that in case B a Dutch consultant and the Romanian ministry decided to take the lead in the mobilization of resources. At the same time, case B is not likely to contribute to problem-solving since actors involved did not start using FLIWAS. This closely relates to the incomplete installation of FLIWAS: to really benefit from the application, it should be connected to an automated measurement system. Such a connection was not created because it would take too much time and because FLIWAS was not yet installed at the Romanian server. For this, data still need to be transferred from the Dutch to the Romanian server. However, no actor takes the lead in this and actors are pointing towards each other. The analysis of actor characteristics shows that the incomplete installation is related to a lack of motivation at the Romanian side. However, one of the reasons that Romanian actors are not motivated to start using FLIWAS is that they doubt the usefulness of the application in the current Romanian context. This cognition is unlikely to change as long as they do not start using FLIWAS. An additional explanation for the passive attitude of actors is that they expect and wait for follow-up projects. We made similar observations in case A. This project also resulted in a situation in which actors were waiting for and pointing towards each other. Actors involved initially assumed that the ministry (as project commissioner) would take the lead in the mobilization of resources for follow-up actions. When the ministry did not do so, there was also no other actor who decided to take the lead in mobilizing resources. These examples show that follow-up actions tend to get stuck in the absence of an actor who is able and willing to coordinate or to take the lead in the mobilization of (external) resources.

The cases confirm findings from research on problem-solving in multi-actor networks, which show that network management (e.g. the efforts of a ministry in bringing parties together) is one of the factors that influences the course and outcomes of problem-solving processes. This influence is indirect: it influences the actors and their interactions and therefore also the interactive process (Koppenjan \& Klijn, 2004). The conclusion that the effectiveness of a project highly depends on motivations and network management does not deny the importance of cognitive and relational aspects. The cases demonstrate that how actors experienced the collaboration and whether actors developed a negotiated knowledge base has a direct influence on their motivation. The negative relational experiences of Dutch actors in case $\mathrm{A}$ and $\mathrm{C}$ were demotivating and made them less willing to invest additional time in the project. Also the lack of an agreed upon knowledge base played a role: Romanian actors either had their doubts about the usefulness of the knowledge that was transferred (participants of case B and external actors in case A) or about what problems to deal with and how (participants of case C).

The presented cross-case evaluation highlights that knowledge transfer projects, even when lacking any direct follow-up, can have important indirect outcomes. The most concrete examples are the water partnership that resulted from case $C$ (positive influence on the solving of water services problems) and the winning of a project tender by a Dutch 
consultant (positive influence of Dutch-funded projects on the economic position of the Dutch water sector). In these examples there was no direct relation between the project and the realization of policy outcomes. This corresponds with the idea that problem-solving often has the form of a 'zigzag and erratic' process. Their outcomes do not result from a single interactive process but from 'interaction rounds'. Each of these rounds has intermediate substantive, relational or institutional outcomes that, if coordinated properly, can form building blocks for the realization of ultimate outcomes (Koppenjan \& Klijn, 2004).

\section{The crucial importance of institutional embedding}

Chapter 6 elaborated how contextual factors influence the effectiveness of the cases. Based on this analysis, we concluded that the case studies demonstrate that in particular the involvement and support of national actors affects a projects' effectiveness. This conclusion is supported by previous research findings, which show that the successful transfer of knowledge crucially depends on the degree to which powerful actors are 'pulling in'. This means that dominant actors are motivated to change their ways and convinced that the transfer is useful (Kroesen, et al., 2007). In the case studies, we measured this aspect through the criterion 'institutional embedding', which we derived from a study on the policy impact of interactive policy making. The criterion measures the degree to which an interactive process is connected to formal decision-making processes. The quality of this connection is very high if civil servants are actively involved (administrative-bureaucratic embedding), executives express their commitment and are regularly present at activities (executive embedding) and politicians are actively involved (representative-political embedding) (Edelenbos, et al., 2008). Along similar lines, researchers show that social learning processes that occur in informal actor networks are important for transitions in water management to occur. However, they are unlikely to have sustainable impacts when connections to formal policy makers are missing. Such a connection can be created by means of formal representation but also by involving institutional actors or by transferring knowledge to these institutions (Pahl-Wostl et al., 2010).

Of the studied cases, only case B was rather successful in terms of institutional embedding. This partly relates to the project's design: the development of a national FLIWAS environment was combined with a regional pilot. In the case, both at the regional and at the national level, civil servants were closely involved and actors at decision-making positions (directors) were regularly involved and expressed their commitment. Chapter 4 presented an in-depth analysis of the case study using the literature on knowledge transfer and management. We concluded that follow-up actions were enhanced by the involvement and commitment of champions, which are key actors that are able to promote and push the adoption of new ideas (Trott, et al., 1995). The involvement of these actors probably also contributed to the executive embedding of the project. Even though the State Secretary was not involved, this executive expressed in the last meeting that he had received positive 
information about the project from various directors and therefore supported further implementation of FLIWAS. Case A had a similar objective as case B: the project was planned to be a regional pilot that would feed back into a national programme. However, case A was far less successful in this respect. The case demonstrates the importance of adapting strategies for diffusion and institutional embedding in case of changes in the institutional context. Case $\mathrm{C}$ had another focus since it started as a local-oriented process. The institutional embedding of this committee was only organized at a later stage through the establishment of a consultative committee with regional and national actors. With hindsight, several actors noted that the institutional embedding of the project was too little and too late. We cannot prove that the closer involvement of actors with decision-maker power in case $\mathrm{A}$ and $\mathrm{C}$ was feasible and would have made a difference. However, the cases give reason to conclude that the involvement and commitment of actors at decision-making positions, who can act as champion, has a positive influence on a projects' potential to initiate follow-up actions. In the cases, politicians did not really play a role (with the exception that one of the key regional actors in case B was in politics, which may have played a role). Comparative research on knowledge transfer shows that politicians do not need to play a role in knowledge transfer projects. Some decisions are simply not important enough to require significant political involvement. Only if projects are politically significant, such as large infrastructure projects, politicians tend to come more to the fore (Marsden \& Stead, 2011). The adoption of a national 'Room for the River' programme (which would support the implementation of case A) is an example of a decision that requires not only administrative but also political support.

\section{Interrelations between institutional embedding, a proactive diffusion strategy and context-specific knowledge}

In the previous subsection, we concluded that the cases demonstrate that follow-up actions largely depend on institutional embedding. However, this does not imply that the other process criteria become irrelevant. As explained before, the case studies show a strong correlation between institutional embedding and a proactive diffusion strategy. Effective diffusion means that newly developed knowledge feeds back into policy and management practices. This can be enhanced by including an explicit diffusion strategy and putting this strategy in place at an early stage of the project (Vreugdenhil, et al., 2010). The cases demonstrate that the inclusion of a diffusion strategy in the project proposal does not have to contribute to actual diffusion. Both case $\mathrm{A}$ and $\mathrm{C}$ included diffusion strategies but they were poorly implemented. Both cases also score low on institutional embedding. The proposal for case $\mathrm{B}$ did not include a diffusion strategy but a proactive strategy was developed at the beginning of the project. This strategy paid attention to various aspects, such as the provision of information to the general public, the consultation of actors with a role in emergency management and the organization of a final seminar for various actors with a role in flood risk management. Probably even more important was that the project 
included regular meetings with directors of key institutions. By doing so, the project team created a formal connection between the project and regular policy processes and also made sure that knowledge was feeding back to actors with a key role in the adjustment of policy and management practices. Thus, since governmental actors have a key role in water management, proactive diffusion and institutional embedding are likely to go hand in hand in water-related projects.

Who should be included in a proactive strategy for institutional embedding and diffusion depends on the governance context of a project. We analysed the flood risk governance context of the cases in Chapter 2. This analysis showed that flood risk policies and plans in Romania are basically developed and implemented by the Ministry of Environment and the National Administration for Romanian Waters. While both organizations have a key role in flood risk management, they are highly dependent on the resources of other actors for the realization of their plans. This fragmented governance setting asks for collaboration and interaction among various actors. The cases show that Dutch actors recognize the need for coordinated action, but as relative outsiders they usually lack the specific knowledge of institutional conditions and social patterns (Gummesson, 2000) to effectively deal with this requirement. This is also why we expected that a projects' effectiveness depends, among others, on the integration of the general knowledge of Dutch experts with the contextspecific knowledge of 'insiders'. As explained in Chapter 4, this includes knowledge about the problem at hand (substantive knowledge), relevant people and networks (political knowledge) and social processes (procedural knowledge) (Leeuwis \& Van den Ban, 2004). In all cases, Romanian counterparts and stakeholders were expected to provide such context-specific knowledge. However, while Romanian actors were in all cases important providers of substantive and procedural knowledge (i.e. they knew about the problems, dilemmas and preferences of various stakeholders and also how to approach and invite various actors), they had limited insight in the wider policy network. Civil servants or NGOs were involved in all cases and asked to identify what actors should be involved. However, these and other Romanian actors often had difficulties identifying critical actors. This was sometimes related to their general lack of understanding of the governance context, but often also to a lack of understanding of how the project with interact with the governance context due to a lack of knowledge about the concept, method or technology being transferred. As explained in Chapter 4, one of the reasons that case B was relatively successful was that it involved Dutch experts who had previously been working in the Romanian context and Romanian experts who had been involved in Dutch-funded projects. As a result, various experts had knowledge on one setting and interactional knowledge on the other setting. This leads us to the conclusion that adequate institutional embedding and diffusion crucially depends on the degree to which actors are able to identify critical actors, which requires that they have an adequate understanding of the actor network. Both Dutch and Romanian actors tend to lack such understanding unless they have relevant project experience. Thus, institutional embedding and a proactive diffusion strategy are 
correlated and depend on the availability of context-specific knowledge. Actors are more likely to have such knowledge when they were previously involved in a similar project.

\section{The role of adaptive management and learning}

In addition, the cases also confirm the need for adaptive management. This criterion is based on the recognition that interventions should be designed as "a flexible process, in which goals and means are continuously adapted to ever-changing circumstances, insights and emerging dynamics" (Leeuwis \& Van den Ban, 2004, p. 54). In a water management context, the term 'adaptive management' is often associated with the capacity of an entire governance structure to take into account new insights and external factors. Social learning that revolves around multi-actor interactive processes plays a key role in developing and enhancing this capacity (Pahl-Wostl, et al., 2010; Pahl-Wostl, et al., 2007b). The degree to which a governance structure supports and facilitates adaptive actions and strategies is also referred to as flexibility (De Boer \& Bressers, 2011). In this thesis, the concept of 'adaptive management' is not associated with the flexibility of a governance structure, but with the capacity of actors to adapt a project on the basis of what they learn during that project.

In Chapter 5, we analysed how social learning influences the outcomes of knowledge transfer projects in more detail. We showed that actors learn through their interactions with other actors. Learning changes the characteristics of actors involved and may lead to the development of immediate (collective) outcomes on which further collaboration can be based. The analysis of case $\mathrm{C}$ shows that interactions contribute to the development of new knowledge, insights and skills in the substantive and the relational domain. For example, the project increased the capacity of Romanian actors to deal with multi-actor problems and their knowledge about potential solutions and the capacity of Dutch actors to implement international projects and their knowledge about the Romanian context. Similar learning processes were reported by actors involved in the other cases: Dutch actors learnt about the Romanian context and Romanian actors learnt about the added value of Dutch knowledge as well as about the Romanian context. In all cases, new insights of Dutch experts led to adaptations in the project (e.g. adjustment of the project scope in case A, the implementation process in case B and the project objective in case C). Despite these adaptive management efforts none of the cases scores very high on adaptive management (see table 7.2). In case A, adaptive management focused on the project scope but not on its institutional embedding. In case B, adaptation was incomplete: FLIWAS was installed at another server but no measures were taken to compensate for this change. In case $\mathrm{C}$, adaptations were made in a rather late stage and involved a considerable reduction of the project outputs.

Thus, in the cases, actors often failed to successfully adapt the project to new insights or changes in external factors. The underlying cause was that the projects were largely designed by experts who had limited knowledge of the governance context or how the 
project would interact with the governance context. Moreover, they were implemented by actors who were often not yet familiar with each other. As a result, local realities often turned out being different than expected. What also played a role is that the projects were implemented in a relatively short period of time and with very limited budget. We concluded in our pilot case study that the possibilities to adapt such projects on the basis of lessons learnt are therefore limited. This does not diminish the role of learning in such projects. Learning (i.e. Dutch actors learning about the Romanian context and Romanian actors learning about what Dutch experts have to offer) is also of crucial importance from the perspective of follow-up (Vinke-de Kruijf, 2009b). When constructive, learning contributes to the development of a basis for further collaboration. However, as Chapter 5 shows, this only applies when actors learn constructive. Learning can also be unconstructive drifting actors further apart and making further collaboration less likely (Vreugdenhil, 2010). This leads us to the conclusion that as projects need to be implemented in a relatively short period of time and with limited funds, the potential to adapt a project to new insights or changing circumstances, and therefore also to improve a single projects' effectiveness on the basis of relational and substantive learning, is limited.

A further analysis of the cases shows that what actors learn in one project can become an important input for another project. For example, the experiences of case A were used in the actor analysis and design of the Dutch-funded project 'Flood plain restoration along the Danube' (2011) and also in the formulation of case C (personal communication). Furthermore, the Dutch-funded project 'Development of a strategy for improved protection against flooding and flood risk reduction along the Timiş River' (2006-2008) formed an important input for case B. Case B did not only build upon knowledge that was developed, but also on existing relations. The Romanian actors involved argued that the good relations that were developed in a previous project were one of the success factors of case $\mathrm{B}$. The same actors also had positive relational experiences in case B and saw the further development of the relations as an important basis for follow-up activities. Dutch actors in case A observed that this also works the other way around: Dutch and Romanian actors should preferably already have developed a working relation in another project. If not, they should develop such relation by spending time with each other. Along similar lines, we noticed in Chapter 4 that when experts do not yet have a common knowledge base, they should spend time with each other to provide relevant background information (Stenmark, 2002). The experiences of the cases further give reason to believe that when actors had positive relational experiences in a previous project, they are likely to experience the same again. In conclusion, substantive and relational learning, when used as input for another project, is likely to have a positive influence on the effectiveness of that project. Actors preferably build upon the positive relational experiences of previous projects or, if this is not possible, they should spend sufficient time with each other. 


\section{Mutual understanding as a basis for constructive interaction}

In the evaluation of the cases, we further assumed that the effectiveness of an interactive process depends on the degree to which actors are able to develop a mutual understanding in communication. Case A shows that language barriers and limited direct interaction inhibit such understanding and that visualization promotes it (see Chapter 3). In Chapter 4, we analysed what kind of interaction means, settings and mechanisms enabled the transfer of knowledge in Case B. The case study demonstrates that international knowledge transfer projects involve actors with diverse socio-cultural, professional and organizational backgrounds (Stenmark, 2002). In such settings, the sharing and acquisition of knowledge benefits from intensive forms of interaction that support the exchange of 'tacit' knowledge (Boh, 2007; Koskinen, et al., 2003). Actors involved in the cases emphasized that they learnt in particular from visualization, (e.g. through the use of an interactive design method, as was done in case A and case C) and field visits (as was done in all cases). Case B further shows that the transfer of knowledge, in particular the development of new knowledge, is enhanced by the collaboration of actors in teams and 'reflection-in-action', which means that actors are given the opportunity to gain concrete experience and to reflect on these experiences (Bresman, et al., 1999; Nonaka, 1994). However, the case also shows that actors with diverse backgrounds, even when they speak the same language and communicate face-to-face, may continue having difficulties to understand each other. The case further gives reason to believe that the development of a mutual understanding depends on interpersonal aspects, including the capacity of actors involved to develop and to maintain personal relations.

The analysis of learning in case $\mathrm{C}$ (Chapter 5) further shows that when actors have problems to understand each other, this may have a negative impact on their motivations. The fact that Dutch actors could not interact directly with their counterparts caused misunderstandings, for example, about the motivations of the Romanian actors. This also contributed to the unconstructive learning that was observed in the case. Thus, while the positive influence of a 'mutual understanding in communication' is hard to prove, the cases show that the absence of mutual understanding in communication has a negative impact on the effectiveness of the cases. The cases confirm that in international settings, intense and direct forms of interaction are of crucial importance to really transfer knowledge. This does not diminish the role of more formal communication settings. Formal meetings play an important role, for example, in the institutional embedding of a project, but are less supportive for the actual transfer of knowledge. In conclusion, mutual understanding in communication promotes constructive interaction and therefore has a positive influence on a projects' effectiveness whereas a lack of mutual understanding has the opposite effect. Because of the diverse backgrounds of actors, the transfer of knowledge in international settings imply that for transferring knowledge actors need intensive and direct forms of interaction and collaboration, translation and visualization. In addition, social and 
personal aspects are likely to contribute to the development of such an understanding, including the capacity of persons to develop and maintain relations.

\section{Relevance of stakeholder involvement}

The evaluation framework assumes that, in order to be effective, interventions should involve relevant stakeholders. Among the pragmatic reasons for involving stakeholders are that it provides access to their knowledge and networks and generates ownership (Leeuwis \& Van den Ban, 2004). In the cases, the inclusion of stakeholder knowledge and perspectives was an important component. However, their involvement had limited, if any, direct influence on follow-up actions and therefore no direct impact on the realization of ultimate outcomes. This does not mean that stakeholder involvement was irrelevant. Their involvement contributed to the development of support, which becomes very relevant when actors move towards implementation. Generally speaking, participatory approaches are better at dealing with uncertainties and ambiguities and therefore preferable when dealing with water management problems (Hommes, 2008). If decision-makers decide to neglect stakeholders, they run the risk of creating superfluous knowledge: a scientifically valid knowledge base that is irrelevant for problem-solving (Van de Riet, 2003). Whether these statements equally apply to different contexts is of course questionable. Apart from substantive reasons, there are other arguments for stakeholder involvement, such as: stakeholders have the moral right and/or duty to participate, the involvement of disadvantaged groups helps to empower or to emancipate them and the involvement of beneficiaries enhances the accountability of a project (Leeuwis \& Van den Ban, 2004). This leads us to the conclusion that the inclusion of stakeholder knowledge and perspectives in $a$ project has no direct impact on the likelihood of follow-up actions but enhances the actual implementation of follow-up actions. Moreover, their involvement may be desirable from an ethical perspective.

\subsection{Discussion}

The evaluation of the cases is based on an evaluation framework that focuses on actors and their interactions. In Chapter 8, we reflect in more detail on the adopted evaluation method. In this section, we reflect on the empirical results of the cases by questioning: did the effectiveness of the cases actually depend on process-related factors? And, what other factors potentially explain the results of the cases?

An important characteristic of the cases is that the transfers were implemented with financial support of Dutch actors. While the proactive efforts of countries to export their 'best practices' may not be coercive, it can be interpreted negative by recipients (Stone, 1999). When projects are only rooted in the desire of actors to export their knowledge, they easily become 'an offer you can't refuse'. Then, the obvious reason for knowledge not being applied is that receiving actors have no interest in the knowledge being transferred. 
This aspect was not explicitly discussed in the cases but was measured through actor motivations and the development of a motivating goal. Based on the data that were collected about actor characteristics, we conclude that the studied transfers were actually wanted by actors of both countries. Case B even directly resulted from a request of one of the Romanian counterparts. While the majority of the project costs were indeed covered by Dutch funds, Romanian actors made considerable contributions in kind (e.g. spend time on the project or provide locations for meetings) showing their willingness concerning the projects. Nevertheless, Dutch actors often reported that their counterparts were much more awaiting and less proactive than they had expected and hoped for. In case C, Dutch experts even started to doubt who actually wanted the transfer. On the basis of the interviews that we had, we have reasons to believe that the Romanian actors were keener to participate than Dutch actors thought. Romanian actors explained that they wanted to learn about new methods and concepts and reported that the projects addressed real problems and matched their policy needs. We have the impression that the observations of Dutch experts are more likely being rooted in misunderstandings than in a lack of interest at the Romanian side. Probably Romanian actors were often not aware what was expected from them. In addition, Romanian actors are generally not used to be proactive, which is a legacy of the communist regime.

Another aspect that may explain differences between cases is the transferability of knowledge. Although there are no studies showing that some types of knowledge are more transferable than others, some argue that this is likely to be the case. Since more abstract knowledge (e.g. rooted in ideas or philosophies) is hard to understand, it is likely to be difficult to transfer. Also very context-specific knowledge that is rooted in very concrete practices (e.g. programmes or organization modes) is more difficult to transfer. Best fit for transfer is probably knowledge associated with techniques, methods or operating rules (OECD, 2001; Stead, 2012). Along similar lines, it is argued that transfers are likely to be more demanding for knowledge concerning the ground rules (constitutional level) or the relations between government actors (policy level) than for knowledge concerning daily activities (operational level). Accordingly, legal systems tend to be more difficult to transfer than practical procedures (De Jong \& Mamadouh, 2002). Generally speaking, the cases concerned the transfer of knowledge associated with concepts, methods or technologies. Thus, they concerned knowledge that was not too abstract or too specific. When looking at specific cases, we see that in case A and C, an 'interactive design method' was successfully applied under supervision of Dutch experts. However, the method was never really transferred, i.e. Romanian experts were not trained to actually apply the method. Nevertheless, the basic ideas underlying the method are used by various Romanian actors in their daily work. The same applies to the concept of integrated water management: it was not transferred but Romanian actors started to integrate some of the principles underlying this concept in their work. Case B concerned the transfer of knowledge associated with a concrete technology. Compared to knowledge concerning methods and 
concepts for more integrated and participatory water management, this knowledge was more easily accepted. However, also in this case the actual application of knowledge requires more integrated ways of working and thinking and was therefore not easy to apply. Thus, the transferability of knowledge that was central in the cases was rather of similar nature. Moreover, the cases show that concepts, methods or technologies are not transferred in isolation but require new ways of thinking and working and are therefore not easy to apply.

An additional factor that may explain the effectiveness of the cases is the degree to which knowledge fitted or was adapted to the receiving context. A comparative study on policy transfer shows that chances on success are higher if actors do not just copy but look for creative integration of transferred knowledge into their own context (Kroesen, et al., 2007). Another study adds that even transfers between similar countries crucially depend on the degree to which knowledge is adapted to national, regional and local factors and needs (De Jong, 2004). Along similar lines, a study on the transfer of best practices in a European context concludes that such processes "are complex and certainly not merely a matter of copying or emulation: successful transfer also involves processes of learning and adaptation" (Stead, 2012 p. 113). In the presented evaluation, adaptive management was included as criterion. However, this criterion measured the degree to which the process rather than the transferred knowledge was modified. This does not mean that knowledge was not adapted. All cases were designed as interactive processes in which actors collaboratively looked for ways to make Dutch knowledge of added value in the Romanian context. As Chapter 6 shows, this process was not without problems in the studied cases. In case A, the 'Room for the River' concept was seen by Romanian actors as an interesting concept but the political and institutional contexts were not yet ready to actually apply the concept. In case B, experts believed that FLIWAS could be of added value but had strong doubts whether the Romanian structural and wider contexts were ready for such tool from an organizational and technological perspective. Case $C$ led actors to the conclusion that the integrated and bottom-up approach that was being transferred was not effective in the Romanian context. Thus, the cases show that receiving actors appreciated the knowledge being transferred but the actual application of knowledge was often difficult. This leads us to two potential, very different, conclusions. On the one hand, the cases support the statement that actors should preferably transfer knowledge that can be adopted easily in their own context. On the other hand, the cases also support the statement that actors should transfer knowledge that is more disturbing and therefore offers more opportunities for learning. The first type of transfer is likely to be more effective but the second type of transfer is likely to have impact at a larger scale. Therefore, to also evaluate knowledge transfer projects on the degree of learning could be an interesting addition to the presented framework. 


\subsection{Conclusions}

This chapter presented a comparative evaluation of three cases. Each of these cases involved different actors and was designed for a specific purpose. However, they were all water projects, with a flood risk management component, that were implemented with Dutch support in Romania. The evaluation shows that none of the cases directly contributed to problem-solving or generated new projects for the Dutch water sector. In all cases, follow-up actions are needed to achieve the desired ultimate outcomes. Collaborative outcomes, which are a joint motivating goal, negotiated knowledge base, mobilization of resources and positive relational experiences, form a necessary basis for the realization of desired ultimate outcomes. Based on the cases, we conclude that necessary follow-up actions get stuck in the absence of an actor who was able and willing to take the lead in the mobilization of (external) resources. When actors have positive relational experiences and develop a negotiated knowledge base, they are more likely to develop such willingness.

We evaluated the process using six process criteria, which are indicators of user engagement. Users refer here to actors with a crucial role in the implementation of the project and follow-up actions. Ideally, crucial actors are engaged in the process, but this is not necessarily the case. The cases show that, in order to be effective, knowledge transfer projects should involve not only actors who are close to the problem but also actors at decision-making positions, who can initiate or promote follow-up actions. We measured this through the criterion of 'institutional embedding'. We found that a project's success depends on the degree to which civil servants and executives, and if necessary also politicians, at the local, regional and national levels are involved and committed. For projects in the public domain, the criterion of institutional embedding partly overlaps with 'proactive diffusion strategy', which measures the degree to which activities are designed and implemented - preferably in an early stage - so that knowledge of the project is feeding back into policy and management practices. The creation of adequate linkages between a project and formal policy processes requires knowledge of the institutional context. Therefore, the successful implementation of knowledge transfer projects also depends on the capacity of actors involved to identify critical actors in the policy network, which is closely related to the 'integration of context-specific knowledge'. Regarding 'adaptive management', we found that a project cannot be adapted easily on the basis of relational and substantive learning. However, when constructive, learning does form an important basis for further collaboration and can form an important input for other projects. The cases further demonstrate that when transferring knowledge in an international setting, the development of a 'mutual understanding in communication' is needed and benefits from relatively intense and direct communication means, translation and visualization. 'Stakeholder involvement' was an important component of the cases. Their involvement does not increase the likelihood of follow-up actions, in which absence the cases got stuck, but becomes highly relevant when follow-up actions are implemented. 
Transfer studies mention several other relevant factors that potentially influence the effectiveness of a knowledge transfer, such as the interest of receiving actors, the type of knowledge being transferred or the fit of knowledge with the context. We briefly discussed the potential influence of these factors. A lack of interest was mentioned by transferring actors, but we found that the projects were, even though they were externally supported, also wanted by the receiving actors. Our comparison of cases further showed that the transferability of knowledge does not explain the differences between the cases. We found that the cases give reason to assume that more innovative knowledge is less likely to be applied on the short term but can have a stronger impact on the long term. Therefore, the relation between 'knowledge fit' and learning is an interesting topic for further research. 


\section{Chapter 8}

\section{Reflection and discussion}

This chapter critically reflects on the theoretical and methodological choices that were made in this research. The first section reflects on our choice to use the Contextual Interaction Theory as conceptual starting-point. Section 8.2 reflects on the adopted evaluation method and approach. Next, section 8.3 discusses the generalizability of the research findings using information collected by other researchers as well as information obtained through ten additional semi-structured interviews. We held these interviews with persons who have been actively involved in the implementation of Dutch-funded international water projects for a considerable period of time (see annex I). The last section provides some concluding remarks concerning the theories and methods used in this research.

\subsection{The Contextual Interaction Theory as conceptual lens}

In this thesis, we used the Contextual Interaction Theory as a starting-point to describe, explain and predict the course and outcomes of knowledge transfer projects. This section reflects on this choice by discussing why this theory was preferred and what we learnt from applying the theory.

\section{The choice of the Contextual Interaction Theory}

Central in this thesis are projects that involve the transfer of knowledge from one country to another. Instead of building directly upon the policy transfer literature, we chose to build upon a policy implementation theory. By doing so, we classified Dutch-funded international water projects as policy processes rather than as policy or knowledge transfer processes. As explained in Chapter 1 and 3, there are good reasons for conceptualizing transfer processes as policy processes. Transfer processes have some distinctive characteristics but are, like regular policy processes, organized around multi-actor problems. Furthermore, policy processes have been studied more extensively than policy transfer processes.

In addition to the Contextual Interaction Theory, other frameworks and models are available for examining the course and outcomes of policy processes. We particularly considered one alternative model, which is a model explaining problem-solving in a network context. This model basically assumes that problems are solved in rounds of 
interaction. This interactive process is shaped by cognitive and social factors which, in turn, are influenced by external developments, institutional factors and network management. Each of these variables offers a possible explanation for the evolution of the process and its outcomes (Koppenjan \& Klijn, 2004). One of the reasons for choosing the Contextual Interaction Theory, instead of this model, was that it attaches more importance to resources. The problem-solving model assumes that resources are part of the network context and therefore only influence the process via cognitive and social aspects. In the studied projects, resources are distributed in a different manner than in regular policy processes. We expected that this would considerably impact the course and outcomes of projects and therefore wanted to include resources as core variable. The use of the Contextual Interaction Theory also had a collaborative advantage. We could work in close collaboration with other scholars of our department, who also use the theory and further develop the theory.

Chapter 3 shows that while the projects under study are multi-actor processes that are similar to regular policy processes, they also have distinctive characteristics: they involve actors of multiple countries and aim at the transfer of policy-relevant knowledge. As explained in Chapter 1, such processes are examined in policy transfer, knowledge transfer and technology transfer studies. In a study on the sharing of water management knowledge between Romania and the Netherlands, knowledge management literature was used as a basis. The author concluded that political and institutional factors had a considerable impact on the projects under study which are not well addressed in the literature on knowledge management (Kort, 2011). Chapter 4 of this thesis shows that this literature stream provides insights in the actual transfer of knowledge but does not explain the overall process and outcomes of a water management project. To understand such projects, the literature on policy transfer is potentially more relevant. To explain why we used the Contextual Interaction Theory as conceptual lens instead of frameworks that can be found in policy transfer literature, we briefly discuss three regularly referred to policy transfer frameworks.

A well-known framework that integrates insights from the literature on lesson-drawing, policy convergence, policy diffusion and policy transfer is the 'Dolowitz \& Marsh' model (Dolowitz \& Marsh, 1996, 2000). In this model, policy transfers are understood as processes by which knowledge developed in one system is used in the development of policies (and the like) in another system. Central in the 'Dolowitz \& Marsh' model are six questions that can be used to study policy transfers: Why do actors engage in the transfer? Who are the key actors involved? What is transferred? From where are lessons drawn? What is the degree of transfer? What restricts or facilitates the transfer? What is the policy impact of the transfer? One of the critiques on 'Dolowitz \& Marsh' model is that it adopts a very general definition of policy transfer, which makes it very difficult to distinguish them from regular policy processes (James \& Lodge, 2003). Besides this, the model is criticized for not paying attention to any of the structural factors that may explain to what degree and why policy transfer has become more widespread. In response to the 'Dolowitz \& Marsh' 
model, (Evans \& Davies, 1999) developed an alternative model that is based on a structure and agency approach. They argue that transfers result from action-oriented intentional learning between distinct organizations. Only if such learning is remarkable, which usually means that it has an international dimension, one should classify it as a policy transfer. Central in 'Evans \& Davies' multi-level model of policy transfer are: (1) the structures and processes at the global, international and transnational level that shape the behaviour of various agents; (2) the impact of changes in economic, technological, ideological and institutional structures at the macro-level; and (3) the network of agents involved in the transfer process at the inter-organizational level. Another critique on the 'Dolowitz \& Marsh' model of policy transfer is that it helps to classify transfer processes but does not include any causal relations that would enhance theory-building. In response to this, (Wolman \& Page, 2002) propose to conceptualize policy transfers as a form of organizational learning and to adopt a communication and information framework that is rooted in information theory. Central in this framework are information networks in which producers, senders, facilitators and recipients transfer information by means of communication, processing, assessing and utilizing information. A study in which this framework was used as a basis, meaning was given to this exchange process by focusing on social interaction between participants of a network and conceptual replication of ideas by participants (De Jong \& Edelenbos, 2007).

Compared to the Contextual Interaction Theory, each of the presented models has its own weaknesses and strengths. The 'Dolowitz \& Marsh' model can be a useful tool when describing and classifying a policy transfer process but does not have any explanatory power. The 'Evans \& Davies' model helps to understand the multi-level context in which processes are embedded but pays less attention to the actual process. Compared to the first two models, the last framework has a rather limited scope: it focuses on cognitive aspects of a transfer and does not help to understand contextual factors. A more general shortcoming of policy transfer studies is that their theoretical underpinning is rather weak. Since transfer processes may not be so different after all, scholars therefore argue that "researchers may be better off using alternative theories focusing more directly on the effects of learning processes or styles of policy-making on policy outcomes" (James \& Lodge, 2003, p. 160) and that "policy transfer analysis alone cannot provide a general explanatory theory of policy change but when combined with other approaches an empirically grounded account of policy change can be developed" (Evans, 2009a). This research confirms these statements by showing that the Contextual Interaction Theory, particularly when combined with insights from the literature on knowledge transfer and management and policy transfer, provides an adequate theoretical basis for explaining knowledge transfer projects. Besides that theory has been applied and tested in a wide variety of environmental policy analyses, the theory also provides a compact analysis framework without diminishing the complexity and importance of policy processes. 


\section{Application of the Contextual Interaction Theory}

In its original form, the Contextual Interaction Theory is a policy implementation theory focusing on two primary actors (target group and implementer) and three variables (motivation, information and power) (Bressers, 2004; Owens, 2008). In this research, we build on more recent versions of the theory in which the characteristics of (multiple) actors are central. In these versions, the names of the three core variables are adjusted to become motives (motivations in a relational setting), cognitions and resources (capacity and power in a relational setting) (Bressers, 2009; De Boer \& Bressers, 2011). Through this research, we developed several new insights regarding the application of the theory. Firstly, we found that the three variables offer a good conceptual lens, but had to be further developed and adapted to match our descriptive purposes. Table 8.1 presents the operational definitions of the three variables that were developed for this research.

Table 8.1 - Operational definitions of the motivations, cognitions and resources of actors involved (adapted from Bressers, 2004, 2009; Owens, 2008; Vinke-de Kruijf, 2011b)

\begin{tabular}{|c|c|}
\hline Variable & Operational definition (for descriptive purposes) \\
\hline Motivation & $\begin{array}{l}\text { - For what reasons does an actor participate in the process or consider } \\
\text { participation in follow-up actions? Potential sources of motivation include: } \\
\text { - Own objectives: the process contributes to the realization of the personal or } \\
\text { organizational objectives of an actor; } \\
\text { - External pressure: an actor regards it as its civic duty or has financial, social or } \\
\text { political reasons to participate } \\
\text { - Self-effectiveness assessment: an actor believes that it is within its capacity to } \\
\text { contribute to the project or that the project will contribute to its capacity. }\end{array}$ \\
\hline Cognition & $\begin{array}{l}\text { What information associated with the process or follow-up actions does an } \\
\text { actor believe to be true? Cognitions are interpretations about: } \\
\text { - The problem (its nature, meaning and urgency) and potential solutions } \\
\text { - The relevance and potential of the process in dealing with particular problems, } \\
\text { including possibilities for follow-up }\end{array}$ \\
\hline Resources & $\begin{array}{l}\text { - What resources are contributed by and attributed to actors that are needed to } \\
\text { implement the process or follow-up actions? Relevant resources include: } \\
\text { - } \quad \text { Human resources: quality and quantity of manpower } \\
\text { - } \quad \text { Knowledge: information and expertise (know-how) } \\
\text { - } \quad \text { Money: financial resources } \\
\text { - Institutional resources: formal and informal power to get things done }\end{array}$ \\
\hline
\end{tabular}

Furthermore, we found that an analysis of actor characteristics provides a deeper understanding of the process, but is of limited use if not complemented with descriptions of the process and its context. More specific, process descriptions preferably start with a more general introduction of: the history and context (physical, administrative and policy); the objectives, activities and actors involved; and the interactive process and its results. Thirdly, the two-actor version of the theory is less applicable to knowledge transfer 
settings. In regular policy processes, the interactive process can be explained in many cases by focusing on two actor coalitions. This does not apply to transfer processes since they involve external actors who have completely different characteristics than the target group and the implementers of a policy process. Fourthly, we found that to understand how actor characteristics change over time, a researcher preferably includes descriptions about the mutual relations between actors. Such descriptions pay attention to questions, such as: Did actors already know each other? How did they experience the collaboration? Are they willing to continue the collaboration?

To predict the achievement of desired outcomes, we especially built on the probabilistic predictive part of the Contextual Interaction Theory. This part of the theory predicts what type of interaction (e.g. active or passive cooperation, opposition or obstruction) is to be expected in relation to the implementation or application of a policy or policy instrument. These predictions are made based on the motivations of the target group and implementer, the availability of information and the power balance (Bressers, 2004; Owens, 2008). Since our cases clearly had a multi-actor setting, the predictive model that was developed for a simplified two-actor setting could not be applied directly. However, we could use the same starting-point, which is that the implementation of any task depends on the existence of a motivating goal, the requisite knowledge base and resources (capacity and power) (Bressers, 2004). Next, we used insights from the literature on policy processes in developing a multi-actor model. This literature shows that, in network settings, resources are spread among multiple actors with diverging interests and perceptions of reality (Van de Riet, 2003). This implies that resources can only be mobilized by pooling them, which is only likely if resourceful actors develop a goal that motivates them all and reach an agreement about the meaning, validity and significance of certain knowledge (Hommes, et al., 2009b; Koppenjan \& Klijn, 2004). We further took up the idea that constructive interactions contribute to the development of a collective resource: trust (Bressers, 2009). This resulted in a set of four immediate (collective) outcomes that may result from interactive processes and form a basis for the realization of ultimate outcomes: the development of a joint motivating goal, the creation of a negotiated knowledge base, the mobilization of necessary resources (by pooling them, if necessary) and positive relational experiences (as a basis for trust) (see Chapter 3). These criteria thus help to predict the outcomes of multi-actor processes when interactions have taken place, but the final outcomes are not yet visible. Compared to the predictions that can be made using the twoactor model, the multi-actor model is limited: it focuses on whether a process is likely to result in active cooperation but does not predict other types of interaction, such as learning or opposition.

In previous studies, the three variables of the Contextual Interaction Theory were primarily used to explain or to predict the course and outcomes of an interaction process. A suggestion that was made for further research is to elaborate the dynamic interaction between core actors: How are actor characteristics shaped by the process? What is the role 
of learning in this? (Owens, 2008). To further elaborate the role of learning is of particular relevance when analysing transfer processes, since learning plays an important role in the transfer of knowledge (Evans \& Davies, 1999; Stead, 2012; Wolman \& Page, 2002). To understand how actor characteristics are shaped by the process, we built upon insights from the literature on social learning (see Chapter 5). This literature shows that learning in interaction with other actors involves an increase of knowledge, insights and skills in the substantive domain and/or in the relational domain (Huitema, et al., 2010; Pahl-Wostl, et al., 2007a). This may contribute to outcomes at the individual level (e.g. new knowledge) as well as the collective level (e.g. trust or shared ideas) (De Laat \& Simons, 2002; Gerlak \& Heikkila, 2011; Newig, et al., 2010). We connected these learning processes to the Contextual Interaction Theory by arguing that learning involves changes in (individual) motivations, cognitions and resources and may contribute to the development of immediate (collective) outcomes. While social learning literature often assumes that learning promotes further collaboration, we found that this is not necessarily the case. Interaction and learning can be constructive contributing to the development of collective outcomes, but also be unconstructive drifting actors further apart (Vreugdenhil, 2010). This confirms the idea that only well-functioning partnerships result in mutual adjustment: actors tend to start acting from a set of consistent values, using a common reference frame and concentrating on their relative strength (Bressers, 2009). Thus, we elaborated the dynamic part of the Contextual Interaction Theory by explaining changes in actor characteristics in terms of social learning.

The Contextual Interaction Theory asserts that contextual factors only influence the course and outcomes of a process insofar they influence the characteristics of core actors. One of the suggestions for further research is to elaborate how contextual factors influence actor characteristics (Owens, 2008). In this research, we particularly tried to develop a better understanding of how an international context influences a policy process. We showed that such a context implies that a process involves one group of actors who is used to work and live in a different wider and structural context than another group of actors. Chapter 4 shows that this has an impact on the interactive process: actors with diverse knowledge backgrounds tend to have more difficulties to understand each other (Stenmark, 2002). Chapter 6 shows that this also has an impact on actor characteristics: actors with more diverse backgrounds tend to have more diverse motivations, cognitions and resources. In Chapter 6, we also studied the embedding of the process in the structural and wider context of the receiving country. The findings of this and other chapters show that the realization of desired outcomes crucially depends on the embedding of a project in the structural (institutional) context and - to a lesser degree - also in the wider context. The effective application of knowledge requires that projects involve not only actors who are affected by a problem but also of actors who are in the position to mobilize (external) resources. This research thus shows that the outcomes of a process depend not only on the (changing) characteristics of the actors involved but also on the characteristics of actors who need to be involved since they have a crucial role in the realization of the outcomes. Therefore, to 
explain and successfully implement a policy process, practitioners and researchers need to know who the critical actors are in a certain process. Hence, an adequate understanding of the structural context is indispensable when examining or implementing a policy process.

\subsection{Evaluation method and approach}

This research aimed not only at explaining the course and outcomes of the projects under study, but also at evaluating them. Any evaluation, including ours, is partial. In this section, we elaborate the partiality of our evaluation and discuss some alternative approaches. We further explicitly reflect on the use of real-time case studies in evaluation research.

\section{Scope and partiality of the evaluation}

The purpose of our evaluation was to distinguish effective from less effective knowledge transfer projects, which we conceptualized as interventions. We chose to focus on the effectiveness of the intervention process and its outcomes implying that we did not question the need, design or efficiency of the intervention (Rossi, et al., 2004). We defined effectiveness as the degree to which an intervention contributes to the achievement of intended or desired outcomes (Scriven, 1991). To evaluate interventions in terms of 'goal attainment' used to be common practice in evaluation research but has lost popularity. The research attention has shifted towards quality assurance implying that evaluations increasingly focus on individual processes and outcomes and rely more on expert judgements for the measurement of effectiveness (Patton, 2002). This trend is also reflected in the literature on network and process management, in which scholars argue that process criteria, such as, a fair process, actor contentment, the degree to which learning occurred, the development of relationships or problem solving are more appropriate evaluation criteria than goal achievement (de Bruijn \& Ten Heuvelhof, 2008). Also in the strategic planning literature, scholars argue that evaluations should question performance - i.e. did the planning process improve the quality of the decision process - rather than conformance between plan and final outcomes (Faludi \& Altes, 1994). We agree with these scholars that the attainment of project goals does not provide much insight in the quality of the process. At the same time, we argue that it does not make sense either to focus only on process or actor-specific criteria (see also Chapter 3). We therefore looked for an evaluation method that holds a middle position between goal and process evaluation and decided to concentrate on the actual purpose behind an intervention as well as on the actor characteristics that contribute to the realization of this purpose. The actual purpose of an intervention can be traced by analysing its context and is reflected, for example, in the policy of a government, an organization or an (international) institution. Compared to the evaluation of actor-specific and project-specific goals, the evaluation of 'meta-level' objectives has two major advantages: (1) they are more likely to remain stable over a longer period of time; and (2) using them enables the comparison of similar processes. 
In search for the actual purpose of Dutch-funded projects in Romania, we decided to take the Dutch perspective on these projects - as reflected in recent national policies on international water management - as starting-point. These policies read that the Dutch government supports international water management in order to: (1) contribute to the solving of water-related problems (in benefiting countries); and (2) generate new projects for the Dutch water sector (Min V\&W, 2007, 2009). While both goals are important to the Dutch government, they are not equally important for various programmes, projects and actors. In the 'Partners for Water' programme this 'double-goal' has always been leading. However, in development aid programmes this double-goal only gained importance in recent years. Furthermore, 'problem-solving' is likely to be an important driver behind any water project, but the generation of new projects is not necessarily relevant for actors of the benefiting country and also not as important for Dutch governmental organizations. Moreover, Dutch actors have additional reasons for engaging in international water projects. For example, non-governmental organizations often aim at poverty reduction and empowerment, water boards and water companies want to acquire knowledge and be an attractive employer and actors of the benefiting country may want to strengthen their position. These and other actor-specific goals were not taken into account in this research.

Our evaluation was also partial in the sense that it focused on the verification of policy objectives. A possible extension would be to question also the relevance of these objectives in the given situation (Fischer, 1995). We do not systematically reflect upon this question in this thesis. However, we already showed that the double-goal is not equally relevant in all contexts. We will also touch upon the relevance of this double-goal when discussing the practical implications of this research (section 9.3). Evaluations can become even more indepth by including second-order evaluation questions about the value of the policy objectives to society and the kind of social values a policy should contribute to (Fischer, 1995). One of the reasons that such questions are not reflected upon in this research is that we believe that they are better answered by policy makers. However, we do hope that the findings of this research encourages policy makers to reflect on the relevance of the policy goals that we evaluated as well as the value of these policy goals to society.

\section{Selection and application of the evaluation criteria}

Compared to other scholarly evaluations, our evaluation has a very applied and practical focus. This closely relates to the chosen research strategy in which the development of practical knowledge for the water management domain was central (see section 1.4). One of the implications is that the ultimate outcome criteria are specific for the evaluation of Dutch-funded projects. Also the formulated process criteria are rather specific and unlikely to be equally relevant for other policy processes. For example, the inclusion of a proactive diffusion strategy is very relevant for pilot projects but less relevant for regular water projects. Such limitations do not apply to the immediate outcome criteria, they are of more general nature and potentially relevant for the evaluation of any policy process. 
Furthermore, the adopted approach is of added value to many types of evaluations. This research shows that the identification of 'meta-level' goals helps a researcher in developing practical knowledge. Furthermore, this research confirms that evaluations become more useful when they also reflect upon the process and its immediate outcomes. Such criteria help to explain the realization of ultimate outcomes (and therefore provide a basis for practical recommendations) and also to predict the realization of ultimate outcomes if they are not yet visible.

The outcome criteria that were developed in this study are case-specific and related to the Contextual Interaction Theory. Nevertheless, they are similar to criteria that are used in other studies focusing on the evaluation of collaborative environmental projects. They basically acknowledge that such projects have environmental outcomes (reflected in the criterion of 'problem-solving' in our case) and social outcomes (reflected in the immediate outcome criteria). In addition, an evaluator may consider also the production of tangible products or outputs, for example, in the form of a concrete plan or document (cf. Innes \& Booher, 1999; Koontz \& Thomas, 2006; Mandarano, 2008). The inclusion of such concrete products could be a useful addition to the evaluation model that we developed.

For researchers who need to evaluate programmes with less concrete and measurable outcomes the proposed evaluation approach may not be feasible. If this is the case, researchers may be better off using the concept of receptivity that focuses on the receptiveness of the sender and receiver to information. The concept of receptivity emerged from technology transfer literature (Seaton \& Cordey-Hayes, 1993; Trott, et al., 1995) and was later used in the evaluation of water policy instruments (Jeffrey \& Seaton, 2004) and water knowledge and innovation programmes (Bressers, 2011). The concept of receptivity could also be a useful addition to the developed evaluation model. The concept could, for example, provide a better understanding of the criterion 'mutual understanding in communication'.

This evaluation research forms an important addition to the literature on policy transfers, which generally pays little attention to the evaluation of transfer processes. Various scholars acknowledge this weakness in the transfer literature stream and came up with suggestions (cf. Dolowitz \& Marsh, 2000; Marsden \& Stead, 2011). One of these suggestions is to assess effectiveness as the degree to which a process contributes to the realization of policy objectives (ultimate outcomes in our evaluation model) or is perceived as a success by key actors involved (an aspect that was consciously left out of our evaluation model). Such assessment could be complemented with an analysis of the following process factors: the availability of information, the completeness of the transfer and the attention that is paid to contextual differences (Dolowitz \& Marsh, 2000). Such assessment helps to understand why knowledge has been transferred or not, but does not shed much light on the interactive process and the process' connections to formal policy processes. The presented comparative evaluation (Chapter 7) shows that such factors 
actually have considerable impact on the effectiveness of a transfer process. Another suggestion is to evaluate the outcomes of a transfer process in terms of policy-oriented learning which may occur in various stages of a decision-making process. Learning includes here the application of knowledge and thus involves actual changes in the setting, the use or goals of policy instruments (Evans, 2009b). Along similar lines, scholars argue that policy transfer evaluations should really demonstrate the knowledge transfer. In other words, evaluations should verify whether knowledge being transferred is actually reflected in the design or implementation of the policy under concern (Marsden \& Stead, 2011). These suggestions are very much reflected in the developed evaluation framework, which adds to this suggestion by including an evaluation of the process and its immediate outcomes. Thus, this research adds to existing policy transfer literature by presenting and applying an evaluation framework that includes explanations.

\section{Real time case study research as strategy}

As Chapter 1 explains, this research aims at developing practical knowledge for the water management domain. Being involved in real knowledge transfer processes allows a researcher to gain concrete experience and therefore contributes to the development of such knowledge (Flyvbjerg, 2001). Real time case study research has some important advantages, but also imply that the process and its outcomes are unknown when selecting a case (Van de Ven, 2007). For the projects under study, it was often even unclear whether desired outcomes would be achieved. This limitation was dealt with by evaluating the case studies also in terms of immediate outcomes. Still, the actual effectiveness of all three cases remains unknown, implying that we cannot draw final conclusions on the relation between the immediate and ultimate outcomes (Chapter 7). Therefore, a valuable addition to this research would be to evaluate the same projects again in a few years. Such an evaluation was actually carried out within the context of another research project called 'Evaluation of the Ciobarciu Wetland Project: Analysis of long-term impact' (Cornelissen, 2011). Before reflecting on the outcomes of this evaluation, we shortly introduce the studied project.

Like the selected cases, the Ciobarciu Wetland Project was implemented in collaboration between Dutch and Romanian actors and financially supported through a Dutch (preaccession) programme. The projects' main beneficiary was a regional water authority in the Northeast of Romania. In the short term, the project aimed at realizing a wetland including a management plan, providing the Romanian beneficiary with knowledge and experience in the fields of ecological restoration, interactive planning and stakeholder participation, creating partnerships between regional actors with a role in environmental management and sharing the project experiences with other regional water authorities. In addition, the project had several long term objectives which were to make a contribution to the creation of a network of wetlands (a 'string of pearls') in the river basin, the integration of nature and water policies, the implementation of the EU Water Framework Directive, the development 
of environmental NGOs and the strengthening of environmental education. The project was implemented between 2003 and 2006.

The realization of the project's short term and long term objectives was evaluated by the project team just after project completion and by a researcher in the summer of 2011. The last evaluation shows that evaluators face just as many, if not more, problems in evaluating a project after a period of five years as they do directly after project completion. What complicated the last evaluation was that various actors attached different meanings to the formulated objectives. For example, various actors had very different ideas about whether the wetland and its management plan were successfully realized. Romanian actors defined three guidelines that were formulated during the project as a management plan whereas Dutch actors perceived these guidelines as a basis for the further development of a management plan. Another problem faced by any evaluator is that evaluations are just snapshots in time. At the end of the project and five years later, the wetland was functioning well but in between it had not been functioning for a period of two years due to construction works. The absence of water in this period had been a disaster for the biodiversity of the area. Furthermore, also after several years the realization of some objectives appeared to be just as uncertain as it was after project completion. For example, after five years the beneficiary had some ideas for the creation of other wetlands but was still unable to mobilize financial resources for the realization of these ideas.

Compared to an evaluation after project completion, an evaluation after a few years has the advantage that it also provides insights in how outcomes developed over the past few years. Therefore, one may expect that such evaluations also provide more insight in the realization of ultimate outcomes, which are typically of greatest importance. However, these are also the outcomes on which an intervention has less direct influence since such outcomes are also influenced by many other factors (Rossi, et al., 2004). In other words, after a period of time it also becomes more difficult to distinguish between the effects of an intervention and the effects of other processes. In the case of the Ciobarciu Wetland Project, some of the outcomes could not be attributed easily to the project. Observed outcomes included, for example, the improved cooperation between the regional water authority and other actors, the development of ideas for additional wetlands and the existence of courses on ecological restoration at the university. Some of these outcomes may have resulted partly from the project but were certainly also the result of other factors, such as the implementation of EU directives.

Thus, evaluations that are executed after a period of time may provide additional insights in the realization of ultimate outcomes. However, it also becomes more difficult to attribute observed changes to the intervention. Based on our own research, we argue that many of the potential effects of an intervention are already visible at the end of a project. The underlying reason is that only when actors start applying certain methods or concepts shortly after project completion, they are likely to continue using them. When no further 
actions are undertaken, actors will maybe remember some interesting ideas but with no result. The more time passes after a project, the less likely actors are to undertake follow-up actions.

\subsection{Generalizability of the case study results}

As explained in Chapter 1, we deliberately chose to limit the research scope to a limited number of cases that concern the transfer of knowledge between the same two countries. By doing so, we were able to gain an in-depth understanding of the case studies and also to compare the case study results (Chapters 6 and 7). Comparison of the cases allowed us to arrive at more general insights about the effectiveness of Dutch-funded projects in Romania. We are confident that the theoretical concepts that are introduced in this research also apply to other knowledge transfer projects. However, not all factors that we identified are equally relevant for other projects. This section therefore reflects on the representativeness of the cases and questions the degree to which our research results apply to a broader population of cases (Gerring, 2006). In doing so, we distinguish between three different populations: (1) Dutch-funded water projects in general (including projects that are focusing on other water problems); (2) Dutch-funded water projects in other countries; and (3) knowledge transfer projects that are implemented with other funds or initiated for other reasons. In discussing the generalizability of our results to these populations, we build upon the results of related research projects, expert opinion and literature.

\section{Export of knowledge about water management and water services}

Central in this thesis are projects in the flood risk management domain. The Dutch water sector is highly valued and well-known for its expertise in this domain. For example, experts of the United States asked for assistance from Dutch experts after the hurricane Katrina floods in New Orleans. While flood risk management is a core expertise of the Dutch water sector, the sector encompasses a wide range of knowledge domains. These knowledge domains are promoted as delta technology and water technology. Delta technology concerns expertise that is associated with living on the interface between land and water. It includes knowledge about hydraulic engineering, flood protection, port development, coastal zone management and dredging. Water technology refers to knowledge about water services including drinking water, wastewater treatment and sanitation. In addition, the Dutch water sector is active in other fields, such as irrigation (Hameeteman, et al., 2008). This diversity is reflected, for example, in the wide range of topics that were covered by 'Partners for Water' projects between 2005 and 2010 (Partners voor Water, 2008, 2012a). Thus, Dutch-funded international water projects concern many different topics; flood risk management is only one of them.

Chapter 1 explains that one of the reasons for focusing on flood risk projects is that problems in the water management domain tend to be more complex than, for example, 
problems in the water services sector. As explained in Chapter 2, flood risk governance tends to cut across boundaries of various sectors and territories. In the case of Romania, it does not only involve organizations that are subordinated to the Ministry of Environment but also organizations that are subordinated to the Ministries of Agriculture and Interior. Furthermore, as the country is located in an international river basin and being a member state of the EU, flood risk governance is also influenced by international and supranational organizations. Many of the flood risk problems in Romania are rooted in the failing capacity of the government to adequately connect these different elements. This governance structure also impacted the case studies. In all cases, the integration of different sectors and governance levels was perceived as a necessary step in the solving of flood risk problems. As explained in Chapter 6, fragmented governance especially had a negative impact on the process and outcomes of case A and case C. We never explicitly compared flood risk management projects with other water management projects. However, there is no reason to expect that the existence of a complex governance structure is a unique feature of flood risk management. Any water management project - whether it addresses ground water, water quality or ecological issues - is likely to be affected by problems associated with fragmented governance.

In Romania, the Dutch water sector is not only active in the water management sector but also in the water services sector. Like flood risk projects, drinking water and wastewater projects are affected by fragmented governance. A study of 2009 shows that the localfocused governance structure that emerged after the fall of its communist regime was incoherent and causing major problems in the delivery of water services. Romania's EU accession was an important trigger to change this structure and to start a regionalization process. The implementation of reforms was and is on-going and not without problems. However, the proposed changes are expected to create a more coherent governance structure and to improve the delivery of water services in Romania (Vinke-de Kruijf, et al., 2009). A comparison between the reforms of this sector and the flood risk sector shows that similar changes were made in both sectors. However, the creation of a more coherent governance structure is more challenging in the flood risk sector since resources, and especially property rights, are much more fragmented. This means that the need for deliberate collaboration efforts among various actors is relatively higher (Vinke-de Kruijf, et al., 2013).

Experts of the Dutch water sector confirmed that water management projects differ from water services projects. Whereas governments are often the main beneficiary of delta technology projects (with the exception of dredging and port development projects, which often also involve the private sector), water companies and industry are the main beneficiaries of water technology projects. This implies that governance issues play a more prominent role in the export of delta technology and technology and organizational issues in the export of water technology. At the same time, these differences are not that prominent in all projects: flood risk projects often also involve the transfer of innovative 
technologies (e.g. decision-support systems or dike strengthening products) and water services projects often touch upon governance issues. The latter applies, for example, to projects that are implemented against the background of privatization and scaling up of public water companies. The transformation of public water companies into commercial organizations with public shareholders is currently going on in many countries (among others in Eastern Europe and Asia). These processes are often supported by international financing institutes as well as by Dutch water companies. These companies support these processes through the provision of knowledge and finances. However, they differ from the studied projects, since support is given on a partnership base rather than a project base. In projects, such as the cases in this thesis, direct interaction and communication between actors is usually limited to international missions and visits. Partnerships are typically established for a period of several years (like the partnership that was initiated by actors involved in case C). The two largest Dutch water companies (Vitens and Evides) are very active in forming partnerships. Compared to Dutch-funded projects, these partnerships are much longer and much more intense. Only for the analysis of problems and needs, Dutch actors already take several months. And, when a partnership is signed, a Dutch expert moves to the benefiting country to collaborate directly with the managers of the benefiting water company. Hence, problems associated with the development of a 'mutual understanding in communication' play a role in the beginning of the partnership but will gradually diminish. Furthermore, the generation of follow-up projects for the Dutch water sector is not among the ultimate objectives of such partnerships. Therefore, the criteria of institutional embedding and pro-active diffusion strategy contribute to the success of partnerships, but have less influence on their effectiveness.

An important difference between partnerships and projects is that Dutch organizations commit themselves for a longer period of time to a partnership. Several Dutch experts mentioned that such commitment is a key factor in the realization of ultimate outcomes. In order to be successful, it is important that organizations are not only interested in the implementation of a project but also have strategic objectives like the acquisition of a market position or long term collaboration. The results of case $\mathrm{A}$ and case $\mathrm{C}$ show that this does not necessarily apply to projects. Therefore, partnerships are said to be relatively more successful. However, Kort (2011) shows in an evaluation of five drinking water projects in Romania, which were implemented within the context of a partnership, that partnerships are not always more successful. The problem in this collaboration was that most of the Dutch experts were only involved on a project base. Dutch actors were skilled and committed but usually visited their counterparts only a few times for a period of several days. The evaluation shows that actors of both countries often failed to overcome mutual differences and to develop a shared vision and insights. Regular misunderstandings had a negative impact on the development of mutual trust and limited learning occurred. What further complicated collaboration were the hierarchical and dependency relations between the wide 
variety of (mostly public) organizations involved and, especially at the Romanian side, also within these organizations.

The presented discussion shows that the structural context of water services projects may be different but is not necessarily less complex than the structural context of water management projects. Our research findings are therefore likely to equally apply to most other Dutch-funded water projects. We are less confident that all elements of the developed evaluation framework are equally relevant for projects that primarily involve the private sector (like harbour and dredging projects) or for intense partnerships that run for a longer period of time.

\section{Export to countries around the world}

This thesis concentrates on projects that are implemented in Romania. In addition, the Dutch water sector is actively involved in a wide variety of other countries around the world. For example, within the context of 'Global Water', partnerships are developed with five delta countries: Bangladesh, Egypt, Indonesia, Mozambique and Vietnam (Min V\&W, 2009) and within the context of 'Water for Development' bilateral relations are developed with the following developing countries: Benin, Ghana, Kenya, Mali, Rwanda and South Sudan (Knapen, 2012). In this subsection, we reflect on the generalizability of our results to these different countries.

As explained in Chapter 6, there are considerable contextual differences between the Netherlands and Romania implying that Dutch actors had other motivations, cognitions and resources than Romanian actors. Contextual differences between both countries help to understand why Dutch actors were motivated to share and Romanian actors to acquire knowledge. These differences also explain differences in cognitions and resources, which made that actors sometimes had difficulties to understand each other. In our research, we did not investigate projects that were implemented in other countries. However, (Peters, 2012) used the developed framework for the evaluation of the Dutch-funded 'Banger pilot polder project in Semarang, Indonesia'. Before comparing the results of this study with our own findings, we shortly introduce the project.

Like in the cases that were examined in this thesis, the reduction of flood risks was central in the Banger polder project. The project area experiences urban floods due to heavy rainfall on a regular basis. In addition, tidal floods occur on a daily basis. The underlying causes include land subsidence, a reduction of unpaved surface and poorly functioning drainage systems. To reduce the occurrence of floods, the Dutch proposed to transform the area into a polder. This means that the area is closed off from the sea and that the water level is artificially controlled. Furthermore, an organization for the operation and maintenance of the polder is to be established. The development of the studied project was one of the outcomes of the Memorandum of Understanding that was signed between two Dutch and two Indonesian ministries in 2001. Following discussions between Dutch and 
Indonesian actors, the City of Semarang was selected as location for a pilot project. In 2003 and 2004, a feasibility study was executed in collaboration between various Dutch and Indonesian organizations and with financial support of 'Partners for Water'. Based on this study, an area along the Banger River in Semarang was selected as location for a polder. In 2006, 'Partners for Water' approved a proposal for the preparation of a technical design (2007-2009). Around the same period, a Dutch regional water board started to coordinate the establishment of a 'polder board'. This project was financially supported by the Association of Netherlands Municipalities. Since 2010, the board is in place. The construction works, which started in 2010 and were recently resumed, were also implemented partly with Dutch financial support.

In 2011, our evaluation framework was used to assess the process and outcomes of the technical and institutional components of the polder project. While it is yet unknown whether the project will indeed contribute to problem-solving and follow-up projects (this highly depends on the functioning of the polder board), such outcomes are likely to be achieved. The implementation of the project was spread over a considerable period of time and involved a wide variety of actors. The development of a joint motivating goal, a negotiated knowledge base and the mobilization of resources was a long process but with good results. Furthermore, positive relational experiences and the development of mutual trust were created and formed an important basis for follow-up actions. The process criteria helped to explain the course and outcomes of the process. The case study especially highlights the importance of engagement: actors who were less involved in the process were more often contesting the knowledge base. The case study further illustrates that mutual understanding in communication benefits from the involvement of actors with interactional knowledge and tends to increase over the course of time. The case study confirms the importance of institutional embedding and that such embedding benefits from the active involvement of officials at decision-making positions (Peters, 2012).

This Indonesian case study shows that the evaluation framework and related findings apply not only to Dutch-funded projects in Romania but also to Indonesia. At the same time, the case study and expert interviews also highlight important differences regarding the Dutch relation with these countries. First of all, the bilateral relations between the Netherlands with Indonesia are much stronger than those with Romania. This implies that, compared to Romania, the institutional embedding of projects is easier since: (1) there are stronger connections between actors of both countries at high positions implying that it is easier to actively involve crucial actors of the benefiting country; and (2) there are more actors with interactional knowledge: many Dutch water managers participated in Indonesian projects before and many Indonesians had a few years of education in the Netherlands. Another difference between Romania and Indonesia is that other financial resources are available for follow-up actions. As explained in Chapter 7, the realization of follow-up actions in Romania highly depends on national and European funds. Next to 'Partners for Water', there are very few Dutch financing instruments left supporting water projects in Romania. 
For water projects in Indonesia as well as some other Asian, African and South American countries, a much wider variety of Dutch funds is available (see Section 1.1). Furthermore, in Indonesia and other developing countries international financing institutions, such as the World Bank or the Asian Development Bank, are much more active. According to Dutch experts, these institutions often appreciate the Dutch way of working and therefore involve them in projects. In addition, the Dutch government policies increasingly focus on specific delta or developing countries (see Section 1.1), which does not include Romania. On the basis of the Indonesian experiences and expert interviews, we expect that projects are relatively more successful in countries with which the Netherlands has strong bilateral relations and for which more international and Dutch funds are available. In such countries, financial support for follow-up actions is easier to access, increasing the likelihood of projects to be effective.

The previous discussion shows that Dutch-funded projects are likely to be less successful in Romania than in some other countries. However, there are also reasons to expect the opposite being the case. An important reason could be that the Netherlands and Romania are relatively more similar since they are both European countries. In Europe, national water management policies are heavily influenced by European legislation, such as the Floods Directive and the Water Framework Directive. Also in other domains, such as spatial planning, new EU member states start focusing on similar issues as Western Europe. Nevertheless, important differences remain between old and new member states, including a lower level of trust in government and a shorter history and weaker position of spatial planning. Moreover, European countries differ considerably in social, economic and institutional terms (Stead, 2012). Still, the differences between two European countries (e.g. the Netherlands and Romania) are smaller than they are between countries of two different continents (e.g. the Netherlands and Indonesia). One would therefore expect that a knowledge transfer between two European countries is relatively easier. Some authors have questioned this and found that transfers between similar countries are not necessarily more successful than transfers between more dissimilar countries. In practice, smaller institutional and practical differences are easier overlooked than larger legal, cultural and political differences (De Jong et al., 2002b; Kroesen, et al., 2007). Moreover Chapter 6 shows that the success of a transfer especially depends on whether there is a strong coalition of support in the benefiting country (De Jong, 2004). No matter what type of transfer, such coalition needs to be created: Dutch-funded project are unlikely to be implemented without support of benefiting actors. However, since they are paid for by the Netherlands, they usually fall outside formal decision processes, even though they are often in line with changes that are desired by supranational and international institutions, like the European Commission or the World Bank. Thus, the degree to which a country differs from the Netherlands is unlikely to be directly related to the effectiveness of a knowledge transfer project. In fact, actor-specific characteristics have much more explanatory power. 
Nevertheless, contextual differences may affect the success of a knowledge transfer. Chapters 4 and 6 illustrate that knowledge transfers involve actors with diverse backgrounds and knowledge levels. We found that actors with interactional knowledge can help to overcome differences between actors. The involvement of such actors is important in any knowledge transfer project, but probably becomes even more important in countries that differ relatively more from the Netherlands. The relative importance of such a difference can be questioned. For example, Dutch experts often mentioned that Romanian experts had a relatively high level of technical knowledge compared to actors of less developed countries. However, this did not directly ease the projects since actors still had difficulties to understand and to apply Dutch knowledge. Thus, no matter the countries involved, knowledge transfers are by definition processes of learning and adaptation (Stead, 2012).

On the basis of literature and the experiences of the Indonesian case study, we expect that the evaluation framework equally applies to Dutch-funded projects in other countries. Practitioners who have been active in many different countries confirm that while institutional contexts differ considerably, similar problems and issues occur in knowledge transfer projects. This does not mean that there are no differences. While the factors that explain the effectiveness of Dutch-funded projects are largely the same, the actual effectiveness of projects in other countries may be different. In some countries there are, for example, better accessible funds for the realization of follow-up actions than in other countries. The functioning of bilateral relationships may also vary over the course of time. For example, bilateral relations between the Netherlands and Romania recently cooled down considerably because of the Dutch perspective on Romania's integration into the EU. Experts also noted that it takes, for example, in Asian countries more effort to build relations. If this is the case, the involvement of actors with interactional knowledge is likely to be relatively more important.

\section{Knowledge transfer projects funded by other countries or initiated for other reasons}

The studied cases are examples of knowledge transfer projects that are implemented with financial support of a country that is very proactive in spreading and exporting knowledge. Such projects are not necessarily examples of coercive transfers but they tend to involve elements of persuasion and learning (Stone, 1999). The cases concern the Dutch-funded projects but the findings of this research are likely to apply to water projects that are supported by other countries as well. They are particularly relevant for countries that are also proactively exporting their knowledge to less developed countries. In particular Germany and Scandinavian countries are, like the Netherlands, focused on strengthening the economic position of their country as well as to really contribute to the solving of global water problems and other altruistic goals like poverty reduction. Also countries like the United States, Japan and France are very active in spreading their knowledge. What distinguishes their approach is that geopolitical motives play an important role in the 
selection of beneficiaries. Furthermore, they often have a more technical focus. For example, simultaneously to the Banger project in Indonesia, a similar project was implemented with the support of Japanese experts and a Japanese loan. Compared to the Dutch-funded project, the Japanese project had a more complex technical design and was expected to be more difficult to maintain (Peters, 2012). What all these projects have in common is that they are driven by a desire to achieve certain goals through the export of knowledge, which makes that they are similar to the cases studied in this thesis.

The studied cases differ from projects that are funded by the European Commission or by other international financing institutions. Generally, the studied cases focus more on innovation and have a shorter duration. They are examples of pilot projects in which actors can experiment with innovative approaches at the micro-level of individual actors and local practices. Such pilots can function as catalyst in the transition of a country, for example, towards more integrated, participatory or adaptive water management practices. However, such transition often also involves changes at the structural context (meso or regime) level and the wider context (landscape or macro) level. The structural context usually forms a hurdle towards the implementation of a new development. However, it can also become an enabling factor once a development has become accepted. The wider context changes only slowly and therefore tend to inhibit change. Nevertheless, developments in the wider context do sometimes also speed up transitions (Pahl-Wostl, 2007; Rotmans et al., 2001). As explained in Chapter 6, the innovative character of the studied cases made that they were often difficult to embed in the Romanian context. According to Dutch experts, projects that are implemented with funds of supranational or international institutions are less flexible and generally have another scope. They are based on specific Terms of Reference and often designed to change institutional or organizational structures. While beneficiaries are interested to learn from foreign experts they can also be reluctant to change. For example, in the regionalisation of Romanian water services, foreign experts experienced that vested interests and misunderstandings caused that actors were reluctant to share responsibilities, to relinquish control of assets and also to take responsibility (Wilson et al., 2006). An important difference between such projects and the studied cases is that these projects are designed to change the institutional context. While such projects face partly the same challenges as the cases, they are less likely to be implemented at a distance of formal policy processes.

What the cases and the other above mentioned projects have in common is that they are not completely voluntary. Generally, they are not directly enforced by external actors. However, they are often rooted in externalities or interdependencies that stimulate an actor to adopt certain policies. This distinguishes them from 'lesson drawing', which refers to the search of policy makers for new knowledge, for example, in response to a problem or to justify policy decisions (Dolowitz \& Marsh, 1996). An example of such lesson drawing is the transfer of knowledge that took place between the Netherlands and the United States following hurricane Katrina. Lesson-drawing is a widespread practice in Europe: the 
exchange of knowledge as well as the development of best practices are strongly promoted by the European Commission (Stead, 2012). Within this context, many Dutch water boards and knowledge institutes are involved in EU-funded projects that stimulate collaboration between European regions (Unie van Waterschappen, 2012). What distinguishes these knowledge transfer projects from the studied cases is that they concern countries with similar resources. According to actors with practical experiences, the transfer of knowledge in such projects is easier. The literature supports this observation by showing that transfers tend to be more effective between countries that are similar in terms of public resources (e.g. economic resources, expertise of civil servants and bureaucratic efficiency) (Rose, 1993). When actors are more similar in terms of resources, many of the problems that were experienced in the case studies are therefore likely to occur less.

\subsection{Concluding remarks}

The theoretical basis for this research is formed by the Contextual Interaction Theory. Through this research, we showed that this theory provides an adequate starting-point for the evaluation of knowledge transfer projects. To explain and predict the outcomes of such projects, we complemented the theory with insights from the literature on evaluation, policy networks, policy transfer, knowledge transfer and management and social learning. By integrating some of these insights into the Contextual Interaction Theory, we contributed to the further development of this theory. We introduced four immediate outcomes (motivating goal, negotiated knowledge, mobilization of resources and positive relational experiences), which help to predict the application or implementation of certain knowledge. We further provided new insights into how learning changes actor characteristics and may contribute to the development of collective outcomes. In addition, we explained how the international context of a process can impact an interactive process via the characteristics of actors involved. The research makes an important contribution to the literature on policy and knowledge transfer, which pays little attention to evaluation, by developing and testing an evaluation framework.

The developed evaluation framework is a practical tool for assessing the effectiveness of knowledge transfer projects. The immediate outcome criteria and the overall framework can serve as a basis for the evaluation of any type of policy or transfer process. The practical and applied focus of the evaluation implies that we developed case-specific process and ultimate outcome criteria. However, researchers can easily develop other criteria that fit case-specific purposes by following similar lines of reasoning. The criteria also serve other than evaluation purposes. Practitioners can use the process criteria in designing a project and the immediate outcome criteria in monitoring the progress. While the developed framework is equally applicable to other types of knowledge transfer projects, the results can diverge. In the discussion, we provided several examples of how some factors may become more or less important in other knowledge transfer projects. We showed that institutional embedding is less relevant for private sector projects and for 
projects that concern lesson-drawing. We further explained that when knowledge is transferred between very different countries, the development of 'mutual understanding in communication' is more challenging, thereby increasing the importance of 'interactional knowledge'. We also showed that Dutch-funded projects are likely to be more successful in countries where external experts have better access to external financial resources and in countries with which the Netherlands has strong bilateral relations. 


\section{Chapter 9}

\section{Conclusions and recommendations}

The aim of the presented research is to provide new insights in the effectiveness of international water projects that involve the transfer of knowledge. Within this context, we define knowledge transfer as the interactive process by which actors of different countries share and acquire knowledge about water management for the purpose of applying that knowledge. This research builds upon the qualitative analysis of three flood risk management projects that were implemented with Dutch support in Romania. In the preceding chapters, we explained the governance setting of these projects (Chapter 2), discussed the experiences of three case projects using different theoretical perspectives (Chapters 3 to 6), compared and discussed the effectiveness of the case studies (Chapter 7) and reflected on our methodology and the generalizability of our findings (Chapter 8). The contents of these various chapters form the basis for this final concluding chapter. The first section of this chapter provides an answer to the research questions that are presented in Chapter 1. Section 9.2 draws recommendations for further research. The last section elaborates some practical implications and recommendations for policy makers and practitioners involved in similar projects as the case studies.

\subsection{Conclusions}

This section provides an answer to our research questions, which includes three subquestions and one central question (see Section 1.2). The first sub-question concerns the effectiveness of knowledge transfer projects. The second sub-question focuses on the interaction process. The third sub-question concerns the role of contextual factors and generalizability. Conclusively, the answers of these sub-questions are synthesized to answer the central question.

\section{Effectiveness of knowledge transfer projects}

Our first question is: What process and outcome criteria help to determine the effectiveness of knowledge transfer projects and how do the cases score on these criteria?

We define the effectiveness of knowledge transfer projects as the degree to which a project contributes to the achievement of intended or desired outcomes. These outcomes are achieved when knowledge is not only shared and acquired, but also applied. To measure effectiveness, we developed an evaluation framework consisting of process, immediate and 
ultimate outcome criteria (Chapter 3). We used this framework to systematically evaluate and compare three Dutch-Romanian flood risk management projects (Chapter 7). We evaluated the process using six criteria that help to measure 'user engagement': stakeholder involvement, institutional embedding, integration of context-specific knowledge, mutual understanding in communication, proactive diffusion strategy and adaptive management. We evaluated the immediate outcomes, which form the basis for the realization of intended or desired outcomes, using four criteria: joint motivating goal, the creation of negotiated knowledge, the mobilization of resources and positive relational experiences. The overall effectiveness of the Dutch-funded cases was evaluated in terms of their contribution to problem-solving and to the generation of follow-up projects. These desired outcomes were not, or not fully, achieved in any of the studied cases. All cases have scores varying from low to medium or high on the process and immediate outcome criteria. We further explain these findings below.

The ultimate outcomes of knowledge transfer projects are best evaluated using 'meta-level' criteria that go beyond the objectives of actors or individual projects. In the case of Dutchfunded projects, we identified two 'meta-level' objectives: the solving of water-related problems and the generation of follow-up projects for the Dutch water sector. None of the cases directly contributed to the solving of water problems. Additional actions need to be taken to actually reduce flood risks or to solve other water-related problems. Follow-up actions were initiated in two cases. However, only in one case the follow-up project that is under preparation is likely to economically benefit the Dutch water sector.

What complicates the evaluation of ultimate outcomes is that they often only become visible on the longer term. Therefore, we looked for immediate outcome criteria that help to predict the realization of desired outcomes. We asserted that knowledge transfer projects are processes of social interaction. The course and outcomes of these interaction processes are basically shaped by the characteristics of actors involved, which are their motivations, cognitions and resources. An interactive process forms the basis for the realization of ultimate outcomes when actor characteristics converge and actors start to trust each other. Such a basis includes the development of a joint motivating goal, the creation of negotiated knowledge (i.e. knowledge that is agreed upon and valid), the mobilization of resources (by pooling them, if necessary) and positive relational experiences (as a basis for trust). The cases have diverse scores on these criteria. In the first case, Romanian participants - mostly local and regional actors - became motivated to implement the project results but were unable to mobilize the resources that are needed for this. Also because of some negative relational experiences, none of the Dutch actors wanted to take the lead in follow-up actions. In the second case, Romanian actors at decision-making positions were in favour of further implementation of a flood information and warning system (FLIWAS) that was tested at a pilot scale. However, potential users were not motivated to start using the system since they were not completely convinced about the applicability and usefulness of FLIWAS. In the third case, actors involved developed a shared view on the existing 
situation but not on how to deal with the issues in the area. The collaboration was positive for Romanian actors who were motivated to continue but lacked the resources to also pay for follow-up actions. The project was disappointing for Dutch actors who became less motivated to collaborate. In all cases, follow-up actions were needed to achieve the desired ultimate outcomes, but in none of the cases actors developed a strong basis for further collaboration. All cases have a moderate overall score on the immediate outcome criteria. We conclude that the effectiveness of an externally supported knowledge transfer project crucially depends on the presence of an actor who is able and willing to coordinate or take the lead in the mobilization of (external, mostly financial) resources. Actors are more motivated to fulfil this role when they had positive collaboration experiences and when a negotiated knowledge base was developed.

The degree of 'user engagement' helps to explain the outcomes of a knowledge transfer project. Users are actors with a crucial role in the implementation of the intervention or in follow-up actions. Projects are more effective when the involvement of users is ensured. We measured user engagement through six criteria: stakeholder involvement, institutional embedding, integration of context-specific knowledge, mutual understanding in communication, proactive diffusion strategy and adaptive management. These criteria are based on the recognition that the studied cases are international pilot projects which are implemented in a dynamic environment and need to integrate the interests and knowledge of various actors with diverse backgrounds. The cases have diverse scores on these criteria. They show that follow-up actions are more likely when actors at decision-making positions are involved in and committed to the project. Therefore, the effectiveness of knowledge transfer projects closely relates to how a project scores on institutional embedding and on diffusion of results, which both require specific knowledge of the institutional setting. Only in one of the studied cases, actors had an adequate understanding of the institutional setting (since they had been involved in similar projects) and were therefore able to raise support among actors with a crucial role in the realization of follow-up actions. None of the cases scores high on adaptive management. In all cases actors failed to successfully adapt the project to new insights or changing circumstances and that Dutch and Romanian actors regularly had difficulties to understand each other. The inclusion of knowledge and perspectives from local stakeholders, i.e. actors who are living and working in the area, was an important component of all cases. The involvement of local stakeholders is of particular importance when moving towards implementation but has less influence on the likelihood of follow-up actions.

\section{Projects as actor-interaction processes}

The second research question reads: How do the interactions between actors with diverse motivations, cognitions and resources shape the process and outcomes of knowledge transfer projects in the cases? 
This research question is answered through an analysis of how actors, their interaction and knowledge shape a transfer process (Chapter 4) and how actor characteristics change as a result of social learning (Chapter 5). We found that in an international setting, direct and intense interaction is often needed for actors to understand each other. Through their interaction, actors can learn from and about each other. Interaction and learning may support and also inhibit the realization of desired outcomes. Learning processes can bring actors closer together forming a basis for further collaboration. However, they may also drift them further apart making the realization of ultimate outcomes less likely.

Knowledge transfer projects are implemented by actors who participate for diverse reasons, interpret reality in diverse ways and have diverse capacities to act and sources of power. Since the cases involved similar actors and had similar objectives, the actors involved had some characteristics in common. Generally speaking, Dutch experts were highly motivated to engage in an international knowledge transfer process. The same applies to most Romanian actors but some of them were also sceptical about the added value of Dutch expertise. Dutch experts generally had the impression that floods and related issues were pressing problems in the project area. This cognition was not shared by all Romanian actors, who sometimes perceived other problems to be more relevant. Romanian and Dutch actors both provided important resources for the project. Financial resources for the project and general knowledge were provided by Dutch actors, whereas specific knowledge and contributions in kind were made by Romanian authorities and other stakeholders. Only in one of the three cases, Dutch experts had experience with water projects in Romania and could therefore also provide specific substantive, procedural and political knowledge. Institutional resources needed for the application of knowledge had to be provided mostly by Romanian actors. Thus, the cases demonstrate that transferring and receiving actors in an international knowledge transfer project have rather diverse motivations and cognitions and complementary resources.

How interactions are organized among actors is one of the factors affecting the course and outcomes of a knowledge transfer project. Generally speaking, more direct and intense interaction means and settings that allow for feedback (e.g. face-to-face communication or workshop settings) are better at communicating the 'tacit' - difficult to express - aspects of knowledge. These tacit aspects play an important role in knowledge transfer projects, which involve actors whose knowledge is rooted in diverse professional, organizational and sociocultural backgrounds. The cases demonstrate that actors with diverse backgrounds often have difficulties to really understand each other - even when actors speak the same language or translation is provided. These differences can be overcome by actors who have knowledge of multiple knowledge domains or contexts (i.e. interactional knowledge). Furthermore, the capacity of actors to transfer knowledge is probably also related to social knowledge that is rooted in relations as well as the ability of actors to develop relations and other personal characteristics. 
In the third case, we used the concept of 'social learning' - learning in interaction with others - to understand how actor characteristics change as a result of the interactive process. We found that interactions provide actors with additional knowledge, insights and skills concerning substantive aspects (e.g. about problems and solutions) and relational aspects (e.g. mutual dependencies, relations and trust). In the same process, the learning by some actors can be constructive (bringing actors closer together) whereas the learning by other actors can be unconstructive (drifting them further apart). For example, in the third case, Dutch actors learnt that local realities were different than they expected, that their approach did not have the intended effects and that their collaboration with Romanian counterparts was not as they had expected. Their learning was unconstructive; it made them decide not to continue the collaboration. Based on their interactions in various settings, two Dutch organizations decided to further collaborate with regional instead of local actors. Romanian actors were disappointed about the process but had positive relational experiences, gained new knowledge and insights and wanted to continue the collaboration. The case demonstrates that learning influences the effectiveness of a project. What matters is not only how much and about what actors learn, but also whose learning has most impact. Collaborative follow-up actions are only to be expected when actors who are in the position to initiate follow-up actions learn constructively.

\section{Contextual factors and generalizability}

The third research question is: How do contextual factors shape the process and outcomes of knowledge transfer projects and what does this imply for the generalizability of the case study results?

The first part of this research question is answered through an assessment of flood risk governance in Romania (Chapter 2) and an analysis of how contextual factors impacted the case studies (Chapter 6). We further reflected on the generalizability of the case study results using the experiences of other researchers and practitioners (Section 8.3). We found that contextual differences are an incentive, but can also form an obstacle when transferring knowledge. The cases confirm that wider and structural contexts do not change as a result of a single project. However, contexts can change rather fast asking for adaptation of a project. The cases further show that collaborative actions are difficult to achieve when they are not supported by the governance context. The cases confirm that not contextual factors, but the motivations, cognitions and resources of actors shape the course and outcomes of interaction processes, including knowledge transfer projects.

One of the starting-points of this research is that contextual factors only influence an interaction process insofar they change the characteristics (i.e. motivations, cognitions and resources) of actors involved. These contextual factors are found in three contextual layers: the wider context (including political, economic, socio-cultural, technological and problem contexts), the structural context (institutional or governance context) and the specific 
context (including previous decisions and circumstances). The cases demonstrate that the international context of knowledge transfer projects influences their course and outcomes in at least two ways. Firstly, transferring actors have another contextual background than receiving actors. These differences are an incentive to collaborate and thus an important source of motivation. However, differences in cognitions and resources are also important sources of disagreement and misunderstandings, which have a negative influence on the course and outcomes of a project. Secondly, knowledge transfer projects aim at applying knowledge (that was developed and applied in the transferring country context) in the receiving country context. The application of knowledge is challenging since the projects are pilots of which the interaction between knowledge and context is unknown. Moreover, the context is not stable but likely to change as a result of external developments. The cases show that in particular the problem context and the political context can change rather fast creating a need for adapting a project. Since the effectiveness of knowledge transfer projects crucially depends on the support provided by actors at decision-making positions, they are particularly influenced by the governance context. The flood risk problems that were addressed in the cases were closely related to problems of fragmented governance. This fragmentation implied, for example, fragmented ownership of flood defence structures, a lack of adequate information about flood risks and conflicting interests and perspectives of actors. While the situation improved with the introduction of a national strategy in recent years, coordination and collaboration continue to be insufficient. Particularly, the involvement of actors of various sectors and levels was problematic in the cases. The underlying reasons for this include that Romanian actors were not used to collaborate and had little insight into the policy process.

This research builds upon the experiences of flood risk management projects that were implemented with Dutch support in Romania. While the evaluation approach and general findings are equally relevant for other knowledge transfer projects, some findings are related to specific features of the studied projects or the country involved. To distinguish between process and immediate and ultimate outcomes is a very useful approach for the evaluation of knowledge transfer projects in general. The immediate outcomes can be applied to any type of interaction process. The process criteria and ultimate outcome criteria are rather specific and are not equally relevant for other knowledge transfers. For example, the generation of follow-up projects is not relevant for all knowledge transfer projects diminishing also the importance of proactive diffusion. Furthermore, when actors transfer knowledge over a longer period of time, for example, within the context of a partnership, they have more time to interact and therefore gradually have less difficulty to understand each other. When the contexts of the transferring and receiving actors are more diverse, the involvement of actors who are used to work in both contexts becomes relatively more important. That the cases were externally supported had a specific influence on the motivations, cognitions and resources of actors. The specific context, and thus actor arena, is rather different for projects that are supported by supranational or international actors or 
that concern countries that are similar in terms of public resources. However, on the basis of this research, we are confident that knowledge transfer projects - in whatever setting they may occur - can be understood by analysing the dynamic interaction between the characteristics of the actors involved.

\section{Synthesis: On the role of actors, interaction and context}

The central question of this thesis is: How do actors' motivations, cognitions and resources, their interactions and contextual factors shape the course and outcomes and influence the effectiveness of international water projects that involve the transfer of knowledge?

We analysed the context, process and outcomes of three projects that were implemented with financial support of the transferring country. From our research, we conclude that externally supported knowledge transfer projects, such as the cases, are less effective than hoped for. We found that collaboration between the actors remains at the level of sharing and acquiring knowledge (which are covered by a project) and does not move forward to the application of knowledge (which requires follow-up actions). To explain this result, we analysed the motivations, cognitions and resources of transferring and receiving actors at various points in time. We found that differences between the actors involved form an incentive and hurdle for their collaboration. Changes in actor characteristics are needed to develop a basis for further collaboration. Such a basis is formed by a joint motivating goal, an agreed upon and valid - negotiated - knowledge base and the mobilization of necessary resources. In addition, positive relational experiences - which form a basis for mutual trust - influence the likelihood of further collaboration.

In collaborative settings, actors learn from and about each other. Regular and intense interactions accelerate learning processes and may bring actors closer together. Learning can be constructive creating a pathway for further collaboration and can also be unconstructive making actors decide to cease from further collaboration. Constructive learning may have all kinds of positive effects but does not necessarily contribute to a project's effectiveness. Required follow-up actions easily get stuck in the absence of an actor who is able and willing to coordinate or take the lead in the mobilization of the necessary resources. Thus, the effectiveness of a project ultimately also depends on the motivations and cognitions of actors who can mobilize the resources needed for follow-up actions.

Contextual factors influence a project through the characteristics of actors involved. Depending on a project's specific setting, the motivations, cognitions and resources of actors interact in different ways. What characterizes many of these projects is that they are pilot projects. They aim to apply knowledge that has not been applied in that specific context before. The degree to which actors manage to adequately embed a project in the receiving context is closely related to its effectiveness. Projects, and externally supported 
projects in particular, easily run the risk of not fitting local realities. Therefore, the effectiveness of knowledge transfer projects crucially depends on the integration of contextspecific knowledge and adequate adaptation to new insights and changing circumstances. This research shows that for knowledge transfer projects to become effective, actors need to move from collaboration to application. Constructive interactions are beneficial but only have the desired impact when actors are also willing and able to apply what they learn from and about each other.

\subsection{Recommendations for further research}

This research is based on real-time case studies implying that the ultimate outcomes of the cases were yet unknown. We therefore recommend evaluating the cases again within a few years to verify their ultimate outcomes. Furthermore, the research focused on a particular type of knowledge transfer projects: Dutch-funded flood risk management projects in Romania. We explored the degree to which our findings apply to knowledge transfer projects in general, but additional research is needed to support our tentative conclusions on generalizability. Therefore, we recommend testing the evaluation framework on a wider selection of Dutch-funded projects. Such a selection ideally includes cases from countries that have weaker versus stronger bilateral relations with the Netherlands, from countries that are relatively more versus less different than the Netherlands, projects in which the private sector has a stronger versus a weaker role and projects that are more isolated versus interconnected with other projects. In addition, we recommend testing the starting-points of the evaluation framework on other types of knowledge transfers, including transfers that are supported by other type of actors (e.g. a benefiting country or a supranational organization). We expect that examining a wider selection of cases does not only support the drawing of more general conclusions, but could also result in new insights on the influence of contextual factors.

On the basis of our experiences with the application of the evaluation framework, we have several ideas for further improving the framework. While comparing the cases, we found that the process criteria are partly overlapping. We further found that some criteria are more important in the design phase whereas others are more important in the implementation phase of a project. Hence, we recommend fine-tuning the process criteria before applying them to a large-N study. On the basis of the cases, we expect that the involvement of actors with specific social and relational abilities has a strong influence on the effectiveness of a project. We therefore recommend paying specific attention to the involvement of actors who are good at translating between actors with diverse backgrounds and at developing and maintaining relations. We further recommend elaborating the predictive part of the evaluation framework further. The current framework helps to predict only two types of interactions, constructive or not. Previous research, in which the interaction setting was simplified to two actors, shows that processes can also lead to other types of interactions, such as learning, active cooperation or obstruction. 
We recommend future research on knowledge transfers to further elaborate the role and influence of learning. One potential direction for research is to examine the need for learning and modification of knowledge before it can be applied in another context. Another direction for research is to examine the impact of learning processes (resulting from an interactive process) on the specific, structural and wider context. For example, we found that an innovative process that seems to be ineffective can still have a large impact on the longer term because it provided large opportunities for learning. The further testing of this idea is very relevant since this could shed light on the relative importance of projects versus other actions and also on the longer term impact of a project. We realize that the answering of such a research question can be very demanding since it requires examining the learning processes of various actors at multiple levels, within the context of multiple actions.

On the basis of our experiences with the use of the Contextual Interaction Theory, we have specific recommendations for the further development and use of this theory. Since the theory offers a compact model for understanding the course and outcomes of transfer processes, we can recommend this theory as a basis for researchers focusing on knowledge transfer. In this research, we used the theory for qualitative purposes but previous research shows that the theory also supports the quantitative analysis of a larger number of cases. When using the theory, we recommend researchers to focus not only on the characteristics of actors involved, but to also examine what other actors are relevant for the implementation of the project of follow-up actions. Furthermore, we recommend investigating not only actor characteristics, but also what binds actors together and how this influences the course and outcomes of a project. For example, we expect that next to positive relational experiences, informal and formal structures and networks also form a basis for trust. Thus, we recommend paying specific attention to the structures and relations that bind actors together.

\subsection{Practical implications and recommendations}

This section presents some practical recommendations for the Dutch water sector as well as for other actors who are involved in similar knowledge transfer processes. First, we reflect on process characteristics that support the realization of ultimate goals. Next, we elaborate a learning oriented approach on knowledge transfer projects as the way forward to become more effective. Together with practitioners, we elaborated these recommendations also in a practical booklet (Vinke-de Kruijf et al., forthcoming in 2013).

\section{Realizing programme goals through engagement}

Our research basically shows that knowledge transfer goals are achieved through the active involvement of the right actors. On the basis of our findings, we present concrete recommendations for implementing actors (contributing to implementation) and supporting 
actors (providing financial support) with a role in knowledge transfer projects. Our recommendations are related to four aspects of a successful knowledge transfer project: actors, interaction, diffusion and learning.

1. Involve actors who have decision-making power or knowledge about the project content, process and network and use their knowledge to improve the project.

Knowledge transfer projects aim at the application of knowledge in a context in which that knowledge has not been applied before. The wider and structural contexts can be dynamic, but are unlikely to change as a result of a single project. This means that actors involved need to work with and within a given context and should know this context. Contextspecific knowledge in the areas of content, process and network can be integrated into a project by involving actors who have relevant experience. Actors of the receiving countries do not necessarily have such knowledge but are usually more likely to have access to such knowledge than external experts. This knowledge can be used to identify 'critical actors' who have a crucial role (e.g. because of their decision-making or obstruction power) in the implementation of a project and its follow-up actions. Supporting actors can promote the integration of context-specific knowledge by making an adequate analysis of the actor network an obligatory aspect of every project. Since the possibilities to adapt the actor constellation of a project are often limited, such an analysis needs to be made in an early stage of a project, preferably in the exploration phase. Such an analysis can shed light on the characteristics of actors at various levels (usually the local, the regional and the national level). Explicit attention needs to be given to the division of responsibilities and resources, the sense of urgency and perceptions concerning the problem. Implementing actors can integrate this in their project design whereas implementing actors can verify whether this has been done.

2. Support the development of a mutual understanding among actors with diverse knowledge backgrounds.

Knowledge transfer projects involve actors with diverse backgrounds who often have not been working with each other before. Through their interactions, these actors can develop a collective basis for further collaboration. However, this is only the case when actors are able to develop a mutual understanding in communication. In international settings, such understanding requires that actors use rather intense and direct communication means. Therefore, implementing actors should organize settings that help actors to really work together, for example, through the organization of workshops or the establishment of small teams. When actors do not speak the same language, translation should be provided. The organization of field visits and the use of visual communication tools are powerful means of communication in international settings. Furthermore, projects preferably involve not only actors who are expert at a certain topic, but also actors with specific relational or interactional qualities. This includes actors who have 'social knowledge' that is embedded in relations and are good at developing and maintaining social relations as well as actors 
with 'interactional knowledge' who can 'translate' between actors with diverse backgrounds and knowledge levels. When implementing and supporting actors take these recommendations into account in designing, implementing or approving a project, their projects will become more successful.

3. 'Spread the word' through the design and the implementation of a proactive diffusion strategy during the project and, if necessary, after project completion.

Knowledge transfer projects often aim at transferring innovative knowledge within a short period of time and limited resources. This research shows that these ambitious goals are unlikely to be achieved through a single project. They require follow-up actions for which actors involved often depend on external resources. Thus, without diminishing the importance of a good process, the diffusion or 'spreading' of the project results is needed to become effective. Actors involved can enhance diffusion by developing and implementing - and adjusting, if necessary - a proactive diffusion strategy. Such a strategy describes what kind of ultimate outcomes the project aims at, which actors can contribute to the realization of such outcomes and how the commitment of these various actors will be obtained. The implementation of diffusion activities preferably starts already in the project preparation phase, continues during the implementation phase (e.g. through progress meetings) and is persisted, if necessary, after project completion. Therefore, real commitment of implementing actors is needed. Both individual actors as well as their organizations should be dedicated to the transfer of knowledge. Within this context, more implementing actors, and thus more organizations, can be a potential advantage and a disadvantage: the involvement of more actors creates more opportunities for pooling resources, but also implies more diverse motivations and cognitions complicating the development of a joint motivating goal. Actors who financially support projects should therefore consider whether implementing actors complement and agree with each other. Furthermore, they can promote diffusion by allocating part of the project budget to dissemination and follow-up activities.

4. Learn during your own project by verifying and, if necessary, adapting the startingpoints to make your project more productive and also learn across projects.

What applies to all projects and to the recommended actions is that they are not static but need to be adapted based on new insights and changing circumstances. Thus, implementing actors should continuously verify each other's interpretations and expectations and, if necessary, adapt the project to new knowledge or insights. Furthermore, they should be aware of any changes in the wider or structural contexts. Practical experiences show that the political context and the governance context often change over time. Also, how a problem is perceived by local or regional actors can change between the preparation and implementation of a project. At the same time, adaptations should be made with care: they should improve the likely project outcomes and not simply reduce the number of concrete outcomes. Thus, even though the opportunities to productively adapt a project may be limited, these opportunities should be used by project implementers and allowed for by 
project supporters. What these actors can further do to enhance the effectiveness of projects is to promote learning across projects. This means that acquired knowledge, insights or capacities concerning relational or substantive aspects is transferred from one project to another. Learning across projects can be promoted through the participation of experienced and less experienced actors as well as through the organization of activities that support the sharing of knowledge.

\section{Towards a longer term perspective on knowledge transfer projects}

Our evaluation focused on the degree to which a project contributes to the solving of waterrelated problems and the generation of follow-up projects. These ultimate outcomes were not invented for this research, they are central in Dutch policies on international water management. Through this research, we learnt that these objectives are rather ambitious and seldom achieved through the implementation of a single project. Water problems are unlikely to disappear just because of the simple transfer of a concept, method or technology; they also require changes in the governance structures. Knowledge transfer projects can make a positive contribution to these change processes but have little impact when they are implemented as isolated projects. What makes projects of added value is, among others, that they are great sources of inspiration for benefiting actors and junior experts, result in concrete knowledge about how (innovative) knowledge interacts with a certain context and force actors to collaborate, thereby reducing the fragmentation in governance. Hence, by promoting relational and substantive learning, every knowledge transfer project is a potential step towards the solving of water problems and the generation of follow-up projects. However, the desired outcomes of knowledge transfer projects are not achieved on a project base, but rather on a project-by-project base.

Recognizing the limitations of single projects, we plea for a longer term perspective on knowledge transfer projects. This means that actors start to think of projects as being part of a longer term programme, which aims at influencing multiple governance levels by various means. In such a programme, projects can function as learning processes with intermediate outcomes, which are building blocks for the realization of desired outcomes. We realize that such a longer term perspective asks considerable efforts of transferring actors. First of all, actors need to become and stay committed for a longer period of time. Next, actors need to actively look for connections with other projects and for opportunities to influence other governance levels. This involves that they actively reflect on what they learn and also look for opportunities to transfer these lessons to their own and other projects. By doing so, we believe that projects can become much more than just another pilot. Lessons learnt and other project outcomes can become a step forward in achieving change. Maybe such an approach involves more steps over a longer period of time, but eventually the sum of these steps will also have impacts at a larger scale. 


\section{References}

Abdulamit, A., \& Tanasescu, M. (2009). Consideraţii privind Registrul Naţional al Barajelor din România - REBAR [Considerations regarding the National Dam Register of Romania - REBAR]. Hidrotehnica, 54(4-5).

Adler, M. J., Anderson, G. D., \& McKinney, D. (2006). Decision Support System For Integrated Water Management in Romania: Recent Developments and Future Plans. Paper presented at the BALWOIS 2006, Ohrid, Macedonia. http://balwois.com/balwois/administration/full_paper/ffp-508.pdf

Alavi, M., \& Leidner, D. (2001). Review: Knowledge management and knowledge management systems: Conceptual foundations and research issues. MIS quarterly, 107-136.

APFM: Associated Programme on Flood Management. (2012). Website APFM. Retrieved 27 April 2012, from www.apfm.info

Apostol, M. (2009). PAID: Law regarding compulsary insurance of dwellings to be enforced on July 1, 2010, Nine O'Clock. Retrieved from http://www.nineoclock.ro/paid-law-regarding-compulsory-insurance-of-dwellingsto-be-enforced-on-july-1-2010/

Baan, P., \& Klijn, F. (2004). Flood risk perception and implications for flood risk management in the Netherlands. International journal of river basin management, 2(2), 113-122.

Babbie, E. (1992). The practice of social research (6th ed.). Belmont, California: Wadsworth, Inc.

Bădescu, G., Sum, P., \& Uslaner, E. M. (2004). Civil Society Development and Democratic Values in Romania and Moldova. East European Politics and Societies, 18(2), 316.

Bandura, A. (1986). Social foundations of thought and action: a social cognitive theory. Englewoods Cliffs, New Jersey, USA Prentice Hall.

Barredo, J. I. (2007). Major flood disasters in Europe: 1950-2005. Natural Hazards, 42(1), 125-148.

BDG. (2008). Market survey Romania and Bulgaria - The Water Sector. EVD report nr. 80MVK16 Retrieved from http://www.evd.nl/zoeken/showbouwsteen.asp?bstnum=227888\&location=\&highl ight $=$ marktverkenning\%20water\%20roemenie.

Beierle, T., \& Konisky, D. (2000). Values, conflict, and trust in participatory environmental planning. Journal of policy analysis and management, 19(4), 587-602.

Bierly, P., Kessler, E., \& Christensen, E. (2000). Organizational learning, knowledge and wisdom. Journal of Organizational Change Management, 13(6), 595-618.

Boh, W. F. (2007). Mechanisms for sharing knowledge in project-based organizations. Information and organization, 17, 27-58. 
Bots, P. W. G., Bijlsma, R. M., Von Korff, Y., Van der Fluit, N., \& Wolters, H. (2011). Supporting the constructive use of existing hydrological models in participatory settings. Ecology and Society, 16(1), 51 [online]. Retrieved from http://www.ecologyandsociety.org/vol16/iss1/art51/

Bresman, H., Birkinshaw, J., \& Nobel, R. (1999). Knowledge transfer in international acquisitions. J. international business studies, 30(3), 439-462.

Bresnen, M., Edelman, L., Newell, S., Scarbrough, H., \& Swan, J. (2003). Social practices and the management of knowledge in project environments. Int. J. Project Management, 21(3), 157-166. doi: 10.1016/s0263-7863(02)00090-x

Bressers, H., \& Lulofs, K. (2010). Analysis of boundary judgements in complex interaction processes. In H. Bressers \& K. Lulofs (Eds.), Governance and complexity in water management: creating cooperation through boundary spanning strategies. Cheltenham; Northhampton: Edward Elgar Publishing.

Bressers, H. T. A. (2004). Implementing sustainable development: How to know what works, where, when and how. In W. M. Lafferty (Ed.), Governance for sustainable development: the challenge of adapting form to function ( $\mathrm{pp}$. 284318). Cheltenham: Edward Elgar Publishing.

Bressers, H. T. A. (2007). Contextual Interaction Theory and the issue of boundary definition: Governance and the motivation, cognitions and resources of actors. (CSTM series Studies and Reports No. 323). Enschede: CSTM. Retrieved from http://www.utwente.nl/cstm/reports/downloads/contextual_interaction_theory.pdf.

Bressers, H. T. A. (2009). From public administration to policy networks: Contextual interaction analysis. In S. Nahrath \& F. Varone (Eds.), Rediscovering Public Law and Public Administration in Comparative Policy Analysis: Tribute to Peter Knoepfel. Lausanne, Switzerland: Presses Polytechniques et Universitaires Romandes.

Bressers, H. T. A., \& Kuks, S. M. M. (2003). What does "governance" mean? From conception to elaboration. In H. Bressers \& W. A. Rosenbaum (Eds.), Achieving sustainable development: The challenge of governance across social scales (pp. 65-88). Westport: Praeger Publishers.

Bressers, H. T. A., \& Kuks, S. M. M. (2013). Water governance regimes: Dimensions and dynamics. International Journal of Water Governance, 1(1-2), 133-156. doi: 10.7564/12-IJWG1

Bressers, H. T. A., \& Kuks, S. M. M. (Eds.). (2004). Integrated Governance and Water Basin Management: Conditions for Regime Change towards Sustainability. Dordrecht-Boston-London: Kluwer Academic Publishers.

Bressers, N. (2011). Co-Creating Innovation: A Systemic Learning Evaluation of Knowledge and Innovation Programmes. $\mathrm{PhD}$ thesis, Erasmus University, Rotterdam, the Netherlands.

Carolan, M. (2006). Social change and the adoption and adaptation of knowledge claims: Whose truth do you trust in regard to sustainable agriculture? Agriculture and human values, 23(3), 325-339. doi: 10.1007/s10460-006-9006-4

CIA. (2012, 31 December). The World Factbook. Romania. Retrieved 4 January 2013, from https://www.cia.gov/library/publications/the-world-factbook/geos/ro.html

Coalition Agreement. (2010). Regeerakkoord VVD - CDA: Vrijheid en verantwoordelijkheid [Coalition agreement VVD-CDA: freedom and responsibility]. Den Haag, the Netherlands. 
Collins, H., \& Evans, R. (2002). The third wave of science studies: studies of expertise and experience. Social Studies of Science, 32(2), 235-296.

Cornelissen, M. A. J. M. (2011). Evaluation of the Ciobarciu Wetland Project: Analysis of the long-term impacts. BSc thesis, University of Twente, Enschede, the Netherlands.

Cutcliffe, J. R., \& McKenna, H. P. (2002). When do we know that we know? Considering the truth of research findings and the craft of qualitative research. International Journal of Nursing Studies, 39(6), 611-618. doi: 10.1016/s0020-7489(01)00063-3

Davenport, T., \& Prusak, L. (1998). Working knowledge: How organizations manage what they know. Boston, Massachusetts: Harvard Business Press.

De Boer, C., \& Bressers, H. T. A. (2011). Complex and Dynamic Implementation Processes: the renaturalization of the Dutch Regge River. Enschede, the Netherlands: University of Twente in collaboration with the Dutch Water Governance Centre. Retrieved from http://purl.utwente.nl/publications/77862

De Boer, C., Vinke-de Kruijf, J., Ozerol, G., \& Bressers, J. T. A. (Eds.). (2013). Water Governance, Policy and Knowledge transfer: International Studies in Contextual Water Management. London: Earthscan from Routledge.

De Boer, C. L. (2012). Contextual Water Management: A Study of Governance and Implementation Processes in Local Stream Restoration Projects. PhD thesis, University of Twente, Enschede, the Netherlands. Retrieved from http://doc.utwente.nl/81724/

de Bruijn, H., \& Ten Heuvelhof, E. F. (2008). Management in Networks: On multi-actor decision making. London - New York: Routledge.

De Bruijn, H., Ten Heuvelhof, E. F., \& In 't Veld, R. J. (2010). Process management: why project management fails in complex decision making processes (2nd edition ed.). Berlin Heidelberg: Springer-Verlag.

De Bruijn, K. M., Green, C., Johnson, C., \& McFadden, L. (2007). Evolving concepts in flood risk management: searching for a common language. In S. Begum, M. J. F. Stive \& J. W. Hall (Eds.), Flood Risk Management in Europe (pp. 61-75). Dordrecht, the Netherlands: Springer.

De Gooijer, K. (2010, 25-29 May 2010). FLIWAS, The Right Information at the Right Place at the Right Time for the Right Persons to Take the Right Decision. Paper presented at the BALWOIS 2010, Ohrid, Republic of Macedonia. Retrieved from http://balwois.com/balwois/administration/full_paper/ffp-1468.pdf

De Jong, M. (2004). The Pitfalls of Family Resemblance. European Planning Studies, 12(7), 1055-1068. doi: 10.1080/0965431042000267902

De Jong, M., \& Edelenbos, J. (2007). An Insider's Look into Policy Transfer in Transnational Expert Networks. European Planning Studies, 15(5), 687-706. doi: 10.1080/09654310701213996

De Jong, M., Lalenis, K., \& Mamadouh, V. (Eds.). (2002a). The theory and practice of institutional transplantation: experiences with the transfer of policy institutions. Dordrecht, the Netherlands: Kluwer Academic Publishers.

De Jong, M., \& Mamadouh, V. (2002). Two contrasting perspectives on institutional transplantation. In M. de Jong, K. Lalenis \& V. Mamadouh (Eds.), The theory and practice of institutional transplantation: experiences with the transfer of policy institutions (pp. 19-32). Dordrecht, the Netherlands: Kluwer Academic Publishers.

De Jong, M., Mamadouh, V., \& Lalenis, K. (2002b). Drawing lessons about lesson drawing: what the case reports tell us about institutional transplantation. In M. de 
Jong, K. Lalenis \& V. Mamadouh (Eds.), The theory and practice of institutional transplantation: experiences with the transfer of policy institutions (pp. 283-299). Dordrecht, the Netherlands: Kluwer Academic Publishers.

De Laat, M. F., \& Simons, P. R. J. (2002). Collective learning: Theoretical perspectives and ways to support networked learning. European Journal for Vocational Training, 27(3), 13-24.

De Moel, H., Van Alphen, J., \& Aerts, J. (2009). Flood maps in Europe-methods, availability and use. Natural Hazards and Earth System Sciences, 9(2), 289-301.

Dery, D. (1984). Problem definition in policy analysis (Sociology of the sciences, ISSN 0167-2320 ; vol. 24 ed.). Lawrance, Kan: University Press of Kansas.

Dinica, V. (2007). An institutional analysis of water management issues in the Teleorman county, Romania. (CSTM Studies and Reports nr. 320). Enschede, The Netherlands: CSTM, University of Twente.

DLG: Service for Land and Water Management. (2009). Room for the River and People in Cat's bend, Romania: Applying interactive spatial design for land- and water management solutions. (Booklet published by DLG).

Dolowitz, D. P., \& Marsh, D. (1996). Who learns what from whom: a review of the policy transfer literature. Political Studies, 44(2), 343-357.

Dolowitz, D. P., \& Marsh, D. (2000). Learning from abroad: The role of policy transfer in contemporary policy making. Governance, 13(1), 5-23. doi: 10.1111/09521895.00121

Dragos, D. C., \& Neamtu, B. (2007). Reforming local public administration in Romania: trends and obstacles. International Review of Administrative Sciences, 73(4), 629648. doi: 10.1177/0020852307083464

Drapa, A. (2009, 24-25 November 2009). Romanian experience on transboundary waters cooperation. Paper presented at the Joint Meeting of the EU Water Initiative's EECCA Working Group and the OECD EAP Task Force's Group of Senior Officials for Water Sector Reform in EECCA, Bucharest. Retrieved from http://www.oecd.org/dataoecd/47/15/44152290.pdf

Dryzek, J. S. (1996). The informal logic of institutional design. In R. E. Goodin (Ed.), The theory of institutional design (pp. 103-125). Cambridge: Cambridge University Press.

EC: European Commission. (2007). Directive 2007/60/EC of the European Parliament and the Council of 23 October 2007 on the assessment and management of flood risks. Official Journal of the European Communities, L288, 27 - 34.

Edelenbos, J., \& Klijn, E. H. (2005). Managing stakeholder involvement in decision making: A comparative analysis of six interactive processes in the Netherlands. Journal of Public Administration Research and Theory, 16(3), 417-446. doi: 10.1093/jopart/mui049

Edelenbos, J., Klok, P. J., \& Tatenhove, J. (2008). The Institutional Embedding of Interactive Policy Making: Insights From a Comparative Research Based on Eight Interactive Projects in the Netherlands. The American Review of Public Administration, 39(2), 125-148. doi: 10.1177/0275074008317157

EEA: European Environment Agency. (2010a). The European Environment - State and outlook 2010: synthesis. (Report No 1/2010). Copenhagen: European Environment Agency. Retrieved from http://www.eea.europa.eu/soer/synthesis.

EEA: European Environment Agency. (2010b). Mapping the impacts of natural hazards and technological accidents in Europe: An overview of the last decade. (EEA 
Technical Report No 13/2010). Copenhagen: European Environment Agency. Retrieved from http://www.eea.europa.eu/publications/mapping-the-impacts-ofnatural.

EEA: European Environmental Agency. (2008). Impacts of Europe's changing climate 2008 indicator-based assessment. (EEA Report No 4/2008). Retrieved from http://www.eea.europa.eu/publications/eea_report_2008_4.

Eshuis, J., \& Stuiver, M. (2005). Learning in context through conflict and alignment: Farmers and scientists in search of sustainable agriculture. Agriculture and human values, 22(2), 137-148.

Eurostat. (2012). GDP per capita in PPS. Retrieved 22 June 2012, from http://epp.eurostat.ec.europa.eu/tgm/table.do?tab=table\&init=1\&plugin=1\&langua ge $=$ en $\&$ pcode $=$ tec 00114

Evans, M. (2004). Understanding Policy Transfer. In M. Evans (Ed.), Policy transfer in global perspective. Aldershot, England: Ashgate Publishing Limited.

Evans, M. (2009a). New directions in the study of policy transfer. Policy Studies, 30(3), 237-241. doi: 10.1080/01442870902863810

Evans, M. (2009b). Policy transfer in critical perspective. Policy Studies, 30(3), 243-268.

Evans, M., \& Davies, J. (1999). Understanding policy transfer: A Multi-level, multidisciplinary perspective. Public Administration, 77(2), 361-385.

Evers, J. (2011). Werk in Uitvoering: De toepassing van Interactive UItvoering in de praktijk. $\mathrm{PhD}$ thesis, University of Twente, Enschede, the Netherlands. Retrieved from http://doc.utwente.n1/77598/

Faludi, A., \& Altes, W. K. (1994). Evaluating communicative planning: a revised design for performance research. European Planning Studies, 2(4), 403-418.

Fay, B. (1996). Contemporary philosophy of social sciences: a multicultural approach. Malden - Oxford - Carlton: Blackwell Publishing.

Fischer, F. (1995). Evaluating Public Policy. Chicago: Nelson-Hall Publishers.

Flood Protection Expert Group. (2009). Flood Action Programme Prut-Siret Sub-Basin. Vienna: International Commission for the Protection of the Danube River (ICPDR). Retrieved from http://www.icpdr.org/main/activities-projects/floodaction-plans.

Flyvbjerg, B. (2001). Making social science matter: why social inquiry fails and how it can succeed again. Cambridge: Cambridge University Press.

Flyvbjerg, B. (2004). Phronetic planning research: theoretical and methodological reflections. Planning Theory \& Practice, 5(3), 283-306.

Friese, S. (2011). Using ATLAS. ti for analyzing the financial crisis data. Forum Qualitative Sozialforschung / Forum: Qualitative Social Research, 12(1), 39.

Gallagher, T. (2005). Theft of a nation: Romania since communism. London: C. Hurst and Co.

Gerlak, A. K., \& Heikkila, T. (2011). Building a Theory of Learning in Collaboratives: Evidence from the Everglades Restoration Program. Journal of Public Administration Research and Theory, 21(4), 619-644. doi: 10.1093/jopart/muq089

Gerring, J. (2006). Case Study Research: Principles and Practices. Cambridge: Cambridge University Press.

GoR: Government of Romania. (2005a). Programului de realizare a Planului national pentru prevenirea, protectia si diminuarea efectelor inundatiilor si a finantarii acestuia [Programme for realization and financing of the national plan for the 
prevention, protection and reduction of flood risks] - Government Decision No. 1309/2005. Monitorul Oficial, 972 (2 November 2005).

GoR: Government of Romania. (2005b). Strategia Nationala de Management al riscului la inundatii: prevenirea, protectia si diminuarea efectelor inundatiilor [National Strategy for Flood Risk Management: prevention, protection and mitigation of flood effects] - Annex 1 to Governmental Ordinance No. 1854/2005. Monitorul Oficial, 72 (26 January 2006).

GoR: Government of Romania. (2006). Programului de redimensionare ecologica si economica in sectorul romanesc al Luncii Dunarii si a finantarii acestuia [Programme for the Ecological and Economic Restoration of the Danube floodplains in the Romanian sector and its financing] - Governmental Ordinance 1208/2006. Monitorul Oficial, 786(18 September 2006).

GoR: Government of Romania. (2007a). Sectoral Operational Programme Environment 2007-2013, Final Version. Bucharest. Retrieved from www.fonduristructurale.ro/Document_Files//mediu/00000029/kq488_POS_Mediu_EN.pdf

GoR: Government of Romania. (2007b). Sectoral Operational Programme Environment 2007-2013: Final Version. Bucharest: Ministry of Environment and Sustainable Development. Retrieved from http://www.fonduristructurale.ro/Document_Files//mediu/00000029/kq488_POS_Mediu_EN.pdf

GoR: Government of Romania. (2009). National Rural Development Programme 20072013, consolidated version December 2009. Ministry of Agriculture, Forests and Rural Development. Retrieved from http://www.madr.ro/pages/dezvoltare_rurala/NRDP-consolidated-version31.03.2009.pdf.

GoR: Government of Romania. (2010). Strategia Nationala de Management al riscului la inundatii pe termen mediu si lung [National Strategy for Flood Risk Management for the medium and long term] - Annex to Governmental Decision No. 846/2010 Monitorul Oficial, 626(6 September 2010).

Groot, S., \& Termes, P. (2009). Room for the river Danube in Cat's bend, Romania: Hydraulic Study. (HKV report PR1295 July 2009). Lelystad, the Netherlands: HKV consultants.

Gummesson, E. (2000). Qualitative methods in management research (2nd ed.). Thousand Oaks: Sage Publications, Inc.

GWP: Global Water Partnership. (2000). Towards Water Security: A framework for action. Stockholm, Sweden and and London, United Kingdom: GWP. Retrieved from http://www.gwptoolbox.org/images/stories/Docs/water\%20security_2000_doc_78 en.pdf.

Hameeteman, S., Suider, A., Van Zaane, M., \& Meijer, N. (Eds.). (2008). Dutch Water Sector 2009-2010. Schiedam: Nijgh Periodieken B.V. in cooperation with Netherlands Water Platform (NWP) and Partners for Water.

Hinds, P. J., Patterson, M., \& Pfeffer, J. (2001). Bothered by abstraction: The effect of expertise on knowledge transfer and subsequent novice performance. Journal of Applied Psychology, 86(6), 1232- 1243.

Hisschemöller, M., \& Hoppe, R. (1995). Coping with intractable controversies: the case for problem structuring in policy design and analysis. Knowledge, Technology \& Policy, 8(4), 40-60. 
Hommes, S. (2008). Conquering Complexity: Dealing with uncertainty and ambiguity in water management. PhD thesis, University of Twente Enschede, The Netherlands Retrieved from http://doc.utwente.nl/60258/

Hommes, S., Hulscher, S. J. M. H., Mulder, J. P. M., Otter, H. S., \& Bressers, H. T. A. (2009a). Role of perceptions and knowledge in the impact assessment for the extension of Mainport Rotterdam. Marine Policy, 33, 146-155. doi: 10.1016/j.marpol.2008.05.006

Hommes, S., Vinke-de Kruijf, J., Otter, H. S., \& Bouma, G. (2009b). Knowledge and Perceptions in Participatory Policy Processes: Lessons from the Delta-region in the Netherlands. Water Resources Management, 23(8), 1641-1663. doi: 10.1007/s11269-008-9345-6

Hooijer, A., Klijn, F., Pedroli, G., \& Van Os, A. (2004). Towards sustainable flood risk management in the Rhine and Meuse river basins: synopsis of the findings of IRMA-SPONGE. River research and applications, 20(3), 343-357.

Huitema, D., Cornelisse, C., \& Ottow, B. (2010). Is the Jury Still Out? Toward Greater Insight in Policy Learning in Participatory Decision Processes - the Case of Dutch Citizens' Juries on Water Management in the Rhine Basin. Ecology and Society, 15(1), 16 [online]. Retrieved from http://www.ecologyandsociety.org/vol15/iss 1/art16/

ICPDR: International Commission for Protection of the Danube River. (1994). Convention on cooperation for the protection and sustainable use of the Danube River (Danube River Protection Convention). Retrieved from http://www.icpdr.org/icpdr-files/6787

ICPDR: International Commission for Protection of the Danube River. (2012). Website ICPDR: About us. Retrieved 31 October 2012, from http://www.icpdr.org/

Index Mundi. (2011, 1 January). Historical Datagraphs per year. Economy: GDP - real growth rate, Romania. Retrieved 4 January 2013, from http://www.indexmundi.com/g/g.aspx?c=ro\&v=66

Ingram, H. (2008). Beyond universal remedies for good water governance: a political and contextual approach. Paper presented at the Paper presented at the Sixth Biennial Rosenberg Water Policy Forum on "Water For Food: Quantity and Quality in a Changing World, Zaragoza, Spain. URL: http://rosenberg.ucanr.org/documents/V Ingram.pdf

Innes, J. E., \& Booher, D. E. (1999). Consensus Building and Complex Adaptive Systems: A Framework for Evaluating Collaborative Planning. Journal of American Planning Association, 65(4), 412-423.

INTERACT. (2012). Danube Region Strategy. Retrieved 5 November 2011, from www.danube-region.eu

Ison, R., Röling, N., \& Watson, D. (2007). Challenges to science and society in the sustainable management and use of water: investigating the role of social learning. Environmental Science and Policy, 10(6), 499-511. doi: 10.1016/j.envsci.2007.02.008

James, O., \& Lodge, M. (2003). The limitations of 'policy transfer' and 'lesson drawing' for public policy research. Political Studies Review, 1, 179-193.

Jeffrey, P., \& Seaton, R. A. F. (2004). A Conceptual Model of 'Receptivity' Applied to the Design and Deployment of Water Policy Mechanisms. Environmental Sciences, 1(3), 277-300. doi: 10.1080/15693430412331291661 
Karstens, S. A. M. (2009). Bridging Boundaries: Making scale choices in multi-actor policy analysis on water management. $\mathrm{PhD}$ thesis, Delft Technical University, Delft.

Knapen, B. (2012, 9 January 2012). Water voor ontwikkeling: brief aan de Tweede Kamer [Water for Development: letter to the Parliament].

Kogut, B., \& Zander, U. (1992). Knowledge of the firm, combinative capabilities, and the replication of technology. Organization science, 3(3), 383-397.

Koontz, T., \& Thomas, C. (2006). What do we know and need to know about the environmental outcomes of collaborative management? Public Administration Review, 66, 111-121.

Koppenjan, J. F. M., \& Klijn, E. (2004). Managing uncertainties in networks: a network approach to problem solving and decision making. London, UK: Routledge.

Kort, A. J. K. (2011). International Knowledge Sharing between Government Organizations in Water Projects: The Case of the Province of Overijssel and Teleorman County. MSc thesis, University of Twente, Enschede.

Koskinen, K. U., Pihlanto, P., \& Vanharanta, H. (2003). Tacit knowledge acquisition and sharing in a project work context. International Journal of Project Management, 21, 281-290.

Kremlis, G., \& Dusik, J. (2005, 9-15 April 2005). The Challenge of the Implementation of the Environmental Acquis Communautaire in the New Member States. Paper presented at the Seventh International Conference on Environmental Compliance and Enforcement, Marrakech, Marocco. Retrieved from www.inece.org/conference/7/vol2/59_Kremlis.pdf

Kroesen, O., de Jong, M., \& Waaub, J. P. (2007). Cross-national transfer of policy models to developing countries: Epilogue. Knowledge, Technology \& Policy, 19(4), $137-$ 142. doi: $10.1007 / \mathrm{bf02914895}$

Krywkow, J. (2009). A Methodological Framework for Participatory Processes in Water Resources Management. $\mathrm{PhD}$ thesis, University of Twente, Enschede, the Netherlands. Retrieved from http://doc.utwente.nl/64058/

Kuks, S., Bressers, H., De Boer, C., Vinke-de Kruijf, J., \& Özerol, G. (2012). Governance assessment tool - Institutional capacity. Enschede, the Netherlands: University of Twente. Retrieved from http://doc.utwente.nl/81075/.

Kuks, S. M. M. (2004). Water Governance and Institutional Change. PhD thesis, University of Twente, Enschede, The Netherlands.

Langkamp, E. J., Wentholt, L., Pengel, B., Vogt, R., Schnitzler, S., \& de Gooijer, K. (2006). NOAH, the right information at the right time at the right place. In J. Van Alphen, E. Van Beek \& M. Taal (Eds.), Floods, from defense to management (pp. 649-652). London: Taylor \& Francis Group.

Leeuwis, C., \& Van den Ban, A. W. (2004). Communication for Rural Innovation: Rethinking Agricultural Extension. Oxford, UK: Blackwell Science Ltd.

Levin, D., \& Cross, R. (2004). The strength of weak ties you can trust: The mediating role of trust in effective knowledge transfer. Management science, 50(11), 1477-1490.

Light, D. (2006). Modern Romania: an historical overview. In D. Phinnemore (Ed.), The EU and Romania: accession and beyond (pp. 3-16). London: Federal Trust for Education and Research.

Lin, B. W., \& Berg, D. (2001). Effects of cultural difference on technology transfer projects: an empirical study of Taiwanese manufacturing companies. International Journal of Project Management, 19(5), 287-293. 
Lucaciu, M. (2005). Territorial flood defense: A Romanian perspective. In J. Marsalek, G. Stancalie \& G. Balint (Eds.), Transboundary Floods: Reducing Risks Through Flood Management. The Netherlands: Springer.

Maarleveld, M., \& Dabgbégnon, C. (1999). Managing natural resources: A social learning perspective. Agriculture and human values, 16(3), 267-280.

Mandarano, L. (2008). Evaluating collaborative environmental planning outputs and outcomes: Restoring and protecting habitat and the New York-New Jersey harbor estuary program. Journal of Planning Education and Research, 27(4), 456-468.

Marsden, G., \& Stead, D. (2011). Policy transfer and learning in the field of transport: A review of concepts and evidence. Transport Policy, 18(3), 492-500. doi: 10.1016/j.tranpol.2010.10.007

MEF: (Romanian) Ministry of Environment. (2008). Studiul: "Redimensionarea ecologica si economica in sectorul romanesc al Luncii Dunarii Inferioare" (REELD) [Study: "Ecological and Economic Restoration of the Romanian part of the lower Danube floodplains"(REELD)]. Retrieved 5 November 2012, from www.mmediu.ro/vechi/lunca dunarii.htm

Min. BuZa: (Dutch) Ministry of Foreign Affairs. (1995). Nota Herijking Buitenlands Beleid [Review of Foreign Policy]. Den Haag: Sdu Uitgeverij. Retrieved from http://www.montesquieuinstitute.eu/9353000/1/j9vvhfxcd6p01cl/vihmlgsy35za\#p1

Min. BuZa: (Dutch) Ministry of Foreign Affairs. (2007, 30 June 2007). Het (WASH: Water, Sanitaire voorzieningen en Hygiëne) akkoord van Schokland [The (WASH: Water, Sanitation and Hygiene) Agreement of Schokland]. Retrieved from http://www.nwp.nl/afbeeldingen/WASH/WASH-akkoord-met-handtekening

Min. V\&W: (Dutch) Ministry of Transport, Public Works and Water Management. (2007). Safeguarding our future: the government's vision of national water policy. Ministry of Transport Public Works and Water Management (Min V\&W).

Min. V\&W: (Dutch) Ministry of Transport, Public Works and Water Management. (2009). National Water Plan 2009 - 2015. Den Haag, the Netherlands: Ministry of Transport Public Works and Water Management. Retrieved from http://english.verkeerenwaterstaat.nl/english/Images/NWP\%20english_tcm249274704.pdf

Min. V\&W: (Dutch) Ministry of Transport, Public Works and Water Management,. (1999). Programma Buitenlandse Waterinzet: Partners voor Water [Programme International Water Management: Partners for Water] Den Haag: Ando BV

Min. V\&W: Min. V\&W: (Dutch) Ministry of Transport, Public Works and Water Management,. (1998). Vierde Nota Waterhuishouding [Fourth National Policy Memorandum on Water Management]. Den Haag, The Netherlands: Sdu Uitgeverij

Min. V\&W: Ministry of Transport Public Works and Water Management. (2006). Spatial Planning Key Decision 'Room for the River': investing in the safety and vitality of the Dutch river basin region. Retrieved from www.ruimtevoorderivier.nl/files/Files/brochures/EMAB\%20PBK\%20Engels.pdf

Ministry of Foreign Affairs of Turkey, \& World Water Council. (2009). Instanbul Ministerial Statement: 5th World Water Forum, Ministerial Statement.

Mossberger, K., \& Wolman, H. (2003). Policy transfer as a form of prospective policy evaluation: Challenges and recommendations. Public Administration Review, 63(4), 428-440. 
Mostert, E. (2006). Integrated Water Resources Management in The Netherlands: How Concepts Function. Journal of contemporary water research and education, 135(1), 19- 27.

Mostert, E., Pahl-Wostl, C., Rees, Y., Searle, B., Tàbara, D., \& Tippett, J. (2007). Social Learning in European River-Basin Management: Barriers and Fostering Mechanisms from 10 River Basins. Ecology and Society, 12(1), 19 [online]. Retrieved from www.ecologyandsociety.org/vol12/iss1/art19/

Muro, M., \& Jeffrey, P. (2008). A critical review of the theory and application of social learning in participatory natural resource management processes. Journal of Environmental Planning and Management, 51(3), 325-344.

Newig, J., Günther, D., \& Pahl-Wostl, C. (2010). Synapses in the network: Learning in governance networks in the context of environmental management. Ecology and Society, 15(4), 24 [online]. Retrieved from http://www.ecologyandsociety.org/vol15/iss4/art24/

NL Agency. (2012). Website NL Agency Retrieved 29 June 2012, from http://www.agentschapnl.nl/

Nonaka, I. (1994). A dynamic theory of organizational knowledge creation. Organization science, 5(1), 14-37.

NWP: Netherlands Water Partnership. (2012). Website Netherlands Water Partnership. Retrieved 29 June 2012, from http://www.nwp.nl/

OECD. (2001). Best Practices in Local Development. Paris, France: OECD. Retrieved from http://www.oecd.org/cfe/leed/bestpracticesinlocaldevelopment.htm.

OECD. (2011). Water Governance in OECD Countries: A Multi-level approach. OECD Studies on Water, Paris, France: OECD publishing. Retrieved from http://dx.doi.org/10.1787/9789264119284-en.

Otter, H. S. (2000). Complex Adaptive Land Use Systems: An Interdisciplinary Approach with Agent-based Models. $\mathrm{PhD}$ thesis, University of Twente, Enschede, the Netherlands.

Owens, K. A. (2008). Understanding how actors influence policy implementation; a comparative study of wetland restorations in New Jersey, Oregon, The Netherlands and Finland. $\mathrm{PhD}$ thesis, University of Twente, Enschede, The Netherlands. Retrieved from http://doc.utwente.nl/60135/

Pahl-Wostl, C. (2002). Towards sustainability in the water sector: The importance of human actors and processes of social learning. Aquatic Sciences, 64(4), 394-411.

Pahl-Wostl, C. (2006). The importance of social learning in restoring the multifunctionality of rivers and floodplains. Ecology and Society, 11(1), 10 [online]. Retrieved from http://www.ecologyandsociety.org/vol11/iss1/art10/

Pahl-Wostl, C. (2007). Transitions towards adaptive management of water facing climate and global change. Water Resources Management, 21(1), 49-62.

Pahl-Wostl, C., Craps, M., Dewulf, A., Mostert, E., Tabara, D., \& Taillieu, T. (2007a). Social learning and water resources management. Ecology and Society, 12(2), 5 [online]. Retrieved from http://www.ecologyandsociety.org/vol12/iss2/art5/

Pahl-Wostl, C., Holtz, G., Kastens, B., \& Knieper, C. (2010). Analyzing complex water governance regimes: the Management and Transition Framework. Environmental Science \& Policy, 13(7), 571-581. doi: 10.1016/j.envsci.2010.08.006

Pahl-Wostl, C., \& Kranz, N. (2010). Water governance in times of change. Environmental Science \&amp; Policy, 13(7), 567-570. doi: 10.1016/j.envsci.2010.09.004 
Pahl-Wostl, C., Sendzimir, J., Jeffrey, P., Aerts, J., Berkamp, G., \& Cross, K. (2007b). Managing change toward adaptive water management through social learning. Ecology and Society, 12(2), 30 [online].

Pahl-Wostl, C., Sendzimir, J., Jeffrey, P., Aerts, J., Berkamp, G., \& Cross, K. (2007c). Managing change toward adaptive water management through social learning. Ecology and Society, 12(2), 30 [online]. Retrieved from http://www.ecologyandsociety.org/vol12/iss2/art30/

Parker, D., \& Fordham, M. (1996). An evaluation of flood forecasting, warning and response systems in the European Union. Water Resources Management, 10(4), 279-302.

Partners voor Water. (2008). Programma Buitenlandse Water Inzet Partners voor Water: voortgangsrapportage 2005-2007 [Programme International Water Input Partners for Water: progress report 2005-2007] Den Haag, the Netherlands: Partners for Water. Retrieved from http://www.partnersvoorwater2.nl/pdf_rapportages/Voortgangsrapportage_PvW_2 2005-2007.pdf.

Partners voor Water. (2012a). Website "Eindrapportage Partners voor Water 2: 2005-2010". Retrieved 29 June 2012, from http://www.partnersvoorwater2.nl

Partners voor Water. (2012b). Website Partners voor Water. Retrieved 29 June 2012, from http://www.partnersvoorwater.nl

Patton, M. Q. (1978). Utilization-focused research. Beverly Hills, London: Sage Publications.

Patton, M. Q. (1999). Enhancing the quality and credibility of qualitative analysis. Health services research, 34(5), 1189-1208.

Patton, M. Q. (2002). Qualitative research and evaluation methods (3rd ed.). Thousand Oaks: Sage.

Peters, B. G., \& Pierre, J. (1998). Governance without Government? Rethinking Public Administration. Journal of Public Administration Research and Theory: J-PART, 8(2), 223-243.

Peters, B. G., \& Pierre, J. (2001). Developments in intergovernmental relations: towards multi-level governance. Policy \& Politics, 29(2), 131-135.

Peters, R. (2012). Factors that contribute to effective Dutch-funded international water projects. A case study: Banger Pilot Polder Project in Semarang, Indonesia. MSc thesis, University of Twente, Enschede, the Netherlands.

Phinnemore, D. (2010). And We'd Like to Thank... Romania's Integration into the European Union, 1989-2007. European Integration, 32(3), 291-308.

Polanyi, M. (1966). The tacit dimension. London: Routledge \& Kegan Paul.

Pretty, J. (2003). Social Capital and the Collective Management of Resources. Science, 302(5652), 1912-1914. doi: 10.1126/science.1090847

Raymond, L. (2006). Cooperation without Trust: Overcoming Collective Action Barriers to Endangered Species Protection. Policy Studies Journal, 34(1), 37-57.

Reddy, N. M., \& Zhao, L. (1990). International technology transfer: A review. Research Policy, 19(4), 285-307. doi: 10.1016/0048-7333(90)90015-x

Reuss, M. (2002). Learning from the Dutch: Technology, Management, and Water Resources Development. Technology and Culture, 43(3), 465-472.

Rist, S., Chiddambaranathan, M., Escobar, C., \& Wiesmann, U. (2006). "It was Hard to Come to Mutual Understanding..."-The Multidimensionality of Social Learning Processes Concerned with Sustainable Natural Resource Use in India, Africa and 
Latin America. Systemic Practice and Action Research, 19(3), 219-237. doi: 10.1007/s11213-006-9014-8

Rittel, H. W. J., \& Webber, M. M. (1973). Dilemmas in a General Theory of Planning. Policy Science, 4, 155-169.

RNE and EVD: Royal Netherlands Embassy and Agency for International Business and Cooperation. (2009). Environment and Water Projects in Romania (3rd Ed, April 2009). Bucharest, Den Haag: Royal Netherlands Embassy and Agency for International Business and Cooperation.

Rogers, P., \& Hall, A. W. (2003). Effective Water Governance. Sweden: Global Water Partnership Technical Committee. Retrieved from www.gwpforum.org/gwp/library/TEC\%207.pdf.

Rose, R. (1993). Lesson-drawing in Public Policy: A Guide to Learning across Space and Time. New Yersey: Chatham House Publishers.

Rossi, P. H., Lipsey, M. W., \& Freeman, H. E. (2004). Evaluation: A systematic approach (7th ed.). Thousands Oaks: Sage Publications, Inc.

Rotmans, J., Kemp, R., \& van Asselt, M. (2001). More Evolution than Revolution: Transition management in public policy. Foresight, 3(1).

Rousseau, D., Sitkin, S., Burt, R., \& Camerer, C. (1998). Not so different after all: A crossdiscipline view of trust. Academy of management review, 23(3), 393-404.

Samuels, P., Klijn, F., \& Dijkman, J. (2006). An analysis of the current practice of policies on river flood risk management in different countries. Irrigation and Drainage, 55, 141-150. doi: 10.1002/ird.257

Schanze, J. (2006). Flood Risk Management - A Basic Framework. In J. Schanze, E. Zeman \& J. Marsalek (Eds.), Flood risk management: hazards, vulnerability and mitigation measures (pp. 1-20). Dordrecht, the Netherlands: Springer.

Schon, D. (1983). The reflective practitioner: how professionals think in action. USA: Basic Books.

Schusler, T. M., Decker, D. J., \& Pfeffer, M. J. (2003). Social learning for collaborative natural resource management. Society \& Natural Resources, 16(4), 309-326.

Scriven, M. (1991). Evaluation thesaurus (4th ed.). Newbury Park, London, New Delhi: Sage Publications.

Seaton, R. A. F., \& Cordey-Hayes, M. (1993). The development and application of interactive models of industrial technology transfer. Technovation, 13(1), 45-53. doi: 10.1016/0166-4972(93)90013-1

Sehring, J. (2009). Path dependencies and Institutional Bricolage in Post-Soviet Water Governance. Water Alternatives, 2(1), 61-81.

Serban, P., \& Galie, A. (2006). Managementul apelor. Principii si reglementari europene [Water management: European principles and regulations]. Bucharest: Editura Tipored.

Siggel, E. (1986). Technology transfers to developing countries through consulting engineers: A model and empirical observations from Canada. The Developing Economies, 24(3), 229-250.

Stead, D. (2012). Beste Practices and Policy Transfer in Spatial Planning. Planning Practice and Research, 27(1), 103-116. doi: 10.1080/02697459.2011.644084

Stenmark, D. (2002, 7-10 January 2002). Information vs. Knowledge: The Role of intranets in Knowledge Management. Paper presented at the Proceedings of the 35th Hawaii International Conference on System Sciences, Hawaii. Retrieved from http://ieeexplore.ieee.org/stamp/stamp.jsp?tp=\&arnumber=994043 
Steyaert, P., \& Jiggins, J. (2007). Governance of complex environmental situations through social learning: a synthesis of SLIM's lessons for research, policy and practice. Environmental Science and Policy, 10(6), 575-586.

Stone, D. (1999). Learning lessons and transferring policy across time, space and disciplines. Politics, 19(1), 51-59.

Stringer, L., Scrieciu, S., \& Reed, M. (2009). Biodiversity, land degradation, and climate change: participatory planning in Romania. Applied Geography, 29(1), 77-90.

Svensson, R. (2007). Knowledge transfer to emerging markets via consulting projects. The Journal of Technology Transfer, 32(5), 545-559. doi: 10.1007/s10961-007-9034-2

Swainson, R., \& de Loe, R. C. (2011). The importance of context in relation to policy transfer: a case study of environmental water allocation in Australia. Environmental Policy and Governance, 21, 58-69. doi: 10.1002/eet.564

Tàbara, J. D., \& Pahl-Wostl, C. (2007). Sustainability learning in natural resource use and management. Ecology and Society, 12(2), 3 [online]. Retrieved from http://www.ecologyandsociety.org/vol12/iss2/art3/

Teodosiu, C. (2007). Challenges for Integrated Water Resources Management in Romania. Environmental Engineering and Management Journal, 6(5), 363-374.

Teodosiu, C., Barjoveanu, G., \& Teleman, D. (2003). Sustainable Water Resources Management 1. River Basin Management and the EC Water Framework Directive. Environmental Engineering and Management Journal, 2(4), 377-394.

Tews, K. (2009). From law taking to policy making. The environmental dimension of the EU accession process-challenges, risks and chances for the SEE countries. Environmental Policy and Governance, 19(2), 130-139.

Tihanyi, L., \& Roath, A. S. (2002). Technology transfer and institutional development in Central and Eastern Europe. Journal of World Business, 37(3), 188-198.

Topteam Water. (2011). Advies Topsector Water: Water verdient het [Advise Top Sector Water: Water deserves it]. Den Haag, the Netherlands: Topteam Water. Retrieved from http://www.top-sectoren.nl/water/document/adviesrapport-water

Toussaint, B. (2009). Dutch designs in Japan: the impact of Dutch water management experts on Japanese water management. Tokyo: Embassy of the Kingdom of the Netherlands in Tokyo.

Trott, P., Cordey-Hayes, M., \& Seaton, R. A. F. (1995). Inward technology transfer as an interactive process. Technovation, 15(1), 25-43. doi: 10.1016/01664972(95)96609-W

UN-Water. (2006). Water: A shared responsibility. The United Nations World Water Development Report 2

UNECE. (2000). Guidelines on Sustainable Flood Prevention.

UNECE. (2009). River basin commissions and other institutions for transboundary water cooperation: Capacity for water cooperation in Eastern Europe, Caucasus and Central Asia.

Unie van Waterschappen. (2005). Cooperation between Apele Romane and Dutch Water Boards. Den Haag, the Netherlands: Unie van Waterschappen.

Unie van Waterschappen. (2011). Nederlandse waterschappen en het buitenland 2010: Inventarisatie van internationale activiteiten van waterschappen (Dutch water boards and foreign countries 2010: inventory of the international activities of the water boards). Den Haag, the Netherlands: Union of Water Boards. Retrieved from http://www.uvw.nl/download.php?f=e8b62ece36a617955e570e647975c24c. 
Unie van Waterschappen. (2012). Nederlandse waterschappen en het buitenland 2011: Inventarisatie van internationale activiteiten van waterschappen (Dutch water boards and foreign countries 2011: inventory of the international activities of the water boards). Den Haag, the Netherlands: Union of Water Boards. Retrieved from http://www.uvw.nl/download.php?f=237a9cb2c6ac5443063cf33bc24cd633.

UNISDR. (2011). Global Assessment Report on Disaster Risk Reduction. from http://www.preventionweb.net/gar

United Nations (Cartographer). (2008). Map No. 3661 Rev. 5. Retrieved from http://mapsof.net/map/un-romania

Vadineanu, A., \& Preda, E. (2008). Watersheds Management in Romania: Challenges and Opportunities. In I. E. Gönenç, A. Vadineanu, J. P. Wolflin \& R. S. Russo (Eds.), Sustainable Use and Development of Watersheds. Dodrecht, the Netherlands: Springer.

Van Alphen, J., \& Lodder, Q. (2006). Integrated Flood Management: experiences of 13 countries with their implementation and day-to-day management. Irrigation and Drainage, 55(S1), S159- S171 doi: 10.1002/ird.251

Van Assche, K., Duineveld, M., Beunen, R., \& Teampau, P. (2011). Delineating Locals: Transformations of Knowledge/Power and the Governance of the Danube Delta. Journal of Environmental Policy and Planning, 13(1), 1-21. doi: 10.1080/1523908X.2011.559087

van Ast, J. A. (1999). Trends towards interactive water management; developments in international river basin management. Physics and Chemistry of the Earth, Part B, 24(6), 597-602.

Van de Riet, A. W. T. (2003). Policy analysis in multi-actor policy settings : navigating between negotiated nonsense and superfluous knowledge $\mathrm{PhD}$ thesis, Technische Universiteit Delft, Delft. Retrieved from http://repository.tudelft.nl/view/ir/uuid\%3Ac406a7ca-e15a-4b62-b5c7bc64a05fcac6/

Van de Ven, A. H. (2007). Engaged Scholarship: A Guide for Organizational and Social Research. Oxford: Oxford University Press.

Van der Brugge, R., \& Rotmans, J. (2007). Towards transition management of European water resources. Water Resources Management, 21(1), 249-267.

Van der Brugge, R., Rotmans, J., \& Loorbach, D. (2005). The transition in Dutch water management. Regional Environmental Change, 5(4), 164-176.

van der Molen, J. (2011). Crossing borders : een kader voor het tot ontwikkeling brengen van grensoverschrijdende samenwerking in watermanagement (Crossing borders: a framework for the development of cross-border regional cooperation in water management). PhD thesis, University of Twente, Enschede, the Netherlands.

Van der Tol, J. (2011, 4 October 2011). Barriers and dams: exporting Holland's sea defences, Radio Netherlands Worldwide. Retrieved from http:/www.rnw.nl/english/article/barriers-and-dams-exporting-hollands-seadefences

Van Dijk, J. M. (2008). Water and Environment in Decision-making: Water Assessment, Environmental Impact Assessment, and Strategic Environ-mental Assessment in Dutch Planning. A Comparison. PhD thesis, Wageningen University, Wageningen, The Netherlands. Retrieved from http://edepot.wur.nl/121981

Van Maanen, J., Sorensen, J. B., \& Mitchell, T. R. (2007). The interplay between theory and method. Academy of management review, 32(4), 1145-1154. 
Van Peppen, D. (2008). Concept strategie NWP Roemenie Platform [Draft strategy NWP Romania Platform]. Den Haag, the Netherlands: Netherlands Water Platform (NWP).

Vewin. (2009). Eenheid in verscheidenheid [unity in diversity]: towards a more effective approach for Millennium Development Goal 7c. Rijswijk, the Netherlands: Association of Dutch Water Companies.

Vinke-de Kruijf, J. (2009a). Applying Dutch Water Expertise Abroad: How to Contribute Effectively in the Romanian Context. Theoretical Framework. (CE\&M research report 2009R-002/WEM-002). Enschede, the Netherlands: University of Twente. Retrieved from http://purl.utwente.nl/publications/77885.

Vinke-de Kruijf, J. (2009b). Dutch expertise in Romanian water projects: retrospective case study 'Teleorman Flood Risk Management Pilot Project'. (CE\&M research report 2009R-004/WEM-004). Enschede, the Netherlands: University of Twente. Retrieved from http://purl.utwente.nl/publications/77884.

Vinke-de Kruijf, J. (2011a). The role of Dutch expertise in Romanian water projects: Case study 'Pilot implementation FLIWAS in Banat region, Romania'. (CE\&M research report 2011R-02/WEM-002). Enschede, the Netherlands: University of Twente. Retrieved from http://purl.utwente.nl/publications/77882.

Vinke-de Kruijf, J. (2011b). The role of Dutch expertise in Romanian water projects: Case study 'Room for the River in Cat's bend, Romania'. (CE\&M research report 2011R-001/WEM-001). Enschede, the Netherlands: University of Twente. Retrieved from http://doc.utwente.nl/77883.

Vinke-de Kruijf, J. (2011c). The role of Dutch expertise in Romanian water projects: Case study 'Room for the River in Cat's bend, Romania'. (CE\&M research report 2011R-001/WEM-001). Enschede, the Netherlands: University of Twente. Retrieved from http://doc.utwente.nl/77883.

Vinke-de Kruijf, J. (2012). The role of Dutch expertise in Romanian water projects: Case study 'Integrated Water Management in the Tecucel River Basin'. (CE\&M research report 2012R-001/WEM-001). Enschede, the Netherlands: University of Twente. Retrieved from http://doc.utwente.nl/80901/.

Vinke-de Kruijf, J., Augustijn, D. C. M., \& Bressers, H. (2012). Integrated and participatory planning to create more Space for the River Danube in Romania. In J. F. Warner, A. Van Buuren \& J. Edelenbos (Eds.), Making Space for the River: Governance experiences with multifunctional river flood management in the US and Europe (pp. 163-174). London: IWA Publishing.

Vinke-de Kruijf, J., Bressers, H. T. A., \& Augustijn, D. C. M. (forthcoming). Integrated management of the lower Danube River: experiences with the application of Dutch policy concepts and interactive planning methods. In C. Iordachi \& K. Van Assche (Eds.), The biopolitics of the Danube Delta: nature, history and policies. Budapest New York: CEU Press.

Vinke-de Kruijf, J., Dinica, V., \& Augustijn, D. C. M. (2009). Reorganization of water and wastewater management in Romania: from local to regional water governance. Journal of Environmental Engineering and Management, 8(5), 1061-1071.

Vinke-de Kruijf, J., Hommes, S., \& Bouma, G. (2010). Stakeholder participation in the distribution of freshwater in the Netherlands. Irrigation and Drainage Systems, 24, 249-263. doi: 10.1007/s10795-010-9097-3

Vinke-de Kruijf, J., Hulscher, S. J. M. H., \& Bressers, J. T. A. (2011, 27-29 September 2011). Knowledge transfer in international cooperation projects: experiences from 
a Dutch-Romanian project. Paper presented at the 5th International Conference on Flood Risk Management (ICFM5), Tokyo, Japan

Vinke-de Kruijf, J., Kuks, S. M. M., \& Augustijn, D. C. M. (2013). Connective capacity in a dynamic context: changing water governance structures in Romania. In J. Edelenbos, N. Bressers \& P. Scholten (Eds.), Water governance as connective capacity. Surry-London, United Kingdom: Ashgate Publishers.

Vinke-de Kruijf, J., Van Peppen, P., Ottow, B., Sannen, A., \& Udo, J. (forthcoming in 2013). How to facilitate the effective transfer of knowledge in international water projects: Lessons from Dutch research and practice. The Hague, the Netherlands: Partners voor Water.

Vreugdenhil, H. (2010). Pilot projects in water management: Practicing change and changing practice. PhD thesis, Delft University of Technology, Delft, the Netherlands. Retrieved

from http://repository.tudelft.nl/view/ir/uuid\%3A91bda74b-cf5d-4caf-8159$1 \mathrm{e} 57650291 \mathrm{cc} /$

Vreugdenhil, H., Slinger, J., Thissen, W., \& Rault, P. (2010). Pilot projects in water management. Ecology and Society, 15(3), 13 [online]. Retrieved from http://www.ecologyandsociety.org/vol15/iss3/art13/ES-2009-3357.pdf

Walter, A. I., Helgenberger, S., Wiek, A., \& Scholz, R. W. (2007). Measuring societal effects of transdisciplinary research projects: Design and application of an evaluation method. [Article]. Evaluation and Program Planning, 30(4), 325-338. doi: 10.1016/j.evalprogplaii.2007.08.002

Wang, S., \& Noe, R. A. (2010). Knowledge sharing: A review and directions for future research. Human Resource Management Review, 20, 115-131.

Website HKV. (2011, 22 November 2011). HKV verwerft een grote EU Flood Directive opdracht in Roemenië. 11 June 2012

from http://www.hkv.nl/news.asp?id=559681\&pid=3431\&mid=0

Wesselink, A. (2007a, 12-15 November 2007). Integration of interests and expertise in the adaptation to climate change in The Netherlands. Paper presented at the International conference on adaptive and integrative water management (CAIWA), Basel, Switzerland. Retrieved from www.newater.uos.de/caiwa/papers.htm

Wesselink, A., De Vriend, H., Barneveld, H., Krol, M., \& Bijker, W. (2009). Hydrology and hydraulics expertise in participatory processes for climate change adaptation in the Dutch Meuse. Water Science \& Technology, 60(3), 583-595. doi: 10.2166/wst.2009.412

Wesselink, A. J. (2007b). Integraal waterbeheer: de verweving van expertise en belangen [Integrated Water Management: the interweaving of expertise and interests]. $\mathrm{PhD}$ thesis, University of Twente, Enschede. Retrieved from http://doc.utwente.nl/58033/

Wilson, R., Schoon, C., Uifalean, A., \& Peacock, E. B. (2006). Instituting change: regionalising the water business in Romania. Civil Engineering, 159(5), 50-57. doi: $10.1680 /$ cien.2006.159.5.50

WMO: World Meteorological Organization. (2009). Integrated Flood Management: Concept Paper. Geneva, Switzerland: World Meteorological Organization. Retrieved from www.apfm.info/pdf/concept_paper_e.pdf.

Wolman, H., \& Page, E. (2002). Policy Transfer among Local Governments: An Information-Theory Approach. Governance: An International Journal of Policy and Administration, 15(4), 577-501. 
Wong, C. M., Williams, C. E., Pittock, J., Collier, U., \& Schelle, P. (2007). World's top 10 rivers at risk. Gland, Switzerland: WWF International. Retrieved from http://worldwildlife.org/publications/world-s-top-10-rivers-at-risk.

WWAP: World Water Assessment Programme. (2012). The United Nations World Water Development Report 4: Managing Water under Uncertainty and Risk. Paris: UNESCO.

WWF. (2010, 17 February 2010). A decade on lower Danube exceeds green corridor targets (News). Retrieved 14 January 2011, from http://wwf.panda.org/about_our_earth/about_freshwater/freshwater_news/?189121 /A-decade-on-lower-Danube-exceeds-green-corridor-targets

WWF Germany. (2009). Atlas for the Lower Danube Green Corridor.

Yanow, D., \& Schwartz-Shea, P. (Eds.). (2006). Interpretation and method: empirical research methods and the interpretive turn. New York: ME Sharpe.

Yin, R. K. (2009). Case study research: design and methods (4th ed.). Thousand Oaks, California: Sage Publications.

Zaharia, L., C., S., Craciun, E., \& Toroimac, G. (2008). Flood vulnerability of Tecuci city : the role of natural and socio-economic factors. Revista Riscuri si catastrofe, $\operatorname{VII}(5), 130-140$.

Zaman, G., \& Cristea, A. (2011). EU Structural Funds Absorption in Romania: Obstacles and Issues. Romanian Journal of Economics, 32(1 (41)), 60-77. 


\section{Annex I - List of interviewed and consulted persons}

\section{Interviews Romanian water sector}

Violeta Cozianu (three times), Royal Dutch Embassy (Bucharest)

Irina Feleaga, Teleorman County Council (Alexandria)

Dana Banu, Water Management Centre (Turnu Magarele)

Cristian Barbu, Arges-Vedea Water Branch (Pitesti)

Mr. Velea, Teleorman Water Management System (Alexandria)

Camelia Ionescu (twice), WorldWide Fund for Nature (Bucharest)

Claudia Jianu, Terra Millennium III (Bucharest)

Florentina Nanu, BDG Consultants (Bucharest)

Gabriel Muntean (twice), Banat Water Branch (Timisoara)

Doru Purdea, Banat Water Branch (Timisoara)

Niculae Teodorescu, Banat Water Branch (Timisoara)

Catalin Aldescu, Alecsandra Jaica \& Mihaela Soroceac, Banat Water Branch (Timisoara)

Eliza Teodorescu \& Adrian Badila, Alma-Ro (Bucharest)

Petruta Moise, Eco-counseling Galati (Galati)

Daniela Radulescu, National Institute for Hydrology and Water Management (Bucharest)

Bogdan Ion, National Institute for Hydrology and Water Management (Bucharest)

Mary-Jeanne Adler, Ministry of Environment (Bucharest)

Prof. Drobot, Technical University of Civil Engineering Bucharest (Bucharest)

Dan Badarau, Prut Water Branch (Iasi)

Ionut Caraene, Prut Water Branch (Iasi)

Iulian Nichersu \& Cristian Trifanov, Danube Delta National Institute (Tulcea)

Mihaela Oproiu, Haskoning Romania (Bucharest)

Ionela Nicoara, National Institute for Hydrology and Water Management (Bucharest) 
Anca Savin, Prut Water Branch (Iasi)

Calin Arnautu, Arcadis Iasi (Iasi)

Mr. Aloman, Bucuimeni Municipality (Tecuci)

Anca Pintilie, Project coordinator (Tecuci)

Mr. Brailescu, Water company of Tecuci (Tecuci)

Mr. Cuilei, Water company of Tecuci (Tecuci)

Mr. Miron, Municipality of Tecuci (Tecuci)

Mrs. Condurache, Water company of Galati (Galati)

Mrs. Stamate, Water company of Galati (Galati)

\section{Interviews Dutch water sector}

Arnejan van Loenen, Hydrologic (phone)

Alex Hooijer, Royal Haskoning (Nijmegen)

Herman Klomp \& Leo Hendriks, Province of Overijssel (Zwolle)

Ronald Broekhuizen, Dienst Landelijk Gebied (Utrecht)

Gytha van de Veer, Dienst Landelijk Gebied (Arnhem)

Mark Obbink, Dienst Landelijk Gebied (Arnhem)

Pieter Boone, Dienst Landelijk Gebied (Utrecht)

Susanne Groot, HKV $\underline{\text { CONSULTANTS }}$ (Amsterdam)

Cathelijne van Haselen, Royal Haskoning (phone)

Job Udo, HKV $\mathrm{V}_{\text {CONSULTANTS }}$ (phone)

Robin Nicolai, $\mathrm{HKV}_{\text {CONSULTANTS }}$ (phone)

Kees de Gooijer, HKV $\mathrm{V}_{\text {CONSUlTANTS }}$ (phone)

Harry Venema, Arcadis Consultant (Groningen)

Willem Tjebbe Oostenbrink, Dienst Landelijk Gebied (Groningen)

Janet Hidding, Regional Water Authority Hunze en Aa's (Veendam)

Henk van Norel, Regional Water Authority Hunze en Aa's (Veendam)

Brendo Meulman, Landustrie (Sneek)

Roel van Buuren, Water company Groningen (Groningen)

Dennis van Peppen, Agentschap NL/Partners for Water (phone)

Ad Sannen, Royal Haskoning (phone)

Ad Doppenberg, Vitens-Evides International (phone) 
Lennart Silvis, Netherlands Water Partnership (phone)

Paul van Koppen, Kopconsult (phone)

\section{Consultation Dutch water sector (user committee)}

For the implementation of this research, we established a user committee consisting of representatives of the Dutch water sector. Every half year, this committee met to critically reflect and advise on the research approach and results.

Leo Hendriks, Province of Overijssel (until May 2011)

Willem Tjebbe Oostenbrink, Dienst Landelijk Gebied

Dennis van Peppen, Agentschap NL/Partners for Water

Job Udo, HKV $\underline{\text { CONSULTANTS }}$

Ad Sannen, Royal Haskoning

Erik Ruijgh, Deltares

Henk Loijenga, Het Waterschapshuis (until 2011)

Marcel de Ruijter, Unie van Waterschappen (since 2011) 


\section{About the author}

\section{Curriculum Vitae}

Joanne was born as Joanne de Kruijf in Amersfoort in 1983. In 1989, she moved with her family from Maarn to Rhenen. Eight years later, she moved southwards, to Grubbenvorst, where she lived until she finished her pre-university education (VWO) in 2001. Then, she moved to Enschede where she started a Bachelor in Civil Engineering and became an active member, and later also chairman, of student association C.S.V. Alpha. In this period, she developed a particular interest for international water management and knowledge transfer. She did a minor on knowledge transfer in organizations and went for her bachelor thesis research to Cameroon, where she investigated the sustainability of rural water supply systems. In 2005, she started a master with courses in Water Engineering and Management alongside some courses on process management and the like. Her master thesis research was connected to $\mathrm{PhD}$ research of Saskia Hommes and focused on problem structuring in water management projects. She executed this research at the Netherlands Organisation for Applied Scientific Research (TNO) in Delft. In 2007, she obtained her MSc degree in Civil Engineering and Management cum laude.

After finalizing her master thesis, Joanne worked for short periods of time at Deltares and the University of Twente. In May 2008, she went together with her husband to Romania, where she executed most of her $\mathrm{PhD}$ research. In Romania, she participated in various projects and contributed to the development of the collaboration between the University of Twente and the "Gheorghe Asachi" Technical University if Iaşi. At the University of Twente, Joanne was involved in the supervision of two master students and one bachelor student and in the teaching of a bachelor course. In collaboration with several colleagues at CSTM, she organized a discussion group on the Contextual Interaction Theory and edited a book on water governance, policy and knowledge transfer. She participated in two Summer Schools and various trainings and presented her work at various international conferences and events. She implemented her research in close collaboration with practitioners. On a regular basis, she organized user committee meetings. Besides this, she organized a minisymposium for practitioners and helped to develop a booklet that translates her research findings into day-to-day practice.

Joanne currently works as project leader at regional water authority 'Regge en Dinkel', where she is responsible for the overall management of the Interreg IVB project 'Benefit of 
governance in drought adaptation (DROP)'. She was granted a Marie Curie Intra European Fellowship for her proposal 'KNOW2ADAPT'. In her future research, Joanne plans to develop new insights in the transfer of water management knowledge in relation to climate change adaptation. Building on experiences of European projects, she will investigate the role of contextual factors in more detail. She will particularly explore the role of learning and adaptation in the successful transfer of knowledge. She developed this proposal in close collaboration with the group of Professor Claudia Pahl-Wostl at the University of Osnabrück. Starting from 2014, she plans to work there for a period of two years.

\section{List of publications}

\section{Journal articles}

Vinke-de Kruijf, J., Kuks, S. M. M., \& Augustijn, D. C. M. (submitted). Flood problems from a governance perspective: an assessment of flood risk governance in Romania.

Vinke-de Kruijf, J., Bressers, H. T. A., \& Augustijn, D. C. M. (accepted). How Social Learning Influences Further Collaboration: Experiences from an International Collaborative Water Project. Ecology and Society.

Vinke-de Kruijf, J., Augustijn, D. C. M., \& Bressers, J. T. A. (2012). Evaluation of policy transfer interventions: lessons from a Dutch-Romanian planning project. Journal of Environmental Policy and Planning, 14(2), 139-160.

Vinke-de Kruijf, J., Hommes, S., \& Bouma, G. (2010). Stakeholder participation in the distribution of freshwater in the Netherlands. Irrigation and Drainage Systems, 24, 249-263.

Hommes, S., Vinke-de Kruijf, J., Otter, H. S., \& Bouma, G. (2009). Knowledge and perceptions in participatory policy processes: Lessons from the Delta-region in the Netherlands. Water Resources Management, 23(8), 1641-1663.

Vinke-de Kruijf, J., Dinica, V., \& Augustijn, D. C. M. (2009). Reorganization of water and wastewater management in Romania: from local to regional water governance. Journal of Environmental Engineering and Management, 8(5), 1061-1071.

\section{Books and book chapters}

Vinke-de Kruijf, J., Augustijn, D. C. M., \& Bressers, H. (2012). Integrated and participatory planning to create more Space for the River Danube in Romania. In J. F. Warner, A. Van Buuren \& J. Edelenbos (Eds.), Making Space for the River: Governance experiences with multifunctional river flood management in the US and Europe (pp. 163-174). London: IWA Publishing.

Vinke-de Kruijf, J., Hulscher, S. J. M. H., \& Bressers, J. T. A. (2013). Knowledge transfer in international cooperation projects: experiences from a Dutch-Romanian project. In In A, Chavoshian, \& K. Takeuchi (Eds.), Floods from Risk to opportunity (pp. 423434). IAHS Publication 357. Oxfordshire: IAHS Press. 
De Boer, C., Vinke-de Kruijf, J., Ozerol, G., \& Bressers, J. T. A. (eds.). (forthcoming in 2013). Water Governance, Policy and Knowledge transfer: International Studies in Contextual Water Management. London: Earthscan from Routledge.

- Introduction. By: Gül Özerol, Joanne Vinke-de Kruijf and Cheryl de Boer

- Water Management Solutions: On Panaceas and Policy Transfer. By: Joanne Vinke-de Kruijf and Gül Özerol

- How Contextual Factors Influence the Effectiveness of International Projects: The Case of Dutch-funded Flood Risk Management Projects in Romania. By: Joanne Vinke-de Kruijf, Carmen Teodosiu, Hans Bressers and Denie Augustijn

- Conclusions. By: Joanne Vinke-de Kruijf, Gül Özerol, Cheryl de Boer and Hans Bressers

Vinke-de Kruijf, J., Kuks, S. M. M., \& Augustijn, D. C. M. (2013). Connective capacity in a dynamic context: changing water governance structures in Romania. Accepted for publication in: Edelenbos, J., Bressers, N., Scholten, P., eds. Water Governance as Connective Capacity. Surray, United Kingdom: Ashgate Publishing.

Vinke-de Kruijf, J., Bressers, H. T. A., \& Augustijn, D. C. M. (forthcoming). Integrated management of the lower Danube River: experiences with the application of Dutch policy concepts and interactive planning methods, Accepted for publication in: Iordachi, C., \& Van Assche, K., eds. The biopolitics of the Danube Delta: Nature, history and policies. Budapest New York: CEU Press.

\section{Reports}

Vinke-de Kruijf, J. (2012). The role of Dutch expertise in Romanian water projects: Case study 'Integrated Water Management in the Tecucel River Basin'. CE\&M research report 2012R-001/WEM-001, University of Twente, Enschede, the Netherlands. Available: http://doc.utwente.nl/80901/

Vinke-de Kruijf, J. (2011). The role of Dutch expertise in Romanian water projects: Case study 'Pilot implementation FLIWAS in Banat region, Romania'. CE\&M research report 2011R-02/WEM-002, ISSN 1568-4652, University of Twente, Enschede, the Netherlands. Available: http://doc.utwente.nl/77882/

Vinke-de Kruijf, J. (2011). The role of Dutch expertise in Romanian water projects: Case study 'Room for the River in Cat's bend, Romania'. CE\&M research report 2011R001/WEM-001, ISSN 1586-4652, University of Twente, Enschede, the Netherlands. Available: http://doc.utwente.nl/77883/

Vinke-de Kruijf, J. (2009). Dutch expertise in Romanian water projects: retrospective case study 'Teleorman Flood Risk Management Pilot Project'. CE\&M research report 2009R-004/WEM-004, ISSN 1568-4652, University of Twente, Enschede, the Netherlands. Available: http://doc.utwente.n1/77884/

Vinke-de Kruijf, J. (2009). Applying Dutch Water Expertise Abroad: How to Contribute Effectively in the Romanian Context. Theoretical Framework. CE\&M research report 2009R-002/WEM-002, University of Twente, Enschede, the Netherlands. Available: http://doc.utwente.nl/77885/

De Kruijf, J. (2007). Problem structuring in interactive decision-making processes: How interaction, problem perceptions and knowledge contribute to a joint formulation of a 
problem and its solutions, MSc thesis, University of Twente, Enschede, The Netherlands. Available: http://essay.utwente.nl/524/

\section{Other publications}

Vinke-de Kruijf, J., Van Peppen, P., Ottow, B., Sannen, A., \& Udo, J. (forthcoming in 2013). How to facilitate the effective transfer of knowledge in international water projects: Lessons from Dutch research and practice. The Hague, the Netherlands: Partners voor Water.

Vinke-de Kruijf, J., Bressers, J. T. A., Hulscher, S.J.H.M., Augustijn, D. C. M. (2012), The challenges of transferring knowledge: Experiences from Romania. Water Governance, 2(1), 63-70.

Vinke-de Kruijf, J. (2009), Export van Nederlands waterbeheer: onderzoek naar de toepassing van Nederlandse expertise in Roemeense waterprojecten. Conceptueel, 18(5), 14-17 (in Dutch). Available: http://doc.utwente.nl/77303/ 